Júlia Rosseti Picinin Arruda Vieira

\title{
TRANSMISSÃO DA PROPRIEDADE IMÓVEL PELO REGISTRO DO TÍTULO E SEGURANÇA JURÍDICA: UM ESTUDO DE HISTÓRIA DO DIREITO BRASILEIRO.
}

Dissertação de Mestrado Realizada sob a orientação do Professor Titular Ignácio Maria Poveda Velasco, do Departamento de Direito Civil - Área de História do Direito - da Faculdade de Direito da Universidade de São Paulo. 


\section{Júlia Rosseti Picinin Arruda VieIRA}

\section{TRANSMISSÃO DA PROPRIEDADE IMÓVEL PELO REGISTRO DO TÍTULO E SEGURANÇA JURÍDICA: UM ESTUDO DE HISTÓRIA DO DIREITO BRASILEIRO.}

\footnotetext{
DisSERTAÇÃo DE MESTRAdo PARA A OBTENÇÃO DO TÍTULO DE MESTRE PELO DEPARTAMENTO DE DIREITO CIVIL - ÁREA DE HISTÓRIA DO DIREITO - DA faculdade de direito da Universidade de São Paulo.
}

Orientador: Professor titular Ignácio Maria Poveda Velasco.

Universidade de São Paulo

2009

Universidade de São Paulo 
Departamento de Direito Civil

\section{BANCA EXAMINADORA}

Presidente e Orientador

$1^{\circ}$ Examinador

$2^{\circ}$ Examinador

São Paulo,__ de ___ de 2009.

Aos meus queridos pais, pela confiança e apoio. 
Agradecimentos 
Ao Prof.Titular Ignácio Maria Poveda Velasco,

Pelos ensinamentos e constante incentivo à pesquisa.

À FAPeSP - Fundação de Amparo À Pesquisa do Estado de São Paulo,

Pela ajuda financeira em tempos difíceis.

"A propriedade é um direito, cujo conhecimento a todos interessa, não apenas para ser respeitada, mas em bem da ordem pública, interessada na segurança do direito em geral. E para tal segurança é indispensável que todos conheçam ou possam conhecer a quem esse direito pertence" 
Lysippo Garcia

\section{Resumo}


VIEIRA, Júlia Rosseti Picinin Arruda. Transmissão da propriedade imóvel pelo registro do título e segurança jurídica: um estudo de história do direito brasileiro. 2009.234f. Dissertação (Mestrado em Direito). Universidade de São Paulo, Faculdade de Direito, Programa de Pós-Graduação em Direito Civil, São Paulo, 2009.

O presente trabalho tem como objetivo estudar a evolução da disciplina da transmissão da propriedade imóvel pelo registro do título no direito brasileiro, relacionando-a com as seguranças do direito de crédito, do direito de propriedade e do comércio. O estudo, ao percorrer o período entre a Lei de Terras de 1850 e o Código Civil de 2002, constrói uma intrínseca relação entre as necessidades políticas, econômicas e sociais e as previsões do direito sobre a matéria em cada fase temporal. Com base em contextualizações históricas, legislações e doutrinas jurídicas, a dissertação busca demonstrar, que a normatização do modo de transferir a propriedade imóvel pelo registro do título no Brasil, decorreu do interesse, em momentos distintos, em proporcionar segurança ao crédito, ao direito de propriedade e ao comércio.

Termos de indexação: transmissão da propriedade imóvel, registro de imóveis, segurança jurídica, história do direito, título para a transferência da propriedade imóvel.

\section{Résumé}

VIEIRA, Júlia Rosseti Picinin Arruda. Transmission de la propriété immeuble par le registre du titre et sécurité juridique: une étude de l'histoire du droit brésilien. 2009. 234f. Dissertation (Master en Droit). 
Universidade de São Paulo, Faculdade de Direito, Programa de Pós-Graduação em Direito Civil, São Paulo, 2009.

Ce travail a pour but d'étudier l'évolution de la discipline de la transmission de propriété immeuble par le registre du titre dans le droit brésilien, en la rapportant aux sécurités du droit du crédit, du droit de propriété et du commerce. L' étude dans son parcours entre la Loi des Terres de 1850 et le Code Civile de 2002, construit un intrinsèque lien entre les nécessités politiques, économiques et sociales el les prévisions du droit sur la matière dans chaque phase temporelle. Sur les fondements des contextes historiques, des législations et des doctrines juridiques, la dissertation cherche démontrer que la mise un place des normes de la façon de trasférer la propriété immeuble par le registre du titre au Brésil, a decoulé de l'envie, dans de différents moments, d'offrir de la sécurité du crédit, au droit de propriété et au commerce.

Mots-clés: transmission de la propriété immeuble, registre d'immeubles, sécurité juridique, historique du droit, titre pour la transmission de propriété immeuble.

\section{SUMÁRIO}

1 INTRODUÇ̃̃̃ 
2 Tempos de Insegurança: RegularizaÇÃo da transmissão da PROPRIEDAdE IMÓVEl COMO CONSEQÜÊNCIA DA $\begin{array}{llllll}\text { BUSCA } & \text { PELA } & \text { SEGURANÇA } & \text { JURÍDICA } & \text { DO } & \text { DIREITO }\end{array}$

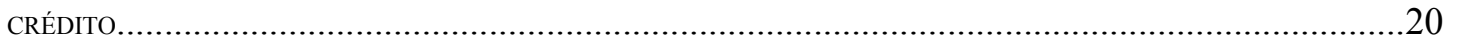

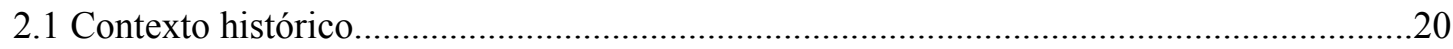

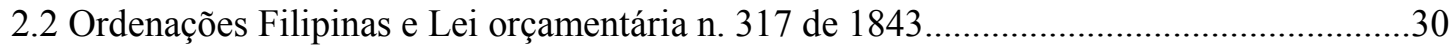

2.3 Lei n. 601 de 1850: Registro do Vigário..............................................................................

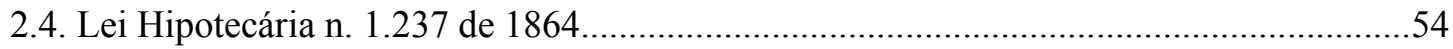

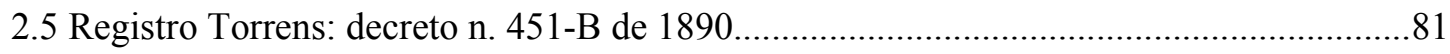

3 Seggurança jurídica do direito de propriedade x Segurança JuRídica do Comércio: posição do direito BRASILEIRO .94

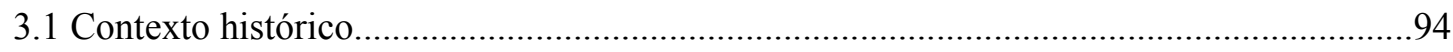

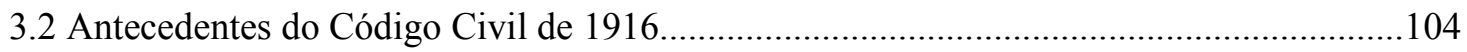

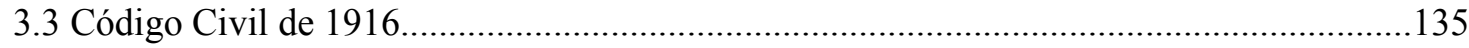

3.4 Primeiros anos de vigência do Código Civil: correções e complementações.......................155

4 SEgURANÇA JURÍDICA DO DIREITO DE PROPRIEDADE: A BUSCA PELA CORRESPONDÊNCIA ENTRE A REALIDADE FÁTICA E A REALIDADE JURÍDICA (ASSENTO REGISTRAL) .................................. 166

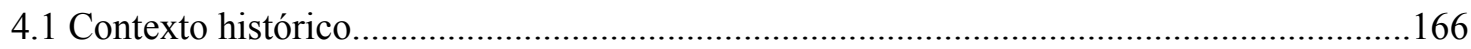

4.2 Antecedentes da lei n. 6.015 de 1973: Lei de Registros Públicos.....................................174

4.3 Lei de Registros Públicos: a instituição da matrícula...........................................................191

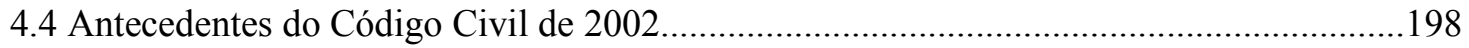

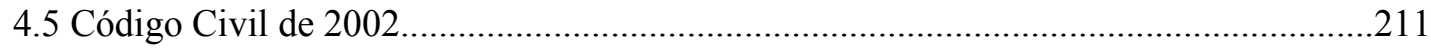

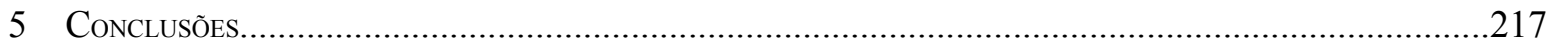

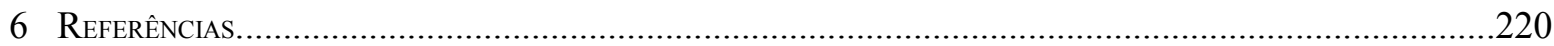




\section{INTRODUÇÃO ${ }^{1}$}

O direito de propriedade imóvel e conseqüentemente sua transmissão é uma das matérias do Direito Civil sobre as quais é difícil legislar, não só por envolver uma série de particularidades, como, por exemplo, o sistema de registro imobiliário ${ }^{2}$ que deve englobá-lo, mas principalmente pelas seguranças que deve garantir.

\footnotetext{
${ }^{1}$ Para a apresentação formal da dissertação, foram utilizadas as normas definidas pela Associação de Normas Técnicas Brasileiras (ABNT). Nas hipóteses em que a ABNT não faz previsão, as notas de rodapé e a referência foram elaboradas de maneira coerente com as demais determinações. Uma nota de rodapé explicativa indicará todas as vezes que isso ocorrer ao longo do trabalho.

${ }^{2}$ Conjunto de normas jurídicas que regulam as modificações jurídico-reais de imóveis, com o fim de proporcionar publicidade, autenticidade, segurança e eficácia aos atos jurídicos.
} 
Uma legislação bem elaborada acerca da transmissão da propriedade imóvel inter vivos (que desde o Código Civil de 1916 é especificada como a realizada "pelo registro do título") deve ter como foco a segurança jurídica e a segurança do comércio, de maneira a permitir que o homem planeje com antecedência e responsabilidade sua vida.

Atualmente, a transferência da titularidade de determinado bem ocorre por meio do registro de instrumento particular, escritura pública ou título judicial em livro específico na Serventia de Registro de Imóveis competente (livro 2 - Registro Geral - art. 176 da lei n. 6015 de 1973). A exigência do registro para a transmissão visa garantir, em um primeiro momento, a segurança do direito de propriedade e, em seguida, a do comércio e do crédito. No entanto, nem sempre a modificação do proprietário do imóvel no Brasil ocorreu por meio do registro do título, nem mesmo ela conseguiu assegurar a estabilidade jurídica e comercial esperada.

Estudando o histórico da transmissão da propriedade imóvel no Brasil desde o século XIX, quando ainda eram aplicadas as Ordenações Filipinas, parece que por muito tempo bastou unicamente a tradição para a transferência da propriedade imóvel. Com o tempo, ao buscar segurança nas relações jurídicas envolvendo bens imóveis, o legislador brasileiro abordou, em períodos diversos, três seguranças distintas. Inclusive, a regulamentação da transmissão da propriedade imóvel inter vivos veio como conseqüência da procura pela concretização de outros objetivos como, por exemplo, o de permitir a hipoteca de imóveis. ${ }^{3} \mathrm{Na}$ dissertação, esse período foi denominado de "Tempos de insegurança", justamente pelo fato de a segurança da transmissão não estar garantida, já que importava unicamente o registro geral das hipotecas.

\footnotetext{
3 TROPLONG ensinava que o processo tinha sido inverso no direito romano, ou seja, primeiro ocorreu a regulamentação da transmissão de bens imóveis, depois foi utilizada a estrutura já existente para a proteção do crédito. "Nada, porém mais estranho ás idéas de credito, do qual os creadores primitivos do direito romano não tiveram a mínima preoccupação. É mistér uma sociedade já avançada para cogitar disto, e quando os romanos chegaram ao ponto em que o movimento das relações sociaes põe em jogo o interesse dos terceiros, encontraram todo um systema de translação da propriedade anteriormente desenvolvido, sob outras influencias e independentemente desse interesse. O credito pôde sem dúvida delle aproveitar-se numa certa medida, mas não foi por causa delle que originariamente se introduziram no direito as formalidades exteriores, que eram a alma desse systema". SÁ PEREIRA, Virgilio de. Direito das Cousas. Art. 524-678. In: LaCERDA, Paulo de. Manual do Código Civil Brasileiro. Rio de Janeiro: Jacintho Ribeiro dos Santos, 1924, p. 111/vol.VIII. Para evitar repetições futuras, deixa-se esclarecido que ao longo do trabalho todos os trechos transcritos foram fiéis à redação feita pelos respectivos autores. Assim diversas vezes o português utilizado não seguirá as regras gramaticais vigentes hoje.
} 
Dessa maneira, em um primeiro momento o centro das atenções foi a segurança jurídica do crédito garantido por um bem imóvel. Depois vieram as discussões doutrinárias acerca das seguranças do comércio e do direito de propriedade. Por fim, a busca incessante por conciliar as três seguranças jurídicas, conciliação esta fundamental para o fortalecimento das instituições civis e da economia.

A transmissão da propriedade imóvel só se tornou o foco dos debates, na ocasião da elaboração do Código Civil de 1916, em virtude do posicionamento divergente de vários autores acerca do sistema imobiliário que deveria ser empregado no Brasil, defendendo uns a filiação ao sistema germânico, outros ao francês, ou ainda propugnando pela adoção de um novo regime. Contudo, como a modificação jurídico-patrimonial está diretamente relacionada à segurança do crédito, do comércio e do direito de propriedade, nada mais razoável que estudar a evolução da transmissão da propriedade imóvel por meio destas. Afinal, como se demonstrará ao longo da pesquisa, essa relação é intrínseca, já que a regulamentação da transferência de domínio de bem imóvel pelo registro do título no Brasil surgiu como conseqüência da necessidade de se garantir as seguranças acima enumeradas.

Assim sendo, é fundamental que se determine com precisão o significado que este estudo atribuiu a cada uma das três seguranças jurídicas envolvidas na transmissão da propriedade imóvel no Brasil independente, as quais serão abordadas ao longo desta dissertação, quando do estudo histórico-jurídico da transmissão da propriedade imóvel inter vivos.

Segundo José Joaquim Gomes Canotilno ${ }^{4}$, os elementos fundamentais do Estado de Direito são os princípios da segurança jurídica e da confiança legítima. Por meio deles o Estado procura garantir um mínimo de certeza às pessoas quanto a seus direitos e às expectativas juridicamente criadas, proporcionando a toda sociedade a confiança na tutela jurídica. Os princípios da segurança jurídica e da confiança legítima estão totalmente associados, podendo-se mesmo dizer que este é um subprincípio ou uma espécie daquele. Assim, em geral, a segurança do direito está ligada aos elementos objetivos da ordem jurídica (garantia de estabilidade jurídica, segurança de orientação e realização do direito) e à proteção

\footnotetext{
${ }^{4}$ Ao longo da dissertação, quando o autor for citado pela primeira vez, constará seu nome e prenome. Nos demais casos, apenas o nome pelo qual ele é conhecido no mundo jurídico.
} 
da confiança legítima aos elementos subjetivos da segurança (calculabilidade e previsibilidade dos indivíduos em relação aos efeitos jurídicos dos atos dos poderes públicos). ${ }^{5}$

Considerando a confiança legítima uma espécie da segurança jurídica, afirma-se que o cumprimento do princípio da segurança exige: clareza, racionalidade e transparência na ação estatal. Para participar de relações jurídicas, o indivíduo acredita na manutenção das normas vigentes, confiando em que elas sejam cumpridas e, portanto, que a atuação estatal seja totalmente previsível.

Conforme os ensinamentos de CANOTILHO, para a obtenção da segurança jurídica no relativo a atos normativos, exige-se a precisão das normas jurídicas, ou seja, a sua necessária configuração material e formal em termos lingüisticamente claros, compreensíveis e não contraditórios. Essa precisão é composta de dois elementos fundamentais: a) clareza da norma, sem a qual fica comprometida a interpretação, dificultando a obtenção de uma solução jurídica para o problema concreto, b) normas exatas, sem as quais não será possível fundamentar situações do cidadão favoráveis ou contrárias ao ordenamento jurídico, protegendo seus direitos e interesses. Não sendo a norma precisa o bastante, sua utilização será evitada pela própria Administração, já que a aplicação possivelmente trará inúmeros conflitos judiciais. ${ }^{6}$

A segurança jurídica será analisada ao longo do trabalho sobre três aspectos: como segurança jurídica do direito de crédito, do direito de propriedade e do comércio.

Na segurança jurídica do direito crédito, o objetivo é assegurar o crédito garantido por um bem imóvel. ${ }^{7}$ Em outras palavras, o ordenamento certifica o credor que em caso de inadimplemento da obrigação, o pagamento da dívida e das despesas de cobrança será feito pela quantia obtida com a venda do imóvel hipotecado.

Na segurança jurídica do direito de propriedade, o ordenamento jurídico assegura ao proprietário do bem o seu direito sobre ele, mesmo que haja algum vício na correspondência entre a realidade jurídica e os livros registrais, que leve terceiro de boa-fé a

\footnotetext{
${ }^{5}$ Direito Constitucional e Teoria da Constituição. Coimbra: Almedina, 1998. p. 250.

${ }^{6}$ Direito Constitucional e Teoria da Constituição. Coimbra: Almedina, 1998. p. 250.

${ }^{7}$ A fim de que o objeto do trabalho não fique muito extenso, apenas a garantia real do credito feita por bens imóveis será estudada.
} 
adquirir, em conformidade com a lei, o mesmo imóvel, porém de falso proprietário (exemplo: a escritura pública ou contrato particular de transmissão foram fraudados).

Já a segurança jurídica do comércio é entendida como a confiança que as pessoas devem depositar nas transações jurídico-patrimoniais. O indivíduo busca a concretização dessas transações de forma harmoniosa, sem que seja prejudicado por circunstâncias para ele, adquirente, desconhecidas. O intento é adquirir o bem com a certeza de que ele permanecerá em sua esfera de poder até uma futura venda, sem qualquer gasto suplementar (como por exemplo, de um litígio judicial). A crença no comércio é fundamental para que haja um mercado competitivo e próspero. Para José Soriano de Souza Neto, é justamente a contraposição entre a segurança do direito de propriedade e a segurança do comércio que aparece como problemática de difícil solução pelo legislador, afinal, como será visto adiante, não se pode obter uma senão com o sacrifício da outra. ${ }^{8}$

Esclarecido o sentido ofertado a cada termo, chega o momento de relacioná-los com a transmissão da propriedade imóvel pelo registro do título.

Ao se falar em transferência de bem imóvel, o enfoque da segurança pode variar de acordo com as necessidades econômico-sociais da época. Nos primeiros anos do Brasil pósindependência, o contexto histórico exigia uma maior atenção ao direito de garantia real do crédito, já que ele passou a ser importante para o desenvolvimento da agricultura por permitir a circulação dos títulos de propriedade, facilitando a transmissão imóvel e conseqüentemente assegurando o pagamento de vultosos empréstimos.

Para que o ordenamento assegure sem surpresas um imóvel como garantia por meio do instituto da hipoteca é indispensável que a propriedade esteja determinada e que a modificação jurídico-real esteja definida. ${ }^{9}$ Em outras palavras, um bom começo seria regulamentar a transmissão da propriedade imóvel, estabelecendo a qualificação de seu proprietário e os limites dessa propriedade. Tomadas essas precauções, é possível diminuir os custos da transação (já que havendo uma maior certeza quanto à titularidade da propriedade adquirida, o litígio judicial torna-se algo mais remoto) e das taxas de empréstimos (afinal, o

\footnotetext{
${ }^{8}$ Publicidade Material do Registro Imobiliário: efeitos da transcrição. Recife: [s.d.], 1940. p. 9.

${ }^{9}$ Freitas, Augusto Teixeira. Consolidação das Leis Civis. Rio de Janeiro: Typographia Universal de Laemmert, 1865. p. CXLV.
} 
credor tem maior garantia para o caso de inadimplemento, pois acredita que não perderá o dinheiro investido, uma vez que a execução real é certa). Com transmissões e taxas niveladas a valores mais baixos, há aumento nas relações comerciais e, como resultado, maiores investimentos e crescimento econômico.

Portanto, é difícil pensar em um registro de hipotecas sem que haja um registro de bens imóveis, no qual conste sua titularidade, as transmissões e ônus ocorridos ao longo do tempo. No entanto, os legisladores brasileiros só perceberam essa intrínseca relação, quando o dispositivo da Lei Orçamentária n. 317 de 1843 e os de seu regulamento, decreto n. 482 de 1846, não tiveram o efeito jurídico e econômico esperado. Essas normas regularam o registro de hipotecas sem, contudo, fazer menção à transcrição dos títulos. Assim, foi preciso a promulgação de uma nova lei que atendesse às necessidades de uma sociedade, em que o comércio passava a ser intenso e o valor da propriedade imóvel aumentava.

Foi quando surgiu a lei n. 1.237 de 1864, defendida pelo Conselheiro Nabuco, para tentar solucionar os problemas não resolvidos pela Lei Orçamentária e seu regulamento. ${ }^{10} \mathrm{~A}$ Lei Hipotecária de 1864 deu um novo rumo à constituição de hipoteca, fomentando o uso do direito de garantia, ao instituir a transcrição de todos os títulos para transmissão dos imóveis por atos inter vivos em registro público e ao dispor que a transferência do imóvel só se operava a respeito de terceiros, com a transcrição e a partir de sua data. Pelo que tudo parece, a previsão da transcrição rompeu com o direito anterior que dispunha ser a tradição suficiente para a aquisição da propriedade ${ }^{11}$.

Diante dessas considerações, fica fácil entender porque foi dito que a regulamentação da transferência da propriedade imóvel decorreu da preocupação com o direito de garantia real e não do desejo de bem definir a maneira de modificar a titularidade desse bem.

${ }^{10}$ Como será estudado no item 2.4, o projeto de reforma da Lei Hipotecária foi apresentado por um grupo de deputados liderados por Ignácio Joaquim Barbosa à Câmara dos Srs. Deputados em 1853. Nabuco de Araújo, membro da comissão especial nomeada para analisar o trabalho, passou a defender a reforma, propondo a criação de um registro dos "atos translativos da propriedade imóvel".

${ }^{11}$ Como será melhor compreendido no item 2.2, o modo de aquisição da propriedade imóvel inter vivos previsto nas Ordenações Filipinas será analisado indiretamente por meio das obras de autores que estudaram o tema. Para que fosse possível afirmar (com certeza) que a tradição era suficiente para a aquisição da propriedade imóvel no Brasil colônia, o ideal seria que as Ordenações fossem lidas minuciosamente, trabalho que não foi objeto desta dissertação. 
Apesar da inovação trazidas pela Lei Hipotecária de 1864, ela se mostrou incompleta já que não previa a transcrição das transmissões causa mortis e de atos judiciais, impedindo a formação de uma cadeia de titularidade nos livros registrais.

Em 1890, diante da necessidade de adotar um sistema registral que acabasse com a falibilidade e incerteza da propriedade territorial, surgiu o Registro Torrens, que, apesar de garantir a segurança do crédito e do comércio, não se popularizou pelo fato de exigir um procedimento longo e oneroso. ${ }^{12}$

Com a elaboração do Código Civil de 1916, discutiu-se mais uma vez a necessidade de adotar um sistema registral, que além de garantir a segurança do crédito, do direito de propriedade e do comércio, estivesse ao alcance de todo público (um processo de registro simples e acessível).

Se a legislação conseguisse atender todas essa exigências, geraria reflexos sensíveis na sociedade e na economia. Uma transação imobiliária é um importante mecanismo de alocação de recursos. No entanto, ela depende de que aquele que negocia tenha a propriedade exclusiva e livre sobre o objeto da troca, pois, caso contrário, o custo da negociação se encarece. Em outras palavras, as transações de bens e direitos devem ocorrer com celeridade e eficácia, e para isso é indispensável que haja certeza da titularidade do bem e que a modificação patrimonial faça do adquirente o verdadeiro proprietário. Haverá menor custo de transação na medida em que essas precauções dispensam gastos de litígios ou vigilância, não exigindo definição judicial do direito. ${ }^{13}$

Entretanto, um esforço pessoal de busca não é o bastante para se descobrir a situação jurídica do imóvel, que envolve a titularidade, os encargos que o oneram e outros direitos que recaem sobre ele. Na realidade, é necessária uma instituição que forneça todas essas informações, e nesse caso destaca-se o registro imobiliário, hipótese em que seu conceito

${ }^{12}$ Essas características negativas que levaram ao desuso do Registro Torrens decorreram da exigência da lei de levantamento topográfico (inclusive com planta, memorial descritivo), despacho de juiz togado, publicação de editais, decurso de prazo para a impugnação de terceiros e outros. Como as despesas são suportadas pelo adquirente e o processo judicial é demorado, até hoje o Registro Torrens é pouco utilizado, apesar de previsto facultativamente para imóveis rurais. O Registro Torrens será analisado em diversos pontos do trabalho, sendo o item 2.5 totalmente dedicado a ele.

${ }^{13}$ Guerreiro, José Augusto Guimarães Mouteira. O Registro Imobiliário. Necessário instrumento do progresso econômico-social. Revista de Direito Imobiliário, São Paulo, n.45, ano 21, p. 87 e 88, 1998. 
aproxima-se de um cadastro real. Com efeito, registrar a transmissão é apenas a parte inicial do indispensável para uma completa segurança do comércio, sendo também necessário o registro dos encargos e outros direitos sobre o imóvel.

Não sendo a legislação completa o bastante, o legislador terá que optar pela segurança do comércio (que com maior precisão garantirá a segurança do crédito) ou pela segurança do direito de propriedade.

Se o sistema registrário preza pela segurança do comércio, está seguro o terceiro de boa-fé que confia nas informações contidas nos livros fundiários, mesmo no caso de fraude (exemplo: terceiro de boa-fé adquire imóvel de pessoa que, apesar de estar inscrita no livro, não é proprietária. Descoberta a fraude, o comprador tem direito ao bem e o real proprietário obtém unicamente uma indenização daquele que o vendeu indevidamente). Protegido o direito do terceiro de boa-fé, fica desprotegido o direito de propriedade do titular do bem, vítima de alguma fraude ou confusão do oficial. Dessa feita, não havendo a total correção do livro registral, a segurança jurídica da propriedade e a segurança do comércio contrapõem-se, já que não se pode obter uma sem a renúncia da outra.

Já o ordenamento, que enfatiza a segurança do direito de propriedade, possibilita ao real proprietário o direito sobre seu imóvel, mesmo que não havendo correspondência entre a realidade jurídica e os dados contidos no registro, alguém de boa-fé adquira-o de um falso senhor do bem.

É claro, que a esperança de todos os países que adotam o sistema com cadastro, é que este traga dados corretos e atualizados sobre o imóvel e seu titular, para que não haja necessidade de prevalecer uma segurança sobre a outra. No entanto, apesar das aspirações, não é o que normalmente acontece.

No direito brasileiro, a primeira tentativa de se obter um cadastro imobiliário (que futuramente pudesse vir a garantir a segurança do direito de propriedade e do comércio) ocorreu com a promulgação da Lei n. 6015, de 1973, que instituiu a matrícula e sua obrigatoriedade. A matrícula é o instrumento que individualiza a propriedade imobiliária, determinando suas dimensões e limites e qualificando seu proprietário. Como após 30 anos da 
promulgação da lei, ainda eram muitos os imóveis sem matrícula, o que tornava longínqua a conciliação entre a segurança do direito de propriedade e do comércio, o legislador brasileiro buscou uma solução alternativa por meio do usucapião do parágrafo único do artigo 1.242 do Código Civil de 2002.

A partir de então, a proteção à segurança do direito de propriedade passou a preponderar sobre a segurança do comércio por um determinado período, ou seja, passados os cinco anos e cumpridos os requisitos do usucapião do parágrafo único do artigo 1.242, o ordenamento passa a garantir a segurança do comércio.

Por fim, destaca-se que além da matrícula e do instituto do usucapião, tiveram papel importante na procura pela presença das diversas seguranças na transmissão da propriedade imóvel pelo registro do título, o surgimento de alguns princípios basilares do sistema registral comum (que se contrapõe ao Sistema Torrens) como a publicidade formal (lei $\mathrm{n}^{\circ} 1.237$ de 1864), a especialidade (instituída pelo dec. n. 169-A de 1890) e a continuidade (dec. n. 18.542 de 1928). ${ }^{14}$

Apresentados os principais tópicos que serão desenvolvidos na dissertação, resta indicar que o presente estudo, focado na transmissão da propriedade imóvel inter vivos e nas diversas seguranças, será feito sobre o prisma da história do direito.

Estudar o tema pela história do direito parece ser o meio mais apropriado por permitir uma análise panorâmica da relação entre as necessidades econômico-politico-sociais e a incessante busca do legislador, ao longo dos séculos XIX e XX, para atendê-las. A escolha desse período temporal, mais especificamente da Lei de Terras de 1850, a lei 10.931 de 2004, justifica-se na medida em que se verifica a partir do século XIX, a mudança de uma concepção tradicional para uma concepção moderna no tocante à propriedade, à política de terras e à mão-de-obra no Brasil.

A terra que por muito tempo foi domínio da Coroa, doada principalmente como recompensa a serviços prestados ao rei, significava prestígio social. Um prestígio que não só derivava do reconhecimento de altas qualidades do proprietário, mas também pelo controle

\footnotetext{
${ }^{14}$ Todos esses princípios serão estudados em momento oportuno.
} 
que este tinha sobre inúmeros escravos e homens livres (arrendatários e meeiros). Com a mudança de concepção, a terra passou a ser domínio público, adquirida por quem pudesse explorá-la com lucratividade e utilizando mão-de-obra livre (principalmente imigrante). O imóvel passou a ser uma mercadoria que proporcionava ao seu proprietário poder econômico. $^{15}$

Diante da mudança de concepção, a propriedade imóvel transformou-se em objeto de inúmeras transações comerciais e em garantia de empréstimos. Com isso, a busca pela segurança jurídica tornou-se incessante, alterando e aperfeiçoando inclusive a maneira de transmitir a propriedade imóvel por meio do registro do título.

Para isso, o estudo baseou-se principalmente na análise de textos legislativos (e obrigatoriamente nos debates que os antecederam) e na doutrina de cada período. No âmbito legislativo, o estudo da transmissão da propriedade imóvel pelo registro do título e as diversas seguranças que o envolvem inicia-se com as Ordenações Filipinas, justamente por ser a legislação sobre a qual recai a Lei de Terras (primeira lei referente à propriedade imóvel após o período de anomia denominado de extralegal ou de posses). Em seguida, analisa-se a matéria principalmente na lei n. 1.237 de 1864, decreto n. 451-B de 1890, Código Civil de 1916, Decreto 18.542 de 1928, Lei 6.015 de 1973 e Código Civil de 2002. No âmbito doutrinário, são objeto de estudo as obras de autores como o Conselheiro NABuco, TeixeIra de Freitas, Ruy Barbosa, Lafayette Pereira, Clóvis Beviláqua, Lysippo Garcia, Philadelpho Azevedo, Soriano Neto, Afrânio de Carvalho, entre outros. ${ }^{16}$

Ao final da dissertação, estando todos os pontos explorados, será possível visualizar o quadro completo da relação entre a transmissão da propriedade imóvel pelo registro do título e as três acepções da segurança jurídica no direito brasileiro dos séculos XIX e XX. Desse modo, espera-se que tal quadro contribua para o estudo de história do direito, facilitando futuras pesquisas sobre o tema.

\footnotetext{
${ }^{15}$ Costa, Emília Viotti da. Da Monarquia à República: momentos decisivos. $8^{\mathrm{a}}$ ed., São Paulo: Fundação Editora UNESP, 2007. p. 174.

${ }^{16}$ As obras utilizadas no presente estudo serão indicadas em momento oportuno.
} 


\section{TEMPOS DE INSEGURANÇA: REGULARIZAÇÃO DA TRANSMISSÃO DA PROPRIEDADE IMÓVEL COMO CONSEQÜÊNCIA DA BUSCA PELA SEgURANÇA JURÍdICA DO DIREITO DE CRÉDITO.}

\subsection{Contexto histórico ${ }^{17}$}

Não há como, no século XIX, escrever sobre a contextualização histórica da transmissão da propriedade imóvel e dessa forma sobre terras, sem discorrer sobre a mão de obra escrava e da imigração, isso porque os três elementos estiveram intrinsecamente ligados durante todo o período do Império, inclusive no Segundo Reinado, época em que se situa essa primeira parte do estudo.

Na realidade, mão de obra e política de terra são noções que sempre estão de alguma forma relacionadas, variando apenas com a fase de desenvolvimento econômico pelo qual o país está passando.

${ }^{17}$ Todos os contextos históricos desta dissertação serão fundamentados em um ou dois autores principais. $\mathrm{O}$ intuito é que o texto fique coerente, uma vez que há diferença significativa na interpretação dos estudiosos sobre alguns momentos históricos. 
No século XIX, o Brasil era aos poucos atingido pela expansão dos mercados e do sistema capitalista, que exigia uma reavaliação dos dois elementos acima. Gradativamente, a terra e o trabalho foram sendo assimilados à economia comercial e industrial. Tratava-se de um período de aumento populacional, migrações internas e internacionais, concentração da população nos centros urbanos, desenvolvimento da indústria, acúmulo de capitais e melhoramento dos meios de transporte. ${ }^{18}$

Para Laura Beck Varela o interesse do capitalismo comercial e industrial era utilizar a propriedade imobiliária como garantia de empréstimos, permitindo que as relações jurídicas reais deixassem de ser fundadas na obrigatoriedade de cultivo. Não importava que a terra fosse improdutiva, o importante era que ela estivesse delimitada e registrada, o que asseguraria possíveis empréstimos. ${ }^{19}$

Por mais que a obrigatoriedade do cultivo não fosse mais exigência das legislações de terra surgidas ao longo da segunda metade do século XIX, não há como negar que com a economia comercial e industrial, houve uma expansão das áreas cultivadas para fins comerciais e uma redução daquelas destinadas à agricultura de subsistência. Prova disso é que o Segundo Reinado, iniciado com a coroação de D. Pedro II, em 1840, após o conhecido golpe da maioridade, caracterizou-se como um período de intensa cooperação entre a Coroa e as oligarquias de fazendeiros de café. Inclusive, os ganhos obtidos pelo governo com o café foram fundamentais para reduzir a dívida da Coroa com os britânicos. ${ }^{20}$

A expansão do mercado intensificou o uso da terra e do trabalho escravo o que, em muitos casos, gerou a expulsão de arrendatários e meeiros e a expropriação das pequenas propriedades e das terras comunitárias. ${ }^{21}$

\footnotetext{
${ }^{18}$ Viotti da Costa, Emilia. Da Monarquia à República: momentos decisivos. $8^{\mathrm{a}}$ ed., São Paulo: Fundação Editora UNESP, 2007. p.171.

${ }^{19}$ Das Sesmarias à propriedade moderna: um estudo de história do direito brasileiro. Rio de Janeiro: Renovar, 2005. p. 6.

${ }^{20}$ Skidmore, Thomas E. Uma história do Brasil. São Paulo: Paz e Terra, 1998. p. 67.

${ }^{21}$ Viotti da Costa, Emília. Da Monarquia à República: momentos decisivos. $8^{\mathrm{a}}$ ed., São Paulo: Fundação Editora UNESP, 2007. p.172.
} 
A situação impunha, cada vez mais, o surgimento de uma legislação que regulasse a propriedade e solucionasse o problema da mão de obra até então predominantemente escrava.

A inquietação quanto à necessidade de elaborar uma legislação referente a estes dois temas, terra e trabalho, vinha do fato de que, com a Resolução de 17 de julho de 1822, o Sistema de Sesmarias, já pouco aplicado na prática, tinha sido formalmente encerrado. A partir de então, o país passou a viver um período de anomia no relativo a terra, prevalecendo as ocupações. Quanto ao trabalho, a situação era pior, já que ainda se utilizava mão de obra escrava e a pressão inglesa para a contratação de trabalhadores livres tornava-se cada dia mais enérgica.

Diante da importância da terra e do trabalho, é indispensável o estudo de cada um dos temas.

No relativo a terra, o regime de sesmarias foi transplantado para o Brasil por meio das Ordenações Manuelinas e Filipinas. Sua primeira manifestação na colônia ocorreu por meio da carta dada a Martim Afonso de Souza, em 20 de novembro de 1530, na qual o rei lhe permitia conceder sesmarias das terras que encontrasse a quem pudesse aproveitar. ${ }^{22}$

Segundo RuY CiRne Lima, entre procurar a administração indo até o governador, e depois até o rei, para obter uma concessão de sesmarias, ou apossar-se de um pedaço de terra e cultivá-lo, era provável que os colonizadores optassem pela segunda. ${ }^{23}$ Assim, por muito tempo, na colônia e mais tarde após a independência, a ocupação aparecia como a melhor ou mesmo única forma de ter acesso à propriedade imóvel.

Citando um relatório de Gonçalves Chaves $^{24}$ divulgado em 1822, Cirne Lima indicava que esse Sistema de Sesmarias mal aplicado trouxe como conseqüência para o país uma vasta área ocupada, em contraste com a pouquíssima população, poucas áreas livres

\footnotetext{
${ }^{22}$ Lima, Ruy Cirne. Pequena História Territorial do Brasil: Sesmarias e Terras Devolutas. $2^{\mathrm{a}}$ ed., Porto Alegre: Sulina, 1954. p. 32.

${ }^{23}$ Ibidem., p. 31, 32 e 37.

${ }^{24}$ Como não há previsão expressa na $\mathrm{ABNT}$, optou-se por escrever os nomes de todos os autores em caixa alta.
} 
possíveis de serem repartidas, grandes latifundiários, mas muitas famílias sem terra para cultivo e agricultura em atraso. ${ }^{25}$

Para Raymundo Faoro, a sesmaria deixou como herança senhores de terra com extensas fazendas que não cultivavam, nem permitiam que outros o fizessem. Ainda, lavradores meeiros e moradores de favor, vivendo da agricultura de subsistência e totalmente excluídos da agricultura de exportação. ${ }^{26}$

Para que esse quadro fosse alterado, era imprescindível que uma nova concepção da política de terras substituísse a tradicional, existente no país desde o século XVI.

Segundo Emília ViotTi da Costa, pela concepção tradicional, a terra era domínio da Coroa, que a transmitia por meio de doação àqueles que se mostrassem fiéis e prestativos ao rei, razão pela qual ser proprietário significava antes de tudo prestígio social, do qual derivava poder econômico. Como era o monarca que doava a terra, ele podia impor certas condições, como regular o uso e a ocupação, limitar o tamanho da área e estipular quantas concessões uma única pessoa poderia receber. ${ }^{27}$

Aos poucos, essa concepção tradicional foi substituída por uma noção moderna, transição apenas concluída no século XX. Pela concepção moderna, a terra passou a ser considerada domínio público, servindo o Estado unicamente como intermediador em sua aquisição. A terra tornou-se uma mercadoria, podendo ser adquirida por todo aquele que pudesse explorá-la com lucratividade e ser proprietário começou a representar poder econômico, do qual podia advir prestígio social. Sendo a terra uma mercadoria, coube ao proprietário estipular suas próprias condições. ${ }^{28}$

\footnotetext{
${ }^{25} \mathrm{O}$ autor define com as seguintes palavras o que foi o relatório e quem era Gonçalves Chaves "Memorias economopolíticas sobre a Administração Publica do Brasil, compostas no Rio Grande de S. Pedro do Sul e offerecidas aos Deputados do mesmo Brasil, por hum portuguez, residente no Brasil, há 16 annos; que professa viver só do seu trabalho, e deseja o bem da Nação, ainda com preferência a seu próprio". Pequena História Territorial do Brasil: Sesmarias e Terras Devolutas. 2aed., Porto Alegre: Sulina, 1954. p.42 e 43.

${ }^{26} \mathrm{O}$ autor ressaltava o fato de que, diferentemente do pequeno agricultor, o grande fazendeiro tinha a possibilidade de enviar seus descendentes para ocupar cargos públicos, caso a agricultura não prosperasse como esperado, diante de catástrofes naturais e econômicas. Os Donos do Poder; formação do patronato político brasileiro. Porto Alegre: Globo, 1958. p. 419.

${ }^{27}$ Da Monarquia à República: momentos decisivos. $8^{\mathrm{a}}$ ed., São Paulo: Fundação Editora UNESP, 2007. p. 174.

${ }^{28}$ Ibidem., mesma página.
} 
Já quanto à mão de obra escrava, as primeiras medidas relativas ao tráfico foram tomadas devido à pressão inglesa. A exigência britânica tinha tanto motivação moral e ideológica, pois era fruto da expansão de idéias iluministas, como também econômica. $\mathrm{O}$ fator econômico era explicado pela dificuldade que as colônias caribenhas britânicas passaram a ter para a obtenção de escravos, diante da proibição de seu comércio nos Estados Unidos, em 1807. Com a mão-de-obra escassa, os custos aumentaram, deixando as colônias pouco competitivas se comparadas a Cuba e ao Brasil. Para que o equilíbrio retornasse, seria fundamental que a escravidão fosse abolida nesses países. ${ }^{29}$

Apesar do Brasil assinar tratados de abolição do tráfico negreiro com a Inglaterra (com quem estava endividado), eles não foram implementados até 1850, quando o Parlamento Brasileiro aprovou lei proibindo o comércio de escravos. A demora foi resultado da outra pressão que o governo brasileiro sofria, a dos fazendeiros de café e outros proprietários de terra, que acreditavam que, com o fim do uso da mão-de-obra escrava, haveria um colapso na agricultura. $^{30}$

Foi apenas em 1850, como resultado da pressão inglesa, que o tráfico de escravos foi proibido, coincidindo com um período de grande expansão do café. $^{31}$ Nessas circunstâncias, os fazendeiros tiveram que recorrer ao tráfico interno de escravos, comprandoos de áreas decadentes do país. Mas também, começaram a se interessar pela possibilidade de trazer mão de obra de países europeus. ${ }^{32}$ Assim, como será visto no item 2.3, não foi por acaso que a Lei de Terras de 1850 foi decretada no mesmo ano da lei que aboliu o comércio de escravos.

\footnotetext{
${ }^{29}$ SKIDMORE, Thomas E. Uma história do Brasil. São Paulo: Paz e Terra, 1998. p.78 e 79.

${ }^{30}$ Skidmore, Thomas E. Uma história do Brasil. São Paulo: Paz e Terra, 1998. p. 80.

${ }^{31}$ Como motivos para a aprovação pelo Parlamento Brasileiro da proibição do comércio de escravos, SKIDMORE aponta: a pressão naval inglesa, inclusive com ameaça à soberania brasileira, o medo da elite de não conseguir controlar os escravos (o receio do haitianismo, referência à rebelião de escravos ocorrida no Haiti, em 1790) e irrupções de febre amarela e cólera na década de 1840, atribuídas aos escravos recém-chegados. Ibidem., mesma página.

${ }^{32}$ Viotti da Costa, Emília. Da Monarquia à República: momentos decisivos. $8^{\text {a }}$ ed., São Paulo: Fundação Editora UNESP, 2007. p. 193.
} 
Com o aumento do ritmo cafeeiro ${ }^{33}$, ter crédito tornou-se uma necessidade maior do que ter a própria fazenda. O crédito era necessário, principalmente para a obtenção de mão de obra escrava, um investimento que oscilou de 1850 a 1886 entre 30 e $70 \%$ sobre o valor total da empresa. Até o solo com o tempo aumentou de preço, chegando a valer depois da grande expansão do café, dez vezes o valor original. ${ }^{34}$

Acontece que, ocorrida a proibição do tráfico, a tendência era que a obtenção de créditos se tornasse mais escassa. Afinal, até então, o crédito era fornecido pelos traficantes de escravos que parcelavam o valor de suas mercadorias, permitindo que o senhor de terras não gastasse todo seu capital no momento da compra. Em troca, cobrava altos juros, que anexados ao preço do escravo, eram por poucos percebidos. ${ }^{35}$

Assim, com o fim dos empréstimos inseridos na venda de escravos e a necessidade de mão de obra, os fazendeiros tiveram que procurar outra maneira de obter capital. No lugar do traficante, surgiu como principal intermediário entre eles e a cidade, a casa bancária. Diante do novo quadro, os fazendeiros viram um súbito aumento de seus ganhos, uma vez que os empréstimos eram concedidos a juros baixos. ${ }^{36}$

Quem não gostou da nova situação foram os antigos traficantes, que antes ficavam com grande parte do lucro do tráfico e com as altas taxas de juros. Como não conseguia concorrer com a eficiência de alocação de recursos dos bancos, essa classe criticava veementemente a nova sociedade empresária, utilizando seus contatos no parlamento, para que medidas contrárias aos banqueiros fossem tomadas. Por esse motivo, rapidamente foi aprovado o projeto de criação do banco nacional, que, futuramente, acabou levando ao fechamento das casas bancárias privadas. ${ }^{37}$

O banco oficial dificultava a obtenção de crédito, o que gerou a elevação das taxas de juros e a ampliação dos ganhos dos rentistas. Como a nova situação desestimulava o

${ }^{33}$ Segundo Murilo de Carvalho, já na década de 1840, o café passou a ser o principal produto de exportação do Brasil, ultrapassando até mesmo o açúcar. Perfis Brasileiros: D. Pedro II. São Paulo: Companhia das Letras, 2007. p. 42 e 138.

${ }^{34}$ Faoro, Raymundo. Os Donos do Poder; formação do patronato político brasileiro. Porto Alegre: Globo, 1958. p. 412.

${ }^{35}$ CALDEIRA, Jorge. Mauá: empresário do Império. São Paulo: Companhia das Letras, 1995. p. 242 e 273.

${ }^{36}$ CALDEIRA, Jorge. Mauá: empresário do Império. São Paulo: Companhia das Letras, 1995. p. 273.

${ }^{37}$ Ibidem., p. 301. 
investimento e aumentava o interesse pelo capital especulativo, só permaneciam no mercado de crédito aqueles que não tinham outra opção, ou seja, os fazendeiros de café. ${ }^{38}$

Só que essa tarefa de obter financiamento, na maioria das vezes, era realizada por intermediários, já que para o fazendeiro era difícil trabalhar no campo e ir com freqüência à cidade. Esses intermediários eram chamados de comissários, um comerciante que, na base da confiança, ligava a plantação e a exportação, arrumando financiamento, enviando mercadorias, comprando insumos para a fazenda e, por fim, adquirindo toda a safra. ${ }^{39}$

Para Jorge CAldeira, o comissário, ao fornecer créditos misturados com mercadoria, substituiu os traficantes como financiador da economia cafeeira, ficando com todo o lucro da lavoura. Ele conseguia essa proeza, porque o valor de tudo que comprava para os fazendeiros era somado e abatido quando da venda da safra, e recebia por essa tarefa altos juros. $^{40}$

Por mais que o lucro dos fazendeiros fosse pequeno, e ainda que desconfiassem da atuação do comissário, não tinham interesse em romper esse elo de confiança. Afinal, tinham a certeza de que sempre haveria crédito, já que o intermediário não arriscaria perder seu posto lucrativo. Dessa maneira, era mais interessante pagar caro pelo dinheiro, mas saber que ele jamais faltaria, mesmo nos momentos de necessidade, do que optar por baixos juros bancários e viver na dúvida de empréstimos futuros. ${ }^{41}$

Por isso se diz que por algum tempo, no Brasil imperial, não havia interesse de grande parte da sociedade no surgimento de leis que regulassem o crédito real. Como será visto nos itens seguintes, essa falta de preocupação em regulamentar direitos de garantia, como a hipoteca, vai levar também a uma incipiente legislação referente à transmissão da propriedade imóvel. Dessa maneira, é justamente por não haver interesse em organizar as terras no país ou o direito de garantia real, que é afastada a previsão de uma transmissão

\footnotetext{
${ }^{38}$ Ibidem., mesma página.

${ }^{39}$ Ibidem., p. 302.

${ }^{40} \mathrm{O}$ autor afirmava que os comissários "Disfarçavam a usura com mesuras: sempre que o fazendeiro ia ao Rio, cumulavam-no de atenções, alugavam boas carruagens, quebravam o galho dos filhos estudantes, arrumavam uma casa em Petrópolis para as férias da família”. Mauá: empresário do Império. São Paulo: Companhia das Letras, 1995. p. 302.

${ }^{41}$ Ibidem., p. 303.
} 
imobiliária inter vivos que trouxesse segurança ao crédito, ao direito de propriedade e ao comércio.

No entanto, com o passar do tempo, a necessidade de créditos em um comércio movimentado tornou-se cada vez mais evidente, não sendo suficientes medidas paliativas. Tal exigência levou deputados e senadores a discursarem e aprovarem projetos sobre a matéria, como o decreto n. 482 de 1846, regulando o artigo 35 da lei orçamentária de $1843 .{ }^{42}$

Além da dificuldade na obtenção de crédito, tornou-se cada vez mais difícil obter mão de obra escrava, o que fez com que alguns fazendeiros optassem por trazer imigrantes europeus para trabalharem como meeiros em fazendas de café. Os fazendeiros pagavam a passagem, prometiam emprego e boas condições de trabalho em troca do serviço na lavoura. De início, a iniciativa fracassou, provavelmente pela impossibilidade de conciliar os dois tipos de trabalho, o escravo e o livre, na mesma plantação. A maneira desumana pela qual os imigrantes eram tratados levou alguns países europeus a se manifestarem contrários à imigração para o Brasil. Como resultado, obteve-se a certeza de que para o uso de mão de obra livre prosperar, seria fundamental o fim do trabalho escravo. ${ }^{43}$

Diante do fracasso inicial da imigração, aqueles que se opunham à substituição de trabalhadores escravos por livres, acabaram intensificando seu discurso. ${ }^{44} \mathrm{Na}$ realidade, esses utilizavam qualquer argumento para desqualificar o uso de imigrantes na lavoura, mesmo que fosse o mais absurdo. ${ }^{45}$

Acontece que, com o passar do tempo, os próprios fazendeiros paulistas começaram a questionar se o uso de mão de obra livre não seria tão eficaz e mais barato que a escrava. Ademais, seria significativo para o país que o controle da mão de obra não

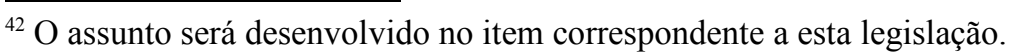

${ }^{43}$ Skidmore, Thomas E. Uma história do Brasil. São Paulo: Paz e Terra, 1998. p. 106.

${ }^{44}$ Ibidem., p. 77.

${ }^{45}$ Interessante a passagem contada por CALDEIRA em seu livro. Segundo o autor, as fazendas de Mauá diferenciavam-se totalmente das demais, já que elas tinham alto grau de eficiência. Utilizaram-se nas plantações os primeiros arados à vapor do país, e técnicos estrangeiros eram trazidos para dirigir a lavoura. A fim de provar a sua idéia de substituição dos escravos por trabalhadores contratados por tempo determinado, já que depois eles seriam liberados para trabalharem por conta própria, o empresário contratou coolies chineses. Ao invés da experiência de Mauá ser observada de perto, para que o sistema de substituição de escravos pudesse ser aproveitado, a Câmara dos Deputados criou uma comissão de inquérito para analisar se a inserção de trabalhadores asiáticos no país não traria conseqüências trágicas à formação do homem brasileiro, se não levaria à degeneração da raça. Mauá: empresário do Império. São Paulo: Companhia das Letras, 1995. p. 519. 
dependesse de um status legal, ou ainda, da sobrevivência econômica e que o domínio político não ficasse à mercê de uma instituição específica. ${ }^{46}$

Acresce-se a isso o fato de que, no final da década de 60 e início da 70, o movimento abolicionista começou a ganhar um apoio mais amplo, destacando-se figuras como Joaquim Nabuco, José do Patrocínio, André Rebouças, Luís da Gama e outros. Interessante como entre todos os abolicionistas, André Rebouças tenha sido o único a defender a necessidade da reforma da terra, ou seja, de perceber que os dois elementos, terra e trabalho, estavam intrinsecamente relacionados. ${ }^{47}$

Para este libertário, a propaganda abolicionista buscava além da abolição imediata e sem indenização, o fim do monopólio territorial das mãos da aristocracia rural, que ele chamava de landocracia. AndRÉ ReBouçAs acreditava que o escravismo, agravado pela concentração territorial, era o maior responsável pelo estrago da economia brasileira, impedindo o progresso da Pátria, daí a necessidade de medidas enérgicas que atacassem os dois problemas. As medidas deveriam ser distintas, já que o fim da escravidão não seria suficiente para eliminar os latifúndios. ${ }^{48}$

Outros fatores importantes na intensificação do apoio da sociedade ao movimento abolicionista foram: a percepção da elite de que o Brasil jamais seria visto no exterior como um país moderno, enquanto houvesse escravidão, e o mal estar entre políticos e militares, principalmente após a intensa participação dos negros na Guerra do Paraguai. ${ }^{49}$

Diante dessa gradativa mudança, foi cada vez maior o número de imigrantes que passaram a chegar ao Brasil para trabalhar na lavoura e substituir a mão de obra escrava. Todavia, eles foram introduzidos em grande número nas fazendas brasileiras apenas na década

\footnotetext{
${ }^{46}$ Skidmore, Thomas E. Uma história do Brasil. São Paulo: Paz e Terra, 1998. p. 106.

${ }^{47}$ Ibidem., mesma página.

${ }^{48}$ Para ANDRÉ Rebouças, não havia nada de mais injusto do que um trabalhar na terra e o outro gozar dos frutos desse trabalho, a terra deveria pertencer e quem nela trabalhasse. SAntos, Sydney M.G. dos. André Rebouças e seu tempo. Rio de Janeiro: Vozes Ltda, 1985. p. 470, 471 e 538.

${ }^{49}$ Skidmore, Thomas E. Uma história do Brasil. São Paulo: Paz e Terra, 1998. p. 99 e 106.
} 
de $1880{ }^{50}$ e principalmente após a abolição, quando chegaram grandes levas de italianos, espanhóis e portugueses. ${ }^{51}$

Interessante perceber como em nenhum momento, durante a ampla e longa discussão da necessidade de se obter trabalhadores para a agricultura brasileira, houve quem defendesse a utilização de negros libertos. Para Thomas E. Skidmore ${ }^{52}$ os motivos eram claros: a elite considerava o trabalhador não branco fisicamente inferior e incapaz de hábitos sérios de trabalho, era mais fácil controlar os imigrantes europeus: estes trariam as qualidades que os nordestinos não tinham e ajudariam a melhorar a linhagem ética do país. ${ }^{53}$

Muitos dos imigrantes europeus que vieram para o Brasil, ficaram pouco tempo no campo, mudando-se para a cidade na primeira oportunidade. Isso decorreu do fato de que muitos dos europeus que aqui chegavam nunca tinham sido empregados em fazendas, tendo no Velho Mundo trabalhado em fábricas, no comércio ou com serviços. E, mesmo aqueles que eram trabalhadores rurais, estavam acostumados com uma outra realidade, outro solo, clima, técnica de plantio, o que dificultava muito a integração. ${ }^{54}$ Apesar de todos esses empecilhos, os imigrantes solucionaram o problema principal da economia brasileira no momento, ou seja, a falta de trabalhadores.

Outro dado importante desse período foi a disseminação entre a elite brasileira de correntes ideológicas como o Positivismo e o Republicanismo, que levaram a proclamação da República em 1890.

\footnotetext{
${ }^{50}$ Viotti da Costa, Emília. Da Monarquia à República: momentos decisivos. $8^{\mathrm{a}}$ ed., São Paulo: Fundação Editora UNESP, 2007. p. 195.

${ }^{51}$ Segundo Boris Fausto entre 1887 e 1930 entraram no Brasil cerca de 3,8 milhões de estrangeiros. História do Brasil. $6^{a}$ ed., São Paulo: Universidade de São Paulo: Fundação para o desenvolvimento da Educação, 1999. p. 275.

${ }^{52}$ Uma história do Brasil. São Paulo: Paz e Terra, 1998. p. 106.

${ }^{53}$ Santos ressalta que André Rebouças não compartilhava essa visão depreciativa do trabalho do negro, pelo contrário, acreditava que ela não se justificava quando se observava que havia sido o escravo o responsável por tornar o Brasil império o maior produtor de café do mundo. André Rebouças e seu tempo. Rio de Janeiro: Vozes Ltda, 1985. p. 476.

${ }^{54}$ Sérgio Buarque de Holanda in prefácio na obra de Thomaz Davatz acentua que "A agricultura de tipo europeu era, sobretudo impraticável nos lugares incultos e remotos (...) não há talvez exagêro em declarar que os métodos bárbaros da agricultura indígena eram em alguns casos os que convinham". Davatz, Thomas. Memórias de um colono no Brasil. São Paulo: Martins Editora, 1972. p. XVI e XVIII.
} 
A teoria positivista agradou diversos seguimentos da população. Afinal, condenava a Monarquia, desejo da elite; defendia a separação do Estado e da Igreja, elogiada por estudantes, professores e militares; aspirava à incorporação do operariado à sociedade moderna e a adoção de políticas sociais pelo governo, o que melhorou a visão das classes operárias sobre a República. As propostas concretizar-se-iam por meio de um Executivo forte e intervencionista. ${ }^{55}$

Os militares foram o grupo social que mais se identificou com a versão positivista da sociedade e da República. O interessante era que para as teses positivistas, um governo militar seria um retrocesso. Mas, como no Brasil os militares tinham uma formação científica que se opunha à formação literária da elite civil, eles se identificavam com a doutrina positivista, uma vez que ela enfatizava a Ciência e o desenvolvimento industrial. Ocorreu assim, uma adaptação do ideal importado da Europa. ${ }^{56}$

Já quanto à difusão do republicanismo, para SKIDMORE ela ganhou força com dois acontecimentos: primeiramente, com o enfraquecimento político de D. Pedro II que, na época da Guerra do Paraguai, havia convocado um governo conservador apesar da maioria na Câmara dos Deputados ser liberal, gerando a crise de 1868. Em segundo lugar, porque a elite não se conformava com o fato dos Estados Unidos, um país republicano, ter passado por uma rápida industrialização, enquanto o Brasil, monárquico, mantinha-se agrário. ${ }^{57}$

Já para José Murilo de Carvalho, a grande protagonista do fim da monarquia no Brasil foi a Guerra do Paraguai. Afinal, o conflito elevou a dívida externa brasileira, gerou a crise de 1868, intensificou a luta pela abolição, provocou corporativismo militar e intensificou o republicanismo. ${ }^{58}$

No dia 15 de novembro de 1889, a tendência republicana acabou sendo concretizada, ocorrendo o fim do Segundo Reinado e o início da República. ${ }^{59}$

\footnotetext{
${ }^{55}$ Carvalho, José Murilo de. A formação das almas: o imaginário da República no Brasil. São Paulo: Companhia das Letras, 1990. p. 27.

${ }^{56}$ Carvalho, José Murilo de. A formação das almas: o imaginário da República no Brasil. São Paulo: Companhia das Letras, 1990. p. 27 e 38.

${ }^{57}$ Uma história do Brasil. São Paulo: Paz e Terra, 1998. p. 98 e 99.

${ }^{58}$ Perfis Brasileiros: D. Pedro II. São Paulo: Companhia das Letras, 2007. p. 124.

${ }^{59}$ Interessante o quadro que Murilo de Carvalho traça sobre o governo de D. Pedro II. Diz o autor: "Em quase meio século de reinado, D. Pedro II presidiu à solução dos grandes problemas que, quando ele subiu ao trono,
} 


\subsection{Ordenações Filipinas e Lei orÇamentária n. 317 de 1843}

Com a proclamação da Independência em 7 de setembro de 1822 e a aclamação de D. Pedro Imperador em 12 de outubro do mesmo ano, o Brasil tornou-se uma unidade política livre e independente. Dessa forma, o país deveria apresentar uma legislação própria, desassociada da portuguesa. No entanto, como não era possível substituir imediatamente a legislação em vigor com novas leis que satisfizessem as necessidades do novo Império, promulgou-se a lei de 20 de outubro de 1823, dispondo que continuariam em vigor na parte que não tinham sido revogadas entre outras legislações, as Ordenações Filipinas. ${ }^{60}$

As Ordenações Filipinas entraram em vigor em 11 de janeiro de 1603, no reinado de Felipe III (Felipe II de Portugal) da dinastia castelhana. Nada mais eram do que uma atualização das Ordenações Manuelinas, já que além de reunir seus dispositivos, incluíam a Coleção de Duarte Nunes Leão e as leis a ela posteriores. As Ordenações Filipinas foram aplicadas sem qualquer reforma até o advento do Código Civil, ou seja, 1867 em Portugal e 1917 no Brasil. ${ }^{61}$

Como as Ordenações Filipinas mantiveram-se em vigor no Brasil até 1917, não há como analisar qualquer instituto civil sem antes fazer uma breve análise de como era regulado por esse monumento legislativo, mesmo que atos normativos esparsos tenham alterado com o tempo as suas determinações.

ameaçavam a própria existência do país. À beira da fragmentação em 1840, o Brasil em 89 exibia poucos sinais de fratura. $\mathrm{O}$ tráfico fora extinto, e a escravidão fora abolida. $\mathrm{O}$ processo foi demasiado lento, mas até o fim, $\mathrm{o}$ imperador e os abolicionistas tiveram de enfrentar a resistência tenaz de proprietários e da maioria da representação nacional. A instabilidade política havia sido substituída pela consolidação do sistema representativo e pela hegemonia do governo civil, em nítido contraste com o que se passava em países vizinhos. $\mathrm{Na}$ política externa o Brasil definira com clareza e preservara seus interesses na região platina, e ganhara respeitabilidade diante da Europa e dos países americanos. Pessoalmente, o monarca conquistara o respeito internacional pela dignidade e patriotismo com que exercera o poder e pela proteção que dispensara às ciências e às letras. Muito ainda restava por fazer, sobretudo no campo da educação, da descentralização do poder, da formação do povo político. Como ele mesmo notou, tudo andava devagar demais no Brasil. Mas, posto que lentamente, estavam lançadas as bases para a construção do país". Ibidem., p. 221 e 222.

${ }^{60}$ Trípoli, César. História do Direito Brasileiro. Revista dos Tribunaes, São Paulo, vol. 2, p. 153, 1947.

${ }^{61}$ Poveda Velasco, Ignácio Maria. Ordenações do Reino de Portugal. Revista da Faculdade de Direito da Universidade de São Paulo, v.89, p. 24, 1994. 
Foi o que aconteceu com a transmissão de imóveis inter vivos que, por muitos anos após a Independência do Brasil, continuou a ser regrada pelas Ordenações Filipinas, sendo aos poucos, com o surgimento de leis esparsas, modificada.

Antes de tratar sobre a maneira como alguns autores vêm interpretando os dispositivos das Ordenações referentes à matéria, é importante que se faça uma pequena digressão.

Atualmente, a transmissão da propriedade imóvel inter vivos é ato complexo, envolvendo o título, em que as partes celebram o negócio jurídico e o registro na Serventia competente, momento em que a transferência concretiza-se. Assim, para examinar esta modificação jurídico-real é fundamental estudar o título e o registro, já que no sistema registrário atual, o registro é causal, estando sempre vinculado ao título translatício.

Por esse motivo, para que ao longo da pesquisa sejam analisadas as seguranças que norteavam a transmissão da propriedade imóvel pelo registro do título, será muitas vezes necessário analisar também o histórico do título. ${ }^{62}$ Feita esta pontual observação, passa-se para o estudo do primeiro monumento legislativo que tratou sobre a matéria da transmissão de bens imóveis inter vivos no Brasil.

Pelo que parece, nas Ordenações Filipinas, a transmissão da titularidade de bens móveis e imóveis ocorria por meio da tradição, não sendo exigida qualquer outra formalidade.

A tradição, como modo de adquirir domínio, consiste na entrega que o senhor de coisa corpórea, com animus de transferir o domínio, faz a outrem que deseja adquiri-la. ${ }^{63}$ É um modo derivado de aquisição de propriedade, ou seja, não cria o domínio, pressupõe sua existência e limita-se a transferi-lo.

Analisando o contrato de compra e venda, mais especificamente o Livro $4^{\circ}$, Título $\mathrm{V}, \S 1$ das Ordenações Filipinas, CÂNDIDo Mendes de Almeida concluía que para que o contrato

\footnotetext{
${ }^{62}$ No entanto, destaca-se que o objeto desta dissertação é a segurança do registro e não dos títulos de transmissão, assim sendo, a abordagem deste tema será realizada apenas de forma acessória, para complementar quando necessário o assunto principal da pesquisa.

${ }^{63}$ Pereira, Lafayette Rodrigues. Direito das Coisas. Rio de Janeiro: Jacintho Ribeiro dos Santos, [188?], p. 108/vol.1
} 
ficasse perfeito, era indispensável que o vendedor transferisse o domínio sobre a coisa ao comprador, quando este lhe entregasse o preço. ${ }^{64}$

Esse entendimento era reforçado pela interpretação que Virgílio de SÁ PereirA fazia da leitura do Título II desse mesmo Livro que afirmava:

“... tanto que o comprador e o vendedor são acordados na compra e venda de alguma certa cousa por certo preço, logo esse contracto é perfeito e acabado" 65

Segundo o autor, essa disposição não podia ser interpretada como se apenas o contrato transferisse a propriedade. O uso da expressão "perfeito e acabado" nada mais era do que influência do Corpus Iuris Civilis e cópia de seus brocardos jurídicos. ${ }^{66}$

Para SÁ Pereira a expressão não queria dizer "consumado". Na realidade, a transferência da propriedade dependia não só do acordo entre as partes, como também que suas intenções de transferir ou adquirir domínio fossem externadas pela tradição. Assim, apenas com a tradição da coisa o contrato consumava-se e ocorria a transferência da propriedade. Tal assertiva confirmava-se quando, ao analisar a continuação das Ordenações, percebia-se que caso o vendedor não entregasse a coisa ao comprador, cabia ação de perdas e danos (pessoal) e não a ação real de reivindicação, como ocorreria caso o simples acordo transferisse a propriedade. ${ }^{67}$

Dessa maneira, pelo que tudo indica da leitura da obra dos autores que se dedicaram (por meio da análise do contrato de compra e venda) ao estudo da transferência da propriedade imóvel nas Ordenações Filipinas, o direito brasileiro exigia para a transmissão do domínio a tradição da coisa.

Com a necessidade de um comércio cada vez mais dinâmico, a tradição real, ou seja, a entrega da coisa, foi sendo gradativamente substituída pela tradição ficta, assumindo a forma de constituto possessório, que nenhuma publicidade dava à tradição. Dessa forma, para

${ }^{64}$ Philippino. Rio de Janeiro: Typographia do Instituto Philomathico, 1870. p. 783/vol.4.

${ }^{65}$ Ibidem.,p. 780. Como não há previsão na ABNT, optou-se por transcrever os dispositivos legais com menor letra e maior margem, a fim de que se destaquem do restante do texto.

${ }^{66}$ Sá Pereira, Virgílio de. Direito das Cousas. Art. 524-678. In:Lacerda, Paulo de. (Org.). Manual do Código Civil Brasileiro. Rio de Janeiro: Jacintho Ribeiro dos Santos, 1924. p. 94/vol. VIII.

${ }^{67}$ Sá Pereira, Virgílio de. Direito das Cousas. Art. 524-678. In:Lacerda, Paulo de. (Org.). Manual do Código Civil Brasileiro. Rio de Janeiro: Jacintho Ribeiro dos Santos, 1924. p. 94 e 95/vol. VIII. 
os bens imóveis, foi utilizada a clausula constituti que substituía a tradição. Pela cláusula, operava-se a transferência da posse do bem sem a efetiva tradição, ou seja, o vendedor declarava possuir a coisa não em seu próprio nome, como senhor, mas em nome do adquirente, como detentor. Assim, a tradição de bens imóveis ficava reduzida a clausula constituti que quase sempre era inserida nas escrituras públicas pelo tabelião. ${ }^{68}$

Como com a clausula constituti nada se revelava exteriormente a terceiros, desaparecendo o elemento que até então tinha sido responsável pela publicidade das transações, ou seja, a tradição, facilitou-se a ocorrência de fraudes e a ocultação de ônus reais.

$\mathrm{Na}$ realidade, a tradição como sinal de transferência da propriedade de bens imóveis, ou como meio de publicidade, já há muito tempo não era mais um mecanismo eficiente, e isso se devia principalmente ao fato da posse e da propriedade serem institutos separados, ou seja, quem tivesse a posse não necessariamente teria a propriedade. ${ }^{69}$ Assim, não só a tradição ficta, mas também a tradição real, não mais atendiam às necessidades do momento, que exigia um ato externo que proporcionasse certa notoriedade e publicidade às modificações reais, ou seja, às transmissões de imóveis e instituições de ônus.

Para Francisco de Paula Lacerda Almeida, as fraudes já eram comuns quando a transmissão de imóveis ocorria pela tradição, tendo se tornado mais freqüentes com a adoção da clausula constituti, já que a coisa, ao permanecer sob a posse do alienante continuava parecendo lhe pertencer, o que facilitava a venda de um mesmo imóvel a compradores distintos, gerando prejuízos. ${ }^{70}$

Mesmo com tantas deficiências, foram as Ordenações Filipinas que ao longo de quase todo século XIX regularam a transmissão da propriedade imóvel.

\footnotetext{
${ }^{68}$ Para Borges mesmo após a previsão no Código Civil de 1916 de que a transmissão da propriedade imóvel ocorria com a transcrição do título no registro, a inscrição da clausula constituti nas escrituras públicas continuava necessária. Nas palavras do autor, "A cláusula, muitas vêzes, principalmente em questões possessórias, produz efeitos jurídicos apreciáveis e decisivos, de modo que é de tôda prudência que ainda seja inserta nas escrituras e contratos em que há transferência de posse". O Registro Torrens no Direito Brasileiro. São Paulo: Edição Saraiva, 1960. p.14.

${ }^{69}$ Teixeira de Freitas, Augusto. Consolidação das Leis Civis. Rio de Janeiro: Typographia Universal de Laemmert, 1865. p.CLVI.

${ }^{70}$ Direito das Cousas. Rio de Janeiro: Jacintho Ribeiro dos Santos, 1908. p. 165.
} 
Até 1822, a população podia adquirir, conforme a legislação vigente, a propriedade imóvel por meio de sesmarias doadas pela Coroa. Segundo Faoro, no início do século XIX, o sistema de sesmarias na prática já havia chegado ao fim. A terra não mais era cedida pelo Estado, era adquirida pela herança, pela doação, pela compra e venda e, sobretudo, pela ocupação, sucessão e alienação da posse. ${ }^{71}$

Cirne Lima confirmava essa assertiva ao afirmar que a Resolução de 17 de julho de 1822 apenas sancionou fato já consumado, ou seja, o regime de sesmaria não mais pertencia à estrutura territorial brasileira. O mesmo autor ressaltava, que se apoderar de terras devolutas e cultivá-las tornou-se tão comum entre os colonizadores que, com o tempo, transformou-se em modo legítimo de adquirir a propriedade. No início era um modo de aquisição paralelo às sesmarias, mais tarde, o que as substituiu. ${ }^{72}$ Assim, a ocupação foi substituindo a concessão de terras feita pelo Poder Público.

$\mathrm{Na}$ época em que a sesmaria não só era prevista na lei, mas também aplicada na prática, para se obter um pedaço de terra era necessário encaixar-se em um desses dois casos: primeiro, ter bom relacionamento com os representantes de Portugal na Colônia, já que muitas vezes ela era concedida em agradecimento a algum serviço prestado ao rei; segundo, não tendo agradecimentos a receber, a pessoa deveria provar que era um homem de posses, ou seja, que tinha recursos suficientes para investir em um latifúndio exportador de cana-deaçúcar e em seu próprio engenho. Esta exigência surgiu a partir da instalação do GovernoGeral, quando a concessão de sesmaria deixou de ter como finalidade exclusiva a ocupação e defesa do território para visar o aumento das exportações. ${ }^{73}$ A partir de então, a propriedade sesmarial passou a ser condicionada, exigindo-se o cultivo para a manutenção da posse e obtenção do domínio. ${ }^{74}$

Apesar da exigência legal de aproveitamento do solo para a permanência do domínio e da previsão de áreas máximas para doação, a ausência de fiscalização

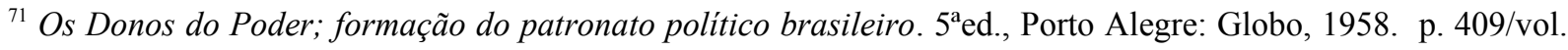
2.

${ }^{72}$ Pequena História Territorial do Brasil: Sesmarias e Terras Devolutas. $2^{\mathrm{a}}$ ed., Porto Alegre: Sulina, 1954. p. 43 e 47.

${ }^{73}$ Ibidem., p. 36.

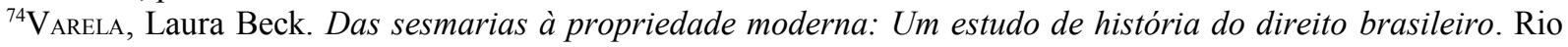
de Janeiro: Renovar, 2005. p.121. 
governamental permitiu que a lei não fosse aplicada como prevista. Dessa forma, houve a concentração territorial ligada a um grupo restrito, que apesar de possuir a terra não a explorava.

A tendência para o latifúndio parecia estar arraigada na cultura dos colonizadores. Até mesmo a ocupação, que inicialmente diferenciava-se das sesmarias por envolver apenas pequenas propriedades para o cultivo agrícola do colono livre e seus familiares, mudou de aspecto. Os posseiros, contrariando o costume que autorizava a ocupação desde que houvesse o efetivo cultivo ${ }^{75}$, conforme provisão de 14 de março de 1822, passaram a acumular cada vez mais terra, deixando parte dela improdutiva.

Com o intuito de conter essa situação, uma Resolução de Consulta da Mesa de Desembargo do Paço, de 17 de julho de 1822, assinada por José Bonifácio, suspendeu a concessão de sesmarias até a convocação da Assembléia Constituinte ${ }^{76}$. No ano seguinte, essa decisão foi ratificada numa provisão do Desembargo. Apesar de se prever que a questão da terra seria objeto de discussão na Assembléia Constituinte, não foi o que aconteceu. ${ }^{77}$

A Carta Constitucional de 1824 não fez qualquer referência às sesmarias, apenas previu em seu art. 179, dirigido às garantias fundamentais do cidadão, a proteção do direito de propriedade. Com isso, aboliu o confísco e consagrou o respeito à propriedade, assegurando prévia indenização quando o bem fosse desapropriado por utilidade ou necessidade pública. Segundo o entendimento de Pimenta Bueno, o fruto do trabalho do homem pertencia unicamente ao homem, por isso a propriedade devia ser-lhe garantida em toda sua plenitude, independente se constituía bem móvel, imóvel, corpóreo, incorpóreo. ${ }^{78}$ No entanto, o autor

\footnotetext{
75 A provisão de 14 de março de 1822 estimulava a ocupação na medida em que determinava que posses de terrenos cultivados prevaleciam sobre sesmarias posteriormente concedidas "Hei por bem ordenar-vos procedais nas respectivas medições e demarcações sem prejudicar quasqner possuidores, que tenhão effectivas culturas no terreno, porquanto devem elles ser conservados nas suas posses, bastando para titulo as reaes ordens, porque as mesmas posses prevaleção ás sesmarias posteriormente concedidas." Araripe, Tristão de Alencar. Código Civil brazileiro ou Leis Civis do Brazil. Rio de Janeiro: Laemmert \& C., 1885. p. 439.

${ }^{76}$ Resolução de 17 de julho de 1822 “- Houve S.M.I. por bem resolver a consulta que subio á sua augusta presença com data de 8 de julho do anno próximo passado pela maneira seguinte: Fique o suplicante na posse das terras que tem cultivado, e suspendão-se todas as sesmarias até a convocação da assembléa constituinte" Ibidem., p. 440.

77 Carvalho, José Murilo de. A construção da ordem: a elite política imperial. Teatro de Sombras: a política imperial. $3^{\mathrm{a}}$ ed., Rio de Janeiro: Civilização Brasileira, 2003. p. 332.

${ }^{78} \mathrm{O}$ autor completava dizendo que sem a garantia do direito de propriedade não há ampliação dos esforços ou fadigas, não há incremento ou expansão da riqueza e bem-estar social. Em seguida, questionava se algum agricultor se esforçaria em plantar o trigo se não tivesse a garantia de que a propriedade sobre a produção seria
} 
entendia que como o homem vivia em sociedade, deveria ter deveres para com esta, para com a defesa do Estado ou outras relações do bem comum. Assim, se o bem público legalmente verificado exigisse o uso ou o emprego da propriedade do cidadão, a sociedade deveria ter o direito de realizar a desapropriação, desde que existisse uma lei prevendo os casos em que caberia tal medida, regras que regulassem a indenização e que estabelecessem que antes desta ser previamente realizada, não haveria desapropriação. ${ }^{79}$

Como a Carta Constitucional não previu a questão da terra e nenhuma lei veio completar esta lacuna, o Brasil passou por um período de total anomia quanto aos bens imóveis. Além das Ordenações Filipinas que dispunham sobre a transmissão da propriedade, nenhuma outra legislação tratava da matéria. O período foi designado pelos autores como extralegal ou de posses, e correspondeu aos anos de 1822 a 1850, quando foi promulgada a Lei de Terras. Durante este período, foram poucas as tentativas do governo de solucionar a questão. As ocupações de bens imóveis já tão comuns na época das sesmarias ${ }^{80}$, tornaram-se ainda mais corriqueiras. Segundo Ricardo Pereira Lira, nesse período a situação da terra no Brasil enquadrava-se em um desses casos: sesmarias concedidas e regularizadas; sesmarias em que os concessionários só tinham a posse e não o domínio pela falta de uma das exigências legais; terras ocupadas sem título; terras que nunca tinham sido concedidas e terras devolutas, ou seja, as dadas em sesmaria que tinham caído em comisso revertendo ao patrimônio imperial. $^{81}$

Essa caótica situação da propriedade imóvel, aliada ao problema da mão-de-obra, fez a elite brasileira reavaliar a necessidade de uma política de terras. Como resposta aos anseios desse grupo, ao tentar regularizar a propriedade rural e fornecer trabalho de acordo com as necessidades e condições da época, surgiu a Lei de Terras de 1850. O projeto foi discutido pelo Conselho de Estado, em 1842, e enviado a Câmara dos Deputados no ano

sua. Direito Público Brasileiro e análise da Constituição do Império. Rio de Janeiro: José Bushatsky Editor, 1958. p. 419 e 420.

${ }^{79}$ Ibidem., p. 420.

${ }^{80}$ Conforme escreve RuY CiRne Lima, "Apoderar-se de terras devolutas e cultivá-las tornou-se cousa corrente entre os nossos colonizadores, e tais proporções essa prática atingiu que pôde, com o correr dos anos, vir a ser considerada como modo legítimo de aquisição de domínio, paralelamente a princípio, e, após, em substituição ao nosso tão desvirtuado regime de sesmarias". Pequena História Territorial do Brasil: Sesmarias e Terras Devolutas. $2^{\mathrm{a} e d}$., Porto Alegre: Sulina, 1954. p. 47.

${ }^{81}$ Campo e cidade no ordenamento jurídico brasileiro. Rio de Janeiro: Riex, 1991. p. 24. 
seguinte. Toda essa tramitação, que teve fim apenas em 1850, será objeto de estudo no próximo item. No momento, a análise centrar-se-á na Lei Orçamentária n. 317 de 1843 que colocou em destaque outra preocupação daquele tempo.

Como já foi dito, por muitos anos, no Brasil, o tráfico e a compra de escravos eram as alternativas mais usuais para aplicação de capital. Com as constantes ameaças inglesas à escravidão negra, as pessoas passaram a procurar outra maneira de investimento. Uns gastaram seu dinheiro adquirindo grandes volumes de mercadorias importadas, outros passaram a investir em negócios próprios e em títulos, buscando ampliar ainda mais sua fortuna.

Esses novos investidores apoiaram-se no Banco do Brasil, na época, de propriedade de Irineu Evangelista de Souza. Irineu, por meio da casa bancária, pegava dinheiro daqueles que sem ter mais a opção tradicional desejavam guardar seu capital com segurança e receber pequenos rendimentos por meio de juros, e emprestava a produtores necessitados a baixo custo.

Essa nova situação estimulou a economia. O capital até então retido, destinado unicamente ao tráfico negreiro, passou a buscar novas alternativas, sendo utilizado não só na agricultura, mas também no comércio, serviços e até em uma incipiente indústria (a maioria de propriedade do próprio Irineu Evangelista). Com a economia estimulada, um futuro crescimento econômico parecia próximo, mas para isso era necessário organizar uma legislação coerente com esse momento histórico.

O sistema capitalista exige uma propriedade apta a ser objeto de empréstimos. Aquele que deseja obter capital para qualquer ordem de investimento precisa garantir o seu pagamento e, para isso, o instituto jurídico da hipoteca torna-se indispensável. Um empréstimo seguro possibilita maior quantidade de dinheiro, garantido a juros menores.

O deputado J. M. Pereira da Silva, na sessão de 18 de março de 1843 defendeu perante a Comissão de Justiça Civil o entendimento de que era absolutamente necessária a adoção de uma lei que fixasse regras invariáveis e um sistema claro de hipotecas, com o objetivo de assegurar a propriedade individual e acabar com os abusos que uma legislação 
civil imperfeita permitia. ${ }^{82} \mathrm{O}$ mesmo deputado apresentou um projeto sobre a matéria em $1^{\circ}$ de abril de $1843^{83}$. Diante da iniciativa, a Comissão de Justiça Civil, em sessão do dia 19 de abril, entendeu estar exonerada de organizar um projeto sobre hipotecas, já que o deputado tinha oferecido um, limitando-se unicamente a apresentar um parecer após a discussão da matéria ${ }^{84}$. O projeto de J. M. Pereira da Silva acabou esquecido, não sendo nem mesmo utilizado como base para a elaboração de leis posteriores sobre o instituto.

Foi nesse momento que surgiu a Lei Orçamentária n. 317, de 21 de outubro de 1843, que apesar de ter como objetivo principal fixar receita e orçar despesa para o exercício de 1843-1844 e 1844-1845, estabeleceu em seu artigo 35 o Registro Hipotecário com o fim restrito de inscrever hipotecas. Ressalta-se que esse dispositivo era o único da lei que fazia referência ao registro hipotecário, não sendo resultado do projeto de Pereira da Silva, mas sim uma acanhada demonstração da (des) preocupação dos legisladores com a matéria. A Lei Orçamentária de 1843 previa:

Art. 35 - "Fica creado hum Registro geral de hipotecas, nos lugares e pelo modo que o Gôverno estabelecer nos seus Regulamentos"

Esse artigo foi regulamentado em 14 de novembro de 1846 pelo decreto n. 482 , sem, contudo, fazer menção à transcrição das transmissões da propriedade imobiliária em nenhum de seus 33 artigos. O novo decreto referia-se unicamente à hipoteca, dispondo acerca do local em que ela deveria se registrada (art. $2^{\circ}$ e $3^{\circ}$ ), a pessoa responsável em requerer o registro (art. $5^{\circ}$ ) e em executá-lo (art. $1^{\circ}$ ), os documentos necessários (art. $6^{\circ}$ ), o procedimento (art. $10^{\circ}$ a 12), os efeitos do registro (art. 13 a 15), os casos de averbação (art. 18 a 20), os livros (art. 22 e 23), a responsabilidade dos Tabeliães de registro (art. 29), os emolumentos cobrados (art. 32), entre outros.

Assim, uma lei prescrevendo sobre a hipoteca surgiu antes de qualquer política que visasse a corrigir a situação fundiária caótica por que passava o Brasil recém

\footnotetext{
${ }^{82}$ Brasil. Annaes do Parlamento Brazileiro. Camara dos Srs. Deputados. Primeira Sessão de 1843. Tomo Segundo. Rio de Janeiro: Typographia da Viúva Pinto \& Filho, 1882. p. 324.

${ }^{83}$ Brasil. Annaes do Parlamento Brazileiro. Camara dos Srs. Deputados. Primeira Sessão de 1843. Tomo Segundo. Rio de Janeiro: Typographia da Viúva Pinto \& Filho, 1882. p. 595 e 596.

${ }^{84}$ Brasil. Annaes do Parlamento Brazileiro. Camara dos Srs. Deputados. Primeira Sessão de 1843. Tomo Segundo. Rio de Janeiro: Typographia da Viúva Pinto \& Filho, 1882. p.792.
} 
independente. Apesar das Ordenações Filipinas tratarem da transmissão de bens imóveis, que ocorria pela tradição, não havia qualquer previsão de delimitação ou registro de terras. $\mathrm{Na}$ verdade, o Alvará de 5 de outubro de 1795 havia exigido que se medissem e demarcassem as sesmarias, no entanto, muito pouco foi feito nesse sentido. A ineficácia da determinação foi tamanha, que um ano depois, o Alvará de 10 de dezembro suspendia a exigência, oferecendo como justificativa o número ínfimo de "geometras", motivo esse, aliás, que foi utilizado outras vezes. $^{85}$

Quanto ao registro, Duarte Coelho Pereira (primeiro donatário da capitania hereditária de Pernambuco por carta de doação de 10 de março de 1534), instituiu um registro da carta de sesmaria no livro das datas em Pernambuco com caráter meramente administrativo, objetivando ter maior controle sobre as distribuições. No entanto, com o Regimento dos Provedores em 1549, o registro passou a ser obrigatório, sujeitando a sua não realização em prazo determinado, à perda da concessão. O registro deveria ser feito na Provedoria e tinha como função informar a autoridade sobre áreas ainda desocupadas. ${ }^{86}$ Acontece que, mais uma vez a exigência não foi cumprida por muitos $\operatorname{sesmeiros}^{87}$ e a Coroa, em poucos casos, penalizou os irregulares. Dessa feita, perdeu-se a oportunidade de obter-se um quadro, ainda que incipiente, da situação das terras na Colônia.

Como é difícil pensar em um registro de hipotecas sem que haja um registro das transmissões da propriedade imóvel, o dispositivo da Lei Orçamentária e seu regulamento não tiveram grande repercussão jurídica e econômica. ${ }^{88}$ A razão do surgimento de uma legislação tão insuficiente é explicada por CALDEIRA, para quem havia total desinteresse de grande parte da sociedade em regular o sistema de crédito, uma vez que a organização mercantilista do tráfico negreiro "privilegiava o poder pessoal dos donos do dinheiro". Dessa maneira, em 1848, ainda não havia no país títulos com garantias legais, a ausência de normas jurídicas

\footnotetext{
${ }^{85}$ Costa Porto, José da. O sistema sesmarial no Brasil. Brasília: Universidade de Brasília, [1979?]. p. 110 e 113.

${ }^{86}$ Costa Porto, José da. O sistema sesmarial no Brasil. Brasília: Universidade de Brasília, [1979?]. p. 97-99.

${ }^{87}$ Conforme Costa Porto, "Depois de janeiro de 1699, havia casos em que o colono, recebendo a carta, não a registrava por astúcia, tentando fugir ao pagamento do foro, segundo se adverte em parecer de 1739: alguns colonos não haviam efetuado o pagamento do foro - <<que parece que por esse efeito de o não pagarem tiveram caução de não reistrarem a carta de sesmarias no livro de datas $>>$ ". Ibidem., p. 98.

${ }^{88}$ Borges, João Afonso. O Registro Torrens no Direito Brasileiro. São Paulo: Saraiva, 1960. p.16.
} 
sobre a matéria fazia com que a cobrança de dívidas perante a justiça se tornasse praticamente impossível e a decisão sobre falências e concordatas se arrastassem por anos. O malefício trazido por essa situação era enorme, já que assegurar o crédito apenas por meio da garantia pessoal diminuía a quantidade de capital emprestado e impedia o desenvolvimento de um sistema financeiro. ${ }^{89}$

Se de um lado, grande parte da sociedade não se preocupava com o sistema de crédito, de outro, havia uma pequena parcela que lutava pela sua regulamentação. Nesse contexto, destacam-se Irineu Evangelista e todos aqueles que, com sua influência, conseguiram que a discussão sobre a matéria fosse pelo menos iniciada entre os legisladores. Daí a inclusão do artigo 35 na Lei Orçamentária e o Regulamento de 1846.

Como grande parte da sociedade estava desinteressada por mudanças, é provável que as insuficiências da Lei Hipotecária não tenham preocupado, naquele momento, esses mesmos legisladores. Todavia, mais tarde, com a ampliação das relações comerciais e o aumento do valor da propriedade imóvel, eles perceberam que era preciso a promulgação de uma nova lei. E para que a lei garantisse um bom Registro de Hipotecas, era indispensável a previsão de um sistema registral.

\subsection{LeI N. 601 de 1850: Registro do VigÁRIo}

Foi apenas em 1842 que a questão da terra (e não só da hipoteca) retornou à pauta, quando o ministro do Império Cândido José de Araújo Viana, por avisos de 6 de junho e 8 de julho, requereu à Seção dos Negócios do Império do Conselho de Estado que elaborasse projetos legislativos sobre sesmarias e colonização estrangeira, ou seja, imigração. ${ }^{90}$

$\mathrm{Na}$ realidade, segundo CALDEIRA, como o gabinete conservador vinha, às escondidas, preparando o país para o fim do tráfico negreiro, ele já tinha designado alguns amigos para elaborar um projeto de lei sobre terras, que assegurasse aos grandes fazendeiros

\footnotetext{
${ }^{89}$ Mauá: empresário do Império. São Paulo: Companhia das Letras, 1995. p. 198.

${ }^{90}$ Carvalho, José Murilo de. A construção da ordem: a elite política imperial. Teatro de Sombras: a política imperial. $3^{\text {a }}$ ed., Rio de Janeiro: Civilização Brasileira, 2003. p. 332.
} 
extensas glebas. Pela nova lei, a posse não seria mais modo de aquisição de propriedade, o que limitava o número de pessoas pleiteando certas terras. Afinal, somente aqueles que tivessem recurso para contratar advogado e/ou influência para nomear juízes que reconhecessem a veracidade de escrituras de aquisição, procurariam o Judiciário. Desse modo, haveria a possibilidade dos grandes fazendeiros de café expandirem ainda mais suas terras, principalmente sobre áreas pertencentes a posseiros analfabetos ou pouco influentes. $\mathrm{O}$ aumento das dimensões da propriedade dos cafeicultores compensaria, por sua vez, uma eventual privação de mão de obra. ${ }^{91}$

Outra medida para abrandar as perdas dos fazendeiros com o fim do tráfico consistia na elaboração de um projeto, que estimulasse a vinda de imigrantes por meio de subsídios governamentais. Por fim, o pacote de providências seria complementado com a elaboração de um Código Comercial, que permitisse o desenvolvimento do sistema financeiro. 92

Dessa maneira, o que até então vinha sendo feito às escuras pelo gabinete conservador, na casa de particulares, passou a ser de conhecimento de todos quando o Ministro do Império requereu à Seção dos Negócios do Império do Conselho de Estado que aprontasse a lei.

A Seção apresentou o projeto com 10 artigos, em 8 de agosto do mesmo ano (1842). Tratava-se de uma única proposta, que abrangia os dois assuntos. Contudo, afirmava claramente, que seu principal objetivo era promover a imigração de trabalhadores "pobres, moços e robustos". Os autores da lei receavam que as diversas leis contrárias ao tráfico negreiro diminuíssem a oferta de mão-de-obra na lavoura, prejudicando a agricultura. Ainda, a facilidade em obter-se terra dificultava o aumento do trabalho livre. A idéia da Seção era proibir a doação e ocupação de terras, só possibilitando a sua aquisição por meio de compra. Dessa maneira, aquele que obtivesse terra, por força, teria dinheiro, seja por vir de família abastada, ou por guardar suas economias depois de muitos anos de roçado como trabalhador livre. ${ }^{93}$

\footnotetext{
${ }^{91}$ Mauá: empresário do Império. São Paulo: Companhia das Letras, 1995. p. 199.

${ }^{92}$ CAldeIRA, Jorge. Mauá: empresário do Império. São Paulo: Companhia das Letras, 1995. p. 199 e 200.

${ }^{93}$ Carvalho, José Murilo de. A construção da ordem: a elite política imperial. Teatro de Sombras: a política imperial. $3^{\text {a }}$ ed., Rio de Janeiro: Civilização Brasileira, 2003. p. 332.
} 
O projeto de lei era inspirado nas idéias de Edward GibBon Wakefield, principalmente naquelas expostas em um folheto intitulado A Letter from Sidney de 1829, na suposição de que em regiões com terra abundante era difícil compelir alguém a trabalhar na fazenda de outrem, a não ser que fosse por meio da escravidão.

WAKEFIELD tinha elaborado um sistema para ser adotado na Austrália onde a terra era abundante e a mão de obra escassa. Nele, a terra era encarecida artificialmente para que os colonos tivessem dificuldade em consegui-la rapidamente. Assim, o colono deveria trabalhar primeiro para depois obter meios de adquirir sua propriedade. Com o dinheiro obtido na venda dos imóveis, o Governo poderia custear o transporte de trabalhadores da metrópole para a colônia, o que permitia ao sistema auto-alimentar-se. ${ }^{94}$ WAKEFIELD também previa que as terras deveriam ter um preço fixo e uniforme, que só variaria com a extensão e não com a qualidade do terreno, proibindo a venda de terras devolutas em hasta pública. ${ }^{95}$ Por fim, dispunha sobre a criação de um imposto sobre a renda.

Baseado nas idéias de WAKEFIELD, o projeto de lei também previu a medição e titulação das sesmarias. Caso o proprietário não cumprisse a exigência no prazo de 6 anos, poderia perder a terra para a nação. O projeto ainda limitava o tamanho das posses, o que trouxe grandes discórdias. ${ }^{96}$

A proposta da Seção foi pouco modificada no Conselho Pleno, havendo apenas uma inclusão sugerida por BERNARDO DE VASCONCELOS que consistia na cobrança de um imposto sobre a terra e não sobre a renda. O imposto territorial era baseado no tamanho da propriedade, e seu intuito era estimular o uso produtivo do solo e fornecer rendimentos para subsidiar a imigração. Caso o tributo não fosse pago por três anos consecutivos ou interrompidos, a propriedade retornava à Coroa. ${ }^{97}$

Muitos dispositivos do projeto foram criticados pelos deputados (como a estipulação de um imposto territorial e a proposta de limitar o tamanho das propriedades),

\footnotetext{
${ }^{94}$ Ibidem., p. 333.

${ }^{95}$ Lima, Ruy Cirne. Pequena História Territorial do Brasil: Sesmarias e Terras Devolutas. $2^{\mathrm{a}}$ ed., Porto Alegre: Sulina, 1954. p. 81.

${ }^{96}$ Carvalho, José Murilo de. A construção da ordem: a elite política imperial. Teatro de Sombras: a política imperial. $3^{\mathrm{a}}$ ed., Rio de Janeiro: Civilização Brasileira, 2003. p. 335.

${ }^{97}$ Ibidem., p. 333.
} 
destacando-se a oposição à exigência de se medir as terras. A justificativa era de que não havia especialistas suficientes para medir e demarcar a propriedade e que a execução de tal providência seria muito onerosa, reduzindo a lucratividade da propriedade rural. Mesmo com todas as críticas, esse aspecto foi mantido no texto legal. ${ }^{98}$

A crença de que o excesso de inovações do projeto faria com que ele não fosse aplicado na prática, facilitou sua aprovação e afastou a imprensa que não participou de sua divulgação. ${ }^{99}$

Enviado ao Senado em 2 de outubro de 1843, o projeto voltou à Câmara em 1850, onde foi votado rapidamente. Durante o período liberal de 1844 a 1848, sua tramitação sofreu uma série de interrupções, apenas retornando efetivamente à pauta de discussões com a volta dos conservadores ao poder. Mais uma vez, discutiu-se a questão dos posseiros e sesmeiros; no entanto, nenhuma modificação foi aceita. Outra questão que causou muito debate foi o fato do sistema de Wakefield ter fracassado na Austrália, e o sistema implementado nos Estados Unidos de venda de pequenos lotes de terra ter prosperado. ${ }^{100}$

De uma forma geral, houve maior incentivo à vinda de colonos, procurando-se retirar do projeto qualquer medida que pudesse afastá-los, como aquelas que buscavam evitar que eles se afastassem do trabalho assalariado, como, por exemplo, a proibição de comercializar. Também foram excluídos do projeto, o imposto territorial e a previsão de perda

\footnotetext{
98 Após analisar os debates legislativos, Vıотті conclui "Se olharmos mais de perto o projeto de lei e os argumentos daqueles que o defenderam na Câmara dos Deputados, torna-se óbvio que os legisladores queriam fomentar o desenvolvimento do sistema de plantation, que constituía a base da economia brasileira. Eles estavam dispostos a dar ao governo o poder para controlar a terra e o trabalho, apenas para assegurar o sucesso da economia do tipo plantation. Em relação à terra, o governo não era visto como um proprietário, mas como um representante do povo, de quem derivava seu poder para controlar a terra e o trabalho. De acordo com as modernas idéias de lucro e produtividade, os legisladores procuraram forçar o proprietário rural a usar a terra de uma maneira mais racional. Conscientes da necessidade de um novo tipo de trabalho para substituir o escravo, eles recorreram à imigração como fonte de trabalho. Finalmente, supondo que num país onde a terra era disponível em grandes quantidades, o imigrante poderia se tornar proprietário rural, em vez de trabalhar em uma fazenda, eles tentaram tornar mais difícil o acesso à terra, a fim de forçar os imigrantes a trabalharem nas fazendas." Da Monarquia à República: momentos decisivos. $8^{\text {a }}$ ed., São Paulo: Fundação Editora UNESP, 2007. p. 182 e 183.

${ }_{99}$ Carvalho, José Murilo de. A construção da ordem: a elite política imperial. Teatro de Sombras: a política imperial. $3^{\mathrm{a}}$ ed., Rio de Janeiro: Civilização Brasileira, 2003. p.340.

${ }^{100}$ Ibidem., mesma página.
} 
da propriedade para aquele que não a registrasse no prazo (nesse caso substituída pela pena de multa). ${ }^{101}$

Após as modificações, o projeto retornou à Câmara que, discutindo englobadamente todas as emendas do Senado, aprovou-o após quatro sessões de debates ${ }^{102}$, dando origem a lei n. 601 de 18 de setembro de 1850, conhecida como Lei de Terras, que pouco diferia da versão enviada pelo Senado.

Apesar de pequenas inovações, a Lei de Terras tinha em substância as características do sistema de WAKEFIELD (o fracasso do sistema na Austrália não preocupou os legisladores brasileiros) como é possível comprovar com seus artigos $14, \S 2^{\circ}, 18$ e 19 . O art. 14 autorizava a venda de terras devolutas e seu $\S 2^{\circ}$ fixava o preço ${ }^{103}$. O art. 18 permitia que o governo importasse colonos livres. Por fim, o art. 19 estabelecia que o valor obtido com a venda das terras seria utilizado unicamente para medir as terras devolutas e importar colonos.

Segundo Murilo de Carvalho, a demora na aprovação da proposta legislativa e as alterações feitas no Senado refletiam a situação político-econômica pela qual passava o país. Por um lado, o domínio liberal composto principalmente por políticos de São Paulo e Minas Gerais, não tinha interesse em aprovar o projeto. De outro, a política inglesa de cessação do tráfico de escravos não havia surtido efeitos, aumentando o número de escravos introduzidos no país. Assim, o receio dos fluminenses de ficarem sem mão de obra foi por certo tempo afastado, diminuindo a pressão por uma rápida aprovação da lei. Além disso, o êxito do sistema de terras implantado nos Estados Unidos fez voltar a discussão sobre a melhor forma de atrair espontaneamente imigrantes. ${ }^{104}$

Logo após a publicação da Lei de Terras, o Conselho de Estado foi convocado para elaborar seu regulamento. Surgiu então o decreto n. 1.318 de 30 de janeiro de 1854. Em seus 108 artigos disciplinou, entre outras matérias, a Repartição de Terras Públicas (criada

\footnotetext{
${ }^{101}$ Ibidem., mesma página.

102 Brasil. Annaes do Parlamento Brazileiro. Câmara dos Srs. Deputados. Sessão de 1850. Tomo Quarto. Rio de Janeiro: Typographia de H. J. Pinto, 1880. Sessão de 30 de agosto (p. 731 a 746), sessão de 31 de agosto (p. 753 a 762), sessão de 2 de setembro (p. 765 a 784) e sessão de 3 de setembro (p. 785 a 791).

${ }^{103}$ Apesar da lei tratar sobre aquisição de terras devolutas, esse tema não será objeto de estudo.

${ }^{104}$ A construção da ordem: a elite política imperial. Teatro de Sombras: a política imperial. $3^{\mathrm{a}}$ ed., Rio de Janeiro: Civilização Brasileira, 2003. p.341.
} 
neste mesmo ano) que visava dirigir a medição, revalidação, legitimação e discriminação das terras públicas e de particulares a qualquer título legítimo. Com efeito, as normas instituídas pelo decreto objetivavam definir o que era do domínio público e regular a situação das sesmarias, posses e ocupações por meio da aferição do que estava no domínio e na posse de particulares. O regulamento ainda buscava realizar o parcelamento de terras devolutas em pequenas e médias propriedades rurais para posterior venda em hasta pública e à vista.

Ademais, passou a ser tarefa de Juízes e delegados informar sobre a existência de terras devolutas nas províncias em que trabalhavam (art. 87) e os párocos ficaram encarregados de receber as declarações para registro das terras, no que ficou denominado de "Registro do Vigário" (art. 97).

Dessa forma, com o regulamento, o Estado mudou sua postura no que era relativo as terras devolutas. Até o surgimento desse decreto, com a existência apenas da Lei de Terras, cabia ao particular fazer a demarcação de sua propriedade e o remanescente era considerado público. Agora, era o Estado que tomava a iniciativa, demarcando suas terras. Pelo decreto n. 1.318 de 1854, cabia ao Inspetor Geral de Medições realizar o processo de medição das terras devolutas. Já o processo de medição e demarcação das terras particulares ocorria perante o Juiz Comissário e resultava na obtenção de um título expedido pela repartição pública competente. Segundo VAREla, o instrumento que formalizava o direito de propriedade nesse momento ainda não era um título transcrito na Serventia Imobiliária, mas sim um ato resultante de um contencioso sui generis. ${ }^{105}$

Confirma a assertiva, no referente à medição das terras particulares, o art. 13 da Lei de Terras que já previa:

“Art. 13. O mesmo Governo fará organizar por Freguesia o registro das terras possuídas, sobre as declarações feitas pelos respectivos possuidores, impondo multas e penas áquelles que deixarem de fazer nos prazos marcados as ditas declarações, ou as fizerem inexatas"

No entanto, foi apenas o decreto de 1854, que trouxe o procedimento que deveria ser realizado para se obter a medição das terras. A exigência era feita nos seguintes termos:

${ }^{105}$ Das sesmarias à propriedade moderna: Um estudo de história do direito brasileiro. Rio de Janeiro: Renovar, 2005. p. 149. 
"Art. 91. Todos os possuidores de terras, qualquer que seja o título de sua propriedade, ou possessão são obrigados a fazer registrar as terras, que possuírem, dentro dos prazos marcados pelo presente Regulamento, os quaes se começarão a contar, na Côrte, e Província do Rio de Janeiro, da data fixada pelo Ministro e Secretário d'Estado dos Negócios do Império, e nas Províncias, da fixada pelo respectivo Presidente."

Pelas disposições do Capítulo IX do decreto de 1854, cabia ao possuidor escrever ou fazer escrever em seu nome a declaração de registro em dois exemplares iguais (art.93). Aquele que não fizesse essa declaração por escrito, no prazo estabelecido, seria multado pelo encarregado do registro na respectiva Freguesia (art. 95). A multa era cobrada como dívida da Fazenda Nacional (art. 96).

Os Vigários de cada Freguesia do Império eram responsáveis por receber as declarações, sendo incumbidos de proceder ao registro dentro de sua Freguesia (art. 97). Determinado o início da contagem do prazo, conforme o art. 91, os Vigários informavam aos fregueses da obrigação de registrarem suas terras no prazo de 2 anos (art. 92 e 98). As instruções deveriam ser dadas nas Missas e publicadas por todos os meios, a fim de que todos os fregueses tivessem conhecimento delas (art. 99).

As declarações das terras possuídas deveriam conter o nome do possuidor, a designação da Freguesia em que a propriedade estava situada, sua extensão e limites (art. 100). Como já foi dito, o possuidor deveria entregar essa declaração em dois exemplares. Essa exigência ocorria porque uma das vias era levada a registro, e a outra, depois de datada e assinada pelo pároco, era devolvida ao apresentante para lhe servir de prova do cumprimento da obrigação (art.101). Antes de receber a declaração, o vigário deveria conferir se estavam presentes as informações necessárias, ou seja, aquelas exigidas no art. 100, e se não havia erros notórios. Caso existissem erros manifestos, pedia sua correção, instruindo o apresentante do modo de fazê-lo. Se a parte insistisse na realização do registro de sua declaração da maneira como estava, sem qualquer correção, o Vigário deveria aceitá-la (art. 102).

O conteúdo da declaração deveria ser lançado pelo pároco (ou seu escrevente) textualmente em um livro de registro que deveria ser por ele aberto, numerado, rubricado e encerrado. Pela transcrição, cobravava-se emolumento cujo valor era definido de acordo com o número de letras que contivesse o exemplar, num total de dois reaes por letra. A quantia cobrada deveria constar obrigatoriamente nos dois exemplares (art. 103). 
Os exemplares que ficavam com o Vigário deveriam ser por ele emassados (cobertos por alguma espécie de capa) e numerados pela ordem de recebimento, anotando em cada um a folha em que foi registrado (art. 104).

O Pároco que extraviasse alguma declaração, não fizesse o registro ou nele cometesse algum erro, alterando ou tornando ilegíveis os requisitos do art. 100, seria obrigado a restituir os emolumentos que tivesse recebido para aquele registro, além de pagar uma multa de 50 a 200 mil réis ${ }^{106}$, sendo tudo cobrado executivamente (art. 105). Da mesma forma, aquele possuidor que fizesse declaração falsa, pagaria multa de 50 a 200 mil réis. Além disso, se a falta fosse grave, o juiz poderia também impor pena de 1 a 3 meses de prisão (art. 106).

Findo o prazo previsto para o registro das terras possuídas, os exemplares emassados seriam mantidos nos Arquivos das Paróquias e os livros com a transcrição seriam remetidos ao Delegado do Diretor Geral das Terras Públicas da Província ${ }^{107}$ respectiva, para com base neles formar-se o registro geral de terras possuídas na Província. Desse registro, enviar-se-ia uma cópia ao Diretor Geral de Terras Públicas, para que este organizasse o registro geral de terras possuídas no Império (art. 107).

Por fim, no relativo ao registro do Vigário, o decreto determinava que todas aquelas pessoas que arrancassem marcos, estacas divisórias ou destruíssem sinais, números e declarações seriam punidas com multa de 200 mil réis, além de outras penas que as leis em vigor previssem (art. 108).

Após a descrição de todo o procedimento, é possível fazer algumas considerações.

A primeira é que o Estado aproveitou-se da estrutura eclesiástica para organizar a terra. A escolha dos párocos para realizar o registro das terras possuídas, deve-se ao fato deles serem membros de um grupo organizado, presente em grande parte das vilas e povoações de todo o país. ${ }^{108}$

\footnotetext{
${ }^{106}$ O decreto 1.318 de 1854 obtido no site do Senado Federal, utiliza o termo "reaes" no artigo 103 e "réis" no 105. Disponível em: <http://www6.senado.gov.br/legislacao/ListaPublicacoes.action?id=102306>. Acesso em: 28 de abril de 2008.

${ }^{107}$ Subordinado ao Presidente da Província, o Delegado do Diretor Geral das Terras Públicas era responsável pela direção da Repartição Especial das Terras Públicas (art. $6^{\circ}$ ).

${ }^{108}$ VARELA, Laura Beck. Das sesmarias à propriedade moderna: Um estudo de história do direito brasileiro. Rio de Janeiro: Renovar, 2005. p. 149.
} 
A segunda consideração a ser feita é que o registro do Vigário não constituía prova de propriedade, não dava direito aos possuidores, tinha mera função estatística ${ }^{109}$, ou seja, servia para definir o total de terras particulares e seus possuidores. No entanto, nem esse conhecimento tornava-se exato, já que não havia a obrigatoriedade de que o registro expressasse a verdade. Com efeito, ao mesmo tempo em que o decreto trazia uma série de dispositivos que visavam evitar informações falsas dos possuidores, como a exigência de que o vigário analisasse a declaração e apontasse erros formais e materiais, e a multa ou até mesmo prisão para aquele que fizesse declaração errônea, ele determinava que o vigário não recusasse nenhuma declaração, se o apresentante se negasse a corrigi-la e insistisse em registrá-la.

Essas imperfeições do decreto foram ainda mais intensificadas com o aviso de 5 de dezembro de 1854 que dispunha:

"Deve ser registrada toda e qualquer porção de território, qualquer que seja a sua extensão, sendo esta mencionada approximadamente quando não fôr conhecida com exatidão".

Assim, o próprio Império permitia que as medidas, quando não conhecidas com exatidão pudessem ser indicadas aproximadamente, o que mais uma vez prejudicava o conhecimento fiel da situação das terras no país. O ideal era que a legislação exigisse a medição e a delimitação de todo bem imóvel. Mesmo fornecendo informações erradas, incompletas ou inexatas, CiRne Lima acreditava que o registro paroquial teve sensível importância como órgão de informação e estatística, remediando a desordem criada pelo regime de posses, que era de total iniciativa dos povoadores. ${ }^{110}$

A terceira consideração a ser feita é a de que apesar de o pároco ser responsável pelo registro e pela sua análise formal e material, não podia avaliar a legitimidade da posse. A

\footnotetext{
${ }^{109}$ Quanto à função estatística do registro do vigário, manifestou-se TeIXEIRA DE FREITAS "Com esse registro nada se predispõe, como pensão alguns, para o cadastro da propriedade immovel, base do regimen hypothecario germanico. Teremos uma simples descripção estatística, mas não uma excata conta corrente de toda a propriedade immovel no paiz, demonstrando sua legitimidade, e todos os seus encargos. O systema cadastral é impossível entre nós". Consolidação das Leis Civis. Rio de Janeiro: Typographia Universal de Laemmert, 1865. p. 431.

${ }^{110} \mathrm{O}$ mesmo autor acreditava que o mérito do legislador de 1850 estava em duas providências tomadas, quais sejam: a criação do registro do vigário, que acabou com a desordem do regime de posses e a distinção das terras públicas e particulares. Pequena História Territorial do Brasil: Sesmarias e Terras Devolutas. 2aed., Porto Alegre: Sulina, 1954. p. 66.
} 
análise material restringia-se apenas a erros notórios, conforme foi explicado meses depois da publicação do regulamento através do Aviso de 22 de dezembro de 1854:

"A declaração para o registro, apresentada por aquelle que tinha abandonado por annos a posse de um sítio adquirido por compra, deve ser aceita, porque aos vigarios não compete avaliar a legitimidade das posses".

Feitas essas considerações, resta verificar a efetividade da Lei de Terras e seu regulamento. Segundo ViOtTI da CostA, a Lei de 1850 não conseguiu atingir todos os seus objetivos. Os cafeicultores, em face da proibição do tráfico e do comércio de escravos, passaram a comprá-los de áreas decadentes do país, resolvendo provisoriamente o problema da mão-de-obra e fazendo com que os imigrantes só fossem introduzidos em grande número nas fazendas, na década de $1880 .{ }^{111}$

Segundo Murilo de Carvalho, os primeiros relatórios emitidos pelos ministros do Império (de 1855 a 1860) e da Agricultura, Comércio e Obras Públicas (1860 a 1889) comprovam as frustrações na aplicação da lei. Neles, os ministros e funcionários das repartições responsáveis por aplicar a Lei de Terras e seu regulamento, enumeravam as dificuldades enfrentadas. ${ }^{112}$

É com base nesses relatórios que se afirma que, em 1855, apenas dez províncias brasileiras haviam informado sobre a existência de terras devolutas e, mesmo assim, de forma vaga, sem precisar as dimensões. Apenas três tinham informado sobre sesmarias e posses a exigirem revalidação e legitimação, e de maneira incompleta. Havia inclusive alguns municípios que afirmavam não ter nenhuma irregularidade na terra, o que era impossível. A resistência à lei fez com que, em 1877, se reconhecesse que ela era letra morta em vários dispositivos. ${ }^{113}$

A situação do registro paroquial de terras também era caótica. Havia resistência dos próprios párocos, arbítrios nas declarações, lentidão no processo. As multas previstas para aqueles que não realizassem o registro no prazo estipulado não surtiram efeito, já que os

\footnotetext{
${ }^{111}$ Da Monarquia à República: momentos decisivos. $8^{\mathrm{a}}$ ed., São Paulo: Fundação Editora UNESP, 2007. p. 195.

${ }_{112}$ A construção da ordem: a elite política imperial. Teatro de Sombras: a política imperial. $3^{\mathrm{a}}$ ed., Rio de Janeiro: Civilização Brasileira, 2003. p. 342.

${ }^{113}$ Ibidem., mesma página.
} 
proprietários simplesmente não pagavam e o governo não tinha meios de realizar a cobrança. ${ }^{114}$

No relativo à discriminação de terras públicas, ela também não avançou já que foram poucas as províncias que comunicaram a respeito e as que assim procederam fizeramno de forma vaga. Ademais, o pouco número de agrimensores tornava a medição e demarcação onerosa e demorada. Os gastos com a delimitação dos lotes para entrega aos imigrantes foram tão altos que o relatório de 1871 pedia o fim da medição prévia e a concessão gratuita da terra. Caberia assim aos concessionários arcarem com os custos da medição. $^{115}$

Como conseqüência das dificuldades enfrentadas com a Lei de Terras, a política de imigração também não surtiu efeitos. Os Estados Unidos apresentavam-se como destino muito mais vantajoso, pois as terras oferecidas eram de qualidade, havia meios de transporte, maiores facilidades na aquisição e ausência de escravidão nas áreas de colonização. ${ }^{116}$

Outro fator que dificultou a implantação da Lei de Terras foi a instabilidade dos órgãos responsáveis pela fiscalização do processo de discriminação de terras públicas (que em menos de 15 anos foram alterados diversas vezes) $)^{117}$. Assim, o próprio Estado parecia não fazer muito esforço para aplicá-la, o que levava a não poder se esperar uma atitude muito diferente do particular.

\footnotetext{
${ }^{114}$ Segundo Murilo de Carvalho, “o ponto é bem demonstrado pelo Relatório de 1864 que dá o balanço dos primeiros dez anos de vigência da lei em treze províncias. Tinham sido registradas no período 230.440 posses e multados 7.775 posseiros no valor global de 460:265\$. Desse total de multas foram arrecadados apenas 22:300\$”. A construção da ordem: a elite política imperial. Teatro de Sombras: a política imperial. $3^{\mathrm{a}}$ ed., Rio de Janeiro: Civilização Brasileira, 2003. p.343.

${ }^{115}$ Ibidem., mesma página.

${ }^{116}$ Ibidem., mesma página.

117 Conforme Murilo de Carvalho, "As dificuldades refletiam-se na organização da burocracia encarregada de implementar a lei. A Repartição Geral de Terras Públicas, que possuía delegacias em algumas províncias, foi extinta em 1861, como conseqüência da implantação do Ministério da Agricultura, Comércio e Obras Públicas. Foi substituída pela $3^{\text {a }}$ Diretoria de Terras Públicas e Colonização do novo Ministério. Em 1863, a Diretoria contava com apenas dez funcionários na capital, $25 \mathrm{em}$ cinco delegacias provinciais (Espírito Santo, São Paulo, Santa Catarina, Paraná e Rio Grande do Sul), 14 engenheiros distribuídos por 11 províncias e 17 juízes comissários. As delegacias foram sendo paulatinamente fechadas, restando apenas a do Rio Grande do Sul em 1871. Em 1870 criou-se uma Comissão do Registro Geral e Estatísticas das Terras Públicas e Possuídas que, por sua vez, foi transformada em 1875 em Inspetoria Geral das Terras e Colonização. Houve ainda uma Agência Oficial de Colonização criada em 1863 e incorporada à Inspetoria em 1875. Mudavam as repartições mas continuavam as dificuldades e a incapacidade do governo em superá-las.” Ibidem., p. 344 e 345.
} 
Diante desse contexto, muitas terras não foram cadastradas e as que foram tinham seus registros questionados, já que muitos deles foram feitos com base em declarações errôneas. No concernente à medição e demarcação de terras devolutas, a execução foi pequena, o que permitiu que as ocupações ilegais continuassem. Além disso, a legitimação das sesmarias quase não progrediu. Dessa forma, o quadro demonstra que a lei de 1850 não alcançou os efeitos esperados.

Como razões para o seu fracasso, é possível indicar: o desinteresse dos proprietários, a falta de recursos humanos (poucos agrimensores e engenheiros), alto custo da medição, fraqueza da burocracia central em nível local (principalmente, párocos), desorganização do Estado. ${ }^{118}$

O grande problema foi que a Lei de Terras não veio resolver a situação caótica da propriedade imobiliária. Seu intuito principal, como já visto, era solucionar a questão da mãode-obra. Só que para superar a dificuldade em se obter braços para a lavoura, era necessário regularizar a terra, definindo a área que pertencia a particulares e a que era do Estado. Afinal, definindo-se as áreas devolutas, poder-se-ia pensar em atrair colonos para trabalhar provisoriamente nas fazendas, com a promessa de futura aquisição dessas mesmas terras.

É interessante notar como, por muito tempo, a terra não foi assunto central das discussões e preocupações dos políticos brasileiros, nem mesmo da elite agrária que os sustentava. Apesar da previsão legal, sesmeiros e posseiros não tinham interesse em medir e demarcar suas terras, já que para a manutenção da agricultura predatória que praticavam, caracterizada pelo esgotamento rápido do solo, era mais interessante poder incorporar a qualquer momento novas terras ao cultivo sem qualquer burocracia, por meio de uma simples invasão. Enquanto fosse possível obter terras devolutas, os fazendeiros manteriam seu padrão de cultivo e a resistência a qualquer medição ou determinação de limites à propriedade. ${ }^{119}$

Assim, os proprietários rurais contribuíram para que a Lei de 1850 não atingisse os efeitos esperados. Se por um lado pediam ao Estado medidas para o desenvolvimento do

\footnotetext{
${ }^{118}$ Carvalho, José Murilo de. A construção da ordem: a elite política imperial. Teatro de Sombras: a política imperial. $3^{\text {a }}$ ed., Rio de Janeiro: Civilização Brasileira, 2003. p. 347.

${ }^{119}$ VAReLA, Laura Beck. Das sesmarias à propriedade moderna: Um estudo de história do direito brasileiro. Rio de Janeiro: Renovar, 2005. p. 153.
} 
crédito rural, em um momento em que o escravo deixava de ser garantia segura para a hipoteca, por outro, não estavam dispostos, nem tinham interesse em demarcar e legitimar suas terras. $^{120}$

No entanto, o fato da política de terras não ter sido um ponto central durante o Império não significa dizer que todos estavam de acordo com os rumos que tomava a propriedade territorial no país. ${ }^{121}$ Alguns políticos, burocratas civis, militares e intelectuais defendiam reformas nas estruturas rurais, criticando as grandes propriedades improdutivas que faziam com que muitas vezes o Estado fosse obrigado a comprar terra para vender aos colonos. $^{122}$

Inclusive uma pequena parte dos comerciantes (entre os quais aqueles que até então se dedicavam à estrutura montada pelo tráfico de escravos) tinha começado a se interessar pela situação da terra, na verdade, até mesmo antes da publicação da Lei de 1850, quando, em 1843, pressionaram o Governo para a elaboração de uma lei que criasse um Registro Geral de Hipotecas. Atente-se para o fato de que muitos deles não estavam interessados em uma política de terras, mas sim em estimular o crédito que se faria com o uso da propriedade como garantia. Assim, os comerciantes apareciam nos dois pólos da negociação: os comerciantes investidores adquiriam empréstimos no banco e os garantiam por meio de imóveis, e os comerciantes especuladores depositavam suas economias na casa bancária e esperavam aumentar seu capital. A certeza do rendimento dependia de grande volume de empréstimos e, obrigatoriamente, de sua garantia.

Apesar de não ser o objetivo central da Lei de 1850, que visava principalmente a obtenção de mão-de-obra estrangeira, centrando-se em terras devolutas e colonização, sua

${ }^{120}$ Carvalho, José Murilo de. A construção da ordem: a elite política imperial. Teatro de Sombras: a política imperial. $3^{\mathrm{a}}$ ed., Rio de Janeiro: Civilização Brasileira, 2003. p. 350.

${ }^{121}$ A fala de VAsconcellos, na sessão de 30 de agosto de 1850, é emblemática quanto ao assunto. Ao defender a análise global das emendas apresentadas pelo Senado ao que viria a ser a Lei de Terras, o deputado tentou demonstrar a importância de se individualizar a propriedade ao afirmar “(...) o projecto, bem longe de confundir e barulhar o direito do proprietário, vai, pelo contrário, dar garantias que até agora lhe faltão, porque se incumbe de dividir e de marcar as terras, offerecer segurança ao posseiro que, contra a legislação do paiz, possuem grande parte de terras ou cultas ou incultas. Como eu, observando o que se tem passado em outros paízes acerca da colonisação e da divisão de terras, entendo que sem estas medidas esses paízes não tem podido progredir prohibindo o trafico de escravos como nós ...". Brasil. Annaes do Parlamento Brazileiro. Câmara dos Srs. Deputados. Sessão de 1850. Tomo Quarto. Rio de Janeiro: Typographa de H. J. Pinto, 1880. p. 732.

${ }^{122}$ Carvalho, José Murilo de. A construção da ordem: a elite política imperial. Teatro de Sombras: a política imperial. $3^{\mathrm{a}}$ ed., Rio de Janeiro: Civilização Brasileira, 2003. p.350. 
efetiva aplicação teria contribuído para a adoção do Registro Geral de Hipotecas. Afinal, para que ele pudesse ser acolhido seria indispensável que fossem determinadas as medidas e limites das terras, além de definido o senhor do domínio, providências previstas no regulamento de 1854.

Em suma, a Lei de Terras e seu regulamento pouco contribuíram para disciplinar a propriedade imóvel ou mesmo seu modo de transmissão. E esse resultado não decorreu unicamente da sua reduzida eficácia, mas também do fato da questão da terra ainda não ser prioridade.

\subsection{Lei Hipotecária N. 1.237 de 1864}

Até meados de 1864, a insegurança no relativo ao crédito e à propriedade não era combatida por meio de qualquer legislação. Quem comprava, não tinha certeza se era o proprietário. Quem emprestava, não tinha certeza se seu crédito estava garantido com a hipoteca.

Quanto à segurança do crédito, a situação ficava ainda mais grave, porque muitos devedores, aproveitando-se da insegurança do sistema, chegavam até mesmo a negar a existência de dívidas que constavam de escrituras públicas. Dessa forma, a propriedade imóvel ficava inteiramente sem crédito, preferindo os credores, nas transações, a garantia pessoal. ${ }^{123}$

Ocorre que a garantia real e a garantia pessoal do crédito são figuras que se complementam. Assim, a ausência de um deles pode prejudicar o desenvolvimento da economia, já que eles são responsáveis por permitirem que capitais fixos sejam utilizados, contribuindo para a circulação de riquezas. O crédito pessoal é baseado unicamente na confiança do credor na pessoa do devedor, estando dessa maneira completamente apartado de uma garantia exterior. Depende de uma legislação específica, que facilite a execução do contrato, já que pressupõe sempre um direito obrigacional. Já o crédito com garantia real é aquele que sempre se referirá a um objeto, ou melhor, a uma propriedade móvel ou imóvel,

${ }^{123}$ Perdigão Malheiros, Augustinho Marques. Repertório ou Índice Alphabetico da Reforma Hypothecaria e sobre sociedades de credito real. Rio de Janeiro: Typographia Nacional, 1865. p. V. 
não importando para o credor as características pessoais do devedor. Depende de uma legislação que regule a propriedade de maneira a desenvolvê-lo e facilitá-lo, uma vez que pressupõe direitos reais como, por exemplo, o domínio e a hipoteca. Por essas diferenças, cada crédito estará presente com mais intensidade em um ramo da economia, ou seja, o pessoal é comum na indústria e no comércio, e o real na agricultura. ${ }^{124}$

Como o Brasil imperial tinha sua economia fundamentada na agricultura, fica claro perceber como a instituição do crédito real era necessária. Afinal, para se desenvolver o campo era indispensável que houvesse a mobilização do solo, ou seja, que os enormes valores dos imóveis pudessem ser representados por títulos (cuja solidez era garantida pelo próprio bem) e circulassem na economia. ${ }^{125}$ Com esses valores, os fazendeiros poderiam fazer os investimentos que desejassem.

Outro fator que dificultava a construção de um sistema hipotecário seguro era o desconhecimento da titularidade do bem. A simples inclusão da clausula constituti nos contratos que visassem à transmissão da propriedade imóvel, não era suficiente para tornar pública a modificação-jurídica. Assim, não havendo certeza de que o devedor era o verdadeiro proprietário do bem, não havia qualquer estímulo para que o credor aceitasse o imóvel como garantia do crédito.

Tentando remediar a situação e objetivando utilizar o imóvel como garantia de empréstimos, deputados liderados por IGnÁCIO JoAquim Barbosa apresentaram, em 1853, um projeto sobre reforma da legislação hipotecária à Câmara dos Srs. Deputados, que o encaminhou para análise a uma comissão especial, de que fazia parte NABUCO DE ArAúJo. No ano seguinte, em seu relatório, o Conselheiro NABUCO, também Ministro da Justiça, complementando o plano de reforma hipotecária propôs a criação de um registro dos atos translativos da propriedade imóvel. Depois de refundir todos os projetos que existiam na

\footnotetext{
124 Teixeira de Frettas, Augusto. Consolidação das Leis Civis. Rio de Janeiro: Typographia Universal de Laemmert, 1865. p. CXXXIX.

${ }^{125}$ Ibidem., mesma página.
} 
Câmara sobre a matéria, o Conselheiro na sessão de 25 de julho de 1854 pediu urgência para apresentar a nova proposta ${ }^{126}$, que passou a ser discutida ainda naquele ano. ${ }^{127}$

Durante as discussões, muitos deputados acompanharam os argumentos de $\mathrm{NABUCO}^{128}$, ressaltando a importância em aprovar a reforma hipotecária. ${ }^{129}$

${ }^{126}$ No relativo ao Registro Geral e transcrição de títulos, o projeto previa:

Do Registro Geral

Art. $8^{\circ}$. O registro geral comprehende:

A transcripção dos títulos de transmissão dos immóveis

A inscrição das hypothecas.

$\S 1^{\circ}$. A transcripção e inscripção devem ser feitas no conservatório das hypothecas da comarca ou comarcas onde forem os bens situados.

$\S 2^{\circ}$. (...)

Da transcripção

Art. $9^{\circ}$. A transcripção entre vivos por título oneroso ou gratuito dos bens suscetíveis de hypotheca $\left(\operatorname{art} .2^{\circ} . \S 1^{\circ}\right.$.) assim como a instituição dos ônus reaes $\left(\right.$ art. $7^{\circ}$ ) não operarão seus effeitos a respeito de terceiros, senão pela transcripção e desde a data della.

$\S 1^{\circ}$. (...)

$\S 2^{\circ}$. A transmissão dos immoveis só terá lugar por escriptura publica, sob pena de nulidade.

$\S 3^{\circ}$. Esta escriptura só póde ser feita por tabellião, pena de nullidade.

$\S 4^{\circ}$. É nula a escriptura, em a qual não fôr inserta a nota da transcripção, como se pratica a respeito dos conhecimentos da sisa.

$\S 5^{\circ}$ e $\S 6^{\circ}(\ldots)$

$\S 7^{\circ}$. A transcripção não induz a prova do domínio, que fica salvo a quem fôr.

$\S 8^{\circ}$. Quando os contractos de transmissão de immoveis, que forem transcriptos, dependerem de condições, estas se não haveráõ por cumpridas ou resolvidas para com os terceiros, se não constarem do registro.

Brasil. Annaes do Parlamento Brazileiro. Câmara dos Srs. Deputados. Sessão de 1854. Tomo Terceiro. Rio de Janeiro: Typographia de - Hyppolito José Pinto \& C. ${ }^{\text {a }}$, 1876. p. 250.

${ }^{127}$ Brasil. Annaes do Parlamento Brazileiro. Câmara dos Srs. Deputados. Sessão de 1856. Tomo Quarto. Rio de Janeiro: Typographia de - Hyppolito José Pinto \& C. ${ }^{\text {a }}$, 1875. p. 205.

${ }^{128} \mathrm{Na}$ sessão de 20 de agosto de 1856 , ao tentar convencer os deputados que não se deveria adiar por mais tempo a reforma hipotecária, NABUCO disse: “... Temos é verdade um registro creado pelo decreto de 1846 para as hypothecas convencionaes, mas este registro não é senão um epigramma; que importa que elle advirta ao emprestador que não ha outras hypothecas convencionaes, se podem occorrer como de emboscada hypothecas privilegiadas e occultas? Temos um registro que nos diz que a propriedade que se vai hypothecar já está hypothecada, mas não temos um registro que nos diga que a propriedade que se vai hypothecar já está alienada, que a propriedade hypothecada foi depois alienada para que o credor possa exercer o seu direito de seqüela e excutir o immovel onde quer que elle se ache". Brasil. Annaes do Parlamento Brazileiro. Câmara dos Srs. Deputados. Sessão de 1856. Tomo Terceiro. Rio de Janeiro: Typographia de - Hyppolito José Pinto \& C. ${ }^{\text {a }}, 1875$. p. 225 e 226.

${ }^{129}$ Na sessão de 22 de agosto de 1856, o deputado Carneiro de Campos ressaltou a importância em se aprovar o projeto apresentado por Nabuco. Dizia o parlamentar: “... Tem-se, senhores, proclamado a necessidade de bancos hypothecários, de bancos ruraes; mas é preciso attender que elles são uma impossibilidade com a actual legislação; se se querem bancos ruraes é preciso tornal-os possiveis, e para isto é preciso que se despreendão, que se soltem esses valores agora fixos em terras, valores que presentemente estão quasi inteiramente presos e inutilizados, com grande prejuízo para o paiz, porque a maior parte da nossa fortuna está em bens ruraes, cujo valor, pela legislação que existe, não póde servir de assento para operações de crédito". BRASIL. Annaes do Parlamento Brazileiro. Câmara dos Srs. Deputados. Sessão de 1856. Tomo Quarto. Rio de Janeiro: Typographia 
Em 1856, após ser aprovado na Câmara dos Deputados, o projeto foi encaminhado para o Senado, no qual foi objeto de estudo pela comissão de legislação. Esta apresentou em 1857 um parecer, oferecendo um projeto substitutivo. O governo imperial ouviu então a opinião de tribunais, faculdades de direito e jurisconsultos, que não chegaram a um acordo sobre qual projeto deveria ser adotado (se o oferecido pela Câmara dos Deputados ou o substitutivo apresentado pela comissão de legislação do Senado). Diante do impasse, o senador ZaCARIAS GóEs requereu na sessão de $1^{\circ}$ de março de 1864 que o Senado sujeitasse novamente os dois projetos ao estudo das comissões de legislação e fazenda, no que foi apoiado. Na sessão de 23 de maio de 1864 as comissões reunidas de legislação e fazenda apresentaram ao Senado o resultado de seu estudo e os debates sobre cada artigo foram iniciados. ${ }^{130}$ Foi apenas na sessão de 12 de julho de 1864, após o término dos debates, que a legislação hipotecária foi remetida à comissão de redação. ${ }^{131}$

As comissões de legislação e fazenda do Senado em nenhum momento trataram da utilidade de uma reforma hipotecária, porque seja para a garantir o crédito por meio de um imóvel, seja para auxiliar o crédito pessoal, esta reforma era, segundo os senadores que as compunham, "incessantemente reclamada pela opinião pública, e todos os annos indicada nos discursos da côroa como uma das primeiras necessidades do paíz". ${ }^{132}$

$\mathrm{Na}$ realidade, o intuito era oferecer segurança ao crédito real imobiliário, complementando a estrutura instituída pelo decreto $n .482$ de 1846 no relativo à publicidade ${ }^{133}$. Como já foi visto, o decreto de 1846 pouco contribuiu para o incremento do crédito, já que

de - Hyppolito José Pinto \& C. a , 1875. p. 255.

${ }^{130}$ Brasil. Annaes do Senado do Império do Brasil, $1^{\text {a }}$ sessão de 1864, vol. III. Rio de Janeiro: Typ. do Correio Mercantil de M. Barreto, Mendes Campos, e Comp.,1864. p. 3 e Annaes do Senado do Império do Brasil, 2a sessão, vol I. Rio de Janeiro: Typ. do Correio do Comercio Mercantil de M. Barreto, Mendes Campos, e Comp., 1864. p. 48.

${ }^{131}$ Brasil. Annaes do Senado do Império do Brasil, $2^{a}$ sessão de 1864, vol III. Rio de Janeiro: Typ. do Correio do Comercio Mercantil de M. Barreto, Mendes Campos, e Comp., 1864. p. 56.

${ }^{132}$ Brasil. Annaes do Senado do Império do Brasil, $2^{a}$ sessão de 1864, vol I. Rio de Janeiro: Typ. do Correio do Comercio Mercantil de M. Barreto, Mendes Campos, e Comp., 1864. p. 48.

${ }^{133}$ Para as Comissões de legislação e fazenda do Senado, a transcrição surgiu para complementar o registro da hipoteca criado pelo decreto de 1846, que era "imperfeito e ilógico, porque previne uma espécie de estellionato que consiste na hypotheca do immovel já hypothecado, mas não previne outra espécie de estellionato mais fatal como é a hypotheca do immovel já alheado". Brasil. Annaes do Senado do Império do Brasil, 2ª sessão de 1864, vol I. Rio de Janeiro: Typ. do Correio do Comercio Mercantil de M. Barreto, Mendes Campos, e Comp., 1864. p. 49. 
não previa a publicidade da transmissão dos bens imóveis, primeira condição para um bom sistema hipotecário.

Para ZACARIAS DE GóES, um bom sistema hipotecário precisava preencher duas exigências: primeiro, garantir àquele que oferece seu dinheiro que o proprietário a quem ele empresta é legitimamente dono do imóvel hipotecado e dele pode dispor; segundo, que o pagamento tornar-se-ia efetivo sem qualquer diferença no valor hipotecado, ou seja, sem que houvesse desconto de quantias que não poderiam ter entrado nas contas do credor porque eram, ao tempo do contrato, por ele completamente desconhecidas. Apenas quando a legislação cumprisse essas condições é que estabelecimentos que oferecem créditos a baixo custo e longos prazos poderiam ser criados e desenvolvidos, atendendo à necessidade da propriedade imóvel e principalmente da agricultura do país. ${ }^{134}$

O senador confirmava essa necessidade palpitante, dizendo que o governo recebia propostas no sentido de criar estabelecimentos que emprestassem dinheiro, inclusive com participação de capital estrangeiro, mas sempre era avisado de que seria fundamental que primeiro se alterasse a legislação hipotecária. ${ }^{135}$

O projeto apresentado em 1854 pelo Ministro Nabuco deu origem, depois de algumas alterações, à Lei Hipotecária n. 1.237 de 24 de setembro de 1864.

A Lei de 1864 estabeleceu a transcrição, atendendo aos reclamos pelo crédito territorial ${ }^{136}$ que exigia do regime hipotecário uma base firme de publicidade para não cair

${ }^{134}$ Esta foi a opinião expressada pelo Senador Zacarias de Góes na sessão de $1^{\circ}$ de março de 1864 , quando requereu que o projeto de lei hipotecária retornasse as comissões de legislação e fazenda, a fim de que elas apresentassem um parecer sobre o assunto. Essas duas exigências para um bom sistema hipotecário também eram levantadas por Teixeira de Freitas, como será visto adiante. Brasil. Annaes do Senado do Império do Brasil, $1^{\mathrm{a}}$ sessão, de 1864, vol. III. Rio de Janeiro: Typ. do Correio Mercantil de M. Barreto, Mendes Campos, e Comp.,1864. p. 3.

${ }^{135}$ Brasil. Annaes do Senado do Império do Brasil, $1^{\text {a }}$ sessão de 1864, vol. III. Rio de Janeiro: Typ. do Correio Mercantil de M. Barreto, Mendes Campos, e Comp.,1864. p. 3.

${ }^{136}$ A necessidade de se reformar o sistema hipotecário não foi apenas sentida pelos deputados. A mudança legislativa também era pleiteada por alguns fazendeiros, como fica claro na análise da sessão parlamentar de 6 de abril de 1864, que tratou da Lei Hypothecaria e do crédito rural:

"O Sr. Silveira Lobo pede a palavra para apresentar uma representação de 372 fazendeiros que reclamão providencias em favor da lavoura, e requer que seja nomeada uma commissão especial para com urgência apresentar um projecto de lei hypothecaria e de credito rural.

Vem à mesa, é lido, apoiado, e approvado sem debate o seguinte requerimento:

$<$ Requeiro a nomeação de uma commissão especial para confeccionar um projecto de lei hypothecaria e de credito rural - Silveira Lobo.> 
novamente nos erros da lei orçamentária ${ }^{137}$. Com a transcrição, tornou-se conhecida de qualquer interessado a situação do imóvel, ou seja, quem era seu proprietário e se ele estava gravado por algum ônus real. Ao lado disso, a lei regularizou a inscrição das hipotecas, prevendo esse direito de garantia sobre bens imóveis, mas vetando-o sobre os bens móveis.

Mas também havia aqueles que achavam dispensável a transcrição dos atos translativos de domínio para assegurar mutuantes e adquirentes sobre a situação do imóvel, ou seja, a informação a respeito de seu proprietário atual e se havia hipoteca ou alienação anterior. Para a Comissão do Senado, que apresentou em 1854 parecer sobre o projeto Nabuco, essa publicidade já existia no sistema brasileiro. O registro previsto pelo Ministro seria uma formalidade "incommoda, dispendiosa e talvez desnecessária", já que o mesmo resultado era obtido consultando os cartórios de escrituras públicas e os livros fiscais. Pelo primeiro encontrar-se-iam todas as transmissões de imóveis e pelo segundo todos os atos de alienação, uma vez que estes só possuíam valor jurídico após o pagamento do respectivo imposto. Assim, para a Comissão, bastaria que o Estado concentrasse esses cartórios e registros fiscais na localidade do imóvel para que todos tivessem conhecimento de tais atos. ${ }^{138}$

No entanto, a Lei Hipotecária de 1864 desobedeceu às orientações da Câmara dos Senadores, no que se referia à publicidade, uma vez que se fazia necessário um registro do qual qualquer interessado pudesse obter com facilidade certidões e esclarecimentos, o que não ocorria com os livros de notas dos tabeliães. ${ }^{139}$

Brevemente, pode-se afirmar que a lei instituiu o registro geral para a transcrição dos títulos de transmissão, por atos inter vivos, de imóveis suscetíveis de hipoteca e a instituição de ônus reais (art. $7^{\circ}$ ), que a transferência passou a não operar a respeito de

O Sr. Presidente nomêa para a referida commissão os Srs. Silveira Lobo, Dantas, Ferreira de Moura, Paula Souza e Jacobina.”. Brasil. Annaes do Parlamento Brazileiro. Camara dos Srs. Deputados. Sessão de 1864. Tomo Quarto, 1864. p. 44.

${ }^{137}$ Segundo Perdigão Malheiros, "Esta reforma tem como objetivo o desenvolvimento do credito predial ou real. Ou seja, o fim da lei é mobilizar a propriedade imóvel tornando-a um capital produtivo e não amortizado como se acha hoje. Assim, criar novas forças e elementos de riqueza pública e privada, auxiliando a lavoura, nossa principal fonte de produção, que geme debaixo do peso, em geral, de dívidas usurarias e esmagadoras". Repertório ou Índice Alphabetico da Reforma Hypothecaria e sobre sociedades de credito real. Rio de Janeiro: Typographia Nacional, 1865. p. V.

${ }_{138}$ VeIGA, Didimo Agapito da. Direito Hypothecario commentario ao decreto 169-A de 19 de janeiro de 1890. Rio de Janeiro: Laemmert \& C. Editores, 1899. p. 257 e 258.

${ }^{139}$ Ibidem., p. 258. 
terceiros senão pela transcrição e desde sua data $\left(\operatorname{art.} 8^{\circ}\right)$, que a transcrição não induzia prova de domínio (art. $8^{\circ}, \S^{\circ}$ ) e que a lei dispensou do ato de transcrição as transmissões causa mortis (seu regulamento, decreto n. 3.453 de 1853, ampliou a falha ao não exigir a transcrição dos atos judiciários). Ainda, a lei n. 1.237 aboliu as hipotecas que não fossem por ela estabelecidas $\left(\operatorname{art} .1^{\circ}\right.$ ), restringiu o objeto da hipoteca aos bens imóveis, que enumerou (art. $2^{\circ}$ ), exigiu a escritura pública como substância da hipoteca convencional (art. $4^{\circ}, \S 6^{\circ}$ ), instituiu a prenotação (uma anotação preventiva para garantir a prioridade em favor das hipotecas que dependessem de especialização - art. 9, §27), enumerou, taxativamente, os ônus reais (art. $6^{\circ}$ ), sujeitando-os a inscrição. Em suma, instituiu o Registro de Imóveis. ${ }^{140}$

Entre todos os artigos citados, vale fazer um breve comentário a respeito do artigo $7^{\circ}$, uma vez que por se referir ao "título" ${ }^{141}$, possibilita analisar como caminhava a legislação relativa a esta matéria. ${ }^{142} \mathrm{O}$ artigo $7^{\circ}$ previa:

"O registro geral comprehende:

A trancripção dos títulos da transmissão dos immoveis susceptíveis de hypotheca e a instituição dos ônus reais."

Por muito tempo, foram as Ordenações Filipinas que regularam as escrituras públicas e os instrumentos particulares. Na verdade, essa legislação apenas previa entre suas regras processuais civis, a possibilidade de provar a existência de um contrato por meio desses instrumentos, exigindo um ou outro dependendo do valor do bem móvel ou imóvel envolvido (Livro 3, Título LIX).

Os primeiros projetos referentes à reforma da legislação hipotecária apresentados pelo Conselheiro Nabuco na Câmara dos Srs. Deputado, mostram a preocupação do jurista em impor que todas as transmissões de imóveis fossem feitas por meio de escritura pública,

\footnotetext{
${ }^{140}$ Não se esqueça de que o Registro Geral de Hipotecas já havia sido criado pela Lei Orçamentária de 1843.

${ }^{141}$ Segundo Luiz Egon Richter, título "é todo e qualquer documento que contempla no seu bojo direito a ser constituído, desconstituído ou declarado ou, ainda, meros atos e fatos que possam de uma forma ou outra repercutir no registro, independentemente da produção de efeitos". A trajetória do título no Registro de Imóveis: considerações gerais. Revista de Direito Imobiliário, São Paulo, n 56, ano 27, p.48, 2004.

${ }^{142} \mathrm{O}$ estudo do título é importante na medida em que a transferência da propriedade imóvel inter vivos é um ato complexo, envolvendo tanto o título quanto o registro. Sendo assim, com o intuito de complementar o objeto central da dissertação sem expandi-lo demasiadamente, buscar-se-á indicar como caminhava a legislação sobre os títulos.
} 
elaborada por tabelião, prevendo, em caso de desobediência, a nulidade do negócio (art. $9^{\circ}$, $\S \S 2^{\circ}$ e $3^{\circ}$ do projeto de 1854 , transcrito na nota de rodapé n. 130).

Porém, após inúmeros debates, os parágrafos que exigiam a obrigatoriedade da escritura pública para a transferência de todos os bens imóveis foram abandonados, dando lugar ao parágrafo $2^{\circ}$ do artigo $8^{\circ}$ da lei hipotecária de 1864 , que permitia apenas excepcionalmente, a transmissão por escrito particular. Diz-se excepcionalmente, porque a regra continuava sendo a escritura pública, cabendo instrumento particular somente nos casos em que a legislação permitisse e desde que constasse o reconhecimento da firma dos contratantes pelo tabelião e o conhecimento da sisa (imposto instituído pela lei n. 269 de 1835 que atualmente corresponderia ao imposto sobre a transmissão de bens imóveis inter vivos ITBI).

\section{O parágrafo $2^{\circ}$ do artigo $8^{\circ}$ previa:}

\footnotetext{
"Quando a transmissão fôr por escripto particular, nos casos em que a legislação actual o permitte, não poderia esse escripto ser transcripto, se delle não constar a assignatura dos contrahentes reconhecida per tabellião e o conhecimento da siza".
}

Entre o projeto apresentado por Nabuco, em 1854, e sua conversão em lei, em 1864, surgiu, em 1855, a lei n. 840, de 15 de setembro, que em um de seus artigos tratava sobre a escritura pública; apenas em um de seus dispositivos, pois a lei tinha como intuito fixar despesas e orçar receitas para o exercício de 1856-1857.

“Art. 11. A compra e venda de bens de raiz, cujo valor exceder de duzentos mil réis, será feita por escriptura publica, sob pena de nullidade."

A partir de então, não mais se aplicava o limite determinado pelas Ordenações Filipinas, ou seja, de exigir escritura pública para a compra e venda que recaísse sobre imóvel e cujo valor superasse quatro mil réis. Relacionando o novo limite para os contratos de compra e venda de bens de raiz com o $\S 2^{\circ}$ do artigo $8^{\circ}$ da lei hipotecária, afere-se que, quando a obrigação envolvia valor superior a duzentos mil réis, era obrigatória a escritura pública. Nos casos em que a quantia era inferior, cabia escrito particular, desde que reconhecida as firmas dos contraentes por tabelião e recolhida a sisa. 
Para Lafayette Rodrigues Pereira, o termo "título" também englobava, além da escritura pública e do escrito particular, os atos judiciais que transferissem o domínio sobre a propriedade, como a adjudicação e a arrematação. Como será visto mais adiante, esse entendimento não foi acompanhado pelos legisladores que elaboraram o regulamento da lei hipotecária de $1864 .{ }^{143}$

Após essa breve digressão sobre quais seriam os títulos a que o artigo $7^{\circ}$ referia-se, passa-se ao estudo minucioso do próximo dispositivo, o oitavo. Os motivos que levam à sua análise detalhada são outros, e centram-se principalmente no fato do artigo $8^{\circ}$ ter sido por muito tempo objeto de discussões. O caput do artigo $8^{\circ}$ dispunha:

Art. $8^{\circ}$. A transmissão entrevivos por titulo oneroso ou gratuito dos bens susceptiveis de hyphotecas assim como a instituição dos ônus reaes não operão seus effeitos a respeito de terceiro, senão pela transcripção e desde a data della.

Por meio de uma interpretação literal compreende-se que, entre os contratantes prevalecia a transmissão feita por escritura pública ou por escrito particular, seguida da tradição. Já, perante terceiros, o contrato somente produzia efeitos depois de transcrito. Além de ser esta a interpretação literal, era também a teleológica, uma vez que o criador do projeto que resultou na lei, Nabuco de Araújo, na sessão de 22 de agosto de 1856 tornou claro esse entendimento. ${ }^{144}$

Na mesma sessão, o deputado BAndeIRA de Mello havia arrolado o que ele acreditava serem omissões do projeto de lei; entre elas alertou para o fato de que no texto não ficava claro se a transmissão dos imóveis era válida entre os contratantes, mesmo se não inscrita. Diante da crítica, NABUCO DE ARAúJo asseverou que o próprio artigo $9^{\circ}$ do projeto respondia essa dúvida, esclarecendo que o dispositivo a que ele se referia era aquele que, após os debates legislativos, deu origem ao artigo $8^{\circ}$, ou seja, que a transmissão inter vivos por título oneroso ou gratuito não operava seus efeitos senão pela transcrição e desde a data dela. Para NABUCO, o dispositivo era claro e, interpretando-o a contrario sensu, compreendia-se que

\footnotetext{
${ }^{143}$ Direito das Cousas. Rio de Janeiro: Jacintho Ribeiro dos Santos, [188?]. p. 122 e 123/vol.I.

${ }^{144}$ Brasil. Annaes do Parlamento Brazileiro. Câmara dos Srs. Deputados. Sessão de 1856. Tomo Quarto. Rio de Janeiro: Typographia de - Hyppolito José Pinto \& C., 1875. p. 252.
} 
a transferência do imóvel produzia por si só seus efeitos, independentemente de inscrição, perante os contratantes. ${ }^{145}$

Contudo, apesar da possibilidade da interpretação literal e teleológica, a redação do dispositivo foi explicada de maneira diferente por três correntes que surgiram:

Havia uma primeira, defendida pelo Conselheiro Andrade Figueira, Rodrigues Tôrres e, modernamente por Penaforte Mendes, Ribeiro de Souza e outros, para a qual não era por meio da transcrição que a propriedade mudava de domínio, e que ela nem era necessária para que o direito do adquirente fosse oposto a terceiros. Ainda, o terceiro da lei era apenas o credor hipotecário. ${ }^{146}$

A segunda corrente era sustentada por Augustinho Marques Perdigão Malheiros ${ }^{147}$, João Afonso Borges ${ }^{148}$, Francisco Bertino de Almeida Prado ${ }^{149}$ e, recentemente, por Varela e, para esses, a transmissão da propriedade ocorria com a tradição. A transcrição servia apenas para o direito do adquirente ser oposto perante terceiros, ou seja, aqueles que tivessem adquirido a propriedade do mesmo vendedor e tivessem registrado os respectivos títulos. A lei não dispunha sobre qualquer outro terceiro, muito menos sobre um mero usurpador. Dessa forma, cabia aos contratantes decidir se desejavam obter maior segurança nas transações e garantir a eficácia perante terceiros, transcrevendo ou não o título correspondente ao negócio. Em outras palavras, como o ato de transcrição não era modo de aquisição da propriedade

\footnotetext{
${ }^{145}$ Brasil. Annaes do Parlamento Brazileiro. Câmara dos Srs. Deputados. Sessão de 1856. Tomo Quarto. Rio de Janeiro: Typographia de - Hyppolito José Pinto \& C., 1875. p. 253.

${ }^{146}$ Borges, João Afonso, O Registro Torrens no Direito Brasileiro. São Paulo: Saraiva, 1960. p. 16.

${ }^{147}$ Ao falar das idéias capitais da reforma hipotecária (ou seja, da lei n. 1.237 de 1864 e seus regulamentos) o autor afirmou "A transcripção ou registro das acquisições de bens capazes de hypotheca, assim como da instituição dos onus reaes reconhecidos pela Lei da reforma, importa a publicidade de taes acquisições e instituições, para que possa como que servir de cadastro da propriedade immovel, e evitar sorprezas contra os credores hypothecarios, que ignorassem em boa-fé taes actos; e ao mesmo tempo garantir os adquirentes contra terceiros. Todavia esse registro não faz prova de dominio, que fica a salvo a quem de direito fôr". Em seguida completava, "A falta de registro da hypotheca, ou da acquisição, não prejudica os contrahentes entre si. Esse registro só resguarda contra terceiros. Entre as proprias partes o contracto surte todos os seus effeitos, independente delle". Repertório ou Índice Alphabetico da Reforma Hypothecaria e sobre sociedades de credito real. Rio de Janeiro: Typographia Nacional, 1865. p. VI.

${ }^{148}$ O Registro Torrens no Direito Brasileiro. São Paulo: Saraiva, 1960. p.17 e 18.

${ }^{149}$ Segundo o autor "o adquirente com o seu título, em vista do transmitente, é proprietário do imóvel, podendo dele usar por si próprio, mas desde que pretenda transmiti-lo ou sobre ele constituir qualquer especie de onus, isto é, desde que se ponha em contacto com terceiros ou tenha necessidade de comparecer em juizo, é preciso realizar a perfeição da tradição, que se opera pela inscrição e assim tornar-se disponível o seu direito". Transmissão da propriedade imóvel. São Paulo: Saraiva \& Comp.Editores, 1934. p. 121.
} 
imóvel, ele dependia da vontade das partes. Essa era a opinião da maioria dos juristas como, por exemplo, Augustinho Marques Perdigão Malheiros ${ }^{150}$, João Afonso Borges ${ }^{151}$, Francisco Bertino de Almeida Prado ${ }^{152}$ e, recentemente, Varela. ${ }^{153}$

A terceira corrente era defendida por LAFAYETTE, para quem a transcrição tanto servia para transmitir a propriedade imóvel entre os contratantes, quanto perante terceiros. Nos casos em que a lei dizia "a respeito de terceiros" em sentido absoluto, valia qualquer terceiro sem nenhuma restrição ou condição. Dessa forma, antes da transcrição, o adquirente não podia reivindicar o imóvel, nem de um terceiro que possuísse justo título, nem de um mero usurpador. Afinal, como o domínio era um direito oponível erga omnes, se não existisse perante terceiros, também não haveria entre as partes contratantes. ${ }^{154}$

Segundo o mesmo autor, nesse ponto o direito francês diferenciava do brasileiro. A lei francesa de 23 de março de 1855 negava os efeitos do domínio antes da transcrição aos terceiros que tivessem direitos sobre o imóvel em conformidade com a lei. Dessa maneira, continuava a lógica de que, independentemente da transcrição, o domínio transferia-se em relação a terceiros, que não tinham direitos sobre o imóvel, conservados pela lei, como são os usurpadores, os credores quirografários do alienante e os que não registraram seus títulos. ${ }^{155}$

\footnotetext{
${ }^{150}$ Ao falar das idéias capitais da reforma hipotecária (ou seja, da lei n. 1.237 de 1864 e seus regulamentos) Perdigão Malheiros afirmou "A transcripção ou registro das acquisições de bens capazes de hypotheca, assim como da instituição dos onus reaes reconhecidos pela Lei da reforma, importa a publicidade de taes acquisições e instituições, para que possa como que servir de cadastro da propriedade immovel, e evitar sorprezas contra os credores hypothecarios, que ignorassem em boa-fé taes actos; e ao mesmo tempo garantir os adquirentes contra terceiros. Todavia esse registro não faz prova de dominio, que fica a salvo a quem de direito fôr". Em seguida completava, "A falta de registro da hypotheca, ou da acquisição, não prejudica os contrahentes entre si. Esse registro só resguarda contra terceiros. Entre as proprias partes o contracto surte todos os seus effeitos, independente delle". Repertório ou Índice Alphabetico da Reforma Hypothecaria e sobre sociedades de credito real. Rio de Janeiro: Typographia Nacional, 1865. p. VI.

${ }^{151}$ O Registro Torrens no Direito Brasileiro. São Paulo: Saraiva, 1960. p.17 e 18.

${ }^{152}$ Conforme escreve o autor "o adquirente com o seu título, em vista do transmitente, é proprietário do imóvel, podendo dele usar por si próprio, mas desde que pretenda transmiti-lo ou sobre ele constituir qualquer especie de onus, isto é, desde que se ponha em contacto com terceiros ou tenha necessidade de comparecer em juizo, é preciso realizar a perfeição da tradição, que se opera pela inscrição e assim tornar-se disponível o seu direito". Transmissão da propriedade imóvel. São Paulo: Saraiva \& Comp.Editores, 1934. p. 121.

${ }^{153}$ Segundo a autora, "No sistema da Lei de 1864, o ato da transcrição ainda dependia da vontade das partes, as quais poderiam optar por uma maior segurança nas transações e garantir a eficácia perante terceiros, transcrevendo ou não o título correspondente ao negócio dispositivo no respectivo registro". Das Sesmarias à propriedade moderna: um estudo de história do direito brasileiro. Rio de Janeiro: Renovar, 2005. p. 180.

${ }^{154}$ Direito das Cousas. Rio de Janeiro: Jacintho Ribeiro dos Santos, [188?]. p. 116/vol.1.

${ }^{155}$ Ibidem., p. 116 e 117.
} 
Assim, LAFAYETTE entendia que para a lei brasileira admitir a transferência do domínio somente entre as partes antes da transcrição, e perante todos os terceiros depois dela, seria necessário desvirtuar o conceito de domínio que existia na ciência do direito. Como não havia qualquer lei prevendo a mudança de sua definição, não havia como aceitar uma transferência de domínio que não fosse erga omnes. ${ }^{156}$

Referindo-se ao direito francês (e não ao artigo $8^{\circ}$ da Lei Hipotecária de 1864) Augusto Teixeira de Freitas apresenta em sua obra "Consolidação das Leis Civis" o mesmo pensamento de Lafayette. Para o autor, não era possível concordar com aqueles que acreditavam que a transcrição nos registros só era necessária em relação a terceiros e não em relação às partes. Afinal uma vez reconhecido um ato externo para a transmissão da propriedade imóvel, não havia motivo algum para que o sistema funcionasse de maneira diversa para os contratantes. Ademais, antes da transcrição, as regras que regulavam os direitos obrigacionais eram suficientes para solucionarem qualquer conflito. ${ }^{157}$

O autor ainda dizia que era estranho imaginar que o direito real só existia com um indivíduo, pois o domínio era um direito absoluto e sem este caráter ele não existia. Ainda, se o vendedor por meio do contrato transmitisse o domínio, ele não poderia transferir a coisa uma segunda vez, pois não tinha mais o domínio, isso valia mesmo nos casos em que o comprador não tivesse feito a transcrição. ${ }^{158}$

Se para dirimir dúvidas quanto ao sentido do artigo $8^{\circ}$ da Lei, recorresse-se não só às concisas explicações feitas por Nabuco de Araújo ao colega BandeIRA de Mello, mas também aos argumentos oferecidos pelas Comissões de legislação e fazenda do Senado para a adoção do artigo $8^{\circ}$, corroborar-se-ia as idéias da segunda corrente.

Conforme o entendimento das Comissões, a transcrição nada mais era que a perfeição da tradição que pelas Ordenações Filipinas era necessária para a transmissão de domínio. Mas para que esse domínio fosse respeitado por terceiros, era necessário que eles conhecessem sua existência. Assim, a transcrição era facultativa, só era realizada se o adquirente desejasse que a transmissão surtisse efeitos perante terceiros. Porém, como a

\footnotetext{
${ }^{156}$ Ibidem., p. 117.

${ }^{157}$ Consolidação das Leis Civis. Rio de Janeiro: Typographia Universal de Laemmert, 1865. p. CLXIII.

${ }^{158}$ Consolidação das Leis Civis. Rio de Janeiro: Typographia Universal de Laemmert, 1865. p. CLXIII.
} 
transcrição não induzia prova de domínio, ela só dizia aos terceiros que o contrato existia, não que ele era válido. Para as Comissões, a transcrição com o passar do tempo e a ocorrência de mutações, levaria à aproximação do registro e da certeza do domínio ${ }^{159}$, ou seja, com o tempo, obter-se-ia a segurança da propriedade.

A posição das Comissões do Senado de previrem no artigo $8^{\circ}$ da Lei Hipotecária, que a propriedade imóvel transferia-se pelo simples contrato e a transcrição servia apenas para que terceiros conhecessem a existência da mutação, é mais uma vez comprovada quando elas afirmam que a figura da transcrição teve por si a autoridade da França (lei de 23 de março de 1855), da Bélgica (lei de 16 de setembro de 1851) e de outros paises civilizados. ${ }^{160}$ Em outras palavras, nessas legislações, a transcrição serve apenas para tornar os efeitos da aquisição válidos perante terceiros.

Dessa maneira, não há dúvidas de que a segunda corrente acima indicada acompanhou o entendimento das Comissões de Legislação e Fazenda do Senado para interpretar o artigo oitavo da lei.

Acontece que, a terceira corrente também utilizou o parecer das Comissões de Legislação e Fazenda para justificar que a transcrição era fundamental para transferir a propriedade imóvel entre os contratantes e perante terceiros.

Como já foi visto as Comissões afirmaram:

“1 ${ }^{\circ}$ Essa transcripção não é senão a perfeição da tradição que entre nós é necessária para operar-se o domínio (Ord. Liv. 4 Tít. $7^{\circ}$ princ.)"161

Com fundamento apenas nesse ponto do parecer e excluindo todo o restante, os juristas da terceira corrente entenderam que a transcrição nada mais era do que uma tradição solene, sendo assim obrigatória para a mutação patrimonial. Afinal, nas Ordenações Filipinas, inclusive citadas pelas Comissões, era por meio da tradição que o bem imóvel era transferido entre as partes contratantes, assim, antes dela, o domínio continuava pertencendo ao alienante.

\footnotetext{
${ }^{159}$ Brasil. Annaes do Senado do Império do Brasil, 2a sessão de 1864, vol I. Rio de Janeiro: Typ. do Correio do Comercio Mercantil de M. Barreto, Mendes Campos, e Comp., 1864. p. 49.

${ }^{160}$ Brasil. Annaes do Senado do Império do Brasil, 2a sessão de 1864, vol I. Rio de Janeiro: Typ. do Correio do Comercio Mercantil de M. Barreto, Mendes Campos, e Comp., 1864. p. 49.

${ }^{161}$ Brasil. Annaes do Senado do Império do Brasil, 2a sessão de 1864, vol I. Rio de Janeiro: Typ. do Correio do Comercio Mercantil de M. Barreto, Mendes Campos, e Comp., 1864. p. 49.
} 
Restringir-se unicamente a um ponto do parecer para tentar entender a posição das Comissões de Legislação e Fazenda do Senado parece um pouco perigoso, no entanto, foi o que fizeram juristas como LafayetTE ${ }^{162}$ e SoRIANo Neto ${ }^{163}$.

Como não houve consenso nem mesmo quanto à posição das Comissões do Senado, a divergência acerca da interpretação do artigo $8^{\circ}$ da Lei Hipotecária de 1864 manteve-se, apenas sendo solucionada com a promulgação do decreto n. 3.453 de 26 de abril de 1865, que em seu art. 257 expressamente determinou:

"Art. 257. Até a transcripção, os referidos actos são simples contractos que só obrigão as partes contractantes."

Com o novo artigo entendeu-se que, se antes da transcrição o ato era considerado um simples contrato e o contrato não transferia domínio, havia apenas direitos obrigacionais entre os contratantes.

Mas esse entendimento não era unânime. Segundo Lacerda de Almeida, a previsão do art. 257 criou uma antinomia no sistema jurídico brasileiro. Afinal, se o art. $8^{\circ}$ (art. 256 do decreto de 1865) era expresso em dispor que a transmissão não gerava efeitos perante terceiros, o lógico seria entender que, sem a transcrição, a propriedade transferia-se apenas entre as partes contratantes. Assim, havia uma contradição entre o art. $8^{\circ}$ e o art. 257 para o qual, antes da transcrição, os atos eram simples contratos, não levando à transferência do imóvel. O autor questionava a utilidade de se prever "a respeito de terceiros", se a transmissão não transcrita não operava efeito translatício nenhum, nem mesmo entre as partes. ${ }^{164}$

Era pertinente a observação de Lacerda DE AlmeidA, para quem o ideal seria que o legislador brasileiro tivesse se afastado da influência francesa também no momento de redigir o dispositivo, retirando do art. 256 do decreto de 1865 o termo "terceiros", completamente desnecessário que acabou por proporcionar discussões desnecessárias. ${ }^{165}$

\footnotetext{
${ }^{162}$ Direito das Cousas. Rio de Janeiro: Jacintho Ribeiro dos Santos, [188?]. p. 117/vol.1.

${ }^{163}$ Publicidade Material do Registro Imobiliário: efeitos da transcrição. Recife: [s.n.], 1940. p. 14.

${ }^{164}$ Direito das Cousas. Rio de Janeiro: Jacintho Ribeiro dos Santos, 1908. p. 205.

165 “Art. 256. Não opera seus effeitos a respeito dos terceiros senão pela transcripção e desde a data della, a transmissão entre vivos por titulo oneroso ou gratuito dos immoveis susceptíveis de hypoteca (art. $8^{\circ}$ da lei)".
} 
Com a interpretação do artigo $8^{\circ}$ consolidada, pode-se dizer que apesar da Lei Hipotecária de 1864 não ter se filiado a nenhum sistema registrário existente, o alemão ou o francês ${ }^{166}$, e ter preferido um regime transacional entre os dois, ela se aproximou do sistema germânico ao exigir para a transferência da propriedade à transcrição. Por outro lado, avizinhou-se do sistema francês ao repelir o princípio da publicidade material, em qualquer de suas modalidades, ou seja, o princípio da eficácia jurídica formal ou o da fé pública. ${ }^{167}$

Por mais que as Comissões de Legislação e Fazenda do Senado acreditassem que a transcrição de sucessivas mutações patrimoniais levaria à certeza da propriedade, percebe-se pelo conjunto dos acontecimentos que essa figura jurídica não foi instituída com o objetivo de determinar a propriedade imóvel. Sem dúvida, ela surgiu unicamente para proporcionar a publicidade das modificações jurídico-reais, pressuposto indispensável para a criação de um regime hipotecário que garantisse estabilidade e segurança ao crédito garantido por um bem imóvel. Em outros termos, a transcrição só foi prevista em lei porque a sociedade comercial exigia um bom sistema hipotecário e, para isso, era fundamental a existência de um registro que tivesse informações atualizadas sobre quem era o titular do bem.

No entanto, em um país com uma desordenada situação das terras, descobrir quem era o proprietário não era tarefa das mais fáceis. Para tal, era necessário fazer a genealogia da propriedade, resgatando título após título (se o proprietário tivesse obedecido às orientações da Lei de Terras, já teria o título de domínio). Mesmo que a cadeia de sucessões fosse montada, chegava-se ao provável titular, raramente se concluía pela absoluta certeza da titularidade.

Ao prever a figura da transcrição, a Lei Hipotecária não contribuiu para a descoberta do real proprietário do bem, uma vez que aquele ato apenas impunha ao adquirente os mesmos direitos do alienante, não corrigindo possíveis vícios. Assim, a lei não concorreu para a certeza do domínio, pois não possibilitava a determinação do verdadeiro titular.

A importância da transcrição estava no fato de que ela tornava público o estado em que a propriedade encontrava-se, dificultando estelionatos, como as alienações e hipotecas duplicadas. Por ser um mero instrumento de publicidade formal, a transcrição não fornecia

\footnotetext{
${ }^{166}$ Os sistemas registrários serão objeto de estudo no próximo capítulo.

${ }^{167}$ Este princípio será explicado quando do estudo do sistema registral alemão (item 3.2).
} 
prova absoluta ou mesmo relativa de domínio (força probante). Esta ausência de presunção jurídica obrigava o reivindicante a ter que provar sempre que necessário que tinha adquirido a propriedade do verdadeiro titular. Como a legitimidade do domínio do alienante dependia da de seu antecessor, o interessado deveria pesquisar a genealogia da propriedade, sua filiação de título em título, até atingir o ponto definitivo que se consumava o usucapião. Só então se firmava o direito de propriedade. Assim, a única maneira idônea de purificar o domínio era por meio do usucapião, pelos meios derivados de aquisição de propriedade era difícil ou impossível de ser feito. ${ }^{168}$

Quanto aos encargos, sua presença no registro público não significava muita coisa, eles podiam ser anulados por vícios intrínsecos dos contratantes, vícios de forma ou incapacidade civil de uma das partes. ${ }^{169}$

Para Soriano Neto, como a transcrição não tinha força de verdadeiro título, ou seja, não sanava suas imperfeições, ela apenas atribuía ao adquirente os direitos do alienante. Assim, realizava uma tarefa que era comum a qualquer registro geral, cadastro ou recenseamento. ${ }^{170}$

Com efeito, a eficiência do registro é tanto maior quanto mais preciso for o direito dominical fornecido pela última transcrição, ou seja, quanto maior a confiança de que o vendedor do imóvel é realmente o verdadeiro proprietário. Afinal, não é possível falar em segurança na alienação, quando o sistema registral apenas indica o último adquirente do imóvel, deixando para posterior análise judicial a efetividade deste direito real.

Como a transcrição não induzia prova de domínio, a segurança jurídica que a publicidade oferecia era ilusória. Se considerado o interesse primordial do legislador de 1864, que era o de oferecer segurança ao crédito territorial, teve pouca importância a publicidade da aquisição do imóvel. É claro que para um perfeito regime hipotecário, é fundamental que haja

${ }^{168}$ Soriano de souza Neto, José. Publicidade Material do Registro Imobiliário: efeitos da transcrição. Recife: [s.n.], 1940. p. 20.

${ }_{169}$ Teixeira de Freitas, Augusto. Consolidação das Leis Civis. Rio de Janeiro: Typographia Universal de Laemmert, 1865. p. CLXVII.

${ }^{170} \mathrm{O}$ mesmo autor apresenta um exemplo elucidativo. Se "A" transfere imóvel que não é de sua propriedade a "B", a tradição apenas passa a posse do bem a "B", não corrigindo qualquer vício. Da mesma forma a transcrição, que servirá unicamente para proporcionar publicidade a esta situação. Publicidade Material do Registro Imobiliário: efeitos da transcrição. Recife: [s.n.], 1940. p. 18. 
o registro da circulação do imóvel; no entanto, esse registro será ineficiente se toda vez que o proprietário desejar garantir um empréstimo por meio da hipoteca de seu imóvel, tiver que provar que o bem lhe pertence.

Fornecer ou não força probante à transcrição já havia gerado uma série de discussões na Câmara dos Deputados quando da elaboração desta Lei Hipotecária. Assim, a escolha em fazer com que a transcrição não provasse o domínio não foi aleatória, mas sim fruto de um pensamento realista encabeçado pelo Conselheiro NABUCO, que enfrentou todas as pressões oriundas do parecer contrário à matéria emitido pela Comissão Especial responsável por analisar o projeto. ${ }^{171}$

Como exemplo, pode-se citar as palavras do deputado Barreto Pedroso que, na sessão de 27 de julho de 1855, tentou convencer seus pares de que o entendimento da Comissão Especial de conferir à transcrição prova plena de domínio era mais "conducente e convinhavel" do que aquele expresso por NABUCO, tendo em vista que o intuito da lei era o de baratear capitais e estabelecer o crédito territorial. O deputado reconhecia que tal medida sofreria dificuldades para ser implantada, já que nem todas as propriedades imóveis no Brasil estavam livres de embaraços e que havia muitas questões pendentes a respeito delas. No entanto, não acreditava que isso fosse motivo suficiente para afastar a força probante da transcrição, afinal era preciso vencer as dificuldades e não simplesmente recuar. ${ }^{172}$

\footnotetext{
${ }^{171}$ No parecer apresentado na sessão de 14 de agosto de 1854 pela Comissão Especial eleita pela Câmara dos Deputados para examinar o projeto de reforma da legislação hipotecária apresentado por Nabuco de Araújo, fica claro seu posicionamento a favor da força probante da transcrição "Aqui desejaria a commissão dar ás transcripções valor maior do que lhe dá o projecto: a transcripção deve importar a prova da propriedade, e não uma simples presumpção; logo que ella é recommendada e obrigatoria, parece de logica rigorosa, e ao mesmo tempo conveniente para afastar meios de fraude, que sempre a má fé procura, e consegue descobrir, que se lhe dê a importancia do verdadeiro titulo". Brasil. Annaes do Parlamento Brazileiro. Câmara dos Deputados. Sessão de 1854. Tomo Quarto. Rio de Janeiro: Typographia de - Hyppolito José Pinto, 1876. p. 159.

${ }^{172}$ Interessante a percepção que o deputado pelo Rio de Janeiro tinha acerca da questão da terra no país. Na mesma sessão, no final de sua explanação, afirmou: "Disse, Sr. Presidente, que ha no fôro pendentes muitos pleitos ácerca da propriedade ou dominio de bens de raiz; mas cumpre confessar que a maxima parte de taes bens acha-se desembaraçada, e sem contestação os respectivos títulos; os pleitos pois que põem em duvida a validade dos títulos formão a excepção que firma a regra em contrario - a validade da máxima parte delles: ora, a legislação deve antes seguir, acompanhar, conformar-se com a regra do que com a excepção; tanto mais porque a legislação que se pretender estabelecer pelo projecto não é de natureza transitória, mas duradoura e permanente". Brasil: Annaes do Parlamento Brazileiro. Câmara dos Srs. Deputados. Sessão de 1855. Tomo Segundo. Rio de Janeiro: Typographia de Hyppolito José Pinto \& C. a, 1875. p. 256.
} 
Respondendo à Comissão e especialmente ao deputado BARreto Pedroso, na sessão de 20 de agosto de 1856, NABUCO afirmou que não havia dúvida de que tornar a transcrição prova plena de domínio seria mais eficaz para o crédito garantido por um imóvel, uma vez que daria certeza e confiança aos credores, no entanto, perguntava aos deputados se seria possível tal previsão. ${ }^{173}$

Para o Conselheiro NABUCO, permitir que a transcrição declarasse senhor da coisa aquele que a transcrevesse, constituiria uma inversão da organização judiciária, o que a Constituição Imperial não permitia. Afinal, a transcrição tiraria ou concederia direito de propriedade sem que o Judiciário exercesse sua jurisdição. O autor também perguntava aos deputados se a transcrição seria feita unicamente com base na declaração do adquirente, o que a seu ver era um absurdo. Para que ela valesse como prova plena de propriedade, seria preciso um processo em que fosse feita a citação das partes contratantes e dos interessados, a exibição dos títulos de domínio, a discussão das provas e só então se obteria a decisão. Assim, cada transcrição seria uma demanda e toda propriedade ficaria em litígio. NABUCO completava suas objeções afirmando que, se considerado o estado em que a propriedade se encontrava, fazer com que a transcrição valesse como prova plena de domínio, seria uma revolução. ${ }^{174}$

Ao elaborar o projeto de reforma da legislação hipotecária, NABUCO levou em consideração o estado em que a propriedade imóvel encontrava-se, e previu uma transcrição que servisse apenas para atestar o fato da alienação. Para o Conselheiro e na época Ministro da Justiça, a transcrição com essa característica não era inútil, continha o suficiente para o sistema hipotecário que se tentava organizar. ${ }^{175}$

\footnotetext{
173 Brasil. Annaes do Parlamento Brazileiro. Câmara dos Deputados. Sessão de 1856. Tomo Quarto. Rio de Janeiro: Typographia de - Hyppolito José Pinto \& C. ${ }^{\mathrm{a}}$, 1875. p. 232.

174 Brasil. Annaes do Parlamento Brazileiro. Câmara dos Deputados. Sessão de 1856. Tomo Quarto. Rio de Janeiro: Typographia de - Hyppolito José Pinto \& C., 1875. p. 232.

${ }^{175}$ Nabuco de ARAúso deixava claro seu entendimento ao proferir as seguintes palavras: "O registro como o projecto o estabelece não é inútil, porque elle comprehende todos os factos que convém saber, e que importão ao emprestador: - Houve alienação? ha outras hypothecas? ha ônus reaes sobre o immovel? - Não comprehende porém, e não póde comprehender, as questões de direitos, como: - É legítimo o proprietário, o herdeiro? é valido o contracto? é capaz o contractante? - Creio pois, senhores, que o registro, respondendo somente, ás questões de facto, é satisfactorio; que respondendo ás questões de direito, seria impraticável, não satisfaria os escrúpulos do emprestador.” Brasil. Annaes do Parlamento Brazileiro. Câmara dos Deputados. Sessão de 1856. Tomo Quarto. Rio de Janeiro: Typographia de - Hyppolito José Pinto \& C. a 1875. p. 232.
} 
O mesmo achava TeiXeIRA de Freitas que, em 1857, confirmou a opinião de Nabuco de Araújo por meio da "Consolidação das Leis Civis". O autor acreditava que o sistema da transcrição, como ato concomitante à convenção e responsável em operar a transferência de domínio e atribuir direitos reais, era interessante na medida em que ao dar publicidade às alienações e hipotecas, evitava estelionatos e outras fraudes. Ademais, a transcrição distinguia direitos reais e pessoais e preenchia completamente os fins da tradição.Assim, era importante mesmo que não purificasse a propriedade. ${ }^{176}$

Dessa forma, com clareza percebe-se que havia motivos suficientes para não proporcionar à transcrição força probante, por mais que isso levasse à manutenção da insegurança no crédito garantido por um bem imóvel.

Segundo Didimo Agapito da Veiga, como reação a esse regime hipotecário incompleto de 1864, os estabelecimentos de crédito real passaram a exigir como condição dos contratos hipotecários, a especialização da propriedade ${ }^{177}$ por meio da demarcação e medição dos imóveis rurais oferecidos em hipoteca. ${ }^{178}$

O receio dos estabelecimentos de crédito derivava em grande parte dos efeitos de uma hipoteca realizada sobre imóvel a non domino. Como o adquirente obtinha o imóvel de quem não era dono, estava sujeito a reivindicação e como a hipoteca recaía sobre bem que não era do devedor, era considerada nula. A hipoteca só passava a ter validade se o devedor adquirisse novamente o mesmo bem, mas desta vez do real proprietário, caso em que o domínio superveniente validava o direito de garantia.

VeIGA, citando acórdão de 1855 (que segundo o autor é seguido por grande número de decisões dos tribunais), afirmava que a jurisprudência da época entendia que como a transcrição não induzia prova de domínio, este só poderia ser debatido entre as partes contratantes, logo, independentemente da maneira como o conflito fosse decidido, não poderia atingir terceiros para os quais vigorava os efeitos legais da transcrição. Com esse

\footnotetext{
${ }^{176}$ Consolidação das Leis Civis. Rio de Janeiro: Typographia Universal de Laemmert, 1865. p. CLXXVI.

${ }^{177}$ A legislação apenas irá prever a especialização do imóvel hipotecado a partir do decreto n.169-A de 1890 .

${ }^{178}$ Direito Hypothecario commentario ao decreto $169-A$ de 19 de janeiro de 1890. Rio de Janeiro: Laemmert \& C. Editores, 1899. p. 303.
} 
entendimento, o credor estava protegido da reivindicação do imóvel hipotecado, já que sua garantia sempre continuava tendo validade. ${ }^{179}$

Com esta interpretação jurisprudencial, a Lei Hipotecária de 1864 acabou por garantir a segurança do crédito como era seu principal intuito sem, contudo apelar para a força probante da transcrição.

Para não depender da decisão do tribunal, o certo seria que a Lei fornecesse assento seguro ao registro hipotecário, atendendo ao interesse dos estabelecimentos de crédito. Segundo VeIga, isso só seria possível com um sistema registral em que a transcrição descrevesse o verdadeiro estado do imóvel em relação a seu proprietário e prevalecesse com este efeito não somente quanto a terceiros, mas também entre as partes contratantes. ${ }^{180}$

Era também o que acreditava TeIXEIRA DE FreITAS, para quem a confiança do credor somente não seria ilusória, ou seja, ele poderia acreditar que caso a dívida não fosse paga, o valor do imóvel a compensaria, no caso em que o bem pertencesse ao devedor e estivesse disponível. Além dessa condição, o jurista enumerava mais uma, que consistia em garantir ao credor que no momento do pagamento, o valor do imóvel não seria diminuído por encargos que eram totalmente desconhecidos no momento do contrato e imprevistos. ${ }^{181}$

Esse entendimento de TeIXeIRA DE Freitas aparece em sua obra "Consolidação das Leis Civis". Apesar de ter sido concluída em 1857, o trabalho já incluía em seus dispositivos artigos referentes ao projeto da lei de 1864, que o autor denominava de "novíssima Lei Hypothecaria". ${ }^{182}$

\footnotetext{
${ }^{179}$ Ibidem., p. 305 e 306.

${ }^{180}$ Direito Hypothecario commentario ao decreto 169-A de 19 de janeiro de 1890. Rio de Janeiro: Laemmert \& C. Editores, 1899. p. 254.

${ }^{181}$ Consolidação das Leis Civis. Rio de Janeiro: Typographia Universal de Laemmert, 1865. p. CXLV. Perceba que são as mesmas exigências apresentadas por ZaCARIAS DE GóEs na sessão do Senado de $1^{\circ}$ de março de 1864. Brasil. Annaes do Senado do Império do Brasil, $1^{\text {a }}$ sessão de 1864, vol. III. Rio de Janeiro: Typ. do Correio Mercantil de M. Barreto, Mendes Campos, e Comp.,1864. p. 3.

182 A Consolidação das Leis Civis em seu Livro II “Dos Direitos Reais", Título I "Do Domínio" previa:

“Art. 906. As coisas que tem já proprietário adquirem-se pela transferência legítima de um proprietário a outro. (Ordenações Livro 4, Título 58, $§ 3^{\circ}$ )

Art. 907. O título justo para essas aquisições deriva do contrato (1) das disposições de última vontade (2), das decisões judiciárias (3), e da determinação da Lei (4).

(1) ... Devem ser transcriptos no registro geral (Art. $7^{\circ}$ da novíssima Lei Hypothecaria) todos os títulos entre vivos translativos de imóveis suscetíveis de hypoteca, e os constitutivos de direitos reaes sobre os mesmos imóveis. (...) A transmissão entre vivos (Art. $8^{\circ}$ da cit. Lei), por título oneroso ou gratuito, dos bens suscetíveis de
} 
Apesar das discussões ao redor dos efeitos da transcrição, pode-se afirmar que a Lei de Hipotecária de 1864 representou um avanço na matéria de hipotecas, ao prever a transcrição das modificações jurídico-reais. ${ }^{183}$ As deficiências do regulamento da Lei Orçamentária de 1843 foram parcialmente solucionadas, já que pela primeira vez o legislador brasileiro percebeu que não havia como garantir a segurança jurídica do crédito, sem que estivesse bem definido o proprietário do bem. Para isso, transcrever as transmissões da propriedade imóvel surgiu como solução, apesar da dificuldade de se chegar ao real proprietário por meio da aquisição derivada. Afinal, já se sabia que a simples transcrição da última aquisição do imóvel não seria suficiente para garantir segurança ao crédito. Ou se fornecia à transcrição a possibilidade de sanar todos os vícios do domínio sobre o imóvel (o que era inviável diante da situação em que as terras se encontravam), ou protegia-se o terceiro de boa-fé que contratasse com o adquirente a non domino. Como já visto, a jurisprudência brasileira optou pela segunda solução.

Entretanto, exposto o problema quanto à definição do verdadeiro titular, resta saber como o problema da determinação do imóvel, seus limites e medidas era solucionado. Como já foi dito, os estabelecimentos de crédito já haviam expressado a importância de se indicar com precisão as características do bem imóvel ao exigir para a instituição da hipoteca a especialidade do bem. Se a Lei de Terras tivesse surtido os efeitos esperados, esse requisito já

hypoteca, assim como a instituição de ônus reaes não operam seus efeitos a respeito de terceiro, senão pela transcripção e desde a data della. (...) A transcripção (Art. $8^{\circ} \S 4^{\circ}$ da cit. Lei) não induz a prova do domminio, que fica salvo a quem fôr. (...)

(2) Cit. Ord.Liv. $4^{\circ}$ T. $58 \S 4^{\circ}$ - titulo justo, assim como testamento, codicilo.

(3) Ord. L.1 T.78 $\S 8^{\circ}$ - posses que foram tomadas por rigor de sentenças, ou mandados de juizes. - Ord.L. $1^{\circ}$ T.79 $\S 14$.

(4) Alv. De 9 de novembro de 1754, e Ass. De 16 de fevereiro de 1786.

Art. 908. Para aquisicção do domminio não basta simplesmente o título, mas deve aceder a tradição; e sem esta só se tem direito à acções pessoaes (art. 534)".

"Art. 534. Vendida a mesma cousa a duas diferentes pessoas, prefere o comprador a quem primeiro se fez a entrega, se a esta acedeu o pagamento do preço, ou o vendedor se deu por pago (3).

(3) ... Estamos hoje quanto a transmissão de immoveis por ato entre vivos no caso desses paises onde os registros dos títulos translativos da propriedade imóvel é a sua tradição legal".

No entanto, na introdução do trabalho, Teixeira de Freitas afirma "Com a inserção da clausula - constituti - em todas as nossas escripturas póde-se dizer que está sem applicação quanto aos immóveis a regra do Art. 534 Consolid.; póde-se dizer que temos o systema espiritualista do Cod. Civil da França".

Consolidação das Leis Civis. Rio de Janeiro. Typographia Universal de Laemmert, 1865. p. 431, 433 e nota de rodapé p. CLXXVI e CLXXVII.

${ }^{183}$ Nesse sentido Perdigão Malheiros, para quem "É possível, é provável mesmo que não seja o mais perfeito o que fez. Mas a lei e os regulamentos já foram um grande melhoramento, sobretudo para o fim especial que se teve em mira". Repertório ou Índice Alphabetico da Reforma Hypothecaria e sobre sociedades de credito real. Rio de Janeiro: Typographia Nacional, 1865. p. VII. 
teria sido preenchido com a existência de um registro geral de terras; porém, como isso não ocorreu, as especificações quanto à dimensão do imóvel e seus limites continuaram desconhecidas. A Lei Hipotecária tentou conhecer a propriedade, no entanto foi falha por não atender ao princípio da especialidade, nem permitir a inscrição de hipotecas gerais. De fato, por mais que houvesse uma descrição do imóvel e indicação dos contratantes, nada se compara ao que hoje se denomina de princípio da especialidade. ${ }^{184}$

A Lei não atendia a especialidade objetiva, já que não exigia que se constassem nos livros todas as características físicas do bem (indicadas por um agrimensor) nem sua localização. Essa falta só foi corrigida com o decreto n. 3.453 de 5 de outubro de 1865 que regulou a Lei Hipotecária.

Com este novo decreto, para se transcrever o título, era necessário individualizar o imóvel e o negócio, determinando as características de cada um deles, o que dificultava a ocorrência de fraudes. Segundo seu artigo 269, o oficial deveria escrever no "livro das transcrições": a) o número de ordem (ou seja, aquele que ele recebia assim que ingressava no estabelecimento registrário), b) a data, c) a freguesia em que o imóvel era situado, d) a denominação do imóvel, se fosse rural, e rua e número se fosse urbano, e) confrontações e característicos do imóvel, f) nome e domicílio do adquirente, g) nome e domicílio do transmitente, h) título da transmissão (ou seja, se era venda, permuta, ou outro), i) forma do título e tabelião que o fez, j) valor do contrato, k) condições do contrato, 1) averbações.

Como fica claro, não houve a preocupação em prever-se o princípio da especialidade subjetiva, que esquecido pelo legislador de 1864 assim se manteve pelo de 1865 . O princípio da especialidade subjetiva consiste na identificação e qualificação dos sujeitos da relação jurídica, descrevendo o máximo possível o indivíduo, para que não haja qualquer confusão. A lei não exigia essa especificação, bastando unicamente o nome dos contrates, o que facilitava a ocorrência de homonímias.

\footnotetext{
${ }^{184}$ Pelo princípio da especialidade registrária, o imóvel e os sujeitos envolvidos no ato objeto de registro devem estar muito bem definidos. O que significa dizer, que todas as informações necessárias para a identificação do imóvel devem ser conhecidas como, por exemplo, suas medidas, área, confrontações e localização (especialidade objetiva). Da mesma maneira, os sujeitos envolvidos devem ser bem determinados, constando no assento registral suas qualificações, ou seja, nome, domicílio, nacionalidade, número no registro geral, número no cadastro de pessoas físicas, profissão, estado civil, se pessoa física; e nome, domicílio, nacionalidade, sede social e número de inscrição no Cadastro Geral de contribuintes se pessoa jurídica (especialidade subjetiva).
} 
Outra lacuna da Lei Hipotecária de 1864 consistiu no não atendimento ao princípio da publicidade, uma vez que ela não previa o registro das transmissões causa mortis e das hipotecas legais. Mais uma vez o decreto n. 3.453 de 1865 solucionou uma das omissões ao prever a obrigatoriedade da inscrição de todas as hipotecas legais. Contudo, a ausência de previsão do registro da transmissão causa mortis permaneceu, ampliando a não exigência também aos atos judiciais (art. 260).

A não previsão pela lei de 1864 da transcrição das transmissões causa mortis foi criticada antes mesmo de sua promulgação, quando o projeto ainda era debatido na Câmara dos Deputados. Em sessão de 26 de julho de 1855, o deputado NunEs GonçALves chegou a afirmar que tal medida nada mais era do que uma reprodução do que ocorria na França, porém sem que se atentasse para as razões especiais presentes naquele país. Segundo o deputado, na França, a propriedade estabelecia-se pelo simples fato da filiação, não sendo necessário nenhum ato posterior, para que o herdeiro alienasse o bem após a morte do de cujos. Já no Brasil, a situação era diferente, uma vez que o herdeiro antes da partilha apenas gozava da posse civil sobre o imóvel, não podendo dele dispor. Assim, entre a morte do de cujos e a partilha, qualquer interessado podia anular as medidas que fossem tomadas para a sucessão dos bens. NunEs Gonçalves concluía que não havia razão para dispensar as transmissões causa mortis da transcrição, se estas estavam sujeitas às "mesmas dívidas e contestações" que a transmissão inter vivos. ${ }^{185}$

VeIGA apresentava outra razão para a necessidade de também se transcrever as transferências causa mortis. Segundo o autor, o fato da lei não exigir a transcrição nesses casos impedia a formação no registro de uma cadeia com todos os proprietários sucessivos do bem. Afinal, deixava-se em descoberto a transferência mais usual, ou seja, aquela ocorrida com a morte do proprietário, o que proporcionava uma lacuna na publicidade dos atos que envolviam o imóvel. ${ }^{186}$

Teixeira de Freitas discordava dessas colocações. Para o autor, a publicidade que se dava às transmissões inter vivos não era necessária nas causa mortis, já que nestas o

\footnotetext{
${ }^{185}$ Brasil. Annaes do Parlamento Brazileiro. Câmara dos Srs. Deputados. Sessão de 1855. Tomo Segundo. Rio de Janeiro: Typographia de - Hyppolito José Pinto \& C. ${ }^{\text {a }}$ 1875. p. 243.

${ }^{186}$ Direito Hypothecario commentario ao decreto 169-A de 19 de janeiro de 1890. Rio de Janeiro: Laemmert \& C. Editores, 1899. p. 294.
} 
proprietário não podia realizar mais de uma alienação do mesmo imóvel, incorrendo em fraude. A transmissão decorria de um único fato, o falecimento. Como para TeIXEIRA DE FREITAS, a publicidade das transmissões de bens tinha como intuito unicamente proporcionar maior segurança à mutuante e adquirente no momento de realizar negócios envolvendo imóveis perante alienador e devedor hipotecário, ela se mostrava desnecessária em transmissões causa mortis, uma vez que o de cujos não poderia fraudar o direito do herdeiro. ${ }^{187}$

LAFAYETTE também entendia que não havia motivo para se exigir a transcrição da transferência causa mortis. Para o autor, a sucessão legítima e a testamentária eram atos que por si só apresentavam publicidade, não precisando do instituto da transcrição para esse fim. A transcrição também não era necessária para a transmissão do imóvel, uma vez que a sucessão transferia o domínio desde sua abertura, não existindo tradição. Assim, exigir a transcrição para a transferência do imóvel significaria afastar um princípio já consolidado no ordenamento jurídico, ou seja, que os bens passavam do de cujos para seus herdeiros no momento de sua morte. $^{188}$

Para Lacerda de Almeida, o fato de haver a transmissão imediata da posse dos bens hereditários com a morte de seu proprietário não impedia que a transferência fosse transcrita para dar publicidade a terceiros e mesmo as próprias partes. ${ }^{189}$

Quanto à previsão expressa de que atos judiciários não estariam sujeitos à transcrição, LAFAYETTE entendia que o decreto havia contrariado a razão da Lei Hipotecária de 1864 ao criar tal dispositivo. Afinal, a norma regulamentada previa a transcrição de todos os atos inter vivos, e a arrematação e a adjudicação eram atos inter vivos em que o juiz representava o alienante. Além de o decreto contrariar a lei que tinha como objetivo regular, a ausência de transcrição das cartas de arrematação e adjudicação permitia fraudes que o registro tinha como escopo evitar. Afinal, sem a transcrição, o executado poderia vender imóvel já arrematado ou adjudicado a terceiro de boa-fé. ${ }^{190}$

\footnotetext{
${ }^{187}$ Consolidação das Leis Civis. Rio de Janeiro: Typographia Universal de Laemmert, 1865. p. CLXXVI.

${ }^{188}$ Direito das Cousas. Rio de Janeiro: Jacintho Ribeiro dos Santos, [188?]. p. 122 e 123/vol.1.

${ }^{189}$ Direito das Cousas. Rio de Janeiro: Jacintho Ribeiro dos Santos, 1908. p. 187.

${ }^{190}$ Direito das Cousas. Rio de Janeiro: Jacintho Ribeiro dos Santos, [188?]. p. 123/vol.1.
} 
Para os legisladores, o ato judiciário e os causa mortis não precisavam de transcrição, porque tinham notoriedade suficiente para evitar a má-fé. LAFAYETTE discordava no relativo aos atos judiciários, afirmando que assim como a escritura pública, sua publicidade não era suficiente para evitar fraudes. Se a lei achava que era insuficiente a publicidade gerada pelo livro de notas, o mesmo deveria achar dos cartórios judiciais. ${ }^{191}$

Esse também era o pensamento de LACERDA DE Almeida, para quem o fato das aquisições ocorrerem em hasta pública, à luz do dia e com toda publicidade, não era justificativa para a não realização da transcrição. Afinal, não era esta publicidade momentânea que buscava a lei que instituiu o registro, nem aquela desejada para se proporcionar segurança ao crédito garantido por um bem imóvel. Só era possível dar publicidade a este crédito real, quando as informações pertinentes ao imóvel fossem de fácil acesso a qualquer interessado. Ademais, em alguns atos judiciais, não havia nem mesmo a publicidade da hasta pública, sendo a publicidade da sentença um mito. Sendo assim, o autor concluía que todos os atos que afetavam a propriedade imóvel deveriam ser registrados. ${ }^{192}$

Com base nas considerações de Lafayette e Lacerda de Almeida, percebe-se que o decreto n. 3.453 de 1865, ao invés de sanar as insuficiências da Lei de 1864, trouxe maiores lacunas ao registro imobiliário no que se referia à transcrição. Da mesma maneira, o decreto tornou claro o entendimento de que o "título" referido no artigo $7^{\circ}$ da Lei Hipotecária englobava apenas as escrituras públicas e inscritos particulares de transferências imobiliárias.

A inovação desse decreto hipotecário (n. 3.453 de 1865) foi a de pela primeira vez estabelecer a estrutura e funcionamento do registro imobiliário, que denominado de registro geral, substituiu o antigo registro de hipotecas (art. $2^{\circ}$ ) no ordenamento jurídico brasileiro. Até então, o decreto n. 482 de 1846, tinha disciplinado sobre esses aspectos, porém somente no que se referia à hipoteca e não acerca da transferência de imóveis. A nova legislação dispôs sobre: a instalação de registros gerais (art. $1^{\circ}$ ao $6^{\circ}$ ), oficiais (art. $7^{\circ}$ a 12), livros (art. 13 a 42), ${ }^{193}$ ordem de serviço e processo de registro (art. 43 a 79) e a função de publicidade (art. 80 a 89). Ainda, tratou sobre os emolumentos devidos ao oficial (art. 90 a 97), as

${ }^{191}$ Direito das Cousas. Rio de Janeiro: Jacintho Ribeiro dos Santos, [188?]. p. 123/vol.1.

${ }^{192}$ Direito das Cousas. Rio de Janeiro: Jacintho Ribeiro dos Santos, 1908. p. 187 e 188.

${ }^{193}$ O livro número 4 era destinado a "Transcrição das transmissões". 
responsabilidades deste (art. 98 a 101) e sobre o cancelamento do registro (art. 102 a 109). No título II e IV dedicou-se, respectivamente, às hipotecas (art. 110 a 225) e às ações hipotecárias (art. 282 a 315) e no título III à transcrição (art. 256 a 281).

Desse modo, não há como negar que a Lei Hipotecária de 1864 e seu regulamento trouxeram boas inovações, tornando-se marcos legislativos na matéria referente à transcrição (tanto por tê-la previsto, quanto por ter fornecido estrutura para sua realização).

Em 15 de novembro de 1889, com a proclamação da República, esperavam-se algumas modificações no ordenamento jurídico; todavia, durante certo tempo elas não ocorreram. Em 24 de fevereiro de 1891, a primeira Constituição Republicana declarou em vigor as leis do antigo regime, enquanto não fossem revogadas e desde que não contrariassem o novo sistema de governo e os princípios por ele consagrados, mantendo-se a estrutura legislativa imobiliária do passado.

Na República, a primeira norma referente à transmissão de bens e constituição de ônus reais foi o decreto n. 169-A de 19 de janeiro de 1890 que tratou sobre a matéria até o advento do Código Civil. Ele alterou a Lei Hipotecária de 1864 em vários pontos, mas manteve tanto a exigência da transcrição para a transferência do domínio e constituição de ônus reais, quanto o registro imobiliário sem valor probante. Na verdade, houve no relativo a esses assuntos uma mera cópia dos artigos da lei n. 1.237 de 1864, com a diferença que no relativo à transcrição, ampliou-se o rol dos imóveis suscetíveis à hipoteca, incluindo engenhos centrais, fábricas, usinas, oficinas e estradas de ferro (art. $2^{\circ}, \S 1^{\circ}$ ) e excluiu-se o dispositivo referente à hipoteca sobre escravo $\left(\operatorname{art} .2^{\circ}, \S 1^{\circ}\right)$.

O decreto n. 169-A de 1890 ainda consagrou em seus artigo $4^{\circ}, \S 1^{\circ}$ e $5^{\circ}$ o princípio da especialidade para todas as hipotecas, ao exigir sua determinação individual, excluindo as previsões das hipotecas gerais ${ }^{194}$. No entanto, o decreto não regulava a maneira

\footnotetext{
194 "Desappareceram do nosso systema de direito as hypothecas geraes; foi sem dúvida, um grande passo em bem do fim economico que se propõe alcançar um bom regimem hypothecario, elevando o crédito territorial, pela certeza da valorização da propriedade immovel, valorização intimamente ligada á publicidade do seu estado, em referência aos onus reaes, que a possam gravar, e especialmente aos encargos hypothecarios" VeIGA, Didimo Agapito da. Direito Hypothecario commentario ao decreto 169-A de 19 de janeiro de 1890. Rio de Janeiro: Laemmert \& C. Editores, 1899. p. 68.
} 
como essa especialização deveria ser feita, nem que ela também estaria presente no ato de transcrever a transmissão dos bens imóveis.

A exigência de se definir o bem imóvel no ato de transcrição só surgiu alguns meses mais tarde com o decreto n. 370 de 2 de maio de 1890, que regulava a execução da norma n. 169-A do mesmo ano.

A partir de então, a transcrição da transmissão dos imóveis deveria conter número de ordem, data, freguesia onde o imóvel era situado, denominação do imóvel, se fosse rural, e menção da rua e número se fosse urbano, confrontações e característicos do bem, nome e domicílio do adquirente e do transmitente, título de transmissão, forma do título e nome do tabelião que o havia elaborado, valor e condições do contrato, averbações (art. 245 e parágrafos). Apesar de incipiente, a medida não poderia ser ignorada, principalmente no que diz respeito à especialidade subjetiva.

O decreto n. 370 também dispunha sobre os Registros Gerais, determinando sua inauguração em novas comarcas (art. $1^{\circ}$ ), sobre os oficiais do Registro (art. $6^{\circ}$ ao $10^{\circ}$ ), enumerava os Livros exigidos, separando o livro 3 para transcrever a transmissão dos imóveis (art. 25), definia a ordem do serviço e o processo do registro (art. 40 a 76), previa a publicidade do registro (art. 77 a 86), os emolumentos, a responsabilidade do oficial (art. 95 a 98) e as possibilidades de cancelamento do registro (art. 99 a 106), separava um título à transcrição, entre outros dispositivos.

Além da previsão da especialidade, ${ }^{195} \mathrm{o}$ decreto não trouxe grandes modificações ao ordenamento jurídico brasileiro, sendo no que diz respeito ao funcionamento do registro geral, mera repetição do regulamento hipotecário de 1865. Ademais, acompanhando o art. 257 do decreto n. 3.453, mais uma vez selou a interpretação do art. $8^{\circ}$ da lei n. 1.237 de 1864 , prevendo:

“Art. 234. Até a transcripção, os referidos actos são simples contractos, que só obrigam as partes contratantes."

195 Outra inovação do decreto consistiu na inclusão entre os títulos sujeitos ao registro dos atos autênticos de países estrangeiros legalizados pelos cônsules brasileiros e traduzidos na língua nacional (art. 74). Assim, alargava-se o conceito de "título", permitindo, por exemplo, que contrato de aquisição de imóvel localizado no Brasil pudesse ser lavrado perante tabelião estrangeiro. 
O decreto reproduziu também a orientação anterior, ao negar em absoluto à transcrição poder para provar os direitos que publicava (art. 235). Ademais, continuou não exigindo a transcrição de transmissões causa mortis e a dos atos judiciários, apesar das críticas da doutrina, principalmente quanto a essa última omissão. (art. 237).

Depois da análise desse conjunto de leis e decretos que se referiam à transcrição das transferências de domínio (pelo menos em alguns dispositivos), pode-se afirmar que apesar de todas as inovações apresentadas e de um sistema registrário mais completo, embora ainda lacunoso, a irregularidade das terras continuava.

\subsection{Registro Torrens: decreto N. 451-B de 1890 .}

A situação das terras brasileiras continuava desordenada. Até então, em nenhum momento na história legislativa do país, o governo havia se preocupado em regularizá-la. Sempre os interesses eram outros. Na Lei de Terras, o objetivo era distinguir as terras públicas das particulares, a fim de que as primeiras pudessem ser concedidas aos colonos estrangeiros. Com a publicação da Lei Orçamentária de 1843 e da Lei Hipotecária de 1864 o intuito era assegurar o crédito garantido por um bem imóvel. Em todos os casos, para se atingir as finalidades das leis, foi necessário mexer na propriedade imóvel, seja definindo suas medidas e limites, seja transcrevendo títulos de hipotecas ou de transferências de domínio.

Mas como as legislações não visaram diretamente a regularização dos imóveis, foram publicadas com inúmeras lacunas e em alguns casos não tiveram qualquer eficácia, o estado das terras mantinha-se caótico. Imprecisão de medidas e limites, incerteza quanto aos reais proprietários, muitos possuidores, fraude em títulos, indefinição das terras públicas e devolutas. Assim, o quadro de insegurança jurídica persistia, até mesmo no que era relativo ao crédito.

Diante desse panorama, os legisladores brasileiros resolveram pôr em ordem de vez a questão da terra, promulgando dois decretos em 1890, o n. 451-B, de 31 de maio, e o 
decreto n. 955-A, de 5 de novembro, que estabeleciam o registro e a transmissão de imóveis pelo sistema Torrens.

Afrânio de Carvalho afirmava que a adoção desse sistema no Brasil surgiu da necessidade emergencial de se adotar disposições registrárias, que acabassem com a falibilidade e incerteza da propriedade territorial no país. ${ }^{196}$

$\mathrm{Na}$ Exposição de Motivos que acompanhou o projeto que deu origem ao decreto n. 451-B de 1890, apresentado à Câmara dos deputados em 31 de maio de 1890, seus idealizadores Ruy Barbosa, Manuel F. de Campos Salles e Francisco Glycerio afirmavam que a instituição consagrada no projeto tinha como objetivo "estabelecer um systema efficaz de publicidade immobiliaria, e commercialisar a circulação dos titulos relativos ao dominio sobre a terra" ${ }^{197}$. Assim, o intuito não era só tornar pública a situação jurídica do imóvel, mas também possibilitar a mobilização do solo, por meio da transferência rápida e simples de seu título. $^{198}$

Américo Lopes e Cícero Lopes analisando a exposição de motivos em 1925 entenderam que o sistema Torrens foi aplicado para garantir os direitos do proprietário, ao eliminar qualquer dúvida quanto a esse direito e estabelecê-lo de modo irrevogável. Dessa ${ }^{196}$ Registro de Imóveis. $3^{\mathrm{a}}$ ed., Rio de Janeiro: Forense, 1982. p. 471.

197 A Exposição de Motivos esta transcrita In: Lopes, Américo; Lopes, Cícero. Commentarios, Notas e Formulários sobre o Registro Torrens. Rio de Janeiro: Jacintho Ribeiro dos Santos, 1925. p. 15.

198 Ainda na Exposição de Motivos, os autores além de recomendarem veementemente a adoção do nosso sistema no Brasil, listam todos as suas características. Dizem: “... não hesitamos em aconselhar, vos a transplantação desta reforma para o nosso torrão pátrio onde encontrará certamente as condições mais favoraveis de acclimatação, logo que os interessados lhe comprehendam a influencia bemfazeja.

Reduzindo-o aos seus traços capitaes, o regimen proposto assignala-se caracteristicamente por estes predicados:

$1^{\circ}$ Faculdade aos proprietarios de acceitarem-no, ou permanecerem no direito commum;

$2^{\circ}$ Registro de todos os direitos que gravarem o immovel, para a constituição delles entre as partes e a sua acção contra terceiros;

$3^{\circ}$ Garantia do Estado aos proprietarios inscritos e, em conseqüência, responsabilidade pecuniaria do Thesouro para com os prejudicados por erros na matricula, ou na entrega dos títulos;

$4^{\circ}$ Publicidade real, e não pessoal, isto é, instituição de um grande livro das terras, onde cada propriedade, em vez de cada proprietário, tenha aberta a sua conta;

$5^{\circ}$ Entrega a cada proprietário de um certificado com o valor do titulo, renovavel em cada transferencia de propriedade;

$6^{\circ}$ Facilidade aos proprietarios de constituírem emprestimo, mediante penhor do titulo, consignado em garantia ao mutuante;

$7^{\circ}$ Substituição da incerteza pela segurança, da obscuridade e do palavreado pela brevidade e pela clareza;

$8^{\circ}$ Reducção de avultados gastos a um desembolso mínimo, e abreviação de mezes a dias no tempo despendido;

$9^{\circ}$ Protecção ás transações sobre a propriedade territorial contra a generalidade das fraudes;

$10^{\circ}$ Restituição ao seu valor natural dos títulos de propriedade, depreciados pela interdependência das escripturas sucessivas de acquisição e transmissão”. Ibidem., p. 27 e 28. 
maneira, facilitava-se a realização de atos jurídicos envolvendo a propriedade imóvel, por meio de um título público. ${ }^{199}$

Já AfrÂNIO de CARvalho interpretava a previsão do sistema de forma mais crítica. Para o autor, o Governo brasileiro resolveu adotar o Registro Torrens, oferecendo-o facultativamente aos particulares, para afastar a tarefa reformadora do Registro Imobiliário comum que parecia ser difícil e demorada, porém cada vez mais necessária. A medida ainda trazia como vantagem, o fato dos dispositivos do novo registro já estarem reunidos em um texto legislativo estrangeiro, o que simplificaria o trabalho dos legisladores pátrios. ${ }^{200}$

Quanto ao caráter facultativo do registro, RuY BARBosa entendia que ele seria provisório, estaria presente quando da adoção do sistema, já que seu aspecto revolucionário exigia um período de adaptação no qual mostraria sua excelência, mas se tornaria coercitivo quando ficasse comprovada a superioridade dos resultados obtidos. ${ }^{201}$

O Registro Torrens foi criado por Sir Robert Richard Torrens, pai de um dos fundadores da colônia da Austrália do Sul. O sistema objetivava colocar uma certa ordem no estado de confusão em que os títulos de domínio, as transferências e aquisições estavam.

Torrens exerceu vários cargos públicos na Austrália, inclusive o de oficial de registro. Porém, foi como deputado pela Província de Adelaide que apresentou esse sistema de registro dando origem a lei "Real Propert Act" de 27 de janeiro de $1858 .{ }^{202}$

Para Jõ̃o Afonso Borges o sistema era excelente para os países novos, o que explicaria a sua rápida difusão nas diversas províncias da Austrália, em outras colônias

\footnotetext{
${ }^{199}$ Commentarios, Notas e Formulários sobre o Registro Torrens. Rio de Janeiro: Jacintho Ribeiro dos Santos, 1925. p. 12.

${ }^{200}$ Registro de Imóveis. $3^{\mathrm{a}}$ ed., Rio de Janeiro: Forense, 1982. p. 471 e 472.

201 Obras Completas de Rui Barbosa. Relatório do Ministro da Fazenda. Rio de Janeiro: Oficina Gráfica do Departamento de Imprensa Nacional, 1949, p. 302/vol.XVII, Tomo II.

${ }^{202}$ Esta é a data indicada na Exposição de Motivos elaborada por Ruy Barbosa, Manuel F. de Campos e Francisco Glycerio quando o projeto que deu origem ao decreto 451-B de 1890 foi apresentado a Câmara dos Deputados (Lopes, Améric; Lopes, Cícero. Commentarios, Notas e Formulários sobre o Registro Torrens. Rio de Janeiro: Jacintho Ribeiro dos Santos, 1925. p. 17). Esta mesma data é acompanhada por Lysippo (GARCiA, Lysippo. $O$ registro de Imóveis: a transcrição. Rio de Janeiro: Livraria Francisco Alves, 1922. p. 59/vol.1.) e Afrânio (CArvalho, Afrânio, Registro de Imóveis. $3^{\mathrm{a}}$ ed., Rio de Janeiro: Forense, 1982. p.472). Borges afirma que foi em 1861 (Borges, João Afonso. O Registro Torrens no Direito Brasileiro. São Paulo: Saraiva, 1960. p. 21).
} 
inglesas e também em colônias francesas. ${ }^{203}$ Não de forma diferente pensavam os legisladores brasileiros que instituíram o sistema registrário de origem australiana no ordenamento pátrio. ${ }^{204}$

O intuito era garantir a certeza da propriedade, proporcionando completa imunidade contra os ataques de quem quer que fosse. Para isso, o sistema Torrens fornecia presunção absoluta de domínio, sendo poucos os casos em que cabia ação de reivindicação contra o proprietário de imóvel submetido ao regime.

O decreto 451-B de 1890 determinava que apenas as terras públicas que fossem alienadas a partir de 31 de maio de 1890, e alguns terrenos e prédios da Capital Federal que o Governo julgasse conveniente, precisariam submeter-se ao registro Torrens. Assim, o sistema era facultativo para propriedades privadas.

Segundo Américo e Cícero Lopes, embora a lei fosse obrigatória para a alienação de terras públicas em todo o país, havia Estados que não a aplicavam, o que gerava a nulidade de todas as transferências de áreas devolutas realizadas pelo sistema comum. Por outro lado, em Minas Gerais e no Rio Grande do Sul, o registro Torrens foi utilizado não só para terras públicas, mas também para muitos terrenos particulares. ${ }^{205}$

O Registro Torrens é caracterizado pela existência de um livro talão denominado Matriz, no qual é inscrita cada propriedade com sua descrição perfeita, ou seja, constando suas

${ }^{203}$ O Registro Torrens no Direito Brasileiro. São Paulo: Saraiva, 1960. p. 21.

${ }^{204} \mathrm{~A}$ difusão do registro Torrens pelo mundo é demonstrada na Exposição de Motivos do projeto que deu origem ao decreto 451-B de 1890. No texto, citando a obra de Emile Worms "La proprièté consolidée", de 1888, os autores (Ruy Barbosa, Manuel F. de Campos e Francisco Glycerio) afirmavam que além de ser aplicado na Austrália, o sistema havia sido adotado pelas "ilhas de Fidji (1877), e o Estado de Lowa, na federação americana, e, por último, no Canadá, a província de Ontário, onde a legislatura o acolheu em 1885, mandando-o applicar á cidade de Toronto e ao condado de York. Ao justificar-se esta medida, na antiga dependencia britânica, declarou o primeiro ministro que o pensamento do gabinete era tornar a transferência da terra tão simples como a do papel bancário e o título do possuidor tão firme, tão isentos de riscos e tropeços quanto o do accionista de um estabelecimento de crédito ás acções de que é senhor. Outras províncias canadienses e outros Estados da União Anglo-saxonia promovem a sua adopção, de que tambem se cogita para a Índia, em Malaca, em Penang, em Strait Settemento. A regencia de Tunis, graças a iniciativa do governador Cambon, inspirada na propaganda activa de Ives Guyot, perfilhou, na lei de 12 de julho de 1885, a instituição australiana, de que já se aconselha tambem a applicação á Argélia”. Lopes, Américo; Lopes, Cícero. Commentarios, Notas e Formulários sobre o Registro Torrens. Rio de Janeiro: Jacintho Ribeiro dos Santos, 1925. p. 17. Este mesmo texto esta transcrito em Rui Barbosa. Obras Completas de Rui Barbosa. Relatório do Ministro da Fazenda. Rio de Janeiro: Oficina Gráfica do Departamento de Imprensa Nacional, 1949. p. 296 e 297/vol.XVIII, Tomo II.

${ }^{205}$ Commentarios, Notas e Formulários sobre o Registro Torrens. Rio de Janeiro: Jacintho Ribeiro dos Santos, 1925. p. 13. 
características, confrontações, medidas, benfeitorias existentes, classificação das terras e possíveis encargos que a vinculam. Quando o imóvel é inscrito no livro matriz, diz-se que ele foi matriculado e todas as suas particularidades passam a ser conhecidas.

Pelo decreto n. 451-B de 1890, o requerimento para o registro Torrens e, conseqüentemente, o pedido para a instituição da matrícula ${ }^{206}$ devia ser dirigido ao juiz pelo proprietário ou por quem tivesse mandato para o representar (art. $5^{\circ}$ ). Com o requerimento entregue ao oficial do Registro Geral de Hipotecas, apesar de endereçado ao juiz da comarca, iniciava-se o procedimento que daria origem a uma matrícula no livro matriz, no local em que seria a partir de então inscritas todas as alienações e constituições de direitos reais referentes ao imóvel.

O requerimento deveria ser instruído com os títulos de propriedade, com atos que a modificam ou limitem, memorial indicativo de todos os encargos, designando os nomes e residências dos interessados, ocupantes e confrontantes e, sendo imóvel rural, sua planta (art. $7^{\circ}$ ). Todos os documentos apresentados pelo interessado eram ordenados, autuados pelo oficial e enviados ao juiz competente.

Dessa forma, havia um processo administrativo passado diante do oficial do registro e um processo judicial, a cargo da Justiça Comum, para análise do título de domínio $^{207}$. Se os documentos mostrassem que o imóvel pertencia ao requerente, o juiz determinava a publicação do requerimento, uma vez no Diário Oficial e três vezes em jornais da localidade do bem, fixando um prazo não menor de 50 dias e não maior de quatro meses para a realização da matrícula caso não houvesse oposição (art. $8^{\circ}$ ). A pessoa que se julgasse com direito ao imóvel, apresentava oposição à inscrição perante o juiz responsável pelo Registro Torrens daquele imóvel (art. 46). Enquanto o litígio não fosse julgado, o registro

\footnotetext{
${ }^{206}$ AMÉrico e Cícero Lopes definem matrícula da seguinte forma "a matrícula é o termo final do processo da apuração dos títulos do requerente e á ella procede o official por ordem do juiz, escrevendo, com dizeres eguaes, nos talões do livro matriz, todos os esclarecimentos relativos ao immovel e aos encargos a que estiver sujeito". Commentarios, Notas e Formulários sobre o Registro Torrens. Rio de Janeiro: Jacintho Ribeiro dos Santos, 1925. p. 89.

${ }^{207}$ Nesse ponto o Registro Torrens adotado no Brasil diferenciava-se do australiano. Na Austrália o processo era todo administrativo. Segundo Afrânio de CARvalho, "Na adaptação ao nosso meio, a longa história dos títulos dominiais e extensão da superfície do País determinaram, pois, a preeminência da ação judicial e a descentralização do sistema, que não passou de um enxerto feito à ilharga do preexistente". Registro de Imóveis. $3^{\text {a }}$ ed., Rio de Janeiro: Forense, 1982. p.473.
} 
ficava suspenso (art. 47). Julgada a oposição improcedente, o oficial matriculava o imóvel no livro matriz, arquivando o processo e os documentos no Cartório de Registro Geral de Hipotecas. Sendo a oposição julgada procedente, a realização do registro Torrens era afastada.

A matrícula era feita por lançamento em duplicata, um exemplar ficava no livro matriz e o outro, que era chamado de "título" era entregue ao requerente (art. 10, $\left.\S 1^{\circ}\right)$. Esse último exemplar, que continha todas as características do imóvel e dos direitos reais que recaíam sobre ele, substituía todos os títulos anteriores ${ }^{208}$ Como conseqüência, o adquirente da propriedade não precisava preocupar-se com o seu passado, ou seja, com a possibilidade de defeitos em títulos que antecediam o seu direito, o que era a grande inovação desse modelo registrário e sua vantagem. ${ }^{209}$

Dessa maneira, quando ocorria venda ou alguma operação de crédito, a situação jurídica do imóvel podia ser verificada de modo simples e rápido. A análise recaía unicamente sobre o título (exemplar) dado ao último possuidor, sendo invalidados todos os anteriores. ${ }^{210}$ Como resultado disso, diminuíam-se as despesas com a transmissão e oneração do imóvel e estimula-se o crédito territorial.

A despreocupação com a situação jurídica do imóvel, existente após a realização do procedimento administrativo que dava origem ao Registro Torrens, derivava do fato de que este tornava o direito de propriedade indiscutível, absoluto. Caso alguém fosse privado do domínio ou da garantia hipotecária pela admissão parcial ou total de um imóvel no registro Torrens, o Estado responsabilizava-se, pagando uma indenização para o terceiro prejudicado.

\footnotetext{
${ }^{208}$ Segundo Sir R. ToRrens “Assim se supprimirão todas as dificuldades até hoje inevitáveis no investigar o título primitivo por entre a série numerosa de adquirentes, que cronològicamente se sucedem; e, em vez de folhear montanhas de papel, teremos de examinar apenas um documento simples, mas nem por isso menos valido e indiscutível, pois absolutamente não difere do título de concessão inicial" transcrito in Ru BARBosa. Obras Completas de Rui Barbosa. Relatório do Ministro da Fazenda. Rio de Janeiro: Oficina Gráfica do Departamento de Imprensa Nacional, 1949. p. 307 e 308/vol.XVIII, Tomo II.

${ }^{209}$ É o que também pensavam os autores do decreto n. 955-A de 1890, "A indestructibilidade do titulo constitue, manifestamente um dos caracteres inestimáveis do regimen australiano. Na incerteza sobre o direito de propriedade territorial está uma das influencias que profundamente a depreciam e um dos embaraços que organicamente se oppõem á sua mobilisação. A segurança estribada nesse título de domínio irrevogável habilita o proprietario a não recuar ante os maiores sacrifícios para a exploração da terra, e attrahe para ellas as ambições do capital, livre por esse meio dos riscos que ordinariamente o deteem ante a perspectiva de litigios embaraçosos e arruinadores, como os que flagelam a propriedade immovel". "Exposição de motivos" in Lopes, Américo; Lopes, Cícero. Commentarios, Notas e Formulários sobre o Registro Torrens. Rio de Janeiro: Jacintho Ribeiro dos Santos, 1925. p. 22 e 23.

${ }^{210}$ Ibidem., p. 24.
} 
Essa previsão decorria do fato de que não só no caso de fraudes, poderia ocorrer discordância entre a realidade e o registro. Afinal, por mais que durante o procedimento de análise dos títulos e caracterização da propriedade fossem utilizados de total imparcialidade e cuidados, erros poderiam acontecer, já que dependia-se de uma apreciação humana.

Prevista a indenização, nada mais coerente do que o decreto dispor sobre a maneira como seria obtido o recurso financeiro. $\mathrm{O}$ dinheiro provinha de um fundo de garantia, que era mantido pelo valor obtido com taxas pagas pela realização do registro e por multas, além dos juros obtidos com o passar do tempo.

Segundo Américo e Cícero Lopes, a existência do fundo e o pagamento de indenização no caso de privação de direitos reais dos legítimos titulares resultavam da garantia que o Estado oferecia ao proprietário matriculado, contra todas as contestações sobre o seu direito. ${ }^{211}$ Em outras palavras, ao adotar o sistema Torrens, o Estado garantia presunção absoluta de propriedade, indenizando o prejudicado caso incorresse em erro.

O sistema Torrens também possibilitava a mobilização do bem imóvel por meio de seu título, igualando-o nesse aspecto ao móvel. Tanto transferir a titularidade quanto gravar com ônus real tornavam-se atos de fácil execução, uma vez que foi dispensada a escritura pública e, conseqüentemente, a participação do notário. Essa facilidade decorria do fato de que o proprietário matriculado além de receber obrigatoriamente uma cópia da matricula (título), podia requerer ao oficial do registro um extrato das informações contidas no livro matriz que o possibilitaria alienar, hipotecar ou onerar o imóvel em qualquer lugar. Era o que dispunha o art. 63 do decreto 451-B de 1890, que também previa:

$\S 1^{\circ}$ Deste extracto se lançará nota no livro da matricula e no verso do título.

$\S 2^{\circ}$ A datar da entrega do extracto, nenhum acto de transmissão ou oneração do immovel se inscreverá na matriz, emquanto o dito extracto não se devolver ao official, para seis anullado, ou não se provar, por annuncios nos jornaes, durante um mez consecutivo, que se destruiu ou perdeu.

Em seguida o art. 64 do mesmo decreto determinava:

Art. 64. Para transferir ou hypothecar immovel, comprehendido no extrato de registro, redigir-se-hão dous exemplares do escripto de transmissão, ou da obrigação hypothecaria.

${ }^{211}$ Commentarios, Notas e Formulários sobre o Registro Torrens. Rio de Janeiro: Jacintho Ribeiro dos Santos, 1925. p. 161. 
$\S 1^{\circ}$ Ambos os exemplares serão apresentados ao official público, que tiver competencia para receber taes actos, e esse lançará a devida nota no verso do extracto do registro.

$\S 2^{\circ} \mathrm{A}$ transferência de propriedade, a obrigação hypothecaria e outro qualquer acto celebrado por esta fórma em relação ao immovel terão o mesmo valor, que os passados e inscritos no logar da situação da cousa.

$\S 3^{\circ} \mathrm{O}$ comprador, o credor hypothecario e qualquer cessionário, cujo nome for assim lançado no extracto do registro, terão os mesmos direitos, que si se houverem inscripto na matriz.

Esse sistema de fácil mobilização do título, apesar de previsto nos artigos acima transcritos do decreto, nunca foi utilizado na prática no Brasil. Tanto pela desconfiança e medo de fraudes, quanto pelo fato de não exigir escritura pública. Borges acreditava que muitos oficiais negar-se-iam a realizar o procedimento, o que acarretaria constantes buscas por autorização judiciária. Ademais, entendia que essa maneira de transferir a propriedade nunca teria aplicação entre os brasileiros, já que era contrária a seus costumes e sua mentalidade. ${ }^{212}$

Em 5 de novembro de 1890, foi promulgado o decreto n. 955-A que visava regular o decreto 451- B do mesmo ano. A nova norma, apesar de repetir alguns artigos da anterior, trouxe algumas inovações como a previsão da existência de outros livros diferentes do de matriz, seguindo entendimento já concretizado pelo decreto n. 370 de 1890 no referente ao registro geral. Assim, também quanto ao sistema Torrens foi previsto o livro de protocolo, de indicador real e pessoal (art. 14).

O livro de indicador real é o repertório de todos os imóveis, que direta ou indiretamente figurem no registro (art. 17). Já o pessoal, dividido alfabeticamente, é o local em que são inscritos por extenso os nomes de todas as pessoas que ativa ou passivamente, individual ou coletivamente, figurem nos livros do registro (art. 18).

Pelo indicador real, buscava-se pelo imóvel e obtinham-se todas as suas características, histórico e ônus que o gravavam. Já pelo indicador pessoal, a procura era feita pelo nome do proprietário. Tal previsão, já existente no relativo ao registro geral, tornou o sistema Torrens brasileiro bastante completo.

O indicador real é importante nos casos de transferência do imóvel para outro titular como, por exemplo, na compra e venda. "A" deseja comprar o imóvel "X", vai à

\footnotetext{
${ }^{212}$ O Registro Torrens no Direito Brasileiro. São Paulo: Saraiva, 1960. p. 33.
} 
serventia imobiliária e lá descobre todas as suas características, inclusive quem é o proprietário. Já o indicador pessoal é relevante quando o imóvel é usado em garantia. "A" faz um empréstimo a "B" e, pelo indicador pessoal, descobre se ele tem algum imóvel e se este está ou não gravado com algum ônus.

O decreto também relacionava o livro matriz e o registro geral. Aquele imóvel que passasse por todo procedimento necessário para a elaboração de sua matrícula, teria a partir de então todas as transcrições de suas transmissões, instituições de ônus reais e inscrições de hipotecas feitas nos livros do registro geral, com a anotação de que havia sido objeto do registro Torrens e, em seguida, seriam lançadas no livro matriz (art. 19 e 20).

Outra previsão interessante foi a do artigo 43, que definiu o que deveria ser compreendido como "terceiro". Para o decreto, terceiro era todo aquele que não fosse parte do contrato, nem seus herdeiros. O artigo ressaltava aos olhos de quem fazia a leitura da norma, afinal a abrangência da palavra "terceiro" havia sido objetos de discussões entre os intérpretes da Lei Hipotecária de 1864 (como já visto no item 2.4).

O decreto n. 955- A de 1890 trouxe também como inovação o art. 82 que previu a possibilidade de empréstimos a curto prazo, sem grandes complicações. O proprietário, ao adquirir o empréstimo com pagamento próximo, entregava o título da propriedade ao credor, em penhor. Esse direito de garantia era constituído simplesmente pela tradição do título ao credor pignoratício. Enquanto o credor estivesse com a posse do título, não era possível realizar alienações ou gravar o imóvel com hipoteca.

Quanto à transmissão de bens imóveis e os efeitos produzidos pelo registro, nada foi alterado do já previsto no decreto 451- B de 1890.

Segundo os elaboradores do decreto que instituiu o Registro Torrens na legislação pátria, vários autores discordavam da adoção desse novo sistema, no entanto, nenhum de seus argumentos se sustentavam. Primeiro diziam os opositores que sua aplicação seria impossível diante da situação caótica dos títulos de propriedade no país, fato que não acontecia na Austrália, região para o qual o sistema tinha sido criado. Para Ruy Barbosa, Manuel F. De Campos Sales e Francisco Glycerio, a afirmação era errônea, já que na Austrália as medições 
das propriedades também se apresentavam diferentes da realidade. Além disso, diziam que o Registro Torrens não poderia ser aplicado no Brasil devido a grande longevidade dos títulos, o que não ocorria na Austrália. Mais uma vez, o pensamento estava equivocado, uma vez que isso também estava presente na Austrália. Assim, utilizando-se da experiência dos outros países (principalmente da Austrália) os legisladores brasileiros afastavam qualquer oposição ao novo sistema. ${ }^{213}$

Traçados os principais aspectos e inovações das legislações brasileiras que regularam o registro Torrens, resta analisar o que elas previam sobre as transmissões da propriedade imóvel.

Toda transferência de imóvel matriculado deveria constar obrigatoriamente no livro matriz. $\mathrm{O}$ ato translativo do bem era tido como registrado, logo que se averbasse nele a informação de que se achava inscrito em sua matricula, com indicação do dia e hora em que foi apresentado (art. 16 caput e $\S 1^{\circ}$ ). Todo título assinado pelo oficial tinha fé pública, constituindo prova de que a pessoa nele nomeada era investida dos direitos que o documento especificava (art.18).

Antes do registro, o ato translativo de propriedade era ineficaz (art. 39, caput), já que a transcrição tinha efeito constitutivo e o simples acordo de vontades não era suficiente para transferir o domínio sobre o bem. Após o registro, o imóvel passava ao adquirente com todos os encargos e direitos constantes em sua matricula (art. 41, caput). Dessa maneira, o adquirente do imóvel ficava exonerado de reclamações relativas a direitos que não constassem do registro (art. 43). No entanto, era possível que aquele que acreditasse ter direito sobre o imóvel, apresentasse oposição à transferência, cabendo ao juiz decidir.

Ressalta-se que, em regra, nenhuma ação de reivindicação podia ser recebida contra o proprietário de imóvel matriculado (art. 75). Diz-se "em regra", porque a lei previu uma exceção ao conferir ação de reivindicação à vítima de uma matrícula fraudulenta contra o fraudador, desde que este fosse julgado criminalmente e aquela apresentasse título anterior devidamente inscrito no registro $\left(\operatorname{art} .75, \S 2^{\circ}\right)$. Contudo, se aquele que fraudasse a matricula já

213“"Exposição de motivos” in Lopes, Américo; Lopes, Cícero. Commentarios, Notas e Formulários sobre o Registro Torrens. Rio de Janeiro: Jacintho Ribeiro dos Santos, 1925. p. 26 e 27. 
tivesse alienado o bem a terceiro de boa-fé, este não podia ser perturbado em sua posse (art. $76, \S 2^{\circ}$ ). Dessa forma, restava à vítima da matricula fraudulenta acionar, por indenização, aquele que da fraude aproveitou-se (art. 76, caput), já que não mais teria direito sobre o imóvel.

A adoção do sistema Torrens pela legislação brasileira representou a busca por um modelo registrário que proporcionasse uma publicidade perfeita da situação jurídica da propriedade imóvel, facilitando a sua circulação e estimulando o crédito territorial. O abandono do aprimoramento do sistema comum, a aplicação de um novo modelo registrário e, principalmente, sua facultatividade, são emblemáticos. A criação de um regime paralelo de registro e de caráter facultativo aparece como uma solução simples e mediadora. De um lado, atende aos reclames daqueles que pleiteavam maior segurança ao crédito garantido por um imóvel e à transferência de domínio, de outro, não onerava, ou melhor, aborrecia, aqueles que não tinham qualquer interesse em fixar limites e dimensões do imóvel, e em estabeler com clareza os direitos ali existentes.

Com a previsão de uma matrícula, na qual o imóvel é individualizado, a exigência de registro de todos os atos de alienação e de constituição de ônus reais e a defesa do adquirente de boa-fé, mesmo no caso de fraude, pode-se afirmar que o Registro Torrens permitiu que duas das seguranças necessárias a um sistema registrário completo fossem garantidas. Assim, aqueles imóveis que passassem por todo procedimento que dava origem à matricula no livro matriz, podiam valer-se da segurança do crédito e do comércio. ${ }^{214}$

Do crédito, porque todos os direitos reais de garantia que recaíssem sobre o imóvel deviam ser inscritos na matrícula do bem, a qual fornecia as informações necessárias àquele que desejasse realizar negócio jurídico com o proprietário. Do comércio, porque o adquirente de boa-fé teria seu direito assegurado, mesmo que houvesse ocorrido fraude nas transferências anteriores, ou que por algum motivo fosse realizado o Registro Torrens de imóvel cujo direito real pertencesse à pessoa diferente da prevista no assento. Perceba-se que, para que a transcrição se preservasse, era fundamental que o adquirente estivesse de boa-fé, o que

\footnotetext{
${ }^{214}$ Para os autores do decreto 955-A de 1890 a segurança garantida pelo sistema Torrens é completa, tanto para o proprietário quanto para o terceiro. "Exposição de motivos" in LoPes, Américo; Lopes, Cícero. Commentarios, Notas e Formulários sobre o Registro Torrens. Rio de Janeiro: Jacintho Ribeiro dos Santos, 1925. p. 22.
} 
significa dizer que o sistema Torrens adotou uma das formas de execução do princípio da publicidade material, ou seja, o princípio da fé pública ou da proteção do comércio. ${ }^{215}$ Assim, as relações comerciais ficavam garantidas, e o direito do proprietário vítima de fraude ou erro era afastado e substituído por uma indenização, paga pelo fraudador, no primeiro caso, e pelo Estado no segundo.

Destaca-se que garantir a segurança do comércio e prever o pagamento de indenização para possíveis erros era uma maneira do Estado levar a população a confiar totalmente na assertividade do procedimento do Registro Torrens e, conseqüentemente, na veracidade dos dados contidos nos assentos registrais.

Quanto à segurança da propriedade, tudo indicaria que ela estaria presente, se todas as exigências para o registro pudessem ser cumpridas. Afinal, para realizar-se matrícula por meio do regime Torrens era fundamental que se fizessem planta e memorial descritivo, determinando com exatidão os limites e dimensões da propriedade e, principalmente, um histórico de todos os títulos de domínio. No entanto, cumprir essas determinações do decreto era quase impossível, mormente a segunda, e por mais que se conseguisse descrever corretamente o imóvel, objetiva e subjetivamente, o que levaria à crença de que a chance do não proprietário alienar o bem se tornasse diminuta, fraudes poderiam ocorrer. Dessa feita, a segurança da propriedade, que permitiria que o proprietário do bem tivesse assegurado seu direito sobre ele, mesmo no caso de fraude e, ainda que terceiro de boa-fé ou má-fé adquirisse imóvel do fraudador, não foi garantida. ${ }^{216}$ Essa assertiva se confirma, quando se verifica que por meio do fundo de garantia, o Estado pagava uma indenização ao real proprietário privado de seu direito por erro no procedimento de matrícula. Assim, ele perdia a propriedade, mas

\footnotetext{
${ }^{215}$ As duas formas de execução do princípio da publicidade material, o da fé publica e o da eficácia jurídica formal, serão estudados no próximo capítulo, no item 3.2 referente aos antecedentes do Código Civil de 1916. No momento basta distinguir a publicidade material e a formal. Segundo Regnoberto M. de MeLo JR. "A publicidade é material (ou de fundo) quando serve para proteger os interessados e terceiros no ato registrário, para afetar o bem jurídico registrado, para veicular a cognoscibilidade legal (dos assentos registrais), e constituir os direitos deles derivados. Já a noção de publicidade formal é orgânica. Seria esta o conjunto de serviços públicos que disponibilizam, a todos, as informações contidas nos assentos das repartições registrais". Lei de Registros Públicos Comentada. Rio de Janeiro: Freitas Bastos, 2003. p. 51.

${ }^{216}$ Para Borges "O registro Torrens é a via mais aconselhável de legislação, definitiva e absoluta, da propriedade imóvel, no Brasil. Prevenindo demandas, proporciona completa tranqüilidade e segurança aos proprietários". $O$ Registro Torrens no Direito Brasileiro. São Paulo: Saraiva, 1960. p. 143.
} 
recebia em contrapartida o valor correspondente do fraudador ou do Estado, ou seja, não tinha garantido o seu direito real.

Ao garantir a segurança do crédito e do comércio e ao prever uma compensação ao real proprietário pela perda do imóvel, esse sistema registrário pode ser analisado na linha histórica desenvolvida ao longo de todo este estudo como uma evolução diante dos aprimoramentos que trouxe. Apesar de ser adotado como regime paralelo ao comum, de possuir caráter facultativo e de ter sido pouco aplicado em todo o país (aparecendo apenas em alguns Estados), o registro Torrens influenciou o sistema comum, que mais tarde sofreu mudanças significativas, que culminaram na previsão da matrícula pela Lei de Registros Públicos de 1973.

Em suma, apesar de parecer um modelo registrário isolado no ordenamento brasileiro, o regime Torrens teve enorme influência na estruturação do modo de transmitir a propriedade imóvel pelo registro do título, principalmente no que se refere às seguranças que devem envolvê-lo.

\section{SEGURANÇA JURÍDICA DO DIREITO DE PROPRIEDADE $X$ SEGURANÇA JURÍDICA DO COMÉRCIO: POSIÇÃO DO DIREITO BRASILEIRO.}

\subsection{Contexto histórico}

No contexto histórico do primeiro capítulo, afirmou-se que não era possível no período do Império escrever sobre terras sem tratar sobre a mão-de-obra. Agora, no contexto da Primeira República (1889-1930) o binômio terra e mão-de-obra é afastado devido ao surgimento de outros fatores, como o início do desenvolvimento de novos setores produtivos, que atingem ora direta ora indiretamente a situação da propriedade imobiliária.

Com o fim do Império e a proclamação da República, em 15 de novembro de 1889, esperavam-se mudanças estruturais no país, não só pelas características que o novo 
regime incutia, mas também por grande parte da elite política imperial ter se afastado do poder.

O afastamento das oligarquias agrário-exportadoras, que dominavam o quadro político no período imperial, foi provisório e decorreu da presença dos militares, um novo setor da sociedade, no poder. De fato, os dois primeiros governos da República foram conduzidos por militares, Deodoro da Fonseca (1889-1891) e Floriano Peixoto (1891-1894), que parecem apresentar certa autonomia em relação às classes dominantes.

Apesar de não ter sido plena, essa certa autonomia é significativa quando se fala em Primeira República, uma vez que esse período histórico caracterizou-se pela influência política e econômica da mesma elite que dominou o país durante o Império, ou seja, a classe formada pelas oligarquias agrário-exportadoras. Essa pequena independência militar foi motivo de tensões entre os dois grupos durante o final do século XIX e início do século XX. A classe predominante não se conformava com o fato dos militares não participarem do aparelho de dominação oligárquica, o que significava não poder utilizá-los como instrumento de consolidação de uma política que preservasse sua hegemonia. Dessa maneira, durante a Primeira República, não houve aliança entre militares e oligarquia. ${ }^{217}$

Apesar do afastamento temporário durante o período dos governos militares e a falta do apoio desse novo grupo social, o aparelho de dominação oligárquica manteve-se forte com o novo regime. Isso aconteceu essencialmente pela manutenção da base econômica do país, que continuou a exportar matéria-prima e gêneros alimentares e a importar produtos fabricados. Como não houve alterações na economia, nem qualquer política de incentivo a outro setor, como por exemplo, as indústrias, a elite agrário-mercantil da região centro sul do país continuou prosperando. Diferenciava-se assim dos fazendeiros latifundiários do nordeste, que passando por um período de decadência na lavoura, eram obrigados a mandar seus filhos para os centros urbanos em busca de outro trabalho, seja no comércio ou indústria, ou ocupando cargos públicos, porque a agricultura já não mais proporcionava os lucros de outrora.

${ }^{217}$ Pinheiro, Paulo Sérgio et al. O Brasil Republicano: sociedade e instituições (1889-1930). $8^{\mathrm{a}}$ ed., Rio de Janeiro: Betrand Brasil, 2006. p. 36 e 37/vol.9. 
Essa diferença entre as "oligarquias" do norte e sul do país gerou, ao longo dos anos, conflitos políticos entre os dois grupos que, ao contrário do que possa parecer, não tinham muitos interesses em comum. Enquanto os fazendeiros do sul desejavam aumentar a produtividade com a adoção de maquinário e novas formas de produção, os do norte ainda cultivavam da maneira tradicional, sem realizarem maiores investimentos. ${ }^{218} \mathrm{O}$ conflito entre os dois grupos refletiu-se em modificações nas alianças políticas durante a Primeira República, sem, contudo alterar o domínio das classes oligárquicas.

Além da manutenção da base econômica do país, o poderio da classe dominante deveu-se à utilização dos ideais republicanos a seu favor. Dessa forma, a instituição da democracia representativa e do sufrágio universal masculino, que poderiam arejar a composição política, foram utilizados pela oligarquia agrário-exportadora para legitimar o seu poder. ${ }^{219}$ Afinal, foi com a democracia representativa ${ }^{220}$ que frutificaram figuras como o “coronelismo", mecanismo que permitiu a manutenção de representantes da classe dominante nos mais altos postos da política. ${ }^{221}$

A legislação eleitoral republicana foi importante para manter o mandonismo local, na medida em que ao estender o direito de voto a todos os alfabetizados, ampliou o sistema em que o voto era uma moeda de troca, ${ }^{222}$ incluindo no processo outros níveis da hierarquia

${ }^{218}$ Referindo-se as diferenças entre o que chama de "dissidências internas no bloco do poder", Paulo SérGio PINHEIRo enumera as diferenças entre os dois grupos na segunda metade do século XIX da seguinte forma: "economia escravagista versus economia exportadora baseada na mão-de-obra livre (no final do Império), produtores exportadores capitalistas do Centro-Sul versus coronéis controlando latifúndios de baixa produtividade, alianças políticas regionais versus desencadeamento do processo de intervenção e de centralização do Estado". Ibidem., p. 34.

${ }^{219}$ O jurista José Augusto CESAR já em 1913 parece perceber o uso pelas oligarquias agrário-exportadoras, que chamava de "burguesia", de figuras introduzidas pela República para sua manutenção no poder ao escrever "Entre nós domina despoticamente uma burguezia avassaladora que chegou a transformar o novo governo em instrumento das suas criminozas especulações. Sob a aparência de uma democracia pura, eziste aqui a mais real das plutocracias". Prefácio sobre o projeto de Código Civil. In: Ensaio sobre os actos jurídicos. Campinas: Typ da Casa Genoud, 1913. p. 6.

${ }^{220}$ Segundo OrLANDO GOMES, com a deformação do sistema representativo pela política da clientela eleitoral "Os grandes proprietários praticamente nomeavam os legisladores e governadores em farsas eleitorais". Raízes históricas e sociológicas do Código Civil Brasileiro. São Paulo: Martins Fontes, 2003. p. 27 e 28.

${ }^{221}$ Pinheiro, Paulo Sérgio et al. O Brasil Republicano: sociedade e instituições (1889-1930). $8^{a}$ ed., Rio de Janeiro: Betrand Brasil, 2006. p. 40/vol.9.

${ }^{222}$ Segundo Queiroz "Era 'normal', no período das eleições, saírem os chefes políticos e seus cabos eleitorais em tournées pelo interior, carregados de presentes para os eleitores - botinas ringideiras para os homens, cortes de vistosa chita para as mulheres da família do eleitor, roupas e brinquedos para as crianças, sendo que, num envelope, juntamente com a cédula de voto, havia outras de mil-réis... Saboroso folclore eleitoral até agora pouco conhecido e pouco levado em consideração, mas que tem um significado patente, pois revela uma verdadeira 'compra' do voto". O coronelismo numa interpretação sociológica. In: Fausto, Boris (direção). O Brasil 
social. ${ }^{223}$ Em outras palavras, o aumento no número de eleitores apenas fez ampliar a quantidade daqueles que votavam de acordo com os interesses do "coronel" da região, estando estes agora mais dispersos entre as classes sócio-econômicas.

No entanto, a ampliação do quadro de eleitores não foi muito grande, já que boa parte da população não tinha qualquer instrução. Assim, como aqueles que tinham direito de voto formavam um grupo restrito, foi possível manter a barganha eleitoral. ${ }^{224}$

Tendo o número de eleitores aumentado, mas não o suficiente para que se perdesse o controle sobre eles, os chefes políticos continuaram a utilizar a barganha ou a violência para escolher aqueles que ocupariam os cargos eletivos (Câmara Municipal, Presidência do Estado, Senado), ou seja, seus parentes, aliados e protegidos. ${ }^{225}$

Como tinham nos principais postos de comando, pessoas que defendiam seus interesses, a classe oligárquica controlava o Estado. ${ }^{226}$ Assim, aos poucos, foram-se adotando medidas que contribuíram para o incremento das exportações de matéria-prima, como, por exemplo, a centralização política. Além de facilitar o controle pela classe oligárquica, ela permitiu uma maior participação do Estado em alguns setores da produção, defendendo o café, gênero de maior importância na pauta de exportações. Com as decisões centralizadas, diminuiu-se consideravelmente a autonomia de cada unidade da federação.

Esse movimento era inverso ao que fora imaginado quando da promulgação da primeira Constituição Republicana em 1891, que tinha como característica principal a

Republicano: estrutura de poder e economia (1889-1930). Rio de Janeiro: Bertrand Brasil, 2006, p. 178/vol.8.

${ }^{223}$ Ibidem., p. 178 e 180.

${ }^{224}$ Ibidem., p. 180.

${ }^{225}$ Ibidem., p. 172

${ }^{226}$ Queiroz retrata bem esta situação e mostra o que aconteceu alguns anos mais tarde ao escrever "A transferência tivera início já durante o século XIX; porém, tratava-se então de elementos da classe média que agiam como representantes e como subordinados dos grandes chefes políticos, os quais preferiam permanecer exclusivamente à testa de seus negócios ou de suas fazendas. Porém, nesta fase, o abandono do poder político pelos coronéis não era senão aparência; as camadas médias surgiam em cena, mas nos bastidores os grandes grupos das antigas parentelas governavam o jogo político, alijando e rejeitando aqueles de seus representantes que não lhes pareciam suficientemente devotados ou leais. Mas à medida que as camadas médias urbanas se adensavam, sua possibilidade de uma atuação política independente crescia; todavia, não foi sem luta que alcançaram um instrumento que lhes permitia ter os movimentos mais livres - instrumento representado pelo voto secreto, em torno do qual se travaram verdadeiras batalhas políticas na década de 20 ". O coronelismo numa interpretação sociológica. In: Fausto, Boris (direção). O Brasil Republicano: estrutura de poder e economia (1889-1930). Rio de Janeiro: Bertrand Brasil, 2006. p. 206 e 207/vol.8. 
descentralização do poder. $\mathrm{Na}$ realidade, era inclusive contrário ao que se esperava com a proclamação da República, já que, como afirma Celso Furtado, ela consistiu um movimento de reivindicação da autonomia regional. ${ }^{227}$

O novo diploma constitucional previu medidas descentralizadoras; o Brasil passou a ter um sistema federativo em que cada Estado (até então chamado de Província- art. $1^{\circ}$ e $2^{\circ}$ ), além de eleger diretamente seu próprio governador e deputados, passou a ter maior autonomia com a possibilidade de arrecadar impostos estaduais (art. $9^{\circ}$ ). No relativo as terras, as devolutas passaram a pertencer ao Estado em que se encontravam e não mais a União (ou Império), como na Carta Constitucional de 1824 (art. 64 da Constituição Republicana). ${ }^{228}$

Nos vinte primeiros anos da República, uma maior independência dos Estados levou-os a assumir um papel fundamental na política econômico-financeira do país. Uma reforma monetária, elaborada em 1888, mas somente posta em prática no governo provisório, permitiu que bancos regionais emitissem dinheiro, o que levou a uma considerável expansão do crédito. ${ }^{229} \mathrm{O}$ aumento na oferta de crédito, por muito tempo artigo raro na economia nacional, proporcionou um incremento nas atividades produtivas, fazendo desenvolver outros setores econômicos. No entanto, esse desenvolvimento não foi grande o bastante para afastar a hegemonia agrário-exportadora.

Assim, apesar da Constituição de 1891 ter disciplinado um Estado descentralizado, dando maior poder aos Estados membros, na prática, essa autonomia foi logo eliminada pelos interesses da classe dominante que desejava um governo centralizado, principalmente para a proteção do café.

A centralização política exigiu um aumento na estrutura do Estado, com a conseqüente criação de inúmeros cargos públicos. Esses foram, aos poucos, sendo utilizados como moeda de troca, sendo cedidos principalmente à classe média, que nessa função passou a defender e proteger os interesses de grandes fazendeiros e comerciantes.

\footnotetext{
${ }^{227}$ Formação Econômica do Brasil. 23a ed., São Paulo: Nacional, 1989. p. 171.

${ }^{228}$ Milton, Aristides A. A Constituição do Brazil. Noticia histórica, texto e commentario. $2^{\text {a }}$ ed., Rio de Janeiro: imprensa Nacional, 1898. p. 5, 10 e 335.

${ }^{229}$ Furtado, Celso. Formação Econômica do Brasil. 23a ed., São Paulo: Nacional, 1989. p. 171.
} 
Como afirma Paulo Sérgio Pinheiro, escrever sobre a classe média na Primeira República é escrever sobre ambigüidades. Composta por pequenos comerciantes e industriais, artesãos, alfaiates, sapateiros, funcionários públicos, assalariados e outros ${ }^{230}$, era extremamente heterogênea e vazia de significado. Era heterogênea, porque composta pelos mais diversos tipos, seja por pequenos fazendeiros desiludidos com a lavoura, imigrantes e seus descendentes que desejavam enriquecer, ou membros de famílias proprietárias decadentes que buscavam novo ofício nas cidades. Era vazia de significado, por não possuir ideologia própria, incorporando todos os ideais e valores da classe dominante. ${ }^{231}$

Pertencendo à estrutura de dominação oligarquia, a classe média não agiu em nenhum momento durante toda a Primeira República de maneira autônoma, sempre atuou ao lado das classes dominantes, representando-as. Seu objetivo principal era aproveitar-se dessa proximidade para obter privilégios e prerrogativas até então pertencentes unicamente a classe superior, inclusive a de autoridade e mando. ${ }^{232}$

Algumas manifestações atribuídas à classe média, como a Revolta da Vacina, em 1904, a campanha civilista, em 1909, as rebeliões tenentistas nos anos de 1920 e a Revolução de 1930, fazem parecer errada a afirmação de ausência de autonomia nesse grupo social, uma vez que esses acontecimentos simbolizariam uma oposição à classe dominante. ${ }^{233}$

No entanto, conforme afirma PINHeIRo, o afrontamento no campo político não significou antagonismo, já que os interesses econômicos dos dois grupos eram os mesmos, assim como o quadro ideológico. A classe média só se afastava um pouco da classe agrárioexportadora quando pregava o antiintervencionismo. Receavam que o controle da classe dominante sobre o Estado pudesse, de alguma maneira, gerar mudanças na sociedade, atingindo o seu status quo. ${ }^{234}$ Dessa forma, a classe média era a grande defensora da manutenção da sociedade como estava, solidificando-se as tradições. ${ }^{235}$

${ }^{230}$ O Brasil Republicano: sociedade e instituições (1889-1930). $8^{\text {a }}$ ed., Rio de Janeiro: Betrand Brasil, 2006. p. 21/vol.9.

${ }^{231}$ Ibidem., p. 42.

${ }^{232}$ Pinheiro, Paulo Sérgio et al. O Brasil Republicano: sociedade e instituições (1889-1930). $8^{\text {a }}$ ed., Rio de Janeiro: Betrand Brasil, 2006. p. 42 e 43/vol.9.

${ }^{233}$ Ibidem., p. 34.

${ }^{234}$ Ibidem., p. 34 e 41.

${ }^{235}$ Mesmo quando defendiam mudanças, a classe média intelectualizada esbarrava no vínculo que tinha com a oligarquia. Segundo Emília Viotti da Costa "Localizando suas atividades nos centros urbanos mais importantes, 
O estranho é imaginar que essa classe social tão avessa às mudanças era a mais intelectualizada do país, compondo o grupo dos "doutores". Mas o estranhamento desaparece quando se percebe que, para essa categoria, a formação superior mais do que uma busca pelo conhecimento e aprimoramento era uma maneira de aproximar-se da burguesia e diferenciarse do proletariado.

O comportamento da classe média, que apesar de intelectualizada, não tinha ideologia própria e agia de acordo com os interesses da classe agrário-exportadora refletiu-se no direito e, especificamente, na regulamentação da transmissão da propriedade imóvel. Isso porque o principal monumento legislativo do final do século XIX e início do século XX, o Código Civil de 1916 foi obra desse grupo social, que estava atrelado à classe agrárioexportadora. $^{236}$

Assim, se houvesse algum grupo de juristas mais independente, que desejasse elaborar uma legislação liberal e progressista, era convencido pelos fazendeiros a manter as tradições. $^{237}$ Orlando Gomes ressaltava que, na época da elaboração do Código Civil, chegaram ao Parlamento propostas de leis que visavam regular a indenização em caso de acidente de trabalho. Assim, tentavam introduzir no país legislação de matéria social que era naquele momento muito debatida na Europa. Apesar de alguma influência européia ter

onde o contato mais íntimo com a cultura européia e com a vida urbana lhes dava relativo distanciamento da realidade rural, opunham-se, às vezes, teoricamente, ao domínio das oligarquias, denunciando a opressão que estas exerciam sobre as populações rurais e urbanas. Criticavam o latifúndio, a escravidão; preconizavam métodos de ensino mais modernos. Continuavam, no entanto, na dependência das oligarquias que queriam combater, ocupando cargos púbicos para os quais eram nomeados por interferência de elementos da oligarquia, escrevendo em jornais e revistas, publicando livros que se destinavam a um público leitor cujos limites não ultrapassavam muito os da oligarquia ou dos grupos urbanos que compunham sua clientela. Alguns vivendo nas cidades que se modernizavam rapidamente tenderiam a não ver a realidade mais ampla que estava atrás das fachadas modernas e das instituições políticas importadas, esquecendo-se de que o sertão ainda governava o país". Da Monarquia à República: momentos decisivos. 8ª ed., São Paulo: Fundação UNESP, 2007. p. 264 e 265. ${ }^{236}$ Gomes, Orlando. Raizes históricas e sociológicas do Código Civil Brasileiro. São Paulo: Martins Fontes, 2003. p. 30.

${ }^{237}$ Parece que José Augusto CesAR, apesar de também jurista, não acreditava na existência entre seus pares de um grupo liberal e progressista, já que em 1913 escreveu "Os principaes mentores da nossa burguezia são os juristas. Ora, notavel pensador já assinalou com perfeita justeza a parcialidade e o egoísmo dessa classe de intelectuais. Ao passo que os medicos e os economistas tão gloriosamente se empenham em minorar a miseria humana, os juristas se incorporam ao sequito dos abastados e poderozos, cujos interesses defendem com zelo e fatuidade. Sem duvida não foi pequena sua parte nas cruzadas contra o absolutismo e os antigos processos de opressão; mas, uma vez estabelecido o rejimen constitucional e firmada a liberdade política, elles abandonaram a causa dos pobres, que agora procuram iludir com formulas gastas e estafadas - republica, federação, direitos fundamentaes e outros nada sonoros". Prefácio sobre o projeto de Código Civil. In: Ensaio sobre os actos jurídicos. Campinas: Typ da Casa Genoud, 1913. p. 6. 
chegado ao Brasil, o Código Civil manteve-se fiel ao individualismo jurídico que estava mais de acordo com o "grau de desenvolvimento das forças produtivas no país". ${ }^{238}$

Segundo o mesmo autor, a opção pelo individualismo jurídico foi consciente. As classes abastadas queriam uma legislação que contribuísse para o desenvolvimento das forças produtivas do país no modo do sistema colonial de riquezas. Assim, não seria interessante que se criasse um direito privado que onerasse a produção. ${ }^{239}$

Referindo-se ao individualismo, Clóvis Bevilaqua afirmou que o direito privado social deveria ser o equilíbrio entre os interesses do indivíduo e da sociedade, disciplinando as relações entre as classes. Assim, qualquer reforma na legislação deveria ser feita dentro destes limites, caso contrário seriam vistas como "subversivas". 240

Bevilaqua também ressaltava que o individualismo só deveria ser evitado naquilo que tivesse de "exaggeradamente egoístico e de desorganizador". Mas tais aspectos não eram piores do que adotar um socialismo "absorvente e anniquilador dos estímulos individuaes". Segundo o autor, esse socialismo nada mais era do que aquele que tinha sido apresentado nos últimos anos como solução das incertezas do presente e era explicado pela sociologia. Diferia assim daquela "anarchia mental" que trabalha pela eliminação da propriedade, da família e do governo, sem saber ao certo o que os substituirá, e que vinha causando inquietação, constrangimento e revolta. ${ }^{241}$

Para Gomes, o "socialismo" de que fala Bevilaqua nada mais era que o movimento que poucos anos depois reconheceu a existência de direitos sociais. Para ele, o jurista

\footnotetext{
${ }^{238}$ Raízes históricas e sociológicas do Código Civil Brasileiro. São Paulo: Martins Fontes, 2003. p. 31 e 33.

${ }^{239}$ Ibidem., p. 34.

${ }^{240}$ Ao escrever sobre o trabalho do codificador e sua relação com as inovações legislativas, o autor afirmava: “As codificações sempre foram mais trabalho de depuração, de condensação, de enfeixamento, de classificação, de methodisação, do que aventurosos transitos, por sendas mal desbravadas. Em relação ás regras jurídicas, que se tornaram vetustas, absoletas, o codificador e o consolidador assumem a mesma posição, usando ambos do processo da eliminação. Em frente ás novas formações, ou estas já rasgaram sulco no organismo social, e cabe ao codificador abrir-lhes espaço no seu systema, cercando-as de protecção legal, ou ainda se acham mal definidas, vacillantes, e é dever do codificador, si as divisas deixar-lhes o caminho aberto para que se desenvolvam e preencham a funcção social a que se destinam para que vicem, si merecem vigor. Injectar-lhes seiva, caso não tenham por si, poderá ser uma intervenção funesta na economia da vida social. É preciso, pois, marchar muito cautelosamente por esses terrenos, cujas orlas ainda ensombra o desconhecido. Em Defeza do projecto de Código Civil Brazileiro. Rio de Janeiro: Francisco Alves, 1906. p. 40 e 41.
}

${ }^{241}$ Ibidem., p. 41 e 42. 
confundia o socialismo ideologia com o anarquismo e posicionava-se contrário à introdução no Código Civil de qualquer dispositivo de cunho social. ${ }^{242}$

Já para Ignácio Maria Poveda Velasco, o projeto convertido em Código apresentava preocupações sociais, que podem ser expressas pela regulação do contrato de locação de serviços, a previsão do reconhecimento dos fillhos ilegítimos e a investigação de paternidade. ${ }^{243}$

De qualquer forma, em nenhum momento no trâmite legislativo, o projeto de Código Civil foi acusado de não versar sobre a questão social. ${ }^{244}$ Bevilaqua só se preocupou em escrever sobre o assunto porque durante a discussão do Código Civil alemão, entrou em pauta o aspecto social e em suas disposições viram-se algumas nuanças de socialismo. Assim, o autor do projeto brasileiro imaginou que a situação pudesse ser repetida no Brasil, ou seja, que os juristas questionassem em que medida houve preocupação em atender às exigências sociais, o que não aconteceu. ${ }^{245}$

Como o Código Civil visou atender aos interesses da classe dominante, ${ }^{246}$ que eram essencialmente a manutenção do direito existente, sem muitas inovações, o direito privado brasileiro acabou preservando a tradição lusitana. ${ }^{247}$ Segundo OrLando GomEs, a aproximação brasileira às tradições portuguesas derivou muito do fato de que a sociedade da

${ }^{242}$ Raízes históricas e sociológicas do Código Civil Brasileiro. São Paulo: Martins Fontes, 2003. p. 35.

${ }^{243}$ Três vultos da cultura jurídica brasileira: Augusto Teixeira de Freitas, Tobias Barreto de Menezes e Clóvis Bevilaqua. In: BitTar, Eduardo C. B. (Org.). História do Direito Brasileiro. Leituras da Ordem Jurídica Nacional. São Paulo: Atlas, 2003. p.41.

${ }^{244}$ José Augusto Cesar censurava esta postura ao escrever em 1913 “Acredito que até agora ninguém criticou o projeto sob o ponto de vista social e econômico. Não se pode justificar essa ausência com o pequeno número de proletariados porque é inegável existirem aqui os mesmos males que provocaram o movimento socialista no velho mundo. Assim não é apenas uma questão de legislar para o futuro, o projeto não conseguiu nem mesmo atender as exigências da atualidade". Prefácio sobre o projeto do Código Civil in Ensaio sobre os actos jurídicos. Campinas: Typ da Casa Genoud, 1913. p. 7 e 8.

${ }^{245}$ GOMES, Orlando. Raizes históricas e sociológicas do Código Civil Brasileiro. São Paulo: Martins Fontes, 2003. p. 37.

${ }^{246}$ Nesse sentido José Augusto CÉSAR, para quem "Entre os colaboradores do projeto de codigo, não há nenhum compenetrado dos ideaes modernos. São todos elles, principalmente os congressistas, órgãos das classes dirijentes. As classes populares, portanto, não se fizeram reprezentar na preparação de trabalho de tanta magnitude. O projecto (...) só viza servir os detentores dos bens". Prefácio sobre o projeto do Código Civil. In: Ensaio sobre os actos jurídicos. Campinas: Typ da Casa Genoud, 1913. p. 6.

${ }^{247}$ Segundo Paulo de Lacerda, Bevilaqua manteve apenas as tradições que estavam "vivas no organismo da nação", apesar da existência de correntes contrárias no próprio país desejando mudanças, por isso nenhuma alteração no relativo ao divórcio e à liberdade de testar. Ao mesmo tempo, regulou preceitos liberais que já compunham os costumes, o que permitiu que novas necessidades sociais fossem atendidas. Codigo Civil Brasileiro. Rio de Janeiro: Jacintho Ribeiro dos Santos Editor, 1916. p. LIX e LXI. 
ex-colônia no início do século XX ainda se parecia muito com aquela que, em 1603, recebeu as Ordenações Filipinas em Portugal, tendo quase as mesmas condições e formas de vida. ${ }^{248}$

De fato, o Brasil não tinha sofrido grandes mudanças desde o período colonial. A população concentrava-se principalmente no campo, as cidades começavam a se desenvolver (mormente as portuárias com o incremento nas importações e exportações). A capital iniciava um período de renascimento com a adoção de uma série de medidas que buscavam europeizála, substituindo aquele aspecto colonial que, por tantos anos, afastou os estrangeiros: ruas estreitas e tortuosas, inúmeros cortiços, doenças e seus fortes odores. ${ }^{249}$

Quanto à industrialização, esta era na Primeira República incipiente. Iniciada nas últimas décadas do século XIX, foi resultado do crescimento do mercado interno e visou substituir as importações. A expansão do mercado interno derivou da pequena urbanização por que passou o país, principalmente devido à abolição da escravatura, imigração e ao aumento dos transportes. 250

Sendo pequeno o movimento industrial, a classe operária ainda era diminuta, não representando uma força política de renovação, nem encontrando apoio em outra classe social. $^{251}$

Em suma, como na Primeira República não houve grandes alterações na economia e principalmente na sociedade, que continuava com o mesmo pensamento e as mesmas ambições, o direito privado não sofreu modificações significativas, mantendo-se em regra, as tradições da época colonial. Diz-se "em regra" porque é possível observar modificações relevantes em algumas matérias, como, por exemplo, na referente ao direito de crédito e à transmissão da propriedade imóvel (como será visto nos itens seguintes). ${ }^{252}$ Mudanças nesse

\footnotetext{
${ }^{248}$ Raízes históricas e sociológicas do Código Civil Brasileiro. São Paulo: Martins Fontes, 2003. p. 10.

${ }^{249}$ Skidmore, Thomas E. Uma história do Brasil. São Paulo: Paz e Terra, 1998. p. 109.

250 "Em 1880, havia 18.100 pessoas registradas como operários. Um recenseamento de 1907 registra 2.983 estabelecimentos industriais e uma população de 136.420 pessoas dedicadas a essas atividades. (...) Ao lado de indústrias que contavam com trezentos operários ou mais, funcionavam as pequenas oficinas com alguns poucos operários que também eram arrolados pelo censo como indústrias, o que torna difícil de avaliar a real importância do operariado industrial da época". Viotтi da Costa, Emília. Da Monarquia à República: momentos decisivos. $8^{\mathrm{a}}$ ed., São Paulo: Fundação Editora UNESP, 2007. p. 259 e 269.

${ }^{251}$ Ibidem., p. 270.

${ }^{252}$ Interessante a observação de José Augusto CESAR quanto à importância dessas matérias para o direito privado "A elaboração jurídica moderna realizou-se em torno do credito, cujas ezijencias o desenvolvimento da riqueza movel em suas diferentes formas multiplicou extraordinariamente. A' solidez e á celeridade das tranzações
} 
sentido não surpreendem, uma vez que as exigências por segurança do crédito e rapidez nas transações existiam desde o período imperial, sendo perseguidas há tempos por parte da oligarquia agrário-exportadora, que ditou seus desejos durante toda a Primeira República.

\subsection{Antecedentes do Código Civil de 1916.}

A publicação da Consolidação das Leis Civis entregue ao Governo em 1857 por TeiXeira de Freitas foi o último trabalho que compôs os preparativos para a reforma da legislação civil. Ao reunir os atos normativos vigentes no país, em um único monumento legislativo, a Consolidação era vista como um trabalho de simplificação, de organização sistemática para posterior elaboração do Código Civil. ${ }^{253}$

Em 1859, Teixeira de Freitas foi contratado para apresentar no prazo de três anos um projeto de Código Civil. Na medida em que os tomos ficavam prontos eles eram publicados, dando origem ao que se denominou de Esboço. Os artigos 3.703 a 4.908, relativos aos direitos reais, vieram a público em $1865,{ }^{254}$ depois de apenas um ano da promulgação da Lei Hipotecária.

Nesse mesmo ano, uma Comissão Revisora foi instalada para analisar o projeto, mas a discussão não ultrapassou o artigo 15. A justificativa para a suspensão do trabalho era de que o Anteprojeto não estava pronto nem impresso, no entanto, o motivo era outro. A Comissão temia não conseguir completar sua tarefa, uma vez que o Anteprojeto apesar de ainda não concluído, já possuía 3.700 artigos. Mesmo com a ameaça de ter seu trabalho abandonado, TeixeIra de Freitas continuou a elaborá-lo até o $7^{\circ}$ e último tomo no artigo 4.908, faltando apenas a publicação de 308 artigos. ${ }^{255}$

complexas da vida hodierna sacrificam-se ilações de preceitos jurídicos fundamentaes. Ora, as instituições de credito, o comercio bancario, os negocios industriaes... constituem monopólio da burguezia, classe preponderante em quazi todas as nações civilizadas da atualidade. Pode-se, pois afirmar sem ezagero que o direito privado hoje vijente em quazi toda a Europa e na América é o resultado de um compromisso estipulado entre os grupos dominantes e imposto ás classes pobres por intermédio do Estado". Prefácio sobre o projeto do Código Civil. In: Ensaio sobre os actos jurídicos. Campinas: Typ da Casa Genoud, 1913. p. 5.

${ }^{253}$ Consolidação das Leis Civis. Rio de Janeiro: Typographia universal de Laemmert, 1865. p. I.

${ }^{254}$ Idem. Esboço do Código Civil. Brasília: Ministério da Justiça. Fundação Universidade Brasília, 1983. p. $\mathrm{XV} /$ vol.I.

${ }^{255}$ Ibidem., mesma página. 
Em 1867, o Ministro Martim Francisco afirmou que o governo estava muito satisfeito com o trabalho elaborado pelo jurista e que terminado o Código Civil, seria encomendado um Código Comercial. Mas não era esta a intenção de TeIXeIRA DE Freitas. Com o Esboço quase concluído, o jurista que havia sido contratado para organizar um Código Civil aos moldes da Consolidação, passou a defender a elaboração de um Código Geral, no qual constariam definições e regras de publicação, interpretação e aplicação das leis, e um Código Civil dispondo sobre matéria civil e comercial. Assim, pediu autorização ao governo para que fizesse as mudanças necessárias e dilação no prazo de entrega. ${ }^{256}$

Em 1865, o Ministro da Justiça José DE Alencar afirmou que o contrato com TeiXeira de Freitas estava rescindido, já que os prazos para a conclusão, 1861 prorrogado para 1864, não haviam sido cumpridos. Ademais, discordava da proposta do jurista e defendia o uso da própria Consolidação com algumas alterações. Três anos mais tarde, a Seção de Justiça do Conselho de Estado, contrariando a manifestação do Ministro, publicou parecer apoiando a proposta de Teixeira de Freitas e sugerindo a prorrogação do prazo de entrega do Código. Apesar do parecer favorável, o novo Ministro da Justiça, Duarte de Azevedo, confirmou a rescisão contratual, afirmando que era necessário agilizar a elaboração do Código Civil. Concordando com a rescisão, TeIXeIRA DE Freitas não terminou o Esboço, que acabou por se constituir em uma obra meramente doutrinária. ${ }^{257}$

$\mathrm{Na}$ verdade, o Esboço foi menosprezado por muitos, acredita-se que pelo fato dele não servir à aplicação imediata. Inclusive seu próprio autor, não o considerava como o projeto encomendado. $^{258}$

Mesmo não tendo sido aplicado na prática, não há como desconsiderar a sua existência, até porque muitos dos dispositivos do Esboço foram aproveitados pelo Código

\footnotetext{
${ }^{256}$ Esboço do Código Civil. Brasília: Ministério da Justiça. Fundação Universidade Brasília, 1983. p. XVII e XLIX/vol.I.

${ }^{257}$ Ibidem., p. XVIII.

${ }^{258}$ Ibidem., mesma página.
} 
Civil de 1916. ${ }^{259}$ Diante de sua relevância, torna-se fundamental verificar o que ele dispunha no relativo à transmissão da propriedade imóvel.

Analisando os dispositivos do Esboço, constata-se que não houve grandes inovações sobre a matéria se comparado com o que vigia desde o momento em que a interpretação do artigo $8^{\circ}$ da Lei Hipotecária de 1864 foi consolidada. A transmissão de bens imóveis inter vivos continuava a depender da transcrição do instrumento público no Registro (art. 3.809). Mantinha-se também o entendimento de que não era necessário transcrever títulos de transmissão causa mortis, o que impossibilitava a formação de uma cadeia contínua de proprietários. Apesar das reproduções, o Esboço trouxe inovação à matéria, ao exigir para a aquisição de direitos reais sobre imóveis transmitidos em virtude de atos judiciais, a inscrição das cartas de arrematação e adjudicação entre outros no Registro Conservatório (Art. 3.742). ${ }^{260}$

Assim, se o Esboço fosse aplicado, uma das lacunas referentes à transmissão de bens imóveis estaria solucionada; afinal, não só seriam aceitas no Registro escrituras públicas e instrumentos particulares de transmissão, mas também atos judiciais. Porém, essa obra nem se transformou em ato normativo, nem influenciou as leis esparsas surgidas sobre esse tema alguns anos mais tarde. Como já foi visto no capítulo anterior, os decretos ns. 169- A e 370 de 1890, não incluíram entre seus dispositivos, a exigência de transcrição dos atos judiciais para transferência de domínio, falha que apenas será resolvida pelo Código Civil de 1916.

Não sendo o Esboço utilizado como Anteprojeto de Código Civil, mais uma vez os parlamentares brasileiros viram-se distantes da codificação da matéria, que continuaria ainda por alguns anos apenas sistematizada. Porém políticos e juristas não desistiram de sua elaboração, tendo surgido uma série de projetos a respeito.

Assim, após a publicação da obra de Teixeira de Freitas, José Tomás Nabuco de Araúso foi encarregado, em 1872, de elaborar um Código Civil. Buscando sintetizar a obra de seu antecessor com a inclusão de alguns dispositivos de sua autoria, o autor apenas chegou a

259 Segundo Pontes de Miranda, "Das aproximadamente 1.929 fontes do Código Civil, ao direito anterior pertencem 479, á doutrina já vigente antes do Código Civil, 272, e ao Esboço de Teixeira de Freitas, 189. Isto quer dizer: em tudo que se alterou, foi o Esboço a fonte principal". Fontes e evolução do Direito Civil Brasileiro. Rio de Janeiro: Pimenta de Mello \& C., 1928. p. 119.

${ }^{260}$ Teixeira de Freitas, Augusto. Esboço do Código Civil. Brasília: Ministério da Justiça. Fundação Universidade Brasília, 1983. p. 543 e 550/vol.II. 
escrever 118 artigos do título preliminar e 182 da parte geral, falecendo logo depois ${ }^{261}$ Como não houve a elaboração da parte especial, a matéria referente à aquisição da propriedade imóvel pelo registro do título não chegou a ser abordada.

Com a morte de Nabuco, Joaquim Felício dos Santos ofereceu-se para continuar a obra inacabada, apresentando ao Governo, em 1881, seus "Apontamentos para projecto do Codigo Civil Brazileiro". A Comissão criada pelo governo para analisar a obra concedeu parecer favorável, concluindo pela utilização do trabalho como base para um projeto definitivo. Como as discussões na Comissão não progrediam, Felício dos SANTos apresentou os "Apontamentos" como projeto de Código Civil à Câmara dos Deputados em 1882. Com a proclamação da República, a análise dos dispositivos acabou sendo abandonada, postergando mais uma vez a criação de um Código Civil. ${ }^{262}$

O Projeto de Felício dos SAntos, no que é relativo à transmissão de bens imóveis, inclinava-se ao sistema registrário francês, exigindo apenas o contrato para sua transferência entre as partes contratantes. ${ }^{263}$ Em relação a terceiros, a transferência só produzia efeitos após a transcrição. Dessa forma, o intuito da transcrição era dar publicidade às transmissões, protegendo os interesses de terceiros; afinal, era importante que tanto os credores quanto aqueles que desejassem adquirir a propriedade do bem, soubessem a quem pertencia o imóvel e se ele estava gravado com algum ônus real. Nesse sentido o projeto previa:

“Art. 2668. - Não opéra seus effeitos em relação a terceiros senão pela transcripção e desde a sua data, a transmissão entre vivos da propriedade immovel, e a instituição entre vivos dos ônus reaes, de que trata o art. 2671.

Art. 2669. - A falta de transcripção dos actos, de que trata o artigo antecedente, não impede que elles produzam todos os seus effeitos entre as proprias partes e seus herdeiros.

Art. 2670. - A transcripção não induz á prova do domínio, o qual fíca salvo a quem pertencer." (...)

\footnotetext{
261 Poveda Velasco, Ignácio M. Os esponsais no direito luso-brasileiro. São Paulo: Quartier Latin, 2003. p. 132. ${ }^{262}$ Poveda Velasco, Ignácio M. Os esponsais no direito luso-brasileiro. São Paulo: Quartier Latin, 2003. p. 133.

${ }^{263}$ Nas palavras do autor: "A transmissão do immovel se opera por simples effeito do contrato, independente de tradição e de transcripção". Projecto do Codigo Civil Brazileiro e Commentario. Rio de Janeiro: Laemmert \& C, 1887. p. 288/Tomo V.
} 
“Art. 2672. - No caso de mais de uma transmissão sucessiva, o ultimo adquirente deve transcrever as anteriores, sujeitas á transcripção, e que não estejam transcriptas". ${ }^{264}$

Assim, o autor mantinha em seu projeto de Código Civil, praticamente o mesmo sistema de transmissão da propriedade imóvel da Lei Hipotecária de 1864, repetindo com pequenas alterações o seu art. $8^{\circ}$.

"Art. $8^{\circ}$. A transmissão entrevivos por titulo oneroso ou gratuito dos bens susceptiveis de hyphotecas assim como a instituição dos ônus reaes não operão seus effeitos a respeito de terceiro, senão pela transcripção e desde a data della."

Felício do SAntos justificou a exclusão dos termos "por titulo oneroso e gratuito", afirmando que eram desnecessários, já que toda transmissão ou era por um ou outro, não havendo maneira diversa. Já quanto à substituição de "transmissão de bens suscetíveis de hipoteca" por "transmissão entre vivos da propriedade immovel", o autor foi mais crítico, uma vez que entendia que a transcrição não tinha como função apenas garantir direitos de terceiros em relação ao crédito hipotecário, mas também assegurar posteriores transmissões. Assim, como o objetivo da transcrição era mais amplo, se houvesse algum imóvel que a lei declarasse não suscetível de hipoteca, também seria exigida a transcrição para que sua transmissão surtisse efeitos perante terceiros. ${ }^{265}$

O projeto inovou, ao exigir que o último adquirente de uma transmissão sucessiva transcrevesse todas as modificações jurídicas anteriores (art. 2672). A previsão era importante na medida em que possibilitava a formação de uma cadeia de atos registrados, possibilitando um maior conhecimento do histórico do imóvel.

Abandonado o projeto de Felício dos Santos, em 1890, o Governo Provisório contratou AnTÔNIo CốLho RodRigues ${ }^{266}$ para realizar a tarefa. Passados três anos, o jurista

\footnotetext{
${ }^{264}$ Brasil. Câmara dos Deputados. Projecto do Código Civil Brazileiro do Dr. Joaquim Felício dos Santos. Organizado pelo Conselheiro José Thomaz Nabuco de Araújo. Rio de Janeiro: Typographia Nacional, 1882. p. 121.

${ }^{265}$ Projecto do Codigo Civil Brazileiro e Commentario. Rio de Janeiro: Laemmert \& C, 1887. p. 278 e 279/Tomo V.

${ }^{266}$ Projecto do Codigo Civil Brazileiro. Rio de Janeiro: Imprensa Nacional, 1893. p. 169 e 170.
} 
entregou o projeto para a análise da Comissão nomeada. ${ }^{267} \mathrm{~A}$ obra, quanto à transmissão de bens imóveis, dispunha:

Título III. Capitulo I.

Secção I. “Art. 1381. A propriedade immovel transmitte-se:

$\S 1^{\circ}$. Entre vivos, pela transcripção do acto ou contrato habil para transferil-a na conformidade deste codigo, assim como por alluvião, accessão, ou prescripção.

$\S 2^{\circ}$. Depois da morte do titular, pelo direito hereditário dos seus successores legítimos ou testamentarios. (...)

Art. 1383. Entre os actos habeis para transferir a propriedade immovel comprehendem-se as sentenças de partilha, de homologação, de adjudicação e de expropriação.

Art. 1384. Entre os mesmos actos tambem se comprehendem os endossos dos títulos representativos da propriedade cadastrada, logo que sejam registrados no talão correspondente.

Art. 1385. O levantamento do cadastro, a fôrma dos respectivos títulos, a sua circulação, assim como o estabelecimento e a prova das servidões ou ônus reaes das propriedades incluídas nelle, serão reguladas por lei especial.

Secção II. Art. 1387. Para que a propriedade immovel se transmitta pela transcripção do respectivo acto jurídico requer-se:

$\S 1^{\circ}$. Que o transmittente seja o proprio dono do immovel, segundo o respectivo registro, ou esteja autorizado a dispor delle.

$\S 2^{\circ}$ Que goze do pleno exercício de sua capacidade civil.

$\S 3^{\circ}$ Que a transmissão repouse em um acto habil para operal-a.

$\S 4^{\circ}$ Que o instrumento desse acto seja transcripto no respectivo registro."

Perceba como o projeto de Código Civil de CoÊLHo Rodrigues é inovador ao incluir entre os atos que dependem de transcrição para transferirem direitos reais, as sentenças de

\footnotetext{
${ }^{267}$ Segundo Poveda Velasco, o projeto de Coêlho Rodrigues sofreu grande influência das doutrinas alemãs da época. Os esponsais no direito luso-brasileiro. São Paulo: Quartier Latin, 2003. p. 136. Talvez seja este o motivo do projeto ter se desprendido da tradição lusitana e inovado em aspectos referentes à transmissão da propriedade imóvel.
} 
partilha, homologação, adjudicação e expropriação (§ $1^{\circ}$ do art. 1381 c/c art. 1383). Ao ampliar o rol dos atos registráveis, o autor permite a existência de um assento imobiliário que com maior exatidão reflita a situação jurídica do imóvel. Ademais, ao exigir no $\S 1^{\circ}$ do art. 1387 que apenas o dono inscrito no registro transfira o bem imóvel, prevê requisito indispensável para a adoção do princípio da continuidade, que, infelizmente, foi introduzido no sistema registral brasileiro apenas em 1928.

Outra novidade foi a previsão de transferência da propriedade cadastrada por mero endosso do seu título representativo, o que proporcionaria maior mobilidade aos bens imóveis, estimulando as transmissões e, conseqüentemente, a economia (art. 1384). A idéia não era nova no ordenamento brasileiro, já que o mesmo era possível com os imóveis sujeitos ao Registro Torrens, porém a previsão de CoÊLHo RodRIGUES mostrou-se extremamente audaciosa por permitir a mobilidade aos imóveis submetidos ao registro comum, sistema ainda no Brasil tão confuso e deficitário.

Apesar das inovações e ousadias, o projeto de CoÊLHo RodRIGUES recebeu parecer contrário da Comissão. O Senado, tentando aproveitá-lo, propôs que o Governo chamasse jurisconsultos para revê-lo, sugestão que não foi acatada pela Câmara, caindo a questão no esquecimento.

Em 1899, seis anos após o último fracasso legislativo, Clóvis Bevilaqua assumiu a tarefa de elaborar um Código Civil.

Como assevera Pontes de Miranda, há entre os projetos apresentados entre 1865 e 1899 uma "solidariedade histórica" tendo cada qual servido de inspiração para o posterior e influenciado artigos do Código Civil de $1916 .{ }^{268}$ Com efeito, a afirmação confirma-se quando se verifica que o próprio BEVILAQUA, em 1906, declarou que para a elaboração do projeto tinha

${ }^{268}$ Fontes e evolução do Direito Civil Brasileiro. Rio de Janeiro: Pimenta de Mello \& C., 1928. p. 103. Referindo-se às fontes materiais do Código Civil de 1916, o autor afirmava: “(...) se as innovações em relação ao direito anterior, foram 1.178, aos códigos estrangeiros pediu-se menos de metade destas, pois foram de elaboração brasileira mais de 670. Concorrem para isto: Esboço de Teixeira de Freitas, 189, Projecto de Felício dos Santos, 49, de Coelho Rodrigues, 154, de Bevilaqua, 135, revisto, 78, da Camara dos Deputados, 40, Senado Federal, 26, e outro, 2 ou 1". Fontes e evolução do Direito Civil Brasileiro. Rio de Janeiro: Pimenta de Mello \& C., 1928. p. 119 e 120. 
se utilizado de elementos obtidos no Esboço de Teixeira de Freitas e, principalmente, no trabalho de CoÊLho Rodrigues. ${ }^{269}$

Quando o presidente Campos Sales convocou Clóvis Bevilaqua para elaborar o Código Civil, o Brasil passava por uma época de contradições. De um lado, a crise na economia, em decorrência da depressão econômica mundial; de outro, sinais de uma nova mentalidade, com uma vida intelectual crescente no país. Dessa forma, a pressão para a elaboração do Código Civil foi surgindo na classe intelectual do país. ${ }^{270}$

Como já foi visto, esse grupo intelectualizado do país compunha a classe média, que era estritamente ligada ao setor agrário-exportador e pouco propensa a mudanças. Assim, a classe intelectualizada sentia-se encurralada; de um lado, discutiam doutrinas e desejavam aplicá-las; de outro, tinham receio de que uma codificação civil, regulando a vida privada, pudesse trazer como conseqüência uma alteração em seu status quo. Dessa maneira, o grupo tentou ao máximo postergar a promulgação de um Código Civil e, quando não foi mais possível fazê-lo, passaram a defender o surgimento de um que mantivesse as tradições.

Mas esse desinteresse pela codificação civil, não atingia Campos Sales. O presidente queria que todo o processo de elaboração e aprovação do Código Civil acontecesse em um quadriênio, ou seja, a criação, revisão por um conselho de jurisperitos, discussão e votação nas duas Casas legislativas deveriam acontecer entre os anos de 1899 e 1902 . O pequeno prazo para a elaboração do Código advinha do receio de que mais uma vez os trabalhos fossem sendo prolongados e a codificação da matéria civil não ocorresse. ${ }^{271}$

Segundo SAN Tiago Dantas, a rapidez com que o Governo queria que transcorresse o processo de elaboração e aprovação do Código Civil justificava a escolha de Clóvis Bevilaqua como projetista, entre tantos nomes de maior prestígio (como Lafayette,

${ }^{269}$ Bevilaqua completava a enumeração das fontes da qual se utilizou para a elaboração do projeto dizendo: "Além desses materiaes, aos quaes eu intencionalmente queria ligar o meu trabalho, é natural que pedisse á jurisprudencia pátria as peculiaridades aproveitaveis de sua feição, á doutrina e á legislação comparada, os seus inestimaveis ensinamentos". Em Defeza do projecto de Código Civil Brazileiro. Rio de Janeiro: Francisco Alves, 1906. p. 26.

${ }^{270}$ Dantas, San Thiago prefácio em Rui Barbosa. Obras Completas de Rui Barbosa. Parecer Jurídico. Rio de Janeiro: Oficina Gráfica do Departamento de Imprensa Nacional, 1968. p. XXIII/ vol. XXXII, Tomo III

${ }^{271}$ Dantas, San Thiago prefácio em Rui Barbosa. Obras Completas de Rui Barbosa. Parecer Jurídico. Rio de Janeiro: Oficina Gráfica do Departamento de Imprensa Nacional, 1968. p. XIII e XVI/ vol. XXXII, Tomo III 
Coêlho Rodrigues, Carlos de Carvalho e outros). Era interessante escolher alguém que não tivesse uma enorme bagagem jurídica e, em decorrência, um nome a zelar. ${ }^{272}$ Escolhendo, por exemplo, LAFAYETTE, provavelmente, os trabalhos não se concluiriam em 4 anos, já que este buscaria a perfeição. Escolhendo Bevilaqua, professor no Recife, ter-se-ia alguém que fundaria no projeto o seu renome, ou seja, não precisaria elaborar um a altura de uma carreira de prestígios. ${ }^{273}$

Convidado em janeiro de 1899 para a feitura do Código Civil, Bevilaqua entregou o projeto em outubro do mesmo ano, dando início aos trâmites legislativos. RuY BarbosA criticava a atitude do Governo de desejar iniciar e concluir os trabalhos em um prazo de 4 anos, queria que o Código fosse puro e duradouro, testemunha da geração que o elaborou. Ademais, discordava da escolha do projetista, acreditava que Bevilaqua não tinha a maturidade jurídica necessária para tal empreendimento. ${ }^{274}$

Entregue o projeto em outubro de 1899, ele chegou à Comissão Revisora em março de 1900. Em novembro do mesmo ano, o projeto já estava revisto, sendo encaminhado ao Legislativo. Após 15 dias, uma breve mensagem o introduziu na Câmara dos Deputados. O ano de 1901 terminou sem que o projeto fosse aprovado. A Comissão Especial da Câmara dos Deputados apresentou, em janeiro de 1902, um novo projeto para ser votado no plenário chamado de "Projeto da Câmara". 275

\footnotetext{
${ }^{272}$ Epitácio Pessoa, Ministro da Justiça no governo de Campos Sales, justifica a escolha de Clóvis Bevilaqua para a elaboração do Código Civil de outra maneira: "O Dr. Clóvis Bevilaqua estava como que naturalmente indicado para a grandiosa empresa, não só como um dos nossos mais profundos jurisconsultos, mas também por já haver desenvolvido em eminentes obras de doutrina - "Direito da Família", "Direito das Obrigações", "Direito das Sucessões" - quase todo o Direito Civil". In: Segurado, Milton Duarte. O Direito no Brasil. São Paulo: José Bushatsky, 1972. p. 392 e 393.

${ }^{273}$ Obras Completas de Rui Barbosa. Parecer Jurídico. Rio de Janeiro: Oficina Gráfica do Departamento de Imprensa Nacional, 1968. p. XIII/vol.XXXII, Tomo III.

${ }^{274}$ Referindo-se a Bevilaqua, Rui Barbosa escreveu no jornal "A Imprensa": "Aqui está porque, ao nosso ver, a sua escolha para codificar as nossas leis civis foi um rasgo do coração, não da cabeça. Com todas as suas prendas de jurisconsulto, lente e expositor, não reúne todos os atributos, entretanto para essa missão entre todas melindrosa. Falta-lhe a consagração dos anos. Falta-lhe a evidência da autoridade. Falta-lhe um requisito primário, essencial, soberano para tais obras: a ciência da sua língua, a vernaculidade, a casta correção do escrever". Dantas, San Thiago prefácio em Ru Barbosa. Obras Completas de Rui Barbosa. Parecer Jurídico. Rio de Janeiro: Oficina Gráfica do Departamento de Imprensa Nacional, 1968. p. XVIII/ vol. XXXII, Tomo III.

${ }^{275}$ Dantas, San Thiago prefácio em Rui Barbosa. Obras Completas de Rui Barbosa. Parecer Jurídico. Rio de Janeiro: Oficina Gráfica do Departamento de Imprensa Nacional, 1968. p. XIX/ vol. XXXII, Tomo III.
} 
Assim, terminava o quadriênio previsto sem que o Código Civil tivesse sido promulgado. Ainda era necessário que o projeto fosse aprovado no Senado e retornasse à Câmara, caso sofresse alguma emenda. A urgência na aprovação levou o Governo a convocar o Congresso nas férias (de 25 de fevereiro a 3 de maio). Ainda em 1902, constituiu-se a Comissão Especial do Senado, presidida por RuY BARBOSA, para receber o "Projeto da Câmara".

Com todas as medidas tomadas, sessões extraordinárias e normas regimentais especiais para acelerar as votações, acreditava-se que a tarefa seria cumprida ainda no Governo de Campos Sales. No entanto, não foi o que aconteceu, a tarefa teve que ser transferida ao novo Governo. ${ }^{276}$

Como o novo Governo não via tanta urgência na codificação civil, a tramitação do projeto tornou-se mais lenta. Dessa maneira, foi apenas em 1912 que o Senado concluiu sua análise, enviando o projeto, com várias emendas, à Câmara dos Deputados, sendo a maioria delas referentes à redação e 186 alterações quanto à essência da matéria regulada. ${ }^{277}$

Chegando o projeto emendado à Câmara dos Deputados, foi nomeada uma Comissão para estudar as modificações. Em 1915, a Câmara aprovou a maioria das emendas apresentadas pelo Senado, rejeitando apenas 94. Das emendas recusadas pelos deputados, 24 foram mantidas pelo Senado, com o retorno do projeto à sua Casa, e dessas, 9 foram novamente recusadas pela Câmara. Por fim, as Comissões do Senado e da Câmara dos Deputados reuniram-se para a redação definitiva do projeto, que foi aprovado em 1915, sancionado e promulgado em $1^{\circ}$ de janeiro de 1916 como o decreto n. 3.071, que passou a vigorar em $1^{\text {o }}$ de janeiro de $1917 . .^{278}$

Na elaboração de seu projeto, BEVILAQUA recorreu algumas vezes à legislação estrangeira, o que não era novidade. Em geral, os projetos apresentados para a elaboração do Código Civil não se restringiram às tradições jurídicas brasileiras, buscando inspiração em institutos europeus (ainda que as diferenças entre a Europa e o Brasil fossem evidentes). Essa postura ampliou a introdução de construções jurídicas alienígenas nas discussões doutrinárias

${ }^{276}$ Ibidem., p. XX e XXIV.

${ }^{277}$ Segurado, Milton Duarte. O Direito no Brasil. São Paulo: José Bushatsky, 1972. p. 394.

${ }^{278}$ Ibidem., mesma página. 
e legislativas, incrementando-as e permitindo alguns avanços no direito de uma sociedade ainda patriarcal. ${ }^{279}$

Essa procura por soluções e inovações na cultura jurídica européia não foi diferente no relativo à transmissão da propriedade imóvel. A economia e os meios jurídicos esperavam que a legislação que surgisse para regular as relações civis trouxesse um sistema registrário completo, que pudesse garantir a segurança do crédito, do direito de propriedade e do comércio. A solução parecia estar na adoção de um dos dois sistemas registrários existentes na Europa, o francês ou o germânico.

No entanto, é importante ressaltar que essa procura por modelos registrários estrangeiros não ocorreu pela primeira vez com a elaboração do Código Civil. Alguns juristas e parlamentares já haviam questionado a adoção do sistema francês ou alemão de transmissão de propriedade imóvel no Brasil, no momento em que se discutia o projeto que culminou na Lei Hipotecária de 1864. Naquela época, como já visto no capítulo anterior, a Comissão do Senado acabou adotando o artigo $8^{\circ}$ em acordo com a legislação francesa, dispondo que o simples acordo entre as partes já transferia o domínio, restando à transcrição a única função de tornar a transação conhecida de terceiros. Sabe-se que com o tempo, esse entendimento foi afastado, e a transcrição passou a não só tornar pública a transferência, como também constituir direito.

Com tantos projetos de Código Civil sendo apresentados e com a ânsia por segurança nas modificações jurídico reais, as discussões acerca da adoção do sistema francês ou alemão tornaram-se ainda mais presentes e intensas. Mas antes de se analisar os debates sobre a matéria, torna-se esclarecedora uma rápida abordagem sobre as características de cada sistema.

A grande diferença entre os dois modelos consiste na publicidade que cada um oferece às transmissões reais. ${ }^{280}$

\footnotetext{
${ }^{279}$ Gomes, Orlando. Raízes históricas e sociológicas do Código Civil Brasileiro. São Paulo: Martins Fontes, 2003. p. 19 e 20.

${ }^{280}$ A divergência é tamanha que AfrÂnio de CARvalho chegou a dividir os sistema registrários em sistema de publicidade. Segundo o autor, existem três sistemas de publicidade: consensual ou privatista, publicista e eclético. No primeiro, a propriedade se transfere pelo título, pelo acordo de vontades, e a publicidade apenas informa os terceiros sobre o ato (França). No segundo, a publicidade é elemento essencial à transferência da propriedade,
} 
Na França, o Código Civil Napoleônico de 1804, trouxe uma grande inovação ao prever que a transferência da propriedade imóvel ocorria por meio do simples consentimento das partes, sem qualquer ato exterior que proporcionasse certa notoriedade às mutações.

\section{O art. 711 do Código francês dispunha: ${ }^{281}$}

"A propriedade dos bens se adquire e se transmite... por efeito das obrigações"

\section{Adiante, no art. 1.138 a lei confirmava que a transmissão era perfeita com o} simples consentimento das partes:

"A obrigação de entregar a coisa é perfeita pelo simples consentimento das partes contratantes.

Torna ela o credor proprietário e deixa a coisa a seu risco desde o momento em que devia ela ser entregue, ainda que a tradição não tenha sido feita...”

Mais claro ainda era o dispositivo 1.583 que tratando sobre o contrato de compra e venda, previa:

"É ela perfeita entre as partes, e a propriedade é adquirida de pleno direito pelo comprador, ante o vendedor, desde que haja acordo sobre a coisa e o preço, embora a coisa não tenha sido ainda entregue nem o preço ainda pago". ${ }^{282}$

constituindo o direito (Alemanha). No último, há a combinação do título com o modo de adquirir. É com a publicidade que se constitui direito e ele se torna oponível a terceiros (Brasil). Registro de Imóveis. $3^{\mathrm{a}}$ ed., Rio de Janeiro: Forense, 1982. p. 18.

${ }^{281}$ Todos os artigos foram obtidos da tradução realizada por Souza Diniz. Souza Dinız. Código Napoleão ou Código Civil dos Franceses. Rio de Janeiro: Distribuidora Record, 1962.

${ }^{282}$ No texto original: Art. 711. "La propriété des biens s'acquiert est se transmet par sucession, par donation entre vifs ou testamentaire, et par l'effet dês obligations".

Art. 1.138. L'obligation de livrer la chose est parfaite par seul consentement des parties contractantes.

Elle rend le créancier propriétaire et met la chose à sés risques dès línstant où elle a dû être livrée, encore que la tradition n'en ait point éte faite..."

"Art. 1.583. Elle est parfaite entre les parties, et la proprieté est acquise de droit à l'acheteur à l'éguard du vedeur, dès qu'on est convenu de la chose et du prix, quoique la chose n'ait pás encore éte livrée ni lê prix payé". JАCOB, François et al. Code Civil, 101 éd. Paris: Dalloz, 2002. Recorda-se que até hoje estes artigos referentes a transmissão da propriedade estão vigentes. 
Assim, como a transmissão da propriedade imóvel ocorria com o consentimento entre as partes, não sendo nem mesmo preciso a tradição (e esta por questões históricas era realizada por meio da inclusão no contrato de uma cláusula de estilo). ${ }^{283}$

Segundo Teixeira de Freitas, houve a confusão do direito real e pessoal, tomandose a propriedade em seu elemento individual e não social. $\mathrm{O}$ autor afirmava que os franceses passaram a contar com a boa fé das pessoas, como se a má-fé não fosse possível ou não os atingissem. ${ }^{284}$ Para SÁ Pereira, se por um lado, o princípio da transferência convencional do domínio simplificou o modo de aquisição de propriedade imóvel, por outro, trouxe muita insegurança a terceiros. ${ }^{285}$

Almeida Prado era do mesmo entendimento. Segundo o autor, se o contrato garantia de certa forma as relações entre alienante e adquirente, o mesmo não acontecia com terceiros (credores ou segundos adquirentes). Estes continuavam desconhecendo o negócio jurídico, já que a busca em cartórios de notas além de demorada e cara, não era totalmente garantida. Afinal, o alienante de má-fé poderia, com facilidade, fraudar a transmissão, lavrando a escritura pública em cartório de circunscrição diversa daquela em que se situava o imóvel, o que dificultaria ainda mais a pesquisa. Ainda, nos casos em que a escritura pública não fosse exigida, bastando o instrumento particular, a situação ficava mais drástica, não havendo qualquer publicidade. ${ }^{286}$

A inovação do Código Civil Napoleônico foi tão inesperada e tão contrária à boa razão que, por algum tempo, questionou-se se ela tinha mesmo revogado a Lei de 11 de Brumário do ano Sétimo. Troplong, Martou e outros jurisconsultos afirmavam que a medida

\footnotetext{
${ }^{283}$ Almeida Prado analisando o histórico da transferência de bens na França escreve: "Consagrou-se, na França, a cláusula denominada desaisine-saisine ou tradition feinte que equivalia a constituto possessorio. Na Itália e também na França, entrou em uso a instrumentalis traditio, por efeito da qual não foi mais necessário ir propriamente ao lugar para se obter a entrega bilateral, mas bastou que, no instrumento de alienação se inserisse uma formula, pela qual o vendedor, o doador, o permutante declaravam tomá-la por tradição. E visto que essas clausulas se costumavam inserir em todos os contratos de alienação, tornaram-se verdadeiras e proprias clausulas de estilo, confundindo-se, pois, a tradição no próprio ato contratual". Transmissão da propriedade imóvel. São Paulo: Saraiva \& Comp.Editores, 1934. p. 114.

${ }^{284}$ Consolidação das Leis Civis. Rio de Janeiro: Typographia Universal de Laemmert, 1865. p. CLVI.

${ }^{285}$ Direito das Cousas. Art. 524-678. In: Lacerda, Paulo de. Manual do Código Civil Brasileiro. Rio de Janeiro: Jacintho Ribeiro dos Santos, 1924. p. 101/vol.VIII.

${ }^{286}$ Para o autor estes mesmos problemas eram verificados no Brasil quando a transmissão do imóvel ocorria pela inclusão da cláusula constituti no contrato. Transmissão da propriedade imóvel. São Paulo: Saraiva \& Comp.Editores, 1934. p. 116.
} 
tinha sido introduzida sorrateiramente no Código, sem as discussões que exigia. De qualquer forma, quanto aos móveis, o princípio não chegou a ser adotado e quanto aos imóveis, foi aplicado com algumas restrições. ${ }^{287}$

O receio de que o novo sistema trouxesse inúmeros conflitos e incertezas levou os jurisconsultos franceses a pleitearem uma reforma. Essa veio com a Lei de 23 de março de 1855, que fez reviver o regime hipotecário da Lei de 11 de Brumário com algumas alterações. ${ }^{288}$ A nova Lei exigiu a transcrição do ato translativo de propriedade imóvel no registro do conservador de hipotecas. ${ }^{289}$

\section{$\mathrm{O}$ artigo $1^{\circ}$ da lei dispunha: $:^{290}$}

"São transcritos no registro das hipotecas da situação dos bens:

$1^{\text {o }}$ Todo ato entre vivos, translativo de propriedade imobiliária ou de direitos reais suscetíveis de hypotheca.".

Adiante, no artigo $3^{\circ}$ determinava:

"Até a transcrição, os direitos resultantes dos atos e julgamentos enunciados nos artigos precedentes não podem ser opostos aos terceiros que têm direitos sobre o imóvel e que os conservaram de conformidade com as leis".

Perceba que as alterações trazidas pela Lei de 1855 não transformaram a essência da disposição do Código Francês, uma vez que a transferência da propriedade imóvel continuou ocorrendo entre as partes com a simples convenção. ${ }^{291}$

A transcrição do título em livros registrários era facultativa, servindo unicamente como meio de publicidade. Como não era necessária para que houvesse a transferência, poderia parecer, à primeira vista, que a transcrição não apresentava efeitos práticos. Contudo,

287 Teixeira de Freitas, Augusto. Consolidação das Leis Civis. Rio de Janeiro: Typographia Universal de Laemmert, 1865. p. CLVIII e CLIX.

${ }^{288}$ Ibidem., p. CLX.

${ }^{289}$ Sá Pereira, Virgilio de. Direito das Cousas. Art. 524-678. In: Lacerda, Paulo de. Manual do Código Civil Brasileiro. Rio de Janeiro: Jacintho Ribeiro dos Santos, 1924. p. 101/vol.VIII.

${ }^{290}$ Os artigos foram obtidos na obra de Paulo de Lacerda. Manual do Código Civil Brasileiro. Rio de Janeiro: Jacintho Ribeiro dos Santos, 1924. p. 101.

${ }^{291}$ Sá Pereira, Virgilio de. Direito das Cousas. Art. 524-678. In: Lacerda, Paulo de. Manual do Código Civil Brasileiro. Rio de Janeiro: Jacintho Ribeiro dos Santos, 1924. p. 102/vol.VIII 
isso não era verdade, já que antes da transcrição, aqueles titulares de direitos sobre o imóvel, que se tinham submetido ao registro, podiam alegar que desconheciam a mutação real. ${ }^{292}$ Apenas depois da transcrição, era que o ato passava a ser presumidamente conhecido por todos.

Já no relativo à alienação, a transcrição era importante na medida em que garantia preferência àquele que primeiro a transcrevesse (ou seja, livrava este primeiro adquirente de qualquer reclamação). ${ }^{293}$

Assim, pode-se afirmar que antes da transcrição do título de transferência, a alienação tinha efeito entre as partes e em relação a terceiros que fossem estranhos ao imóvel. ${ }^{294}$ Esta assertiva tem as seguintes conseqüências: primeiro, esses terceiros podiam adquirir direitos reais do proprietário não transcrito e a ausência de transcrição não poderia ser questionada por aquele que não tivesse direito algum sobre o bem, ou tivesse direito de força inferior, ou tendo o direito, não o houvesse conservado por meio da transcrição ${ }^{295}$; segundo, antes da transcrição, o adquirente podia reivindicar o domínio desses terceiros, já que eles não tinham direitos reais sobre o imóvel, conservados pela lei. ${ }^{296}$

A publicidade ocorrida por meio da transcrição era apenas o meio pelo qual se informava a terceiros sobre a existência de um ato jurídico, opondo-o a todos aqueles que pretendessem direitos sobre o imóvel. Dessa maneira, a transcrição com o efeito de mera publicidade, não afirmava nada sobre a validade do negócio, não corrigia os vícios do título, nem garantia o adquirente de possíveis evicções. ${ }^{297}$

\footnotetext{
${ }^{292}$ BuEno, Fernando Euler. Effeitos da transcripção no regime do Código Civil Brasileiro. São Paulo: Revista dos Tribunais, 1941. p.13.

${ }^{293}$ Montes, Angel Cristóbal. Direito Imobiliário Registral. Tradução de Francisco Tost. Porto Alegre: Sergio Antonio Fabris Editor, 2005. p. 219.

${ }^{294}$ LAFAYETTE imaginava a seguinte situação: como no direito francês a transferência da propriedade ocorria para credores quirografários sem a transcrição, já que eles não tinham direito real sobre o imóvel, podia ocorrer que no momento do pagamento, o bem não mais respondesse pela dívida do devedor já que este sem o conhecimento do credor tinha alienado o bem, não sendo mais seu proprietário. Direito das Cousas. Rio de Janeiro: B. L. GarnierLivreiro-Editor, 1877. p. 134/vol.I.

${ }^{295}$ GARCIA, Lysippo. O Registro de Imóvei: a transcrição. Rio de Janeiro: Francisco Alves, 1922. p. 54/vol.1.

${ }^{296}$ Pereira, Lafayette Rodrigues. Direito das Cousas. Rio de Janeiro: B. L. Garnier-Livreiro-Editor, 1877. p. 134/ vol.I.

${ }^{297}$ Garcia, Lysippo. O Registro de Imóvei: a transcrição. Rio de Janeiro: Francisco Alves, 1922. p. 53 e 54/vol.1.
} 
Como para Almeida Prado o ato translativo ou constitutivo de direitos reais era "revogavel, recindivel, anulavel e resolúvel" mesmo em relação a terceiros de boa-fé, o autor afirmava que no sistema francês havia absoluta preponderância da causa. ${ }^{298}$

De fato, no modelo francês, a transferência da propriedade imóvel sempre acompanha a situação da obrigação que lhe serve de causa, ou seja, se o contrato for nulo, a transmissão também será nula. A justificativa decorre do entendimento de que ninguém pode transmitir mais direito do que possui; logo, se o direito transferido possui vícios, estes atingem o domínio do adquirente. Da mesma forma, se não houver direito para se transmitir, já que o alienante não era o real proprietário do bem, o adquirente não se torna seu titular. ${ }^{299}$

Parece que as imprecisões do sistema francês não incomodavam apenas juristas estrangeiros. Segundo Lysippo GARCIA, uma Comissão extraparlamentar foi nomeada em 30 de maio de 1891, por iniciativa do Ministro das finanças, RouviER, para analisar a pertinência da adoção na legislação francesa dos livros prediais do sistema germânico, adaptando o cadastro a fins jurídicos e físcais. Apesar das vantagens de um cadastro da propriedade imóvel, a Comissão concluiu que como seriam inúmeras as dificuldades para a implantação desses livros na França, melhor seria manter o regime registrário como estava. ${ }^{300}$

A preocupação na implementação dos livros decorria do fato de que no sistema registral francês estes não traziam a descrição e identificação do imóvel, apenas sendo organizados de acordo com o nome das partes envolvidas nos atos jurídicos, o que prejudicava ainda mais a publicidade do registro. Quando se desejasse descobrir a situação jurídica de determinado imóvel, a busca deveria ser feita utilizando-se o nome dos proprietários. Qualquer falha na cadeia, seja devido a ausência ou erro no nome do titular do domínio, dificultava a busca, tornando ainda mais difícil descobrir a situação do bem. ${ }^{301}$

\footnotetext{
${ }^{298} \mathrm{O}$ autor entendia que o direito francês era extremamente individualista ao se preocupar mais em respeitar os direitos do alienante do que os de terceiros. Transmissão da propriedade imóvel. São Paulo: Saraiva \& Comp.Editores, 1934. p. 121 e 124.

299 Prado, Francisco Bertino de Almeida. Transmissão da propriedade imóvel. São Paulo: Saraiva \& Comp.Editores, 1934. p. 124 e 125.

${ }^{300}$ O Registro de Imóvei: a transcrição. Rio de Janeiro: Francisco Alves, 1922, p. 111/vol.1.

${ }^{301}$ Azevedo, Philadelpho. Registro de Imóveis (Valor da Transcrição). Rio de Janeiro: Jacintho Editora, 1942. p. 28.
} 
Dessa maneira, o sistema registrário francês parece não atender os anseios de segurança do crédito e do comércio, garantindo apenas aos verdadeiros titulares seus direitos sobre o bem (segurança da propriedade).

Esse sistema de aquisição da propriedade imóvel não agradava muitos doutrinadores brasileiros, ${ }^{302}$ porém, como já foi visto, era o melhor sistema para FeLício dos SAntos que escolheu adotá-lo no projeto de Código Civil apresentado ao Governo em 1881.

Analisado rapidamente o sistema francês, passa-se agora para o estudo do sistema germênico (ou alemão).

Antes da promulgação em 18 de agosto de 1896, por Guilherme II, do Código Civil Alemão (que passou a ter eficácia a partir de $1^{\circ}$ de janeiro de 1900), vários sistemas imobiliários estavam concomitantemente em vigor, variando de um para outro Estado da confederação ou mesmo dentro de um mesmo Estado. ${ }^{303}$ O Código Civil Alemão, influenciado pelo direito prussiano, substituiu essa diversidade de regras por um sistema registral uniforme, sem contudo ignorar os direitos existentes nos territórios. ${ }^{304}$

O direito imobiliário germânico é composto de duas partes: uma jurídico-formal e outra jurídico-material. ${ }^{305}$ A primeira compreende os princípios fundamentais sobre a realização e o processo dos registros. A segunda está prevista nos artigos 873 a 912 do Código Civil Alemão e regula os pressupostos para o registro das relações jurídico-reais. ${ }^{306}$

Os requisitos materiais são mais importantes que os jurídico-formais, o que significa dizer que uma modificação jurídico-real será válida mesmo que, presentes os

\footnotetext{
302 TeiXeira de Freitas agradecia o fato do direito brasileiro em um momento de consolidação de suas leis civis, não precisar lutar com os obstáculos e incoerências de um sistema como o francês. Consolidação das Leis Civis. Rio de Janeiro: Typographia Universal de Laemmert, 1865. p. CLXIII.

${ }^{303}$ BuEno, Fernando Euler. Effeitos da transcripção no regime do Código Civil Brasileiro. São Paulo: Revista dos Tribunais, 1941. p. 15.

${ }^{304} \mathrm{~J}_{\mathrm{ARDIM}}$ Mônica. O sistema registral germânico. Revista de Direito Imobiliário, São Paulo, n. 59, ano 28, p. 214 e $215,2005$.

${ }^{305}$ As disposições formais e materiais do sistema alemão estão separadas. As primeiras estão em uma Ordenança de Registro Imobiliário, e as segundas no Código Civil. Carvalho, Afrânio. Registro de Imóveis. $3^{\mathrm{a}}$ ed., Rio de Janeiro: Forense, 1982. p. 20.

${ }^{306}$ Soriano de souza Neto, José. Publicidade Material do Registro Imobiliário: efeitos da transcrição. Recife: [s.n.], 1940. p. 57.
} 
primeiros, a inscrição não siga as exigências formais. ${ }^{307}$ Segundo Soriano Neto, apesar da diferença entre as duas partes do direito imobiliário, ambos estão intimamente ligados em uma relação de causalidade, "o material assenta, fundamentalmente, no formal, que o explica e justifica". 308

O autor afirmava que era por meio dessa ligação "orgânica" entre o direito formal e o direito material alemão, que era possível conciliar os dois maiores objetivos do sistema registral: a segurança jurídica (que para SoRIANo Neto correspondia à segurança do direito da propriedade) e a segurança do comércio. ${ }^{309}$

Dessa maneira, como estão diretamente relacionados, uma legislação que desejasse aplicar o sistema germânico deveria preocupar-se em reproduzir não só o direito material, como também o direito formal.

O sistema alemão é caracterizado pela presença em livros registrários de todos os imóveis e de todas as informações a eles referentes. É adotado o princípio da folha, ou seja, as inscrições relativas a uma determinada propriedade devem constar em uma mesma folha do livro, em ordem consecutiva e sem ser interrompida pela inscrição de outro imóvel, o que significa dizer que cada propriedade tem sua própria folha. Assim, todas as inscrições relativas ao imóvel estão reunidas em um mesmo lugar, o que facilita as buscas. ${ }^{310}$

Os dados descritivos do imóvel, que constam em sua folha, são obtidos no cadastro do bem, formado com base em informações oficiais. Todo imóvel no sistema germânico tem seu próprio cadastro, que o individualiza diante dos demais. ${ }^{311}$

\footnotetext{
${ }^{307}$ Ibidem., p. 58.

${ }^{308}$ Ibidem., mesma página.

${ }^{309}$ Publicidade Material do Registro Imobiliário: efeitos da transcrição. Recife: [s.n.], 1940. p. 60.

${ }^{310}$ MôNICA JARDIM ensina que a ficha ou folha é composta por quatro partes: o índex, no qual é feita a descrição do imóvel de acordo com as informações do cadastro, a secção I, no qual é inscrita a propriedade e seu fundamento jurídico, a secção II na qual constam as cargas e restrições ao direito de propriedade, exceto a hipoteca, e, por fim, a secção III na qual são inscritas além de dívidas e limitações sobre os direito de dispor, as hipotecas. $O$ sistema registral germânico. Revista de Direito Imobiliário, São Paulo, nº 59, ano 28, p. 217 e 218, 2005.

311 Para Lysippo GARCiA, o sistema germânico não dependia dos livros fundiários e os seus princípios não decorriam dele. Segundo o autor, se isso fosse verdade, em lugares em que a adoção do cadastro fosse quase impossível, a propriedade nunca seria consolidada, o que não era verdade. No entanto, ressalta-se que o autor reconhecia que um bom sistema imobiliário deveria ter registro (caráter jurídico) e cadastro (caráter administrativo) das propriedades bem organizados. O Registro de Imóveis: a transcrição. Rio de Janeiro: Francisco Alves, 1922. p. 128 e 135/vol.1.
} 
A transmissão do bem imóvel ocorre por meio da inscrição do negócio jurídico nos livros registrários, no entanto, essa inscrição não tem por fundamento um negócio jurídico causal, que cria obrigações entre as partes, mas sim um acordo real que se destina unicamente a efetuar a modificação da titularidade. ${ }^{312} \mathrm{Com}$ a inscrição no registro, surge a presunção relativa (juris tantum) de sua veracidade, que pode converter-se em presunção absoluta (juris et de jure) quando o ato envolver adquirentes de boa-fé, que tenham confiado nas informações existentes no registro. ${ }^{313}$

Em outras palavras, diferentemente do sistema francês, o acordo de vontades por meio do contrato não é suficiente para transmitir a propriedade ou constituir direitos reais; sua função é apenas criar obrigações entre as partes. Para que ocorra a transferência ou constituição é necessários um acordo real (AlmeIda PRADo também o chama de contrato de alienação) e sua inscrição no livro fundiário. O acordo real é realizado com o comparecimento conjunto de alienante e adquirente perante o oficial de registro e suas declarações de vontade quanto à modificação jurídico real. ${ }^{314} 315$

${ }^{312}$ O Código Civil do Império Alemão dispunha:

"Art. 873. Para alienar um imóvel ou gravá-lo de um direito real, assim como para gravar ou alienar um direito real imobiliário, é preciso o acordo de vontades do titular do direito e da outra parte, sobre a mutação a realizar, e a inscrição dessa mutação no livro fundiário, a menos que a lei imponha outra forma.

Antes da inscrição as partes não são ligadas pelo acordo senão se as suas declarações constam dum ato judicial ou notariado, ou se foram feitas no registro fundiário ou the foram apresentadas, ou se o titular do direito entregou a outra parte um consentimento para a inscrição, conforme as prescrições da lei sobre os livros fundiários." Dispositivo extraído da obra de Sá Pereira. Sá Pereira, Virgilio de. Direito das Cousas. Art. 524-678. In: LaCerda, Paulo de. Manual do Código Civil Brasileiro. Rio de Janeiro: Jacintho Ribeiro dos Santos, 1924, p. 114/ vol.VIII.

${ }^{313}$ JARDIM, Mônica. O sistema registral germânico. Revista de Direito Imobiliário, São Paulo, n. 59, ano 28, p. 215 e $216,2005$.

${ }^{314}$ Prado, Francisco Bertino de Almeida. Transmissão da propriedade imóvel. São Paulo: Saraiva \& Comp.Editores, 1934. p. 112. Como não há previsão nas normas da ABNT, optou-se por colocar quando necessário mais de uma nota de rodapé no final de um mesmo parágrafo.

${ }^{315}$ Interessante o entendimento de LACERDA DE ALMEIDA, para quem a transcrição do direito brasileiro não é uma tradição solene, diferentemente da inscrição alemã. Para o autor, como a tradição é um ato bilateral, um acordo entre alienante e adquirente, e no Brasil a transcrição pode ser feita por qualquer uma das partes e comumente é realizada pelo comprador, não há tradição propriamente dita. No sistema brasileiro a transcrição nada mais é do que a cópia do contrato de alienação que habilita o comprador a exigir a tradição, ou seja, a investir-se na posse, sendo assim, tradição e transcrição são atos distintos e a segunda não é suficiente para a transferência da propriedade imóvel. Almeida ainda afirmava que no direito alemão a inscrição no Registro Predial é verdadeiramente uma tradição, já que alienante e adquirente devem comparecer juntos no cartório de registro e declarar o ato de desapossamento voluntário por um e a aquisição por outro. Direito das Cousas. Rio de Janeiro: Jacintho Ribeiro dos Santos, 1908. p. 179, 180 e 185. Nesse mesmo sentido SÁ Pereira, que completava a idéia de AlmEIDA ao dizer que quando se considerava a transcrição do sistema brasileiro uma tradição solene, surgia um conflito com a noção científica da tradição, pois esta era um contrato bilateral, enquanto a transcrição era um ato unilateral. Direito das Cousas. Arts. 524-673. In: LACERDA, Paulo de. Manual do Código Civil Brasileiro. Rio de Janeiro: Jacintho Ribeiro dos Santos, 1924. p. 121/vol.VIII. 
Como o acordo real é um contrato, é possível que não se cumpra algum requisito legal para sua validade, tornando-o ineficaz. No entanto, como ele é realizado diante do oficial e este tem como atribuição analisar a regularidade do ato, dificilmente o contrato será anulado, o que gera maior segurança ao direito de propriedade.

Apontadas as principais características do sistema, chega o momento de discorrer sobre alguns princípios que o regem.

O primeiro deles é o da inscrição. Por este princípio, há a obrigatoriedade de que todas as modificações jurídico-reais dos imóveis sejam inscritas nos assentos registrais. A inscrição é constitutiva, ou seja, a transferência da propriedade só terá efeitos se o processo de registro proporcionar a inscrição do negócio jurídico no livro registral. Ainda, gera presunção de que a pessoa inscrita é a titular do direito. E, por fim, garante ao terceiro de boa-fé a não violação de seu direito, se adquirido com base nas informações do registro. ${ }^{316}$

O princípio da inscrição está ligado ao princípio da continuidade. Para que seja feita a inscrição é obrigatório que o alienante conste nos livros registrais como proprietário, caso contrário, o ato é negado. Dessa maneira, para que se forme uma cadeia registraria, todos os atos referentes ao imóvel devem ser inscritos em sua folha, o que proporciona maior segurança às informações contidas no livro. Como exemplo, pode-se apontar a necessidade do herdeiro inscrever-se como proprietário no registro antes de alienar o bem. ${ }^{317}$

Outro princípio norteador desse sistema é a legitimidade material, que se baseia no desdobramento do acordo de vontades para a transferência de domínio. Como já foi visto, primeiro, as partes manifestam suas vontades por meio de um negócio obrigacional (ex. compra e venda, permuta) e depois, perante o ofício de registro fundiário, concordam em operar a modificação real, cujos efeitos independem da causa obrigacional. ${ }^{318}$ Em outras

\footnotetext{
$\overline{316}$ Ressalta-se que no sistema alemão a inscrição só constitui direitos quando a mutação jurídico-real for inter vivos. JARDIM, Mônica. O sistema registral germânico. Revista de Direito Imobiliário, São Paulo, n. 59, ano 28, p. 224 e $225,2005$.

317 Soriano de souza Neto, José. Publicidade Material do Registro Imobiliário: efeitos da transcrição. Recife: [s.n.], 1940. p. 68.

${ }_{318}$ Bueno, Fernando Euler. Effeitos da transcripção no regime do Código Civil Brasileiro. São Paulo: Revista dos Tribunais, 1941. p. 17.
} 
palavras, o acordo real é um prolongamento do negócio obrigacional, constituindo-se em um modo de executar, de fazer cumprir o negócio. ${ }^{319}$

Como a modificação do direito independe da causa jurídico obrigacional, ela não vem expressa no acordo de vontades. Dessa maneira, o acordo de vontades tem como objeto apenas a transmissão da propriedade, não importando se é caso de compra e venda, permuta, doação ou ainda se há ou não vício no negócio. ${ }^{320}$

O que permite a transferência de titularidade é a inscrição, baseada nesse acordo real abstrato, realizado diante de um ofício de registro fundiário. Diz-se abstrato porque sua eficácia independe da causa jurídica que o gerou (ex. compra e venda, permuta), ou seja, se a causa jurídica por algum motivo desaparecer (ex. causas de nulidade), o alienante terá direito apenas a uma ação pessoal, baseada em enriquecimento injusto do adquirente. Jamais poderá alcançar a modificação real inscrita no registro, que continuará eficaz. ${ }^{321}$

Também de grande importância no sistema registrário alemão é o princípio da fé pública. ${ }^{322}$ Ele se aplica unicamente aos casos em que ocorra um negócio jurídico, não tendo efeitos sobre adjudicação judicial ou sucessão causa mortis. Por esse princípio, a boa fé afasta

\footnotetext{
319 JARDIM diferencia o negócio obrigacional e o acordo real da seguinte forma: "A distinção entre negócio obrigacional e acordo real encontra-se no objecto: o do primeiro consiste em obrigações das partes, e o de segundo num direito real. O negócio obrigacional limita-se a vincular as partes, enquanto que o acordo real produz uma modificação real. O negócio obrigacional obriga as partes a celebrar o negócio real, encerra a causa do negócio dispositivo, mas os seus efeitos produzem-se exclusivamente inter partes, desenvolvem-se na pura esfera dos direitos obrigacionais. Por isso, o negócio obrigacional carece, totalmente, de transcendência real. O negócio real visa a constituição, transmissão, modificação ou extinção dos direitos reais, é um contrato abstracto que actua desconectado da causa e os seus efeitos produzem-se com absoluta independência da existência ou validade daquela. A ausência ou nulidade da causa só pode fundar uma acção pessoal tendente a remediar o enriquecimento injustificado". O sistema registral germânico. Revista de Direito Imobiliário, São Paulo, n. 59, ano 28 , p. 223 e 224, 2005.

${ }^{320}$ Soriano de souza Neto, José. Publicidade Material do Registro Imobiliário: efeitos da transcrição. Recife: [s.n.], 1940. p. 79.

${ }^{321}$ Bueno, Fernando Euler. Effeitos da transcripção no regime do Código Civil Brasileiro. São Paulo: Editora Revista dos Tribunais, 1941.p. 17.

${ }^{322} \mathrm{O}$ princípio da fé pública ou da proteção do comércio opõe-se ao princípio da eficácia jurídica formal e ambos constituem as duas maneiras pelas quais o princípio da publicidade material pode ser executado. Segundo SoRIANO NETO, no princípio da eficácia jurídica formal, a inscrição no registro fundiário opera a modificação jurídica pleiteada mesmo que a inscrição seja contrária ao direito. Assim, por exemplo, persiste a inscrição decorrente de falsificação na qual o inscrito de má-fé colaborou. A pessoa que de má-fé adquiriu o bem imóvel, continua com o seu direito, restando ao prejudicado apenas o ressarcimento na esfera obrigacional, com fundamento no ato ilícito ou no enriquecimento sem causa, no entanto, esta ação obrigacional não pode ser movida contra os herdeiros singulares, mesmo que estes também estejam de má-fé, ou seja, não cabe de forma alguma retificar a inscrição. Publicidade Material do Registro Imobiliário: efeitos da transcrição. Recife: [s.n.], 1940. p. 90.
} 
a falta de direito do transmitente e assegura que nenhum direito não inscrito possa limitar ou invalidar aquele contido no assento. ${ }^{323}$ Em outras palavras, a inscrição purifica a aquisição de terceiro de boa-fé, ainda que haja diferença entre o real proprietário e aquele inscrito no livro registral.

Como conseqüência, aquele que de boa-fé, confiando nas informações existentes no assento registral, adquire a título gratuito ou oneroso por meio de um negócio jurídico um bem imóvel, tem assegurado seu direito, por mais que se prove que o alienante não era o real titular do bem. A proteção ao agente de boa-fé decorre da segurança que o assento registral deve proporcionar. ${ }^{324}$

Quanto ao proprietário prejudicado, cabe a ele pleitear os danos sofridos. A ação será intentada perante o adquirente de boa-fé, se a aquisição foi a título gratuito e ante o falso vendedor, se a título oneroso. No entanto, se o adquirente ainda estiver com a coisa em seu poder, como decorrência da ação obrigacional de enriquecimento sem causa, deverá restituíla. ${ }^{325}$

Perceba que o sistema alemão ao adotar o princípio da fé pública, prioriza a segurança do comércio, já que assegura as relações comerciais ao proteger aquele que de boafé confiou nos livros registrais. No entanto, ao mesmo tempo, o sistema não deixa o real proprietário descoberto, prevendo a restituição do valor do bem, ou ainda, em alguns casos, do próprio imóvel. Ademais, ao afastar a presunção “juris et de jure" possibilita o questionamento da validade dos assentos, possibilitando a correção de possíveis inexatidões, ou seja, adotou medidas que buscam garantir também a segurança do direito de propriedade.

Fernando Euler Bueno chega a afirmar que os legisladores alemães não dispuseram acerca da presunção absoluta do registro (contradizendo um princípio que existia

\footnotetext{
${ }^{323}$ JARDIM, Mônica. O sistema registral germânico. Revista de Direito Imobiliário, São Paulo, n. 59, ano 28, p.232 e 233, 2005.

${ }^{324}$ FonseCA lembra que diferentemente do direito prussiano que apenas protegia o adquirente a título oneroso, igualando aquele a titulo gratuito ao que agia de má-fé, o código civil alemão previu a fé publica do registro com eficácia plena em relação a todos os adquirentes que estivessem de boa-fé, incluindo também o adquirente a titulo gratuito. Effeitos da transcripção. Revista dos Tribunais, vol. 107, ano 26, p. 442 e 443, 1937.

325 JARDIM, Mônica. O sistema registral germânico. Revista de Direito Imobiliário, São Paulo, n. 59, ano 28, p. 232 e $233,2005$.
} 
em parte da confederação dos Estados Germânicos antes da promulgação do Código Civil), visando à conciliação entre a segurança do crédito e do direito de propriedade. ${ }^{326}$

A instauração e funcionamento do registro fundiário alemão só se tornaram possíveis graças a um direito imobiliário formal, que foi elaborado considerando cada um dos princípios do direito material, tendo em vista obter não só a segurança do comércio, mas também evitar sérias ameaças à segurança da propriedade. ${ }^{327}$

Dessa maneira, para facilitar as inscrições, a lei adjetiva previu que aquelas referentes a imóveis de uma mesma localidade deveriam ser realizadas em um único ofício, o que facilitaria as buscas. Ainda, para contribuir com a presunção de veracidade do registro, exigiu-se que o contrato passasse pela análise de um juiz habilitado que examinasse a qualidade do alienante e a vontade das partes. Ademais, para que o princípio da fé pública tomasse forma, o sistema foi aparelhado com um cadastro.

Segundo Bueno, o cadastro nada mais é do que uma segunda via da superfície nacional que é recortada em propriedades imóveis, recortes esses que juntos constituem o registro fundiário. Toda vez que o terreno possuir unicamente para si uma folha no livro registrário, na qual esteja inscrito o nome do proprietário, será correto afirmar que o imóvel “tal" está inscrito em nome do proprietário "tal". Essa conclusão não será possível quando o registro não tiver cadastro nem fólio real, pois pode acontecer que um imóvel conste mais de uma vez em seus assentos, sem que o responsável pelo registro possua qualquer meio para impedir ou denunciar. Assim, para BuEno, sem os cadastros e sem os fólios reais, não é possível instituir o princípio da fé pública. ${ }^{328}$

Com efeito, esse sistema explica-se na Alemanha pelos antecedentes históricos, ou seja, pela possibilidade do cadastro. Propriedade cadastrada é propriedade individualizada (ou seja, delimitada, definida). Na Alemanha, essa individualização só se tornou possível porque as propriedades ficaram durante muitos anos sob o domínio de uma mesma família, havendo

\footnotetext{
${ }^{326}$ Effeitos da transcripção no regime do Código Civil Brasileiro. São Paulo: Editora Revista dos Tribunais, 1941. p. 18.

${ }^{327}$ Bueno, Fernando Euler. Effeitos da transcripção no regime do Código Civil Brasileiro. São Paulo: Revista dos Tribunais, 1941.p. 20.

${ }^{328}$ Ibidem., p. 23.
} 
poucas mutações reais. Acrescenta-se a isso o fato da Administração tomar todas as cautelas no momento de analisar cada título, o que contribuiu para a formação de um sistema seguro. ${ }^{329}$

Definidas as principais características dos sistemas francês e alemão, fica mais claro entender as discussões dos legisladores e juristas brasileiros, principalmente em momentos anteriores a aprovação do Código Civil de 1916, quanto ao modelo registrário que deveria ser adotado no país.

Quando Clóvis Bevilaqua, em 1899, foi convidado pelo Governo de Campos Sales para elaborar o Código Civil, ele não podia ignorar os debates ao redor do direito imobiliário registral. Ouvindo as críticas que os próprios franceses faziam ao seu sistema imobiliário, sugeriu a adoção de um modelo mais parecido com o alemão, semelhante no que fosse possível, já que este era fundamentado em uma propriedade cadastrada e o cadastro estava muito distante da realidade brasileira. ${ }^{330}$

Assim, o projeto apresentado em nenhum momento dispunha sobre o cadastro dos imóveis ou sobre o princípio da fé pública, característicos do sistema alemão. O próprio BEvilaqua chegou a afirmar que não era sua intenção destruir o sistema pré-existente e substituí-lo por um totalmente novo. A idéia era reforçar o sistema já aplicado, consolidando a propriedade imóvel, ao corrigir falhas e insuficiências da legislação vigente. ${ }^{331}$

Antes de abordar as modificações que o projeto sofreu durante o processo legislativo, vale transcrever seus dispositivos originais relativos à transmissão da propriedade imóvel pelo título ${ }^{332}$. São eles:

“Art. 605. Adquire-se a propriedade immovel entre vivos: I - Pela inscripção no registro predial, do título hábil para transferi-la. (...)”. (art. 534 Projeto Câmara e 530 Código Civil)

“Art. 609. - Estão sujeitos á inscripção no registro predial, os actos hábeis para transferir a propriedade immovel entre vivos; sejam gratuitos ou onerosos”. (art.535 Projeto Câmara e 531 do $\mathrm{CC})$

${ }^{329}$ Lacerda, Paulo de (Org.). Manual do Código Civil Brasileiro. Rio de Janeiro: Jacintho Ribeiro dos Santos, 1924. p. 116.

${ }^{330}$ BuEno, Fernando Euler. Effeitos da transcripção no regime do Código Civil Brasileiro. São Paulo: Revista dos Tribunais, 1941. p. 24.

${ }^{331}$ Em Defeza do projecto de Código Civil Brazileiro. Rio de Janeiro: Francisco Alves, 1906. p.126.

${ }^{332}$ Apenas foram transcritos os dispositivos pertinentes a pesquisa. 
“Art. 996. O registro predial comprehende: $1^{\circ}$ - A inscripção dos títulos de transmissão da propriedade sobre immoveis; (...) $4^{\circ}$ - A descripção dos immoveis cuja acquisição ainda não conste do mesmo registro". (art. 857 Projeto Câmara e 856 do CC)

"Art. 999. Quando um direito real é inscripto no registro predial em favor de uma pessoa, presume-se que esse direito lhe pertence". (860 Projeto Câmara e 859 do CC)

"Art. 1.000. Se o teor do registro predial em relação a um direito real não traduz a verdade da situação jurídica existente, a pessôa prejudicada por elle póde reclamar a sua rectificação por acção competente". ${ }^{333}$ (art. 861 do Projeto Câmara e 860 do CC)

A Comissão Revisora foi nomeada pelo governo para analisar o projeto e os pareceres elaborados por juristas sobre o mesmo. Após inúmeras sessões, apresentou apenas uma emenda ao artigo 605 do projeto que consistia na inclusão do $\S 4^{\circ}$ do art. $8^{\circ}$ do decreto n. 169-A de 1890. Este parágrafo previa:

"A inscrição não induz prova de domínio que fica salvo a quem de direito"

Os trabalhos da Comissão Revisora terminaram em 29 de março 1900, após 51 sessões. Em seguida, em 9 de agosto do mesmo ano, uma nova Comissão foi nomeada pelo Governo, com a participação de Bevilaqua. Seguiram-se mais 12 sessões que terminaram em 17 de novembro de 1900, quando em mensagem do Presidente da República foi apresentado ao Congresso o Projeto revisto. ${ }^{334}$

Terminada a etapa de análise pelas Comissões, criadas diretamente pelo Governo, iniciaram-se as discussões nas Casas legislativas.

A Câmara dos Deputados nomeou uma Comissão de 21 membros para discutir o projeto revisto, oferecendo o período entre as sessões legislativas de 1900 e 1901 para juristas, Tribunais, Faculdades de Direito apresentarem suas sugestões. Em 18 de janeiro de 1902, após 65 sessões, Sylvio Romero apresentou o parecer da Comissão, que trouxe algumas

\footnotetext{
333 Alves, João Luiz. Código Civil da Republica dos Estados Unidos do Brasil annotado. 2aed., São Paulo: Saraiva \& Cia, 1935. p. 494, 495, 746, 748 e 749/vol.1. Nessa obra o autor apresenta os artigos da maneira como estavam escritos no projeto de Bevilaqua, no projeto da Câmara e, por fim, como ficaram.

${ }^{334}$ Pontes de Miranda. Fontes e evolução do Direito Civil Brasileiro. Rio de Janeiro: Pimenta de Mello \& C., 1928. p. 108 e 109.
} 
modificações ao projeto. Entre elas, houve a supressão do inciso IV do art. $996^{335}$, o que excluiu a exigência de que constasse no registro a descrição da propriedade imóvel. Essa mudança afastou ainda mais o sistema registral brasileiro de uma possível adoção do cadastro imobiliário, individualizando a propriedade.

Além do inciso IV do artigo 996, a Comissão da Câmara dos Deputados excluiu o parágrafo único do art. 605 do projeto (que na Casa chegara como 619) que tinha sido inserido pela Comissão Revisora nomeada pelo Governo. ${ }^{336}$.

A eliminação do parágrafo único, sugerida por Luiz Domingues, gerou divergências entre os juristas, afinal, muitos entenderam a exclusão do dispositivo como uma manifestação expressa do legislador de que havia optado pelo sistema germânico, devendo a transcrição induzir prova de domínio. Outros não interpretaram dessa mesma maneira, uma vez que o modelo alemão incluía além do princípio da presunção, o da fé pública que não havia nem mesmo sido citado no projeto. ${ }^{337} 338$

Mas a ausência do princípio da fé pública não era o único aspecto que diferenciava o projeto Bevilaqua do sistema alemão. O projeto também não tratava sobre o título abstrato. Segundo José Augusto Cesar, felizmente, o projeto de Código Civil brasileiro não tinha seguido o princípio admitido no Código alemão de não exigir para a transferência de um bem imóvel um motivo econômico ou jurídico que a justificasse. Afinal, isso enfraquecia o direito de propriedade já que era dado maior força a fé pública do registro predial do que ao domínio sobre o bem propriamente dito, ${ }^{339}$ ou seja, não era certo preterir a segurança do direito de propriedade em nome da segurança do comércio.

O projeto modificado pela Comissão da Câmara dos Deputados foi aprovado por essa Casa em 21 de março de 1902. Seu presidente nomeou uma Comissão especialmente

${ }^{335}$ Alves, João Luiz. Código Civil da Republica dos Estados Unidos do Brasil annotado. $2^{\mathrm{a}}$ ed., São Paulo: Saraiva \& Cia, 1935. p. 746/vol.1º.

${ }^{336}$ Projecto do Codigo Civil Brazileiro. Trabalhos da Comissão Especial da Camara dos Deputados. Rio de Janeiro: Imprensa Nacional, 1902, p. 247/vol.VI.

${ }^{337}$ Bueno, Fernando Euler. Effeitos da transcripção no regime do Código Civil Brasileiro. São Paulo: Revistados Tribunais, 1941.p. 28.

${ }^{338}$ Os autores de cada uma das correntes e seus argumentos serão objetos do próximo item.

${ }^{339}$ Prefácio sobre o projeto do Código Civil. In: Ensaio sobre os actos jurídicos. Campinas: Typ da Casa Genoud, 1913. p. 15. 
para redigir os dispositivos do projeto, conforme o que tinha sido aprovado. $\mathrm{O}$ grupo composto por Frederico Borges, Luiz Domingues e Alfredo Pinto (relator), substituiu alguns termos que achava, nas palavras de seus membros, "improprios e dissonantes" sem contudo alterar os princípios já assentados e as disposições consagradas pelo voto da Comissão Especial. ${ }^{340}$

Concluídos os trâmites na Câmara dos Deputados, o projeto seguiu para o Senado, no qual uma Comissão Especial presidida por RuY BARBosa o esperava. Ao receber os 8 volumes do Projeto do Código Civil, Ruy Barbosa entendeu que antes da análise pela Casa, seria fundamental que se fizesse uma revisão do texto legislativo ${ }^{341}$ pois, para que o Código tivesse a longevidade que se esperava, a linguagem deveria ser clara e precisa. Além da melhoria na linguagem, RuY BARBOSA destacou inúmeros erros gramaticais, imprecisões e condenou novidades na fraseologia jurídica, em um parecer publicado em 1902. ${ }^{342} 343344$

No relativo às disposições referentes à transmissão da propriedade imóvel inter vivos, algumas correções foram feitas. Entre elas, destaca-se a relativa à substituição da

\footnotetext{
${ }^{340}$ Projecto do Codigo Civil Brazileiro. Trabalhos da Comissão Especial da Camara dos Deputados. Rio de Janeiro: Imprensa Nacional, 1902, p. 547/vol.VI. Ressalta-se que os artigos referentes à transmissão da propriedade imóvel também sofreram mudanças em sua redação, porém nenhuma que tenha alterado o conteúdo dos dispositivos.

${ }^{341}$ Segundo San Tiago Dantas, é estranho que o presidente da Comissão Especial do Senado tenha ficado preso às questões de forma e ignorado questões de fundo. Para alguns autores, a idéia de Rui Barbosa era refazer o Projeto de Código Civil, ambicionando para si a elaboração de tão grandiosa obra. Nesse sentido, o parecer de 1902 corrigindo gramaticalmente o projeto de Bevilaqua teria como função destruí-lo, tirar sua credibilidade. Já o parecer apresentado em 1905 seria o início do Projeto Rui Barbosa que futuramente o Congresso converteria em lei. Obras Completas de Rui Barbosa. Parecer Jurídico. Rio de Janeiro: Oficina Gráfica do Departamento de Imprensa Nacional, 1968. p. XV/vol.XXXII, Tomo III.

${ }^{342}$ Rui Barbosa. Obras Completas de Rui Barbosa. Parecer sobre a redação do Código Civil. Rio de Janeiro: Oficina Gráfica do Departamento de Imprensa Nacional, 1949. p. 1, 4 e 7/vol.XXIX, Tomo I.

${ }^{343}$ Depois de apresentar vários exemplos de disposições do projeto que deveriam sofrer algum tipo de alteração e afirmar que as notas por ele apresentadas a cada artigo visavam sua melhora, Rui Barbosa diazia: “... aventureime, por obter alguma coisa....Não presumo, pois, ter-me aproximado sequer da correção, que entrevejo. Obra emendada não pode ser obra perfeita, ainda quando a mão, que emenda, seja capaz da perfeição, quanto mais estando tão aquém dessa altura. As correções, que alvitro, não armam senão a melhorar, quanto eu saiba, o trabalho primitivo. Urgidas pela escassez do tempo e obrigadas a cingir-se aos moldes da mão-de-obra alheia muitas delas suscetíveis também, por sua vez, de outros reparos, ficam apenas a meio caminho do que a mim mesmo, com todas as desvantagens da minha inferioridade, me seria possível, se me tivesse cabido a honra da primeira redação, ou se, para a rever, dispusesse de prazo razoável”. Ibidem., p.18 e 19.

${ }^{344}$ Com o parecer literário de Ruy Barbosa, iniciou-se grande polêmica, principalmente com Ernesto Carneiro Ribeiro que publicou as "Ligeiras Observações", que foram opostas por Ruy Barbosa por meio da "Réplica"e respondidas por Ribeiro com "A Redação do Código Civil". LaCerda, Paulo de. Codigo Civil Brasileiro. Rio de Janeiro: Jacintho Ribeiro dos Santos Editor, 1916. p. LV. Destaca-se que estas obras não serão analisadas neste trabalho, pois se despenderia muito tempo com questões meramente gramaticais e de redação.
} 
palavra "transcrição" por "inscrição" nos artigos 534 a 539 do projeto. Segundo Ruy BARBosA, todas as legislações brasileiras anteriores ao projeto que se reportavam ao registro, reservavam o termo "inscrição" para o registro de hipotecas e, "transcrição", para a constituição e transmissão dos outros direitos reais sobre imóvel. Essa tendência era acompanhada também pelas legislações européias, tais como a francesa e a italiana. Apenas o Código Alemão limitava-se a adotar o termo "inscrição" para o registro de qualquer direito. Assim, seguindo a tradição e a propensão dos países europeus, não havia razão para substituir o termo "inscrição" por "transcrição". Tal inovação, além de retirar um vocábulo do direito predial, poderia gerar confusões na prática registral, não trazendo qualquer vantagem. ${ }^{345}$

Interessante notar que, provavelmente por um descuido na elaboração do parecer, Ruy Barbosa tenha utilizado no artigo 539 o termo "inscrição" no lugar que, seguindo seu próprio ensinamento, caberia apenas a palavra "transcrição". 346

Para Bevilaqua, os argumentos utilizados para se restringir o termo "inscrição" ao registro de hipotecas, não estendendo sua utilização para os atos de constituição e transmissão da propriedade, eram frágeis e contrários ao sentido real da palavra. Sem citar Ruy Barbosa, o autor do projeto criticava os raciocínio da Comissão de Comissão do Senado (ou seja, de RuY BARBOSA) dizendo que se prevalecesse a idéia de se manter a tradição, nenhuma alteração seria feita na linguagem jurídica. Ademais, concordava que em países como a França e a Itália, havia distinção entre os dois termos, no entanto, entendia que isso ocorria porque nesses países a transcrição correspondia ao sentido real dessa palavra, ou seja, havia cópia integral do título. Como no Brasil isso não ocorria, já que o registro dos atos translatícios fazia-se por extrato, era adequada à palavra inscrição. ${ }^{347}$

\footnotetext{
${ }^{345}$ Rui Barbosa. Obras Completas de Rui Barbosa. Parecer sobre a redação do Código Civil. Rio de Janeiro: Oficina Gráfica do Departamento de Imprensa Nacional, 1949. p. 191 e 192/vol.XXIX, Tomo I.

${ }^{346} \mathrm{O}$ artigo 539 corrigido por Rui Barbosa passou a ter a seguinte redação:

"Sobrevindo falência ou insolvência do alienante entre a prenotação do título e a sua transcrição por atraso do oficial de justiça, ou dúvida julgada improcedente, far-se-á, não obstante, a transcrição exigida, que retroage, nesse caso, à data da prenotação.

Se, porém, ao tempo da inscrição ainda não estiver pago o imóvel, o adquirente, notificado da falência ou insolvência do alienante, depositará em juízo o preço". (grifo nosso).

1949. Ibidem., p. 193.

${ }^{347}$ Em Defeza do projecto de Código Civil Brazileiro. Rio de Janeiro: Francisco Alves, 1906. p. 441-443.
} 
Como há diferenças conceituais entre os dois vocábulos, e o projeto dispunha sobre o registro por extrato, nada mais lógico seria que Ruy BARBOSA, diante de sua preocupação por uma língua impecável, tivesse feito uso da palavra adequada.

Esta foi uma das poucas correções contestadas por Bevilaqua. Em regra, diante das críticas relativas aos aspectos gramaticais e de redação do projeto de Código Civil, o jurista tentou afastar-se de uma discussão que entendia ser "bysantina" e que apenas serviria para perda de tempo e de oportunidade em aprovar o projeto no Congresso. Bevilaqua lamentava ter a discussão se centralizado em aspectos de estilo e gramática, que por serem secundários, jamais poderiam ter postergado a análise dos princípios jurídicos que o texto trazia. Para o autor era uma "inconseqüência injustificável preterir a essencia pela fórma". ${ }^{348}$

Várias correções e melhorias na redação foram feitas por Ruy BARbosa, ${ }^{349}$ e pelo menos no que diz respeito aos dispositivos relativos à transmissão da propriedade imóvel inter vivos, pode-se afirmar que as modificações conseguiram atingir o intuito indicado pelo seu revisor gramatical, tal seja, tornar a linguagem do Código Civil mais clara e simples. Porém, não é possível desconsiderar os apontamentos de Bevilaqua. Se o tempo despendido com os aspectos gramaticais tivesse sido também aplicado para a análise jurídica dos dispositivos do projeto, o Código Civil teria sido muito beneficiado.

A Comissão Especial do Senado também permitiu que profissionais e interessados apresentassem pareceres sobre o projeto de Código Civil. Em 1902, várias sugestões de pequenas mudanças foram expostas.

No relativo à transmissão da propriedade imóvel pelo registro do título, o Sr. J. M. De Azevedo Marques sugeriu a inclusão do termo "hábil" no inciso I do artigo 534 que passaria a ter a seguinte redação: "Adquire-se a propriedade imóvel: I - Pela inscrição do título "hábil"

\footnotetext{
${ }^{348} \mathrm{O}$ autor ainda afirmava que os antagonistas do projeto desejavam adotar uma língua impecável que nunca tinha sido falada pelo povo e que acreditavam ter sido idealmente criada pelos escritores de que mais gostavam. Em Defeza do projecto de Código Civil Brazileiro. Rio de Janeiro: Francisco Alves, 1906. p. X e XI.

${ }^{349}$ Como exemplo de outra correção feita por Rui Barbosa, pode-se apontar a relativa ao art. 539. Nele há a substituição da palavra "retrotrair" adotada no projeto por "retroagir". A justificativa para a modificação está no fato de que o verbo "retrotrair" foi utilizado na voz neutra, enquanto que, gramaticalmente, só admite a voz passiva. Obras Completas de Rui Barbosa. Parecer sobre a redação do Código Civil. Rio de Janeiro: Oficina Gráfica do Departamento de Imprensa Nacional, 1949. p. 193/ vol.XXIX, Tomo I.
} 
de transferência no registro predial da situação do imóvel"350. O receio de Azevedo MARques era que uma escritura nula, depois de inscrita nos livros registrais, transferisse domínio. Assim, para evitar-se arbítrio dos juízes e tribunais e "perturbação" das partes, o melhor seria que viesse escrito na lei que a escritura nula e inábil não transferia a propriedade. A medida, segundo o autor, só seria necessária se o Senado mantivesse seu entendimento de excluir o parágrafo único do art. 619 (antigo art. 605) que dispunha "A inscrição não induz prova de domínio, que fica salvo a quem for". ${ }^{351}$ Em outras palavras, a inclusão do termo "hábil" impediria que a segurança do comércio prevalecesse sobre a segurança do direito de propriedade, em caso da previsão do parágrafo único do art. 619.

Bevilaqua apresentou parecer, discordando das considerações feitas por Azevedo MARQues. O autor do projeto achava positiva a exclusão do parágrafo único do art. 619, já que para ele havia antinomia entre esse dispositivo e o artigo 860 do projeto revisto, que dispunha "a inscrição do direito real em favor de uma pessoa faz presumir que esse direito lhe pertence". Ademais, no direito brasileiro, a transcrição era modo de adquirir o domínio de imóveis e aquele que dizia o contrário, confundia-se com o $\S 4^{\circ}$ do art. $8^{\circ}$ da Lei Hipotecária de 1864 da qual, aliás, esse parágrafo tinha sido copiado. ${ }^{352}$

Segundo Bevilaqua, o objetivo era fazer da transcrição um modo de tradição dos imóveis, sem que ela purificasse as nulidades. No entanto, não era porque a transcrição, quando realizada a non domino, não produzia efeitos, que ela não podia ser considerada modo de aquisição de propriedade. Assim, não havia motivo para restabelecer o parágrafo único do art. 619, ou fazer a alteração pleiteada por AzEVEDo MARQUES; afinal, o fato da transcrição não produzir efeitos quando o título fosse nulo, não retirava sua condição de tradição solene. ${ }^{353}$

\footnotetext{
${ }^{350}$ Segundo Azevedo Marques, a inclusão de "hábil" tinha sido sugestão do Sr. Barbosa Lima. Projecto de Codigo Civil Brazieliro. Trabalhos da Commissão Especial do Senado. Pareceres e emendas enviados á Commissão. Rio de Janeiro: Imprensa Nacional, 1904. p. 17/vol.III.

${ }^{351}$ Emenda apresentada em 17 de abril de 1902. In: Projecto de Codigo Civil Brazieliro. Trabalhos da Commissão Especial do Senado. Pareceres e emendas enviados á Commissão. Rio de Janeiro: Imprensa Nacional, 1904. p. 16 e 17/vol.III.

${ }^{352}$ Emenda apresentada em 3 de junho de 1902. In: Projecto de Codigo Civil Brazieliro. Trabalhos da Commissão Especial do Senado. Pareceres e emendas enviados á Commissão. Rio de Janeiro: Imprensa Nacional, 1904. p. 76/vol.III.

${ }^{353}$ Emenda apresentada em 3 de junho de 1902. In: Projecto de Codigo Civil Brazieliro. Trabalhos da Commissão Especial do Senado. Pareceres e emendas enviados á Commissão. Rio de Janeiro: Imprensa Nacional, 1904. p. 76 e 77/vol.III.
} 
Outra discussão sobre o projeto do Código Civil foi trazida por EulÁLIO DA CosTA Carvalho. Depois de repetir a opinião de Ruy Barbosa quanto à adoção dos termos "transcrição" e "inscrição", CARVALHO defendeu a transcrição seja realizada para todos os atos de transmissão de propriedade imóvel, inclusive para os atos causa mortis (o projeto só exigia a transcrição para os atos inter vivos). O objetivo era fazer com que houvesse uma plena publicidade dos atos de transmissão, que só poderia ser ofertado pelo registro. Segundo CARvalho, como o inventário poderia ser processado na última comarca do de cujos, as informações quanto à transferência de domínio ficavam esparsas. Se o registro dos atos causa mortis fosse obrigatório, ele seria realizado na comarca em que o bem estivesse localizado, concentrando as informações. ${ }^{354}$

A emenda apresentada por CARVALHO é extremamente pertinente, afinal, como já visto no capítulo anterior, o registro predial que possui o encadeamento dos atos relativos ao imóvel tem mais chance de oferecer ao interessado informações corretas sobre o bem.

Três anos após o parecer literário, em 1905, Ruy Barbosa publicou um outro, que diferentemente daquele de 1902, tratou de matéria jurídica. Trazia apenas dois dispositivos referentes à pessoa física e o capítulo geral das pessoas jurídicas, seguindo a matéria do projeto com algumas emendas. Esse parecer, que cobria apenas os primeiros vinte artigos da Parte Geral do Código Civil, acabou sendo abandonado, diante do afastamento de RuY BARBosa por alguns anos da Comissão Especial do Senado.

No entanto, apesar do parecer jurídico ter pouca extensão, Feliciano Pena, presidente da Comissão Especial do Senado em 1908, pediu a RuY BARBosa o texto incompleto para utilizá-lo nos trabalhos legislativos. Em 1910, após a campanha civilista e com o retorno de Ruy Barbosa às atividades do Senado, Feliciano Pena concedeu lhe um ano e meio para a conclusão do parecer (a Comissão achava fundamental que o projeto fosse a plenário acompanhado de um parecer jurídico). Como RuY BARBOSA queria dois anos e o prazo não foi prorrogado, declinou da incumbência acreditando que a limitação do tempo poderia prejudicar sua execução. Assim, o parecer jurídico de Ruy BARBosa não foi finalizado e o projeto de

${ }^{354}$ Emenda apresentada em 4 de julho de 1902. In: Projecto de Codigo Civil Brazieliro. Trabalhos da Commissão Especial do Senado. Pareceres e emendas enviados á Commissão. Rio de Janeiro: Imprensa Nacional, 1904. p. 99/vol.III. 
Código Civil de Bevilaqua continuou seus trâmites legislativos, transformando-se em lei alguns anos mais tarde, trazendo do político e jurista apenas as reformas de linguagem. ${ }^{355}$

Após vários anos no Senado sob análise de seus membros e da Comissão Especial, o projeto foi enviado em 31 de dezembro de 1912 à Câmara dos Deputados com 1.757 emendas, praticamente de simples redação, baseadas nas correções apresentadas por RuY BARbosa em 1902. ${ }^{356}$

Uma Comissão Especial foi nomeada para discutir essas mudanças, apresentando parecer em 2 de abril de 1913. Diante dessas idas e vindas, o Congresso Nacional foi convocado extraordinariamente para votar o Código Civil. No entanto, questões políticas impediram seu debate e aprovação. ${ }^{357}$

Em $1^{\circ}$ de julho de 1915, a Câmara discutiu as emendas propostas pelo Senado rejeitando 94, das quais 24 foram mantidas pelo Senado quando do retorno do projeto a essa Casa. Em última votação, a Câmara rejeitou 9 das emendas mantidas, o que foi seguido pelo Senado, aprovando-se o Código Civil. Sancionado em 1915, foi publicado em $1^{\text {o }}$ de janeiro de 1916. ${ }^{358}$

Tendo em vista o projeto de Código Civil apresentada por Clóvis Bevilaqua e as modificações sofridas pelos dispositivos referentes à transmissão da propriedade imóvel pelo registro do título, é possível concluir que nem o sistema francês nem o germânico foram adotados em sua integridade; melhor seria dizer que, apesar das influências dos dois regimes, um novo modo de transferência de domínio foi implantado, trazendo um modelo mais completo do que o previsto na Lei Hipotecária de 1864, porém ainda com imperfeições que só foram corrigidas muitos anos mais tarde.

\subsection{Código Civil de 1916}

\footnotetext{
355 Dantas, San Thiago prefácio em Rui Barbosa. Obras Completas de Rui Barbosa. Parecer Jurídico. Rio de Janeiro: Oficina Gráfica do Departamento de Imprensa Nacional, 1968. p. XXVI e XXIX/vol.XXXII, Tomo III. ${ }^{356}$ Alves, João Luiz. Código Civil da Republica dos Estados Unidos do Brasil annotado. 2aed., São Paulo: Saraiva \& Cia, 1935. p. XXIV/vol.1 $1^{\circ}$

357 Ibidem., mesma página.

358 Ibidem., p. XXV.
} 
Depois de anos de demorado trâmite legislativo, o Código Civil foi promulgado em 1916, passando a vigorar a partir de $1^{\circ}$ de janeiro de 1917. Como foi visto, vários aspectos referentes à transmissão da propriedade imóvel pelo registro do título foram objeto de debates quando da aprovação de cada dispositivo do projeto. Mesmo com o exame minucioso dos parlamentares, a publicação da lei não silenciou os juristas, que passaram a discutir sobre a adequada interpretação que deveria ser feita a cada artigo, havendo ainda aqueles que questionavam a adoção pelo país do sistema registral alemão.

Até a promulgação do Código Civil, o registro de imóveis era tratado em leis esparsas. O novo monumento legislativo reuniu toda a matéria relativa ao sistema de transmissão de bens imóveis, ou seja, o direito material e formal (com todo o procedimento e estrutura que envolvem o registro). Essa previsão não parece ter sido a solução mais acertada.

É claro que a matéria referente à transmissão da propriedade imóvel pelo registro do título não poderia ser excluída do Código. No entanto, o ideal seria que o legislador tratasse sobre o ato de registro e de todas as questões que o envolvem em uma legislação separada, fazendo-se as remissões necessárias. Com a exclusão dos dispositivos registrários do Código Civil, o assunto seria melhor discutido e com maior chance se encontrari-se-iam soluções para o problema da segurança jurídica, que a transmissão de um bem imóvel deveria envolver. $\mathrm{O}$ debate no Parlamento tornar-se-ia mais apurado na medida em que menos artigos seriam objeto de análise, e grupos de estudiosos poderiam com maior facilidade apresentar suas emendas e pareceres. Ademais, não haveria a cobrança pela rápida publicação da lei, podendo ser despendido o tempo necessário.

Afrânio de Carvalho destacava outros aspectos negativos do Código Civil. Primeiro, o fato da matéria relativa ao registro imobiliário estar tão dispersa ao longo do texto legislativo, que dificultava a percepção de que tanto o direito material quanto o formal compunham a unidade registral. Segundo problema, a localização dos dispositivos sobre o registro de imóveis. A matéria era disciplinada no Título III "dos direitos reais sobre coisa alheia", capitulo XI "Hipoteca", Seção VI "Do registro de imóveis" levando o intérprete à falsa impressão de que o registro de imóveis dizia respeito unicamente aos direitos reais sobre coisas alheias e, entre eles, somente sobre a hipoteca. Terceiro, a imprecisão quanto ao uso dos 
termos "transcrição" e "inscrição", adotando o aquele para as transmissões de imóveis e constituição de direitos reais, exceto o hipoteca, e este apenas para este direito de garantia. A imprecisão ocorria porque a tarefa do registrador era a de selecionar os elementos essenciais do título e transferi-los ao assento, ou seja, realizar a "inscrição". 359

Como visto no item anterior, a utilização dos vocábulos em cada um dos casos, não foi fruto de distração, mas sim resultado do consenso entre os parlamentares, encabeçados por Ruy BARBOSA, que o ideal seria seguir a tradição brasileira de aplicação dessas palavras e, como acreditavam, acompanhar aquilo que era comum na legislação estrangeira (exceto na Alemanha).

Acontece que o desejo de manter as tradições, acabou por prejudicar o trabalho nos cartórios imobiliários. Segundo Afrânio de CARvalho, o uso do termo "transcrição" levou muitos oficiais a copiarem integralmente o título, multiplicando a quantidade de livros ${ }^{360}$ e, conseqüentemente, tornando qualquer busca mais demorada.

Concluída essa breve abordagem dos aspectos estruturais do Código Civil quanto ao Registro de Imóveis, que diretamente se relaciona à transmissão da propriedade imóvel inter vivos e as seguranças que a envolvem, passa-se a análise do conteúdo de cada artigo sobre a matéria.

Os primeiros artigos que tratam da transmissão da propriedade imóvel são os seguintes:

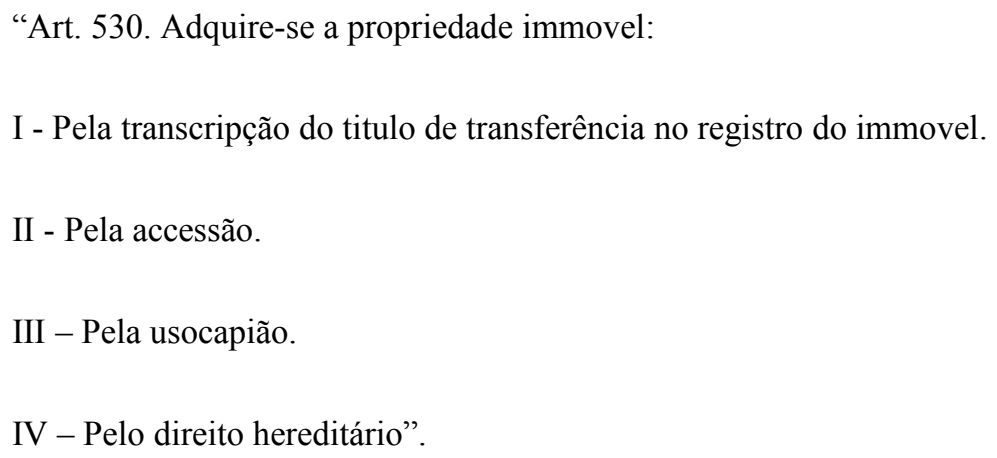

${ }_{359}$ Registro de Imóveis. $3^{\text {a }}$ ed., Rio de Janeiro: Forense, 1982. p. 21 e 22.

${ }^{360}$ Registro de Imóveis. $3^{\text {a }}$ ed., Rio de Janeiro: Forense, 1982. p. 23. 
“Art. 531. Estão sujeitos á transcripção, no respectivo registro, os títulos translativos da propriedade immovel, por acto entre vivos". ${ }^{361}$

Assim, mantendo-se o que já era previsto desde a Lei Hipotecária de 1864, um dos modos de aquisição da propriedade imóvel continuou sendo aquele realizado por meio da transcrição do título (que constitui a causa jurídica do ato de transferência) ${ }^{362}$ nos livros registrais no cartório imobiliário, ou seja, consagrou-se mais uma vez o princípio da inscrição. No entanto, essa consagração não foi absoluta, já que existem direitos sobre imóveis que são adquiridos independentemente da transcrição, como ocorre com os incisos II a IV do art. 530.

Para Soriano Neto, o princípio da inscrição é a única característica do sistema registrário germânico que o Código Civil brasileiro adotou, contrariando a idéia da maioria dos juristas, como será visto adiante. ${ }^{363}$

Outro princípio que pode ser extraído desses artigos e que já estava presente no sistema anterior ao Código é o da legitimidade, não como no sistema alemão de consentimento material (negócio jurídico real e abstrato), mas como prepondera nas outras legislações estrangeiras, do consentimento causal. ${ }^{364}$ Por esse princípio, a transcrição deve ter um caráter legítimo, legal, que corresponda a realidade fática. Porém, como para a transferência do bem é necessária a transcrição do título e este é o fundamento da aquisição, também será a base para a transcrição, o que significa dizer que, se ele apresentar algum vício, o registro poderá ser cancelado. Assim, no sistema registral previsto no Código Civil brasileiro, a causa jurídica ou motivo que gerou a transmissão do bem imóvel é fundamental para a manutenção de seu registro. Um título viciado permite ao prejudicado pleitear o cancelamento da transcrição, já que esta também está eivada com o vício. ${ }^{365}$

${ }^{361}$ LaCerda, Paulo de. Codigo Civil Brasileiro. Rio de Janeiro: Jacintho Ribeiro dos Santos Editor, 1916. p. 170 e 171.

${ }^{362}$ Interessante a crítica de SERPA LoPES, para quem não é correto o uso do termo "título de transferência" ou "título translativo" como faz o artigo do Código Civil. Segundo o autor, há uma imprecisão no termo porque o direito imobiliário brasileiro exige para a transmissão da propriedade imóvel a formalidade da transcrição no Registro de Imóveis, logo, o título em si mesmo nada transfere, sendo unicamente a causa jurídica do ato translativo. Assim, melhor seria dizer "título para a transferência". Tratado de Registros Públicos. $3^{\mathrm{a}}$ ed., Rio de Janeiro: Freitas Bastos, 1955. p. 291/vol.III.

${ }^{363}$ Publicidade Material do Registro Imobiliário: efeitos da transcrição. Recife: [s.n.],1940. p. 74.

${ }^{364}$ Ibidem., p. 83.

${ }^{365}$ Para LysipPo GARCIA, o princípio da legitimidade está expresso no art. 860 do Código Civil que dispõe: "Se o teor do registro de immoveis não exprimir a verdade, poderá o prejudicado reclamar que se rectifique". $O$ Registro de Imóveis: a transcrição. Rio de Janeiro: Francisco Alves, 1922. p. 147/vol.1. Na realidade, parece que 
No que se refere aos títulos, é interessante perceber, seguindo a linha histórica que tem se tentado esboçar ao longo do trabalho, quais atos eles abrangem. No capitulo anterior foi visto que eram considerados títulos apenas as escrituras públicas e os instrumentos particulares. ${ }^{366}$ Em 1916 os legisladores ampliaram este rol.

Para a transferência e constituição de direitos reais sobre imóveis, o Código Civil continuou a exigir a escritura pública, mas apenas para os casos em que o valor do bem ultrapassasse um conto de réis, exceto no penhor agrícola, em que o instrumento particular era sempre admitido. Dessa maneira, o legislador, manteve a exigência do art. 11 da lei n. 840 de $1855^{367}$ apenas aumentando a quantia de 200 mil réis para 1 conto de réis, provavelmente com o intuito de uma atualização monetária.

Além de permitir na transferência de imóveis a transcrição de escrituras públicas e instrumentos particulares, incluiu, na Secção II "Da acquisição pela transcripção do titulo", outros atos como pode ser averiguado no art. 532:

“Art. 532. Serão tambem transcriptos:

I - Os julgados, pelos quaes, nas acções divisórias, se puzer termo á indivisão.

II - As sentenças que, nos inventários e partilhas, adjudicarem bens de raiz em pagamento das dividas da herança.

III - A arrematação e as adjudicações em hasta pública". ${ }^{368}$

Dessa maneira, os livros registrários passaram a conter mais informações acerca do imóvel, possibilitando a formação de uma cadeia de atos que melhor expressavam a situação jurídica do bem. Segundo Bevilaqua, a exigência de transcrição de atos que não

este dispositivo complementava o art. 530, I e 531 e representava a conseqüência para os casos em que o título apresente alguma imperfeição.

${ }^{366}$ Como já visto, o decreto n. 370 de 1890 incluiu, entre os títulos sujeitos a registro, os atos autênticos de países estrangeiros legalizados pelos cônsules brasileiros e traduzidos na língua nacional (art.74).

367 "Art 11. A compra e venda de bens de raiz, cujo valor exceder de duzentos mil réis (200\$000), será feita por escriptura publica, sob pena de nulidade".

${ }^{368}$ Lacerda, Paulo de. Codigo Civil Brasileiro. Rio de Janeiro: Jacintho Ribeiro dos Santos Editor, 1916. p.171. 
dependiam dessa formalidade para transferir a propriedade visava tornar públicas as mutações de domínio e fornecer segurança ao bem imóvel. ${ }^{369}$

Apesar da ampliação dos títulos e do aprimoramento do sistema, algumas imprecisões e ausências mantiveram-se.

Melchiades Picanço indica uma delas. Como o inciso I tratava apenas de "julgados" nas "ações divisórias" e a partilha era um processo administrativo e não uma ação, o autor entendia que era possível questionar a obrigatoriedade do registro da partilha, ${ }^{370}$ o que mais uma vez poderia levar à exclusão dos livros registrais as transferências de bens imóveis causa mortis, mantendo-se a falha nas cadeias registrais e o afastamento de uma possível adoção do princípio da continuidade.

Isto não era o que pensava Bevilaqua. O autor do Código Civil defendia que entre as ações divisórias indicadas pelo inciso I do art. 532, estava, além da divisão de imóvel entre condôminos por titulo singular e entre confinantes, a partilha dos bens da herança. A exigência da transcrição existia mesmo nos casos em que a partilha realizava-se mediante acordo entre herdeiros, afinal, em qualquer dos casos, sendo a divisão amigável ou não, era necessária a homologação pelo juiz. ${ }^{371}$

Garcia acompanhava o entendimento de Bevilaqua ao afirmar que o inciso I incluía casos de partilha, já que o processo de divisão de bens hereditários não era administrativo, mas sim uma das três formas do juízo divisório. $\mathrm{O}$ autor destacava que apesar de não ter sido prevista a transcrição das transmissões causa mortis, o dispositivo ao exigir a transcrição de julgados nas ações divisórias abrandava a falha do Código. ${ }^{372}$

Para João Luiz Alves, o erro do legislador foi incluir na secção "Da aquisição" o inciso referente aos julgados, que colocavam fim a indivisão. Afinal, esse ato judicial era meramente declaratório, não constituindo propriedade, havendo apenas a definição da porção

\footnotetext{
${ }^{369}$ Direito das Coisas. História do Direito Brasileiro. Direito Civil. Obra fac-similar. Brasília: Senado Federal, Conselho Editorial, 2003. p. 151/vol.I.

${ }^{370}$ O direito das cousas (em face do Código Civil). Rio de Janeiro: Comp. Nac. Artes Graphicas, 1926. p. 77.

${ }^{371}$ Direito das Coisas. História do Direito Brasileiro. Direito Civil. Obra fac-similar. Brasília: Senado Federal, Conselho Editorial, 2003. p. 151 e 152/vol.I.

${ }^{372}$ O Registro de Imóveis: a transcrição. Rio de Janeiro: Francisco Alves, 1922. p.123 e 157/vol.1.
} 
do bem que cabia a cada parte. Além de excluir o inciso incoerente, o autor defendia que o Código deveria ter trazido no rol do artigo 532, as sentenças declaratórias de usucapião e o ato de renúncia da propriedade. ${ }^{373}$

Segundo Afrânio de Carvalho, uma outra falha do legislador de 1916 estava no art. 676, que com a expressão "salvo os casos expressos neste Código" levava ao entendimento de que existia no Código Civil a previsão de aquisição de direitos reais, sem a necessidade de transcrição ou inscrição no Registro Imobiliário. Todos os atos inter vivos envolvendo mutações jurídico reais deveriam ser transcritos ou inscritos, pois mesmo aqueles direitos reais que não eram constituídos pelo registro, precisavam dele para sua publicidade perante terceiros. ${ }^{374}$

Como já visto, o Código Civil previa, em seu artigo 530, três casos de aquisição de propriedade imóvel em que não havia necessidade de transcrição do título nos livros registrais, a acessão, a usucapião e o direito hereditário. No entanto, o autor entendia que devido à sua redação e localização, não era possível dizer que a ressalva do art. 676 referia-se a essas três situações. $^{375}$

Perceba que em uma mesma seção (II -“Da aquisição pela transcrição do título”), o Código enumera casos em que a transcrição tem como função apenas dar publicidade ao direito e outros em que objetiva constituí-lo. Como exemplo de mera publicidade, pode-se citar o inciso I art. 532 que prevê a transcrição "dos julgados, pelos quais nas ações divisórias, se puser termo a indivisão". Quanto à transcrição com efeito de constituição, tem-se o mesmo artigo, porém seus incisos II e III.

Para Afrânio Carvalho, o legislador deveria ter separado em dispositivos distintos, os casos em que a transcrição tinha efeito meramente declaratório, daqueles em que constituía direitos. ${ }^{376}$

\footnotetext{
${ }^{373}$ Código Civil da Republica dos Estados Unidos do Brasil annotado. 2aed., São Paulo: Saraiva \& Cia, 1935. p. 496 e $497 /$ vol. $1^{\circ}$.

${ }^{374}$ Registro de Imóveis. $3^{\mathrm{a}}$ ed., Rio de Janeiro: Forense, 1982. p. 26.

${ }^{375}$ Ibidem., mesma página.

${ }^{376}$ Ibidem., p. 28.
} 
Uma inovação importante do Código Civil foi a previsão da presunção de domínio do registro de imóveis. Na legislação anterior, cabia ao possível proprietário provar o seu domínio, o que o levava a ter que rastrear as sucessivas transferências anteriores, até pelo menos atingir o ponto definitivo em que se consumava o prazo de usucapião.

Com a previsão da presunção de domínio, os doutrinadores passaram a questionar quais eram seus efeitos jurídicos.

Vale lembrar que esse debate relacionava-se a outro, já conhecido e histórico que existia desde a exclusão, nos trabalhos preparatórios do Código Civil, do parágrafo proposto pela Comissão Revisora ao art. 605 do projeto "a inscrição não induz prova de domínio que fica salvo a quem de direito". A eliminação desse dispositivo levou muitos autores a concluir que o legislador havia optado pelo sistema germânico, devendo a transcrição induzir prova absoluta de domínio.

Depois da publicação do Código, a discussão alterou-se um pouco. Chegou-se ao consenso de que havia presunção de domínio, mas o debate permanecia quanto à sua extensão, o que significava concluir pela aplicação ou não, pelo regime registral brasileiro, daquela presunção presente no Código Alemão, ou seja, com todos os efeitos que ela gerava.

Surgiram assim duas correntes. A primeira entendia que a consagração do princípio da força probante (ou presunção de domínio) do registro no ordenamento brasileiro gerava uma maior proteção àquele que tivesse seu direito real transcrito. Assim, caso seu domínio fosse questionado, caberia o ônus da prova à pessoa que alegava a incorreção, pois supunha-se que o livro registral exprimia a verdade. Daí se dizer que o princípio da força probante apenas surtia efeitos no campo processual. Representavam esse grupo juristas como Sá Pereira ${ }^{377}$, José Augusto César ${ }^{378}$, Pontes de Miranda ${ }^{379}$, Fernando Euler Bueno ${ }^{380}$ e Gonçalves de Oliveira ${ }^{381}$.

\footnotetext{
377 Direito das Cousas. Art. 524-678. In: LaCerda, Paulo de. Manual do Código Civil Brasileiro. Rio de Janeiro: Jacintho Ribeiro dos Santos, 1924, p. 130/vol.III.

${ }^{378}$ Sobre o Registro de Imóveis. Revista da Faculdade de Direito de São Paulo, São Paulo, n. 31, p. 427, set.1935.

${ }^{379}$ Tratado de Direito Predial. Rio de Janeiro: José Konfino Editor, 1947. p. 133 e 134/vol.I.

${ }^{380}$ Effeitos da transcripção no regime do Código Civil Brasileiro. São Paulo: Revista dos Tribunais, 1941.p. 31.

${ }^{381}$ Valor probante do registro de immoveis. Archivo Judiciário/Jornal do Commercio. Rio de Janeiro: Rodrigues \& CIA, 1939. p. 28/vol. LII.
} 
Dessa maneira, esses autores entendiam que o Código Civil, ao aprimorar o sistema de transmissão da propriedade imóvel pelo registro do título, continuou a priorizar o real proprietário do bem, estando ele inscrito ou não, ou seja, buscou-se a segurança do direito de propriedade.

Para a segunda corrente, o princípio da presunção de domínio adotado pelo Código Civil de 1916 fornecia às informações presentes nos livros registrais não apenas aparência de veracidade, mas também, garantia a terceiros de boa-fé total coerência com os aspectos fáticos. Dessa modo, aquele que confiando no assento adquirisse a propriedade de quem não fosse dono, teria seu direito preservado desde que estivesse de boa-fé. Caberia ao prejudicado unicamente pleitear uma indenização com base no enriquecimento sem causa. Para AlmeIDA PRADO, os adeptos dessa corrente entendiam que a presunção de domínio deveria ser absoluta perante terceiros de boa-fé e relativa entre os contratantes e os terceiros adquirentes de má-fé ou a título gratuito. ${ }^{382}$ São adeptos dessa corrente juristas como Bevilaqua ${ }^{383}$, Arnoldo Medeiros da Fonseca ${ }^{384}$, Lysippo Garcia ${ }^{385}$, Philadelpho Azevedo ${ }^{386}$ e Almeida Prado ${ }^{387}$.

Assim, para estes autores, o aprimoramento no sistema de transmissão da propriedade pelo registro do título visava, primordialmente, a segurança do comércio, já que as transações comerciais realizadas com base nos assentos registrais e de boa-fé estariam protegidas de quaisquer reivindicações futuras.

Como será esclarecido mais adiante, o entendimento dessa segunda corrente fazia muitas vezes parecer que os princípios da força probante e da fé pública eram na realidade sinônimos. GARCia inclusive é um dos autores que afirma expressamente essa semelhança na significação dos dois preceitos. ${ }^{388}$ Sem dúvida há inúmeros pontos de contato entre os dois princípios (inclusive os doutrinadores utilizaram o mesmo artigo do Código Civil, 859, para

${ }^{382}$ Transmissão da propriedade imóvel. São Paulo: Saraiva \& Comp.Editores, 1934. p. 156 e 157.

${ }^{383}$ Direito das Coisas.História do Direito Brasileiro. Direito Civil. Obra fac-similar. Brasília: Senado Federal, Conselho Editorial, 2003. p. 147 e 148/vol.I.

${ }^{384}$ O registro immobiliário e sua força probante em face do Código Civil. Archivo Judiciário/Jornal do Commercio. Rio de Janeiro: Rodrigues \& C., 1937. p. 31/vol. XLII.

${ }^{385}$ O Registro de Imóveis: a transcrição. Rio de Janeiro: Francisco Alves, 1922. p. 129 e 148/vol.1.

${ }^{386}$ Registro de Imóveis (Valor da Transcrição). Rio de Janeiro: Jacintho Editora, 1942. p. 5 a 9.

387 Transmissão da propriedade imóvel. São Paulo: Saraiva \& Comp.Editores, 1934. p. 158.

${ }^{388}$ Para o autor, assim que a transcrição é feita, surge uma presunção legal de existência do direito, isto é, o assento passa a servir de prova e os direitos adquiridos por terceiros são protegidos. O Registro de Imóveis: a transcrição. Rio de Janeiro: Francisco Alves, 1922. p. 129 e 148/vol.1. 
justificar a presença de um ou outro) No entanto, eles não podem ser vistos como sinônimos, já que há diferenças significativas. Com a análise dos debates sobre os dois princípios a dessemelhança ficará clara.

As discussões quanto à extensão do princípio da força probante baseavam-se principalmente, na interpretação que deveria ser feita do art. 859 do Código Civil brasileiro. Este previa:

"Presume-se pertencer o direito real à pessoa, em cujo nome se inscreveu, ou transcreveu". 389

O questionamento tornava-se ainda maior porque o legislador havia copiado esse dispositivo do parágrafo 891 do Código Alemão, o qual adotava tacitamente o princípio da força probante relativa entre contratantes e adquirentes de má-fé, e absoluta perante terceiros de boa-fé (a título gratuito ou oneroso). Como a fonte havia sido a legislação germânica, muitos entendiam que o correto seria interpretar o artigo reproduzido da mesma maneira como se fazia com o original.

Para Arnoldo Medeiros da Fonseca, as discussões sobre o projeto, mormente a exclusão do parágrafo único do art. 605, e todos os dispositivos referentes à transmissão da propriedade imóvel evidenciavam a opção do legislador brasileiro, de maneira geral, em adotar o sistema germânico, "em tudo quanto não dependa de cadastro". 390

FonsECA entendia que para obter a resposta quanto à adoção pela legislação brasileira dos princípios da força probante e, conseqüentemente os seus efeitos, os artigos do Código não deveriam ser interpretados de forma literal; o intérprete deveria recorrer a elementos históricos, racionais e sistemáticos, que mostrariam o sentido exato da norma analisada. Só assim, o estudioso perceberia que o texto legal, ao mesmo tempo em que reconhecia a transcrição como modo de aquisição de domínio (art. 530, I), consagrava a presunção de veracidade das declarações contidas nos livros registrais (art. 859) afirmando sua força probante, e admitia a retificação dos assentos (sem determinar até quando estes seriam

${ }^{389}$ Lacerda, Paulo de. Codigo Civil Brasileiro. Rio de Janeiro: Jacintho Ribeiro dos Santos Editor, 1916. p. 230.

390 O registro immobiliário e sua força probante em face do Código Civil. Archivo Judiciário/Jornal do Commercio, Rio de Janeiro: Rodrigues \& C., 1937. p. 29 e 30/vol. XLII. 
possíveis). Apenas com o uso da interpretação racional, podia o estudioso entender que não caberia retificação nos casos em que a situação contida no livro era digna de proteção jurídica, ou seja, quando envolvesse terceiro de boa-fé, que não tinham motivos para duvidar das informações de um registro imobiliário com força probante. ${ }^{391}$

O autor ressaltava que, para utilizar o elemento sistemático na interpretação, era necessário analisar todo o sistema do Código, como por exemplo, o fato dele sempre tutelar a boa-fé e de disciplinar distinções entre atos a título gratuito ou oneroso, o que demonstrava sua predisposição pelo sistema germânico da força probante do registro. ${ }^{392}$

Contrariando o entendimento de Fonseca, Gonçalves de Oliveira afirmava que se fosse utilizado o elemento sistemático para a interpretação dos dispositivos referentes à transmissão da propriedade imóvel, chegar-se-ia a uma conclusão totalmente diversa daquela indicada por este autor. Afinal, o simples fato de o ordenamento privado ter adotado postura de proteção à boa-fé, não autorizava a conclusão de que o sistema registral brasileiro consagrou o princípio da força probante aos moldes do código alemão. Na realidade, ao invés de aplicar o princípio da boa-fé (art. 106 e seguintes e parágrafo único do art. 968) nas transmissões de propriedade imóvel, o mais correto seria empregar os princípios que regulavam a tradição, já que para muitos civilistas a transcrição nada mais era do que a tradição solene. Assim sendo, a análise do art. 622 do Código Civil seria essencial: ${ }^{393}$

“Art. 622. Feita por quem não seja proprietário, a tradição não alheia a propriedade. Mas, se o adquirente estiver de boa-fé, e o alienante adquirir depois o domínio, considera-se revalidada a transferencia e operado o effeito da tradição, desde o momento do seu acto.

Parágrafo único. Também não transfere o domínio a tradição, quando tiver por título um acto nullo." 394

\footnotetext{
391 O registro immobiliário e sua força probante em face do Código Civil. Archivo Judiciário/Jornal do Commercio, Rio de Janeiro: Rodrigues \& C., 1937. p. 30/vol. XLII.

${ }^{392}$ Ibidem., p.31.

${ }^{393}$ Valor probante do registro de immoveis. Archivo Judiciário/Jornal do Commercio. Rio de Janeiro: Rodrigues \& CIA, 1939. p. 28/vol. LII.

${ }^{394}$ Lacerda, Paulo de. Codigo Civil Brasileiro. Rio de Janeiro: Jacintho Ribeiro dos Santos Editor, 1916. p. 188.
} 
OLIVEIRA acreditava que ao aplicar os princípios da tradição à transcrição, chegarse-ia ao entendimento de que o adquirente de boa-fé só adquiria a propriedade, depois que o alienante obtivesse o seu domínio e desde que não fosse por meio de título nulo. ${ }^{395}$

Compreendido o conceito do princípio da força probante e apresentados os principais argumentos de cada uma das correntes, parte-se agora para o estudo da fé pública que, sem dúvida, tem extrema relação com o princípio da presunção de domínio.

A fé pública geralmente é analisada sob dois aspectos. Primeiro, o de caráter formal, que nada mais é do que a fé publica que é concedida ao oficial ou tabelião, para que possam declarar a veracidade dos atos realizados no Registro ou Tabelionato. Segundo, o de caráter material, que consiste em um princípio registral, no qual o adquirente de boa-fé que confia nos dados registrais sempre é protegido. ${ }^{396}$ Esse último baseia-se na fé pública que o registro deve sempre proporcionar. ${ }^{397}$

Para aqueles juristas que defendiam que o princípio da presunção de domínio somente gerava efeitos no campo processual, não havia como o sistema registral brasileiro ter adotado o princípio da fé publica, uma vez que, independentemente das características do terceiro adquirente, ele só teria direito à ação reivindicatória quando prejudicado.

Para o outro grupo, o princípio da fé pública relacionava-se intrinsecamente com o da força probante, e também estava previsto no art. 859 do Código Civil, restando apenas verificar qual era a extensão da retificação permitida pelo dispositivo 860 .

Nos sistemas que adotam o princípio da fé pública, a existência de um cadastro imobiliário que apresente todas as características que envolvem o bem, permite que apenas em casos excepcionais haja necessidade de proteger o terceiro adquirente de boa-fé. Afinal, diminuem-se as possibilidades de que haja nos assentos informações diferentes das reais, dificultando a ocorrência de fraudes ou mesmo o engano do oficial. Como no sistema de

\footnotetext{
${ }^{395}$ Valor probante do registro de immoveis. Archivo Judiciário/Jornal do Commercio. Rio de Janeiro: Rodrigues \& CIA, 1939. p. 30/vol. LII.

${ }^{396}$ Carvalho, Afrânio. Registro de Imóveis. $3^{\text {a }}$ ed., Rio de Janeiro: Forense, 1982. p. 32.

${ }^{397}$ O princípio da fé pública também é chamado de princípio da publicidade material sob a forma da fé pública ou da proteção do comércio. Soriano De souza Neto, José. Publicidade Material do Registro Imobiliário: efeitos da transcrição. Recife: [s.n.], 1940. p. 56.
} 
registro brasileiro houve a previsão de um registro predial, mas não de um cadastro da propriedade imóvel, pareceu difícil aproximá-lo do regime germânico, já que um de seus princípios característicos, o da fé pública, dependia da individualização total do imóvel, tanto em seu aspecto subjetivo (qualificação dos titulares) quanto objetivo (descrição do bem).

Para Augusto César, se o legislador desejasse proteger o terceiro de boa-fé em detrimento do real proprietário, deveria trazer um dispositivo expresso sobre a matéria. Não o tendo feito, a interpretação deveria ser de acordo com o art. 860 do Código e com os princípios gerais. $^{398}$

Já Soriano Neto entendia que nem mesmo os autores do Código Civil desejavam adotar o princípio da fé pública. ${ }^{399}$ Para ele a cópia do artigo 891 do Código Alemão parecia ter sido feita "inscientemente" pelos legisladores brasileiros, já que estes não deram sustentação formal ao dispositivo, nem reproduziram outros artigos que se harmonizavam perfeitamente com ele. De modo isolado, o artigo não conseguia atingir o sentido que muitos autores queriam atribuir-lhe, ou seja, de tornar preponderante as informações do registro em relação a terceiros de boa-fé. ${ }^{400}$

\footnotetext{
${ }^{398}$ Sobre o Registro de Imóveis. Revista da Faculdade de Direito de São Paulo, São Paulo, n. 31, p.427, set 1935. Nesse mesmo sentido BuENo para quem "Pretender ampliar a compreensão do texto é forçar a realidade. Pretender inferir apenas das discussões que caldearam o Código, que o princípio da fé pública foi nele introduzido, é esquecer que o elemento histórico não merece grande relevo na interpretação do direito, é examina-lo inexatamente, expandir dois erros até o ponto de corromper a própria lei”. Effeitos da transcripção no regime do Código Civil Brasileiro. São Paulo: Revista dos Tribunais, 1941. p. 31.

${ }^{399}$ Ficou conhecida na doutrina civilista nacional as discussões realizadas por meio de obras jurídicas entre Lysippo Garcia, Philadelpho Azevedo e Soriano Neto (mais especificamente entre estes dois últimos) acerca da aproximação do sistema registrário brasileiro ao germânico e, principalmente, sobre a possível previsão do princípio da fé pública. Os dois primeiros juristas defendiam a adoção do princípio da fé pública pelo Código Civil de 1916, o que foi totalmente criticado por Soriano Neto. O debate ocorreu da seguinte forma: Lysippo Garcia publicou sua obra $O$ Registro de Imóveis: a transcrição em 1922. Dois anos mais tarde Philadelpho Azevedo em uma breve análise sobre a lei de registros públicos, afirmou expressamente ter se filiado à doutrina de Garcia. Quase 20 anos depois, em 1940, Soriano Neto publicou o livro titulado Publicidade Material do Registro Imobiliário: efeitos da transcrição, no qual criticou fortemente as opiniões dos dois autores, chegando a afirmar que o erro na interpretação do dispositivo do Código Civil de 1916 derivava do desconhecimento do sistema imobiliário alemão, que os juristas não procuraram estudar. Diante do embate expresso, Philadepho Azevedo escreveu outra obra, Registro de Imóveis (Valor da Transcrição), no qual reafirma a aplicação no Brasil do princípio da fé pública, até mesmo por uma necessidade social, não importando se tenha sido extraído ou não do sistema alemão. Nestas duas obras a discussão é intensa, parecendo muitas vezes haver um acirrado diálogo entre elas (todas as obras constam na bibliografia desta dissertação).

${ }^{400}$ Soriano de souza Neto, José. Publicidade Material do Registro Imobiliário: efeitos da transcrição. Recife: [s.n.],1940. p. 56.
} 
OLIVEIRA também entendia que o ordenamento brasileiro não havia protegido o terceiro adquirente de boa-fé. Para o autor, isso ficava claro com a análise do parágrafo único do art. 968 do Código Civil, combinado com o art. 524. ${ }^{401}$ Estes dispunham:

“Art. 524. A lei assegura ao proprietario o direito de usar, gozar e dispor de seus bens e de rehavel-os do poder de quem quer que injustamente os possua". ${ }^{402}$

“Art. 968. Se, aquelle que indevidamente recebeu um immovel, o tiver alienado em boa-fé, por titulo oneroso, responde sómente pelo preço recebido; mas, se dobrou de má-fé, além do valor do immovel, responde por perdas e danos.

Parágrafo único. Se o immóvel se alheou por titulo gratuito, ou se, alheando-se por titulo oneroso, obrou de má-fé o terceiro adquirente, cabe o que pagou por erro o direito de reivindicação". ${ }^{403}$

Analisando o parágrafo único do artigo 968, autor afirmava que, se o Código realmente desejasse defender aquele adquirente de boa-fé a título oneroso contra quaisquer reivindicantes, esse dispositivo consistiria em uma exceção a regra geral consagrada no art. 524 do Código Civil que previa a possibilidade do proprietário reivindicar seus bens. Ademais, se essa exceção fosse aplicada a todos os atos onerosos e não só aos casos de pagamento indevido, deveria vir prevista na Parte Geral do Código ou nas disposições gerais do contrato e não no capítulo em que era disposta. Por fim, ressaltava que o preceito do parágrafo único do art. 968, também estava presente no direito francês, em plena conformidade com o sistema registral ali adotado, não sendo característico do regime que aplicava o princípio da fé pública. ${ }^{404}$

Otávio Moreira Guimarães reiterava o entendimento do grupo ao afirmar que, no direito brasileiro, era o negócio jurídico que se transcrevia, ou seja, o registro era um requisito constitutivo do ato. Dessa maneira, não era compreensível que, anulado um ato, a transcrição que era "uma de suas parcelas integrantes" continuasse válida. ${ }^{405}$

\footnotetext{
${ }^{401}$ Valor probante do registro de immoveis. Archivo Judiciário/ Jornal do Commercio. Rio de Janeiro: Rodrigues \& CIA, 1939. p. 38/vol. LII.

${ }^{402}$ LaCERDA, Paulo de. Codigo Civil Brasileiro. Rio de Janeiro: Jacintho Ribeiro dos Santos Editor, 1916. p. 169.

${ }^{403}$ Ibidem., p. 246.

${ }^{404}$ Oliveira, Gonçalves de. Valor probante do registro de immoveis. Archivo Judiciário/Jornal do Commercio. Rio de Janeiro: Rodrigues \& CIA, 1939. p. 28/ vol. LII.

${ }^{405}$ Comentário a acórdão do Tribunal de Apelação de S. Paulo. Revista dos Tribunais, São Paulo, vol. CXXXIII, ano XXX, n.496, p. 198, set. 1941.
} 
Seguindo doutrina contrária, FonSECA defendia que o ordenamento deveria proteger o terceiro adquirente de boa-fé, a título oneroso. Segundo o autor, o tratamento deveria ser mais rigoroso quando se tratasse de ato a título gratuito, pelo fato de que "quem procura evitar um prejuízo deve ter preferência sobre aquelle que pretende obter lucro". Assim, apenas a transcrição em favor de terceiro de boa-fé, que adquirisse a título oneroso de quem não era dono, produziria efeitos. Quando a título gratuito, o adquirente se igualava-se àquele de má-fé, devendo a propriedade continuar a pertencer ao real proprietário não inscrito, a fim de que o adquirente não obtivesse lucro injustamente. ${ }^{406}$

No mesmo sentido Serra Lopes afirmava que, pelo Código Civil, o contratante a título gratuito ou de má-fé, que adquirisse de proprietário não inscrito, ficava exposto às reivindicações do bem. ${ }^{407}$

Segundo o entendimento de Philadelpho Azevedo, deixar o adquirente de boa-fé a título oneroso protegido de qualquer contestação futura, mesmo por quem demonstrasse melhor direito, era medida realizada em benefício dos interesses nacionais, ou seja, da segurança das transações comerciais e do crédito. Para o autor, não importava se o sistema registral brasileiro tinha ou não sofrido na origem a "pura inspiração germânica"; o fundamental era que se extraísse do regime o que interessasse às necessidades brasileiras, e o princípio da fé pública interessava. ${ }^{408}$

Como esses autores diferenciavam os casos de aquisição a título oneroso e a título gratuito, torna-se difícil afirmar que eles defendiam a presença do princípio da fé pública no sistema registral brasileiro, aos moldes do sistema alemão, uma vez que neste a proteção do ordenamento ocorria a todo terceiro de boa-fé. Ou seja, para o direito alemão apenas não seria justo acobertar o adquirente de má-fé, que sabia do erro no livro fundiário ou mesmo que havia fraudado o assento.

Contrapondo-se justamente à proteção do adquirente de boa-fé, GuIMARÃES afirmava que ela só poderia prevalecer se o terceiro errasse "excusadamente". Assim, se ele

${ }^{406}$ O registro immobiliário e sua força probante em face do Código Civil. Archivo Judiciário/Jornal do Commercio. Rio de Janeiro: Rodrigues \& C., 1937, p. 31/vol. XLII.

${ }^{407}$ Tratado de Registros Públicos. Rio de Janeiro: Jacintho Ribeiro dos Santos, 1938. p. 44/vol.I.

${ }^{408}$ Registro de Imóveis (Valor da Transcrição). Rio de Janeiro: Jacintho Editora, 1942. p. 5 a 9. 
soubesse que o registro no direito brasileiro não convalidava ato nulo, nem atribuía propriedade a quem não era proprietário, ele nunca poderia dizer que estava de boa-fé, já que errava com culpa. ${ }^{409}$

Anos mais tarde, Silvio Rodrigues corroborou esse entendimento, ao sustentar que aquele que adquirisse um bem deveria ter consciência de que o fato do alienante estar inscrito nos livros registrais, não garantia total segurança a sua aquisição. Dessa maneira, para assegurar seu direito de propriedade, o terceiro adquirente deveria prevenir-se de títulos que garantissem um futuro reconhecimento do usucapião. ${ }^{410}$

Para Bueno, se a interpretação dos autores que defendiam a proteção do adquirente de boa-fé a título oneroso estivesse correta, haveria uma série de conseqüências que não estavam previstas no Código Civil. Por exemplo, no caso da fraude contra credores proteger o terceiro de boa-fé mantendo o imóvel em seu nome, prejudicaria o credor e diminuiria a segurança do crédito. Já na hipótese do real proprietário não se manifestar quanto à alienação de seu bem, permitir que o domínio ficasse com o terceiro adquirente de boa-fé era fazer com que o indivíduo perdesse seu direito real sem contribuir para isso ${ }^{411}$, ou seja, seria um caso de perda da propriedade sem previsão expressa na lei.

Dessa forma, autor entendia que se a intenção do legislador brasileiro fosse adotar o princípio da fé pública, outras medidas deveriam ter sido tomadas para evitar que situações de flagrante injustiça não ficassem descobertas. Como exemplo, seria importante que o Código Civil trouxesse princípios mais extensos no relativo à fraude contra credores e ao pagamento indevido. $^{412}$

Ademais, para BuENo, o argumento da existência no sistema registral do princípio da fé pública ficava comprometido, quando se analisavam outros dispositivos do Código Civil,

\footnotetext{
${ }^{409} \mathrm{O}$ autor completava " $\mathrm{O}$ terceiro adquirente, devendo conhecer a finalidade do registro na lei brasileira, nunca poderá alegar ainda a ignorância da certeza do seu direito". A Boa-Fé no Direito Civil Brasileiro. São Paulo: Emprêsa Gráfica da "Revista dos Tribunais", 1938. p. 52 e 53.

${ }^{410}$ Exemplificando o afirmado, Silvio ROdrigues escreveu "Com efeito, é correntio no Brasil o comprador exigir do vendedor a certidão vintenária do domínio. Pois, se mais tarde aparecer um reivindicante, a ele será oposta não só a defesa fundada nos títulos do alienante, como também baseada na exceção de usucapião". Rodrigues, Sílvio. Registro de Imóveis In: FrançA, R. Limongi (coord.). Enciclopédia Saraiva do Direito. São Paulo: Saraiva, 1977. p. 276/vol.64.

${ }^{411}$ Effeitos da transcripção no regime do Código Civil Brasileiro. São Paulo: Revista dos Tribunais, 1941.p.34.

${ }^{412}$ Ibidem., mesma página.
} 
como aqueles referentes ao usucapião e a evicção, e outras figuras jurídicas vigentes como o Registro Torrens. ${ }^{413}$

O autor justificava a assertiva dizendo que o princípio da fé pública era incompatível com o usucapião ordinário previsto no art. 551 do Código Civil. Se apenas com a transcrição (justo título) e a boa-fé do adquirente o imóvel fosse transmitido, como previa o princípio da fé pública, não haveria razão para o dispositivo acima citado exigir ainda o prazo de 10 anos de posse para presentes e de 20 anos para ausentes. ${ }^{414}$

Fonseca discordava da posição de BuENo, afirmando que o usucapião ordinário apenas não seria aplicado nos casos em que houvesse transcrição regular de título oneroso por terceiro adquirente de boa-fé. Para as demais situações, como no caso de aquisição a título gratuito, ou quando o titulo anterior não fosse registrado, caberia o instituto. ${ }^{415}$

Oliveira criticava o entendimento de Fonseca dizendo que o autor contradizia-se. Afinal, se o adquirente de imóvel a titulo gratuito devia ser sempre comparado ao adquirente de má-fé, pois a presunção de má fé era absoluta, ele jamais poderia fazer uso do usucapião ordinário, já que faltaria o requisito da boa-fé. Ademais, Oliveira compreendia que só existia justo título quando este fosse transcrito; logo, seria inconcebível a possibilidade de prescrição aquisitiva ordinária nas hipóteses de título não registrado. 416417

Philadelpho Azevedo explicava a situação do adquirente a título gratuito afirmando que ele não estava sujeito a uma presunção absoluta de malícia, mas sim que era tratado de maneira mais rigorosa pelo ordenamento. Assim, em alguns casos, era possível que se utilizasse o instituto do usucapião. ${ }^{418}$

\footnotetext{
${ }^{413}$ Effeitos da transcripção no regime do Código Civil Brasileiro. São Paulo: Revista dos Tribunais, 1941.p. 34.

${ }^{414}$ Ibidem., mesma página.

415 O registro immobiliário e sua força probante em face do Código Civil. Archivo Judiciário/Jornal do Commercio. Rio de Janeiro: Rodrigues \& C., 1937. p. 31/vol. XLII.

${ }^{416}$ Oliveira, Gonçalves de. Valor probante do registro de immoveis. Archivo Judiciário/Jornal do Commercio. Rio de Janeiro: Rodrigues \& CIA, 1939. p. 28/vol. LII.

${ }^{417}$ Diferentemente de BuENo que mostra a incompatibilidade do usucapião ordinário com o princípio da fé pública, OLIVEIRA busca provar como são inconciliáveis a prescrição aquisitiva ordinária e o princípio germânico da força probante. Ibidem., p. 29.

${ }^{418}$ Registro de Imóveis (Valor da Transcrição). Rio de Janeiro: Jacintho Editora, 1942. p. 83.
} 
Para Azevedo, a prescrição aquisitiva também era invocada nas relações entre as próprias partes, quando envolvesse caso de má-fé e aquisição por título gratuito. Acreditava que, o instituto do usucapião seria útil nas hipóteses de insegurança na caracterização do título, ou seja, quando o imóvel não tivesse limites determinados e individuação precisa. ${ }^{419}$

Já no relativo à evicção, o art. 1.117, II do Código Civil ${ }^{420}$ dispunha que ela apenas era possível quando aquele que a pleiteava não soubesse que a coisa adquirida era alheia ou litigiosa. Sendo assim, só a pessoa de boa-fé podia fazê-lo. Mas, como pelo princípio da fé pública o adquirente de boa-fé tornava-se proprietário, ele nunca iria demandar pela evicção, o que para BuENo esvaziava o sentido dessa figura jurídica. ${ }^{421}$

Segundo Oliveira, o dispositivo do Código Civil referente à evicção demonstrava que a boa-fé do adquirente não o protegia diante de possíveis reivindicações. ${ }^{422}$

Já Philadelpho Azevedo entendia que a evicção era necessária mesmo em um ordenamento em que vigorava o princípio da fé pública registral, porque apesar de todas as precauções, o assento poderia falhar "por uma controvérsia de fato, imprecisão de limites, duplo registro, etc" devendo-se nestes casos se recorrer ao instituto. ${ }^{423}$

Segundo o autor, a presença no ordenamento de institutos incompatíveis com um "sistema de absoluto rigor da propriedade" decorria da existência de circunstâncias de fato,

que impediam um sistema ideal. Assim, essas figuras funcionavam como "válvulas de segurança". ${ }^{424}$

No entanto, essa não era a opinião de BuEno, que acreditava que a incompatibilidade entre o princípio da fé pública e o usucapião ordinário e a evicção,

\footnotetext{
${ }^{419}$ Registros Públicos. Lei n. 4.827 de 7 de fevereiro de 1924 (commentario e desenvolvimento). Rio de Janeiro: Litho- Tupo Fluminense (S.A), 1924, p. 104.

420 “Art. 1.117. Não pode o adquirente demandar pela evicção:

II - Se sabia que a coisa era alheia ou litigiosa". Lacerda, Paulo de. Codigo Civil Brasileiro. Rio de Janeiro: Jacintho Ribeiro dos Santos Editor, 1916. p. 266.

${ }^{421}$ Bueno, Fernando Euler. Effeitos da transcripção no regime do Código Civil Brasileiro. São Paulo: Revista dos Tribunais, 1941.p. 34.

${ }^{422}$ Valor probante do registro de immoveis. Archivo Judiciário/Jornal do Commercio. Rio de Janeiro: Rodrigues \& CIA, 1939. p. 29/vol. LII.

${ }^{423}$ Registro de Imóveis (Valor da Transcrição). Rio de Janeiro: Jacintho Editora, 1942. p. 82 e 83.

${ }^{424}$ Ibidem., p. 83.
} 
demonstravam o porquê do legislador alemão não ter previsto aquele instituto, e ter limitado o uso deste aos bens móveis. ${ }^{425}$

Discordava dessa interpretação Philadelpho Azevedo, para quem o Código Civil Alemão tinha previsto duas hipóteses de usucapião que poderiam ser, sem qualquer objeção, comparados ao usucapião ordinário e extraordinário previstos no ordenamento brasileiro. Ademais, havia também a previsão da figura da evicção, apesar de ser pouco aplicada em relação aos imóveis. ${ }^{426}$

No relativo ao Registro Torrens, a legislação brasileira previu, em 1890, e recordou com o Código Processual Civil, uma série de exigências para a inscrição do imóvel por este sistema, como a necessidade da participação de um juiz de direito e de um promotor de justiça, a publicação de editais pela imprensa e prazo nunca inferior a dois meses para manifestação dos interessados. Segundo Bueno, todas as medidas foram previstas para que, ao aplicar o princípio da fé pública, a garantia de segurança do comércio não prejudicasse a segurança da propriedade ${ }^{427}$, cautela inexistente no registro comum.

Não há como negar a pertinência do último entendimento de BuENO. Afinal, se um sistema paralelo de registro imobiliário (Torrens) tinha sido mantido e previa que várias providências deveriam ser tomadas para a aplicação do princípio da fé pública, fícava difícil imaginar que existia, no mesmo ordenamento jurídico, outro sistema registrário com características similares ao Torrens, porém sem nenhuma de suas exigências e precauções.

Perceba que o estudo das discussões acerca da previsão pelo Código Civil de 1916 do princípio da força probante absoluta e da fé pública é extremamente pertinente para o objeto desta pesquisa. Entender que o sistema registrário brasileiro seguiu os ensinamentos germânicos é concluir pela opção legislativa de priorizar a segurança do comércio em detrimento da segurança do direito de propriedade. Afinal, o adquirente de boa-fé sempre estará protegido e o real proprietário ficará em alguns casos descoberto, restando-lhe apenas uma indenização com base no enriquecimento sem causa. A inexistência de cadastro

\footnotetext{
${ }^{425}$ Effeitos da transcripção no regime do Código Civil Brasileiro. São Paulo: Revista dos Tribunais, 1941.p. 35.

${ }^{426}$ Registro de Imóveis (Valor da Transcrição). Rio de Janeiro: Jacintho Editora, 1942. p. 83 e 84.

${ }^{427}$ Effeitos da transcripção no regime do Código Civil Brasileiro. São Paulo: Revista dos Tribunais, 1941. p.35.
} 
imobiliário e a confusão de dimensões e divisas da propriedade imóvel no Brasil fariam com que fosse corrente a escolha em garantir o direito do adquirente de boa fé. Difere assim, do que afirmava Soriano Neto sobre o regime adotado na Alemanha, em que a precisão do cadastro, igualando a realidade jurídica à situação fática, permitia que as duas seguranças estivessem presentes ao mesmo tempo. ${ }^{428}$

Além disso, ao beneficiar o comércio honesto, a previsão dos dois princípios como previstos no Código Alemão, contribuiu para fornecer garantia ao credor que inscrevera seu direito nos livros registrais, confiando em suas informações.

Quando se nega ao ordenamento brasileiro a presença dos princípios da força probante alemã e da fé pública, prioriza-se o direito do proprietário que, por erro do oficial ou fraude, não esteja inscrito nos assentos registrários. Assim, ele tem assegurado que jamais perderá a propriedade imóvel se não for de sua vontade (ou seja, por meio de alienação, renúncia, abandono) ou ainda, se reivindicar a tempo o bem que esteja sob a posse de pessoa que requeira seu usucapião.

Após a análise de todos os argumentos apresentados por cada uma das correntes, tanto no referente ao princípio da força probante, quanto ao da fé pública, chega-se à conclusão de que o ordenamento brasileiro criou um sistema imobiliário distinto do germânico. Assim, a presunção relativa de domínio tinha aspecto meramente processual e o princípio da fé pública não foi previsto. Afinal, defender a aplicação à moda alemã, significa priorizar a segurança do comércio em detrimento da segurança do direito de propriedade, sem que o sistema tenha previsto um arcabouço para sua sustentação, como seria, por exemplo, a obrigatoriedade de cadastro de todas as propriedades, entre outras providências.

Ademais, esse posicionamento justifica-se na medida em que a transcrição apenas transfere ao adquirente o direito que o alienante possui. Se este não possui direito algum sobre o imóvel, não há o que transmitir.

Em suma, em um país em que não existe perfeita correspondência entre as informações existentes no assento registral e a situação real dos imóveis, não há como

${ }^{428}$ Publicidade Material do Registro Imobiliário: efeitos da transcrição. Recife: [s.n.], 1940. p. 9. 
conciliar a segurança do direito de propriedade e do comércio, tornando-se fundamental a escolha pela preponderância de uma delas.

Depois de analisados os principais dispositivos do Código Civil de 1916, relativos à transmissão da propriedade imóvel pelo registro do título, destaca-se o que ainda ocorreu com a matéria até o final da Primeira República.

\subsection{Primeiros anos de vigência do Código Civil: correções e complementações}

Como foi visto no item anterior, os legisladores do Código Civil de 1916 regularam o sistema ordinário de registro de imóveis. Em nenhum de seus dispositivos, mencionou-se a manutenção no ordenamento do sistema Torrens, o que gerou questionamentos quanto à possibilidade de sua aplicação.

Para Soriano Neto, o Código Civil não tratou do Registro Torrens, porque os artigos do Projeto, que incluíam entre os atos de transferência do bem imóvel os endossos dos títulos translativos da propriedade cadastrada, instituto característico do sistema de origem australiana, foram rejeitados pela Câmara. ${ }^{429}$

Mas, em 31 de dezembro de 1917, a lei federal n. 3446, que orçava a Receita Geral da República dos Estados Unidos do Brasil para o exercício de 1918, reafirmou a existência do Registro Torrens ao arrolar como fonte da receita federal as quantias obtidas com as contribuições para o sistema. ${ }^{430}$

Para Spencer Vampré, a declaração pela Lei Orçamentária de que o Registro Torrens continuava em vigor, ultrapassava suas atribuições legislativas. Segundo o autor, apenas o Poder Judiciário poderia determinar se um instituto permanecia ou não no ordenamento jurídico, já que era sua a tarefa de interpretar as leis. Assim, a Lei Orçamentária só poderia criar direito novo, não sendo de sua competência interpretar regras jurídicas. ${ }^{431}$

\footnotetext{
${ }^{429}$ Publicidade Material do Registro Imobiliário: efeitos da transcrição. Recife: [s.n.], 1940. p. 105.

${ }^{430}$ A lei previa "Fundo de garantia do registro Torrens: importancia das porcentagens e multas a que se referem os arts. 60 e 61 do decreto $451-\mathrm{B}$, de 31 de maio de 1890, que está e continúa em vigor...\$”

${ }^{431}$ Pareceres e Razões. Registro Torrens - Sua Inconstitucionalidade. Revista Forense, [s.1.], vol. 39, p. 340, 1922.
} 
VAMPRÉ ainda entendia que o próprio decreto do Governo Provisório, que criou o Registro Torrens era inconstitucional, uma vez que sem que houvesse qualquer indenização prévia ou declaração pelo Poder Público, um imóvel pela simples matrícula passava para a titularidade daquele que o inscreveu, sendo impedida qualquer ação de reivindicação. ${ }^{432}$

Como a crítica de VAMPRÉ ao sistema Torrens atingia diretamente a presunção absoluta fornecida pela lei a um registro imobiliário, sua posição acabou sendo combatida pelos defensores do princípio da força probante absoluta. Destaca-se entre eles Philadelpho AzEvedo, para quem o sistema da força probante atribuído ao registro era o mesmo encontrado nos títulos de crédito e no usucapião. Dessa forma, como o direito de propriedade não poderia ser garantido a duas pessoas ao mesmo tempo, o ordenamento protegia aquele que o havia adquirido regularmente. ${ }^{433}$

Apesar das discussões doutrinárias, o Registro Torrens continuou a ser empregado no Brasil. $^{434}$

Em 18 de setembro de 1939, a aplicação do Registro Torrens no direito privado brasileiro foi confirmada com a promulgação do Código de Processo Civil, que restringiu o instituto aos imóveis rurais e previu o procedimento para o registro (arts. 457 a 464 ).

Dessa forma, a partir de 1939, a matéria de direito substancial continuou regulada pelos diplomas de 1890 e o aspecto processual passou a ser regido pelo Código de Processo Civil. ${ }^{435}$ A grande inovação foi a restrição ao uso do sistema Torrens apenas aos imóveis rurais, porém, mantinha-se o caráter facultativo.

Para Philadelpho Azevedo, a limitação do Registro Torrens aos imóveis rurais, com a exclusão expressa pela lei dos urbanos, simbolizava a tendência de restrição do sistema. ${ }^{436}$

\footnotetext{
${ }^{432}$ Ibidem., mesma página.

${ }^{433}$ Registros Públicos. Lei n. 4.827 de 7 de fevereiro de 1924 (commentario e desenvolvimento). Rio de Janeiro: Litho- Tupo Fluminense (S.A), 1924, p. 105.

${ }^{434}$ Philadelpho Azevedo afirmava que uma das grandes adeptas do sistema Torrens foram as companhias de mineração que buscavam evitar litígios sobre a área de exploração. Registro de Imóveis (Valor da Transcrição). Rio de Janeiro: Jacintho Editora, 1942. p. 85 e 88.

${ }^{435}$ Assis, Jacy de. Do Registro Torrens. Revista dos Tribunais, São Paulo, vol. 371, ano 55, p. 20 e 21, [s.d.]

${ }^{436}$ Registro de Imóveis (Valor da Transcrição). Rio de Janeiro: Jacintho Editora, 1942. p. 88.
} 
Porém para que esse sistema registral fosse aos poucos eliminado da ordem jurídica, a simples redução dos imóveis sujeitos ao Registro Torrens não era suficiente. Segundo o autor, não havia motivos para insistir na implantação de um regime que tinha defeitos inerentes a "toda organização fragmentária", baseado não em um cadastro da propriedade, mas sim em plantas e memoriais apresentados pelos próprios interessados, submetidos a um controle incipiente, feito principalmente pelos vizinhos, que poderiam impugnar ou não o registro. Philadelpho Azevedo concluía que o ideal era aprimorar o sistema comum, que era mais fácil e econômico. ${ }^{437}$

Segundo Waldemar Loureiro, os legisladores do Código de Processo Civil erraram ao dispor sobre um sistema "caduco", inadequado ao regime imobiliário brasileiro. O sistema registral comum, ao exigir o arquivamento da planta topográfica do imóvel e o registro do título do transmitente ${ }^{438}$, retirava a utilidade do sistema Torrens. ${ }^{439}$

Também criticando a previsão do Registro Torrens, Luiz Polli afirmava que ele era incompatível com o Código Civil e inconstitucional. Era incompatível porque o Código Civil já regulava todos os modos de aquisição e não citava o sistema australiano. Era inconstitucional porque por um simples processo de registro o título de propriedade tornava-se inatacável (mesma opinião de VAMPRÉ). Como tornar a titularidade inquestionável era a principal finalidade do sistema, sua exclusão levaria o Registro Torrens a não mais se distinguir daquele previsto no Código Civil. ${ }^{440}$

Já Soriano Neto entendia que a manutenção do Registro Torrens no ordenamento brasileiro era importante, por ser o sistema que melhor garantia segurança e estabilidade ao comércio imobiliário. Ademais, poderia ser efetivamente implantado naqueles locais em que por suas características seria fácil a elaboração de um cadastro. ${ }^{441}$

\footnotetext{
${ }^{437}$ Ibidem., p. 88 e 89.

${ }^{438}$ Inovação do decreto n. 18.542 de 1928, que será estudado em seguida.

${ }^{439}$ Registro da Propriedade Imóvel. $6^{\mathrm{a}}$ ed. Rio de Janeiro: Revista Forense, 1968. p. 22/vol.I.

${ }^{440}$ Luiz Polli expressou sua posição em Parecer elaborado ao Conselho da Ordem dos Advogados, Seção do Estado da Guanabara, quando a projeto de lei, elaborado pelo deputado federal Celestino Filho, foi apresentado a Câmara dos Deputados em 5 de maio de 1965 propondo a extensão do Registro Torrens de maneira facultativa também aos imóveis urbanos. In: Loureiro, Waldemar. Registro da Propriedade Imóvel. 6 aed., Rio de Janeiro: Revista Forense, 1968. p. 24 a 28/vol.I.

${ }^{441}$ Como exemplo de área de fácil aplicação do regime, o autor cita a região cacaueira no sul da Bahia, onde quase todas as propriedades, antes de serem adquiridas do Estado pelos particulares, passaram por um processo de medição e demarcação, com elaboração de memorial descritivo e planta. Publicidade Material do Registro
} 
Apesar de não haver consenso quanto às vantagens e desvantagens do Registro Torrens, este continuou a ser aplicado.

Retornando-se ao sistema comum, a primeira complementação ao Código Civil ocorreu em 7 de fevereiro de 1924, com a publicação do decreto n. 4.827. A nova norma enumerou todos os registros públicos existentes (art. $1^{\circ}$ ), suas respectivas atribuições (arts. $2^{\circ}$ a $5^{\circ}$ ) e como seriam feitas as escolhas dos oficiais competentes (art. $6^{\circ}$ ) entre outras coisas, não trazendo nenhuma inovação à matéria objeto deste estudo.

Segundo FonSECA, o novo decreto reafirmou a proteção do ordenamento brasileiro ao terceiro adquirente de boa-fé, ao consolidar mais uma vez a adoção do princípio da fé pública. A confirmação estava no art. $5^{\circ}$, letra a, VIII que exigia a inscrição nos assentos prediais das citações para ações reais ou reipersecutórias. Esse dispositivo reafirmava a proteção ao adquirente de boa-fé na medida em que este jamais poderia ter seu direito atingido, caso a citação, que demonstraria a existência de litígio sobre o bem, não estivesse inscrita no momento em que ele adquirisse o imóvel. Para o autor, se essa não fosse a interpretação a ser dada, a exigência da inscrição tornar-se-ia "formalidade ociosa". ${ }^{442}$

Quatro anos mais tarde, em 24 de dezembro de 1928, o sistema registral brasileiro foi aprimorado mais uma vez com a edição do decreto n. 18.542, que dispôs de maneira expressa sobre o princípio da continuidade. Previam os artigos:

“Art. 206. Si o immovel não estiver lançado em nome do outorgante o official exigirá a transcripção do titulo anterior, qualquer que seja a sua natureza, para manter a continuidade do registro"

“Art. 228. Em todas as escripturas e actos relativos a immoveis, os tabelliães e escrivães farão referencia ao registro anterior, seu numero e cartorio, bem como nas declarações de bens prestados em inventarios e nos autos de partilha"

“Art. 234. Em qualquer caso não se poderá fazer transcripção ou inscripção sem prévio registro do titulo anterior, salvo se este não estivesse obrigado a registro, segundo o direito então vigente de modo a assegurar a continuidade do registro de cada predio, entendendo-se por

Imobiliário: efeitos da transcrição. Recife: [s.n.], 1940. p. 107 e 108.

${ }^{442} O$ registro immobiliário e sua força probante em face do Código Civil. Archivo Judiciário/Jornal do Commercio, Rio de Janeiro: Rodrigues \& C., 1937. p. 31/ vol. XLII. 
disponibilidade a faculdade de registrar alienações ou onerações dependentes assim, da transcripção anterior"

Com a nova previsão, para se realizar a transcrição ou inscrição era necessário o prévio registro do título anterior. Em outros termos, somente aquele que constasse nos livros como proprietário, poderia alienar o bem ou sofrer restrições em seu direito real, o que restringia a entrada de títulos no registro de imóveis. A idéia era fazer constar no Registro Imobiliário da localidade do bem todo o seu histórico, garantindo maior segurança aos atos realizados, uma vez que o encadeamento de titularidade diminuía a possibilidade de aquisição de bem daquele que não fosse dono.

Não há como negar a importância do princípio para obtenção das almejadas seguranças do crédito, do direito de propriedade ou do comércio nas transmissões da propriedade imóvel. ${ }^{443}$

Segundo Afrânio de Carvalho, a formação de uma corrente sem falhas no registro dos títulos de domínio dificultava a ocorrência de fraudes que, por muito tempo, foram comuns no país, como por exemplo, a inclusão de imóveis alheios em inventários, com sua posterior partilha e introdução no comércio. A fraude levava a formação de uma cadeia registrária a non domino, paralela à verdadeira. Quando a duplicidade de transcrições era descoberta, juízes e tribunais eram chamados a resolver o conflito que, muitas vezes, já tinha envolvido várias pessoas de boa-fé. Assim, confiar nas informações existentes no registro imobiliário nem sempre significava segurança nas transmissões. ${ }^{444}$

Sem dúvida, os problemas tinham se amenizado com a exigência pelo Código Civil, da transcrição nos livros registrais dos atos judiciais e causa mortis, base para a previsão do princípio da continuidade de $1928 .^{445}$

\footnotetext{
${ }_{443}$ Para SeRPa Lopes, o princípio da continuidade é "uma das principais peças de segurança do registro imobiliário, um dispositivo moralizador, um anteparo contra possíveis fraudes à função do registro imobiliário, como meio de prova do domínio". Tratado de Registros Públicos. Rio de Janeiro: Jacintho Ribeiro dos Santos, 1938. p. 351/ vol.IV.

${ }^{444}$ Registro de Imóveis. $3^{\text {a }}$ ed., Rio de Janeiro: Forense, 1982. p. 307.

${ }^{445}$ Afrânio de CARvalho enumera as fraudes comuns antes da inclusão entre os títulos registráveis dos atos judiciais e da transmissão causa mortis. Afirma o autor, "Deixados soltos, os títulos de transmissão causa mortis e os atos judiciais prestavam-se a numerosas fraudes, que frustravam consideravelmente a utilidade do registro. Dentre essas fraudes, algumas tornaram-se relativamente comuns: a descrição de imóveis alheios em inventário e sua conseqüente partilha e lançamento no mundo dos negócios; a execução graciosa, por conluio entre o exeqüente e o executado, de imóvel não pertencente a este e a resultante arrematação em hasta pública; a divisão
} 
Para ORlando Gomes, com a ampliação dos atos sujeitos à transcrição, muitos autores passaram a extrair o princípio da continuidade dos artigos do Código Civil, sendo a previsão da Lei de 1928 apenas a consagração do que já era aplicado. ${ }^{446} 447$

Soriano Neto criticava a adoção do princípio, questionando qual era o significado que ele teria no sistema, ou a que ele daria continuidade, oficialmente, não havia qualquer começo. Em seguida, concluía que o princípio não tinha nenhum valor teórico ou prático. Teórico, porque o princípio da continuidade não tinha relação com o sistema em que foi empregado, era uma criação do modelo germânico. Prático, porque constituiria um entrave ao comércio jurídico sobre imóveis, já que não teria correspondência com as demais regras formais e materiais. ${ }^{448}$

Philadelpho Azevedo, que propôs aos legisladores brasileiros as inovações trazidas pelo decreto n. 18.542 de 1928, discordava nominalmente de Soriano Neto. Primeiramente, afirmava que o princípio da continuidade não havia sido importado do regime germânico, já que nesse o preceito não existia com caráter absoluto, uma vez que eram excluídas do registro certas transmissões. Em seguida, o autor enumerava uma série de países que, apesar de não terem o registro de imóveis ao molde alemão, adotavam o princípio da continuidade, sem que isso lhes trouxesse nenhum problema (como Chile, México, Peru, Portugal entre outros). ${ }^{449}$

O autor também afirmava que a adoção do princípio da continuidade seria uma maneira de evitar a duplicidade das transcrições sobre um mesmo imóvel, uma vez que o oficial sempre verificaria o registro anterior. Ainda, com a consolidação desse princípio, nada mais impediria a predominância do preceito da fé pública no sistema brasileiro. ${ }^{450}$

de imóvel alheio e a venda ulterior dos seus quinhões; a venda da totalidade de um imóvel pelo condômino, como o marido, que, fazendo-se passar por solteiro, burlava a legítima dos filhos, obrigados depois a promover a nulidade parcial da venda, enquanto o imóvel era passado adiante ou submetido a inscrição no registro Torrens; a usurpação de imóveis alheios na delimitação periférica do imóvel submetido a inscrição no registro Torrens". Registro de Imóveis. $3^{\mathrm{a}}$ ed., Rio de Janeiro: Forense, 1982. p. 307.

${ }^{446}$ A introdução do princípio da continuidade do registro. Revista de Direito Imobiliário, São Paulo, ${ }^{\circ} 1,1978, \mathrm{p}$. 12, [s.d.].

${ }^{447}$ SERPA Lopes era um dos autores que entendia que a obrigatoriedade em transcrever o título anterior antes do novo decorria do sistema registral instituído pelo Código Civil de 1916, sendo apenas repetido pelo decreto de 1928. Tratado de Registros Públicos. Rio de Janeiro: Jacintho Ribeiro dos Santos, 1938. p. 352 e 353/ vol.IV.

${ }^{448}$ Publicidade Material do Registro Imobiliário: efeitos da transcrição. Recife: [s.n.], 1940. p. 69 e 70.

${ }^{449}$ Registro de Imóveis (Valor da Transcrição). Rio de Janeiro: Jacintho Editora, 1942. p. 55 a 58.

${ }^{450}$ Ibidem., p. 71. 
Sem dúvida, o sistema registral adotado pelo Brasil não impedia de nenhuma forma a aplicação do princípio da continuidade. Tratava-se, unicamente, de incluir entre as funções do oficial, a análise não apenas do título novo, mas também do anterior. Assim, ele precisava verificar se o título antigo estava inscrito e se o proprietário do imóvel era o mesmo que figurava na nova negociação como alienante, o que permitiria a formação da cadeia registraria. O fato das transcrições serem feitas seguidamente no livro registral, não havendo uma folha para cada imóvel, dificultava a busca pelo título anterior, porém não impossibilitava o emprego do princípio.

Houve incertezas quanto à maneira como seria cumprido o princípio da continuidade, quando o título anterior derivasse de um ato judicial ou se referisse à transmissão causa mortis. Como antes do Código Civil esses atos não precisavam ser transcritos, aquele que adquirisse o bem de quem o havia comprado em hasta pública, por exemplo, tinha dificuldade em cumprir a exigência da lei, ou seja, provar que estava adquirindo de quem deveria estar inscrito.

Segundo Serpa Lopes, o problema deveria ser resolvido de acordo com o momento em que o título anterior tivesse sido elaborado. Se antes do Código Civil, ele não precisava ser transcrito, já que no momento de sua formação a legislação vigente não exigia seu registro. Se elaborado após a promulgação do Código Civil, sua transcrição era obrigatòria. ${ }^{451}$

O autor ressaltava uma outra possibilidade, quaNdo a exisTência do título anterior ara ignorada ou era imp/ssível obtê-lo (como exemplo, o título havia desaparecido ou sido destruído). Nessas hapóteses, caberia ao juiz decidir pela dispensa ou exigibilidade do título. A primeira medida do magistrado seria mandar o oficial pesquisar no Registro de Imóveis a existência de algum título sobre aquele imóvel, mesmo que remoto. Não encontrando nada a respeito, o juiz teria certeza de que a transcrição do título apresentado não feria nenhum direito existente no livro registral. Mas isso não era suficiente, não seria correto permitir que alguém se utilizasse dessa ausência para adquirir um bem imóvel. Por outro lado, admitir o registro apenas com a apresentação do título anterior ou prova de usucapião era um "rigorismo legal". A solução encontrada pelo autor era a de permitir o registro do novo título, desde que por meio

${ }^{451}$ Tratado de Registros Públicos. Rio de Janeiro: Jacintho Ribeiro dos Santos, 1938. p. 354 a 357/vol. IV. 
de pesquisa de elementos e circunstâncias fosse possível provar que o título realmente um dia existiu. $^{452}$

Afrânio de Carvalho discordava de Serpa Lopes apenas nesta última situação. Para ele, caso a existência do título anterior fosse ignorada ou fosse impossível obtê-lo, a transcrição só seria feita, se junto com o registro houvesse uma ação de usucapião. ${ }^{453}$

As questões suscitadas demonstram como a procura pelo aprimoramento do sistema registral no Brasil esbarrava na longa vigência de um regime incompleto, que muitas vezes impediu mudanças bruscas na legislação pertinente e gerou inúmeros litígios, onerando as transmissões e tornando o comércio de bens imóveis pouco dinâmico.

Além de prever o princípio da continuidade, o decreto de 1928 tentou aproximar o sistema de outro preceito. No seu artigo 237, enumerou os requisitos para o registro da transmissão da propriedade imóvel, incluindo mais uma exigência na especialização subjetiva. Pelo decreto n. 370 de 1890, que regulava o decreto n. 169-A do mesmo ano, no momento da transcrição deveriam constar no assento registral apenas os nomes e domicílios do adquirente e alienante. Com a nova norma, incluiu-se também a necessidade de determinar a profissão das partes, alteração ínfima perto do que almejava o sistema para a individualização dos contratantes e maior segurança nos assentos, mas que representou mais um passo para a implantação do princípio da especialidade subjetiva.

Para Philadelpho Azevedo, o decreto completou os artigos 859 e 860 do Código Civil, confirmando a proteção ao terceiro adquirente de boa-fé. Assim, os artigos $218^{454}$ e 267 455 previam processo contencioso para a retificação do assento registral, a qual só atingiria terceiros após sua inscrição. Ademais, o mesmo dispositivo 267 e o $265^{456}$ criaram

${ }^{452}$ Serpa Lopes, Miguel Maria de. Tratado de Registros Públicos. Rio de Janeiro: Jacintho Ribeiro dos Santos, 1938. p. 357 a 360/vol. IV.

${ }^{453}$ Registro de Imóveis. $3^{\text {a }}$ ed., Rio de Janeiro: Forense, 1982. p. 314.

454 “Art. 218. Si o teôr do registro não exprimir a verdade poderá o prejudicado reclamar a rectificação por meio de processo contencioso, que será inscripto. (Cod. Civ., art. 860.)"

455 "Art. 267. Inscriptas no livro 4, serão as acções reaes ou pessoaes reipersecutorias, inclusive possessorias, quando fôr o caso, e as de rectificação de registro, pelas certidões das citações com os mesmo requisitos do art. 265, no que fôr applicavel, averbando-se as decisões, recursos e seus effeitos e ficando desde logo considerados os bens como litigiosos para o effeito de apreciação da fraude de posteriores alienações. (Lei n. 4.827 cit., art. $5^{\circ}$, a, VII.)"

${ }^{456}$ Art. 265. Inscriptos no livro 4 serão as penhoras, arrestos e sequestros de immoveis, á vista das certidões do escrivão, declarando-se tambem o nome e categoria do juiz, o depositario, as partes e a natureza do processo. 
mecanismos para evitar fraude exigindo a inscrição de penhoras, ações reais e reipersecutórias. Dessa maneira, aquele que de boa-fé adquirisse um imóvel que não sofresse nenhuma dessas restrições, não poderia ser prejudicado. ${ }^{457}$

Porém, o autor afirmava que o maior argumento da opção do sistema registral brasileiro pelo princípio da fé pública decorria do art. $221^{458}$, que expressamente protegia os direitos adquiridos por terceiros de boa-fé e a título oneroso. Assim, concluía que o decreto de 1928 havia consagrado o sistema registral que o Brasil precisava. ${ }^{459}$

Destaca-se que o decreto de n. 4.827 de 1924 já exigia a inscrição das penhoras e das citações nas ações reais e reipersecutórias relativas a imóvel (art. 5, a, VII e VIII).

Perceba-se como a insistência dos autores que defendiam a adoção do princípio da fé pública em confirmar por meio da legislação a pertinência de seus entendimentos mostra como anos após a publicação do Código Civil, a questão continuava atual e ainda havia adeptos praticantes de cada uma das correntes. As decisões judiciais também eram vacilantes, ora se inclinando por uma ou outra interpretação.

A publicação do decreto n. 18.542 também suscitou dúvidas quanto à sua constitucionalidade. Alguns autores entenderam que a norma era inconstitucional, uma vez que apesar de ser um mero regulamento do Poder Executivo, tendo então como função apenas consolidar as disposições regulamentares já existentes (decreto legislativo n. 4.857 de 1824), criava novos requisitos às escrituras públicas e aos registros. ${ }^{460}$

\footnotetext{
Paragrapho único(...)"

${ }^{457}$ Azevedo, Philadelpho. Registro de Imóveis (Valor da Transcrição). Rio de Janeiro: Jacintho Editora, 1942. p. 78.

458 “Art. 221. Tambem o registro poderá der rectificado ou annullado pelas decisões contenciosas proferidas sobre fraude de credores, quer em aç̧ão directa, quer indirectamente. quando rejeitados embargos de terceiro senhor e possuidor em execução ou acção executiva, salvo os direitos adquiridos por estranhos de boa fé e a titulo oneroso."

${ }^{459}$ Azevedo, Philadelpho. Registro de Imóveis (Valor da Transcrição). Rio de Janeiro: Jacintho Editora, 1942. p. 78 e 80 .

${ }^{460}$ Nesse sentido, JaIR Lins. Razões e Pareceres. Revista Forense, Rio de Janeiro, vol. 55, p. 166, 1930 e Francisco de Meira. Pareceres. Revista Forense, Rio de Janeiro, vol. 78, p. 484, [s.d.]. Este autor também entendia que caso o decreto fosse considerado constitucional, ele jamais poderia ser aplicado a instrumentos jurídicos anteriores à sua vigência.
} 
Esse não era o entendimento de Altino Antoine de Oliveira para quem “consolidar" não era apenas reunir leis esparsas, mas sim "consubstanciar princípios", ou seja, cristalizar preceitos já existentes no ordenamento. A Lei de 1928 não inovava ao exigir que o direito pertencesse ao alienante e que a continuidade registral fosse mantida, já que estas disposições nada mais eram do que imposições legais já em vigor. Afirmar o contrário seria dizer que o direito poderia ser transmitido de quem o não tivesse, ou que o registro exigia presunção de veracidade daquilo que não sabia ser verdade. ${ }^{461}$

Sendo ou não o decreto constitucional, a verdade é que ele foi aplicado, ora porque o Código Civil já exigia a inscrição de todos os atos de transmissão da propriedade imóvel, inclusive os judiciais e causa mortis, ora porque alguns anos mais tarde a Lei de Registros Públicos de 1939 repetiu suas determinações.

Por fim, é interessante perceber que o surgimento de legislações, disciplinando artigos do Código Civil poucos anos após a sua publicação, demonstra que o diploma serviu, no que se refere à transmissão da propriedade imóvel pelo registro do título, apenas como uma diretriz daquilo que deveria ser regulado na matéria. No entanto, era uma diretriz pouco esclarecedora, já que surgiram correntes interpretativas diversas, questionando o cerne do sistema o que, indubitavelmente, tornou a aplicação dos dispositivos extremamente nebulosa.

${ }^{461}$ Registro de Immoveis. Comprehensão, execução e melhoramentos. Jacutinga: [s.n.], 1938. p. 62. 


\section{SEGURANÇA JURÍDICA DO DIREITO DE PROPRIEDADE: A BUSCA PELA CORRESPONDÊNCIA ENTRE A REALIDADE FÁTICA E A REALIDADE JURÍDICA (ASSENTO REGISTRAL)}

\subsection{Contexto histórico}

Esta contextualização inicia-se com uma árdua tarefa, a de apontar as principais características de mais de 70 anos de um período complexo da história brasileira (1930 a 2004). A concentração de um lapso temporal extenso e de uma época pouco homogênea em um único capítulo não foi por acaso. Em todos esses anos, a única mudança significativa sofrida pelo objeto deste estudo decorreu de duas iniciativas legislativas que se completam, a 
lei n. 6.015 de 1973 (Lei de Registros Públicos) e a lei n. 10.406 de 2002 (Novo Código Civil).

Assim, não havia como cingir o capítulo, que acabou por envolver períodos distintos da história do Brasil, como a ditadura varguista, o período militar e a democratização.

O problema da longa época histórica a ser abordada foi solucionado, mantendo-se a mesma linha dos outros capítulos. Desde o início da dissertação, os contextos históricos foram construídos apenas com os principais aspectos que, de alguma maneira, influenciaram a questão da terra, no que se refere à regulamentação de sua transferência inter vivos como necessário instrumento para garantir segurança do crédito, do direito de propriedade e do comércio. Agora não será diferente.

Para começar a contextualização histórica, é fundamental que se indique a maneira pela qual os estudiosos vêm dividindo o período. Para Adriana Lopez e Carlos Guilherme Мота о período a partir de 1930, denominado de Era Getuliana é englobando por três etapas distintas: a República Nova (1930 a 1937), a ditadura do Estado Novo (1937 a 1945) e a República Populista e a República Patriarcal (1946 a 1964). Em seguida, há a República civilmilitar (1964 a 1985) e, por fim, a República autocrático-burguesa (1985 em diante). ${ }^{462}$

Durante grande parte desses períodos, a preocupação em disciplinar e aprimorar a transferência da propriedade imóvel não mais decorria unicamente dos interesses de uma elite agrário-exportadora. A composição da sociedade já vinha sofrendo modificações desde o final da Primeira Guerra Mundial. A impossibilidade de adquirir produtos importados durante o conflito, levou o país a acumular capital, utilizado anos mais tarde na aquisição de bens (como por exemplo, máquinas para suas futuras fábricas). Ao utilizar o dinheiro acumulado durante a guerra e o obtido com as exportações de café na compra de bens de capital, o Brasil começou a diversificar sua economia, o que atingiu diretamente a composição da sociedade. ${ }^{463}$

O progresso econômico pátrio acabou sendo atingido em 1929 com o crash em Wall Street, que afetou todo o mundo capitalista. As exportações de café caíram cerca de 50\%

${ }^{462}$ História do Brasil: uma interpretação. São Paulo: Senac São Paulo, 2008. p. 639, 640, 798 e 870.

${ }^{463}$ Skidmore, Thomas E. Uma história do Brasil. São Paulo: Paz e Terra, 1998. p. 139 a 141. 
em menos de quatro meses e o Brasil perdeu em pouco tempo sua reserva cambial estrangeira, com as trocas pelos comerciantes da moeda brasileira por dólares, libras esterlinas e ouro. ${ }^{464}$

Vargas assumiu o poder nesse momento de crise econômica e de rearranjo das oligarquias. Seu governo era caracterizado pelo centralismo e pelo sistema de manipulações, com destaque para a eliminação de opositores. Não houve grandes mudanças na estrutura de produção, nem uma reorganização das propriedades rurais e urbanas ou do capital. As alterações ocorreram principalmente na implantação de uma indústria de base e na formação de relações trabalhistas, ${ }^{465}$ garantindo direitos e aproximando a classe proletária do Estado.

Diante da crise, ao invés de cortar gastos e equilibrar o orçamento, o Governo aumentou a despesa, principalmente com a compra do café excedente o que, além de acalmar os fazendeiros, elevou o preço do produto no exterior. Com essa medida, houve aumento no capital que circulava no país, o que permitiu que o Brasil se recuperasse da crise e mais uma vez estimulasse a industrialização. ${ }^{466}$

O Governo Vargas também propôs uma atualização das legislações nacionais. O objetivo era atender às necessidades de um país que rompia os laços com a República Velha. Entre as reformas destacava-se a do Código Civil, sendo nomeada inclusive uma sub-comissão em 1931 para tratar do assunto, medida abandonada pouco tempo depois. ${ }^{467}$

A grande inovação do período consistiu na criação da Justiça Eleitoral em 1932. O novo órgão passou a ser responsável pela fiscalização das eleições (até então tarefa das autoridades municipais e estaduais) e pela proteção do voto secreto, medidas que visavam diminuir a influência dos coronéis nas diversas partes do país. Não controlando mais as eleições, a elite agrário-exportadora perderia gradativamente o seu poder sobre a classe média e a possibilidade de definir a ocupação de cargos públicos. Por mais que as providências para

\footnotetext{
${ }^{464}$ Ibidem., p. 142.

${ }^{465}$ Lopez, Adriana e Mota, Carlos Guilherme. História do Brasil: uma interpretação. São Paulo: Senac São Paulo, 2008. p. 640 e 641.

${ }^{466}$ Skidmore, Thomas E. Uma história do Brasil. São Paulo: Paz e Terra, 1998. p. 142 e 143.

${ }^{467}$ Segundo Eduardo Espinola e Eduardo Espinola Filho "Vitoriosa a revolução de 1930, que entrava de iniciar um trabalho de modernização de nossos habitos politicos e sociais, a que o Estado Novo veiu dar objetivação, achou o Governo conveniente fazer a reforma de toda legislação, sendo formada a $1^{\mathrm{a}}$ sub-comissão legislativa, para elaborar a do Código Civil". Tratado de Direito Civil Brasileiro. Rio de Janeiro: Freitas Bastos, 1939. p. 554/vol.II.
} 
a lisura das eleições não tenham surtido efeitos imediatos, inclusive pelo fato da democracia representativa ter sido suspensa por longos períodos, com o tempo, e principalmente nos grandes centros, foi-se observando maior independência do eleitorado e a perda do poder das elites locais. Apesar da iniciativa, nunca se chegou a uma total liberdade eleitoral, já que até hoje este processo continua em andamento.

O período também acolheu novas Constituições. A primeira delas surgiu em 16 de julho de 1934 tendo pequena duração, já que em 1935 foi decretado Estado de Sítio. A segunda veio em 10 de novembro de 1937, coroando o golpe militar que deu origem ao Estado Novo, período em que o sistema representativo foi extinto, as liberdades públicas foram suspensas e o Estado aumentou a tutela sobre a sociedade. ${ }^{468}$

Com a Segunda Guerra Mundial, o país novamente sofreu com a diminuição das exportações e importações. No entanto, como o processo de industrialização estava em curso, pode-se estimulá-lo com a substituição das importações por produtos fabricados no país.

O fim do conflito mundial gerou também mudanças na esfera política, já que a ditadura getuliana não conseguiu mais manter-se. Tornava-se um contra-senso sua permanência em um país que havia lutado pela liberdade e contra os Estados totalitários. Assim, em 1945, foi restaurada a ordem constitucional com a previsão de eleições gerais e o afastamento aparente (o presidente eleito foi Eurico Gaspar Dutra, o ex-Ministro da Guerra do antigo governo) de Getúlio Vargas do poder. Já no ano seguinte, em 18 de setembro de 1946 foi publicada a quinta Constituição do país.

Todo esse período, iniciado alguns anos antes da Revolução de 1930, foi marcado pela substituição gradativa de uma sociedade oligárquica agrário-exportadora por uma urbanoindustrial $^{469}$, como decorrência da industrialização e do êxodo rural.

Mas essa gradativa modificação não atingiu todo o país. Como defendiam os adeptos do "dualismo", existiam "dois Brasis": a região sul, industrializada e urbana, e a

\footnotetext{
${ }^{468}$ Lopez, Adriana e MотA, Carlos Guilherme. História do Brasil: uma interpretação. São Paulo: Senac São Paulo, 2008. p. 684 e 685.

${ }^{469}$ Lopez, Adriana e Mota, Carlos Guilherme. História do Brasil: uma interpretação. São Paulo: Senac São Paulo, 2008. p.700.
} 
região norte, ainda dominada por latifúndios improdutivos e essencialmente rural, o que mantinha forte o domínio das oligarquias-agrícolas. ${ }^{470}$

A manutenção dessa desigualdade econômica entre as duas regiões também proporcionava uma diferença de mentalidades, hábitos e relações sociais, o que trouxe anos depois a discussão sobre a conveniência de atualizar-se o Código Civil, de maneira uniforme, em todo o país. Para Orlando Gomes, as regiões mais atrasadas não poderiam atrapalhar o progresso de alguns setores mais adiantados da sociedade. Porém, o autor não defendia uma revolução nas instituições jurídicas. Para ele, era fundamental um equilíbrio; de um lado, não se podia confundir a vontade de se manter as tradições com os "sentimentos e convicções", que na verdade resultavam de um atraso econômico e cultural por parte da população brasileira. Por outro, o espírito de conservação da lei deveria ser preservado, já que o código não poderia ser utilizado para a elaboração de um plano político e social. ${ }^{471}$

Por mais que as oligarquias rurais mantivessem o seu poderio em algumas regiões do país, os inúmeros fatos ocorridos ao redor do mundo a partir da Revolução Russa em 1917 até o final da segunda guerra, levaram a uma progressiva mudança na sua relação com a terra. Aumentaram-se as críticas ao sistema capitalista e ao excesso de individualismo nas legislações, que buscavam atender os interesses das pessoas físicas sem se preocupar com a coletividade.

Como o Código Civil de 1916 havia sido construído sobre esta mentalidade, e pelo novo entendimento almejava-se a conciliação entre os interesses da coletividade e a dignidade humana, tornou-se ainda mais urgente sua atualização. Para Orlando Gomes, o novo direito privado deveria proteger a personalidade humana nas relações pessoais e a coletividade nas relações patrimoniais. ${ }^{472}$

Para atender ao interesse coletivo, o direito de propriedade perdeu seu caráter absoluto, sofrendo limitações pelo direito público (regulamentos administrativos) e pelo direito privado (com a previsão pelos anteprojetos do direito de vizinhança, por exemplo). ${ }^{473}$

\footnotetext{
${ }^{470}$ Ibidem., p.719.

${ }^{471}$ Memória Justificativa de Reforma do Código Civil. Rio de Janeiro: Departamento de Imprensa Nacional, 1963. p. 23 e 24.

${ }^{472}$ A Reforma do Código Civil. Salvador: Publicações da Universidade da Bahia, 1965. p. 23.

${ }^{473}$ Ibidem., p. 196 e 197.
} 
Essa nova maneira de regular a propriedade móvel e imóvel atingiu diretamente a elite agrário-exportadora, que até então não sofria qualquer interferência estatal em sua relação com a terra. Do mesmo modo, atingiu a elite industrial, já que os projetistas demonstravam a importância do direito de propriedade apresentar uma função social, quando exercido sob a forma de empresa. ${ }^{474}$

A concretização dessa nova concepção da propriedade ocorreu com o anteprojeto de Código Civil elaborado por Orlando Gomes, em 1963. Antes de analisar esta nova concepção (que será objeto do próximo item), importante indicar como andou a política brasileira, já que os planos de governo podem sinalizar os motivos de mudanças legislativas.

Em 1950, Vargas retornou à presidência pelo voto popular, suicidando-se quatro anos mais tarde, diante das denúncias de corrupção pelas quais passava seu governo. Café Filho, vicepresidente assumiu até a posse do novo presidente eleito, Juscelino Kubitschek (1956-1961). ${ }^{475}$

Este novo governo criou o Plano de Metas, objetivando acelerar o processo de industrialização no país. Para isso, adotou uma política centralizadora, com grande investimento público e incentivo à participação da iniciativa privada. Com suas medidas, Juscelino conseguiu que o país desenvolvesse rapidamente sua economia e indústria. Mas por outro lado, o plano de crescimento sem financiamento adequado, levou ao aumento incontrolável da inflação e intensificou as desigualdades sociais ao concentrar as indústrias no centro-sul do país. ${ }^{476}$

O surto de industrialização, inclusive com a instalação de empresas estrangeiras, mais uma vez demonstrou a necessidade da existência de um sistema registrário que informasse corretamente o titular do direito de propriedade. Afinal, quando uma sociedade empresária estrangeira opta por investir em um país, interessa-lhe saber sobre a titularidade do bem imóvel que será adquirido, para que não tenha despesas futuras com longos e onerosos litígios. Se o país apresenta um bom sistema registrário, a pessoa jurídica tem maior segurança, quanto aos gastos que serão realizados com sua instalação. Caso contrário, a

\footnotetext{
${ }^{474}$ Nesse sentido Orlando Gomes nos "Lineamentos gerais da reforma". Ibidem., p. 30.

${ }^{475}$ Lopez, Adriana e Mota, Carlos Guilherme. História do Brasil: uma interpretação. São Paulo: Senac São Paulo, 2008. p.723..

${ }^{476}$ Skidmore, Thomas E. Uma história do Brasil. São Paulo: Paz e Terra, 1998. p. 204-207.
} 
sociedade empresária deverá computar entre a quantia necessária para o investimento, não só os gastos com toda e qualquer informação sobre o bem imóvel adquirido, quanto com futuras demandas judiciais.

Ademais, há total interesse em um sistema registrário adequado, que possibilite o uso da propriedade imóvel como garantia de empréstimos. Quanto maior a certeza na utilização do bem para o pagamento do crédito, maior a possibilidade de que as instituições financeiras concedam maiores quantias a menores juros. Em outras palavras, os mesmos motivos que levaram os legisladores brasileiros a regular a aquisição da propriedade imóvel pelo registro do título, em meados do século XIX, estavam presentes cem anos depois, e o sistema imobiliário, apesar de mais completo, ainda apresentava falhas.

Em 1961, com o fim do mandato de Juscelino Kubitschek, Jânio Quadros assumiu a Presidência da República tendo como principal desafio elaborar um plano de estabilização que pudesse conter a inflação. Diante das dificuldades enfrentadas no Congresso Nacional para aprovar seu programa de contenção da crise econômica, Jânio simplesmente renunciou ao cargo. $^{477}$

Assim, em menos de um ano após as eleições de 1960, o país, sem Presidente da República, era obrigado a recorrer ao vice, João Goulart. Com a substituição, a situação tornou-se mais grave, já que Goulart era visto pela direita (UDN - União Democrática Nacional) e pelos militares brasileiros como uma ameaça ao sistema político-econômico do país, pois de orientação política de esquerda, ele parecia inclinado aos direcionamentos dos países do bloco socialista. ${ }^{478}$

Depois de muito debate, os grupos políticos chegaram a um acordo e João Goulart assumiu a presidência, em um sistema parlamentarista, o que reduziu sensivelmente seus poderes. Apenas em 1963, após um plebiscito, o sistema presidencialista voltou a ser adotado. No entanto, a estabilidade democrática não durou muito tempo. ${ }^{479} \mathrm{O}$ Brasil continuava a enfrentar a crise financeira herdada do governo de Juscelino, alta inflação e diminuição nos investimentos estrangeiros. Como tentativa para conter a crise, João Goulart defendia a

\footnotetext{
${ }^{477}$ Skidmore, Thomas E. Uma história do Brasil. São Paulo: Paz e Terra, 1998. p. 209 e 210.

${ }^{478}$ Ibidem., p. 210.

${ }^{479}$ Ibidem., p. 211 e 214.
} 
desapropriação de terras e a nacionalização das refinarias de petróleo, ${ }^{480}$ o que gerou maior descontentamento por parte da elite. A situação de instabilidade econômica e as medidas socializantes contribuíram para o golpe militar, em 1964.

O governo militar prolongou-se até 1985, com a promulgação de uma Constituição em 1967, emendada em 1969 e com a publicação de diversos atos institucionais. Durante um longo período, até a crise do petróleo em 1979, a política de estabilização da economia adotada pelo novo governo surtiu efeitos benéficos, com a redução da inflação e o incentivo ao crescimento econômico. ${ }^{481}$ Esse intervalo corresponde à época de modificações na legislação registraria com o surgimento do projeto de AFrÂNIO dE CARVAlHo em 1969, propondo a implantação de um cadastro imobiliário e a publicação da Lei de Registros Públicos de 1973, instituindo a matrícula.

Mais uma vez, a história demonstrou que períodos de crescimento econômico exigem uma legislação que regule as seguranças que a transmissão da propriedade pelo registro do título devem garantir. Dessa feita, renasce o debate sobre a necessidade de conciliar as seguranças do crédito, do direito de propriedade e do comércio.

O país passou por uma nova crise econômica a partir de 1979, que o conduziu para uma transição política e para o restabelecimento do governo civil, em 1985, com a eleição de Tancredo Neves.

O período de redemocratização foi coroado com a promulgação da Constituição Federal em 1988, que trouxe uma nova maneira de disciplinar o direito de propriedade. A partir de então, segundo seu artigo $5^{\circ}$, inciso XXIII, a propriedade deveria atender sua função social, afastando definitivamente o caráter absoluto e individualista que esse direito por tanto tempo apresentou.

A Carta Magna tratou sobre matérias as quais sempre foram disciplinadas pelo direito privado. Tal intervenção modificou as bases sobre as quais o Anteprojeto de Código Civil era elaborado e, conseqüentemente, levou à suspensão de seu trâmite nas Casas

${ }^{480}$ Ibidem., p. 214 e 215.
${ }^{481}$ Ibidem., p. 225 e 226. 
Legislativas, por algum tempo. Promulgada a nova Constituição da República e passados alguns anos, o anteprojeto foi adaptado às novas concepções por ela adotadas.

Após quase um século da primeira tentativa de atualização do direito privado, foi publicado em 2002 o Novo Código Civil, resultado de todas as modificações por que passou a sociedade brasileira, agora menos individualista e mais preocupada com a coletividade. Essa postura, gradativamente construída ao longo dos anos, influenciou diretamente a maneira como a transmissão da propriedade imóvel pelo registro do título e as seguranças que ela veio atender foram disciplinadas. Mais uma vez, resta analisar se a legislação pátria conseguiu o tão almejado e antigo desejo de convivência das seguranças do crédito, do direito de propriedade e do comércio.

\subsection{Antecedentes da lei n. 6.015 de 1973: Lei de Registros Públicos}

Iniciada a Era Vargas, a preocupação em aprimorar o sistema de registro de imóveis, permitindo a segurança do crédito e do direito de propriedade e até mesmo obtendo a almejada segurança do comércio persistiu.

A transmissão da propriedade imóvel pelo registro do título previsto no Código Civil de 1916 continuou a sofrer pequenos ajustes ou confirmações por meio de legislações federais que regulavam o registro de imóveis.

Em 9 de novembro de 1939 foi publicado o decreto n. 4.857. Diferentemente do que se esperava, a norma não trouxe inovações (inclusive quanto à transmissão da propriedade pelo registro do titulo), o que gerou manifestações de descontentamento por parte dos doutrinadores, principalmente pelo fato dos autores do decreto terem tido total liberdade para sua elaboração, não havendo vinculação a nenhuma norma anterior.

Essa liberdade legislativa contrastava com as restrições sofridas pelos elaboradores do decreto de 1928, que foram convocados a escrever uma norma que regulasse a execução dos serviços de registro público, reorganizados pelo decreto n. 4.827 de 1924. Assim, como o decreto de 1928 tinha como função apenas esclarecer dispositivos já existentes no 
ordenamento jurídico, não havia possibilidade de muita inovação. A simples previsão do princípio da continuidade gerou debates incansáveis entre os juristas (item 3.4).

Dessa maneira, como apesar das restrições o decreto de 1928 havia aprimorado o sistema, com a previsão do princípio da continuidade, os doutrinadores esperavam que os legisladores de 1939, diante de toda liberdade que possuíam, apresentassem um sistema registral imobiliário completo, resolvendo as pendências que a sociedade exigia. No entanto, não foi o que ocorreu; o decreto de 1939 praticamente reproduziu as legislações anteriores, mormente a de 1928.

Segundo Philadelpho Azevedo, o decreto de 1939 deveria ter sido apresentado aos juristas e estudiosos antes de sua publicação, o que era feito, com freqüência, com os Códigos e as leis mais importantes. Dessa maneira, com maior cautela na elaboração do texto normativo, provavelmente ter-se-iam evitado repetições, como aconteceu com a reprodução literal do decreto n. 18.542 de $1928 .^{482}$

Para o autor, o legislador tinha perdido a oportunidade de fixar linhas precisas do instituto de registro, além de solucionar todas as questões que haviam surgido nos dez anos da última publicação de uma lei registral, ou seja, a de $1928 .{ }^{483}$

No mesmo sentido de critica ao decreto, João Rabello de Aguiar Vallim, acreditava que a obra "elaborada intra muros, sem a prévia publicação do projeto" apenas havia considerado a realidade da Capital Federal, ignorando as peculiaridades das diversas regiões do país. O decreto apenas serviria para beneficiar oficiais e tabeliães, confundindo "regulamento de serviços" com "regulamento de custas". ${ }^{484}$

O novo decreto regulou os registros públicos, destinando mais de 130 artigos ao Registro de Imóveis. Dispôs sobre atribuições (art. 178 a 181), escrituração (182 a 199) processo de registro (art. 200 a 235), pessoas (art. 233 a 236), títulos (art. 237 e 238), transcrição (art. 239 a 251), inscrição (art. 240 a 282), averbação e cancelamento (art. 283 a

\footnotetext{
${ }^{482}$ Registros Públicos. Archivo Judiciário/Jornal do Commercio, Rio de Janeiro: Rodrigues e CIA, 1940, p. 79/vol.LII.

${ }^{483}$ Ibidem., mesma página.

${ }^{484}$ Direito Imobiliário Brasileiro (doutrina e prática). São Paulo: Revista dos Tribunais, 1980. p.62.
} 
296). Em suma, o decreto de 1939 disciplinou o registro de imóveis em seus aspectos formais e materiais, da mesma forma como havia feito com o de 1928.

Dentre as previsões, destaca-se que as transcrições das transferências de imóveis continuaram a ser feitas no livro de forma seguida, de acordo com a data de apresentação do título e em folha coletiva, ou seja, em uma mesma folha constavam as transcrições de diversos imóveis. Além disso, as averbações mantiveram-se à margem do assento (art. 184 e 185). Assim, não houve qualquer progresso em direção a um cadastro da propriedade imobiliária ou à adoção de folhas individuais para o registro das mutações jurídico-reais de cada bem imóvel.

Entre as inovações, ressalta-se a exigência em se averbar a construção sobre o imóvel, tornando a descrição contida no assento registral ainda mais fiel a realidade (art. 285). Para Picanço, a lei acertou ao fazer essa exigência, mas exagerou ao impor a averbação da reconstrução ${ }^{485}$, ou seja, caso houvesse alguma reforma que levasse à demolição e, em seguida, à edificação, fazia-se necessário constar no livro todas as etapas.

A posição do autor só teria razão nos casos em que a nova edificação fosse semelhante à construção antiga, o que parece muito improvável. Quando se averba a construção de um imóvel, passam a constar no assento registral todas as medidas e características da edificação, o que constitui mais um fator de identificação do bem, aspecto fundamental em um sistema que não adotava até então qualquer espécie de cadastro. Assim, se há modificação na descrição do imóvel, é fundamental que conste no livro, para que persista a correspondência entre as informações registrárias e a realidade fática.

Tanto é verdade que, a construção facilita a identificação do imóvel, que nos casos em que não houvesse nenhuma edificação, as exigências quanto sua especificação aumentavam. Na escritura pública ou instrumento particular de aquisição de terreno, ou em atos judiciais a ele referentes era necessário indicar se o imóvel ficava do lado par ou ímpar do logradouro, ou a que distância métrica do prédio ou da esquina mais próxima, além de todas as qualificações comuns nos casos de transcrição (final do art. 248).

${ }^{485}$ Dos registros públicos. Rio de Janeiro: A.Coelho Branco $\mathrm{F}^{\circ}, 1940$. p. 100. 
Outro aspecto do decreto que PicAnço ressaltava era a não exigência do registro da cessão de herança, apesar do Código Civil (artigo 44, III) equiparar a sucessão aberta aos imóveis. Para o autor, a não imposição decorria da impossibilidade de caracterizar a escritura de cessão de direito de acordo com a exigência do art. 247 do decreto de 1939. O dispositivo previa a descrição do imóvel, individualização que na maioria dos casos não se tornava possível uma vez que a herança era uma universalidade de bens. ${ }^{486}$

O interessante na opinião do autor não era, como poderia parecer à primeira vista, a justificativa pela não exigência pelo decreto do registro da cessão, mas sim o fato de pela primeira vez um jurista preocupar-se, mesmo que de relance, com o registro da cessão de herança. ${ }^{487}$

Sabe-se que por muito tempo se discutiu sobre a necessidade de se registrar a partilha do bem ou a adjudicação do imóvel ao herdeiro único, como exigência para a formação de uma cadeia de títulos. No entanto, em nenhum desses debates, levantou-se a questão da cessão dos bens da herança, ou ainda, se a ausência de sua transcrição não prejudicaria a aplicação do perseguido princípio da continuidade. Como não se exige que haja a transcrição do imóvel em nome do herdeiro, é possível que antes do registro da aquisição causa mortis ele ceda a herança a terceiro. Este irá requisitar a transcrição em seu nome, constando o registro anterior em nome do de cujos. Fica claro que há nesse caso um lapso na cadeia registrária, já que não há referência ao fato de que o imóvel pertenceu por algum tempo ao herdeiro. Resta saber se esse "defeito" na continuidade registrária irá atingir a segurança jurídica do registro.

Quanto ao princípio da continuidade, PICANÇo apenas abordava a questão relativa à impossibilidade de se exigir a transcrição, nos casos em que a legislação anterior não a previa (debate comum na época da publicação do decreto n. 18.542 de 1928). Assim, o autor entendia infeliz a redação do art. 214 do decreto de 1939 que dispunha:

\footnotetext{
${ }^{486}$ Ibidem., p. 100 e 129.

487 Ao longo de toda a pesquisa, não foi encontrado nenhum autor que antes de Melchiades PiCANÇO tivesse abordado esse tema. Parece que o assunto passou a interessar aos juristas apenas recentemente.
} 
Art. 214. Se o imovel não estiver lançado em nome do outorgante, o oficial exigirá a transcrição do título anterior, qualquer que seja a sua natureza, para manter a continuidade do registo.

Segundo o autor, não eram em todos os casos que a continuidade deveria ser "mantida", afinal quando o ato anterior não dependesse de registro por determinação expressa de lei, a cadeia registrária começaria com a primeira transmissão. Assim, o verbo "manter" apenas estaria condizente nos casos em que houvesse registro anterior. ${ }^{488}$

O próprio decreto, alguns artigos adiante, reconhecia essa impossibilidade admitindo a transcrição sem que houvesse o prévio registro do título anterior nos casos em que a lei revogada permitia esta situação. O dispositivo previa:

Art. 244. Em qualquer caso, não se poderá fazer a transcrição ou inscrição sem prévio registro do título anterior, salvo si este não estivesse obrigado a registro, segundo o direito então vigente, de modo a assegurar a continuidade do registro de cada prédio, entendendo-se por disponibilidade a faculdade de registrar alienações ou operações dependentes, assim, da transcrição anterior.

Dessa forma, havia uma contradição entre os artigos 214 e 244 do decreto, um exigia o registro do título anterior em todos os casos, o outro fazia ressalvas.

Mas a redação do artigo 244 durou muito pouco tempo; menos de quatro meses após a publicação do decreto de 1939, ele foi alterado pelo decreto n. 5.318 de 26 de fevereiro de 1940, que modificou 28 de seus dispositivos. Apesar das alterações sofridas, o decreto de 1939 continuou sendo objeto de crítica, e uma delas se referia, justamente, à nova redação do artigo 244:

Art. 244. Em qualquer caso não se poderá fazer a transcrição ou incrição sem prévio registo do título anterior, e quando nenhum haja, do último anterior ao Código Civil, salvo se este não estivesse obrigado a registo, segundo o direito então vigente, de modo a assegurar a continuidade do registo de cada prédio, entendendo-se por disponibilidade a faculdade de registar alienações ou onerações dependentes, assim, da transcrição anterior. ${ }^{489}$

${ }_{488}$ Dos registros públicos. Rio de Janeiro: A.Coelho Branco F ${ }^{\circ}$, 1940. p. 113 e 114.

${ }^{489}$ Grifo nosso. 
Por mais surpreendente que possa parecer, o legislador além de não excluir a contradição existente entre os artigos 214 e 244, trouxe maior imprecisão ao dispositivo.

Segundo PiCANÇO era estranho que um dispositivo do decreto se referisse à inexistência de qualquer título e, logo em seguida, exigisse o registro do último título anterior a vigência do Código Civil. Isso significava dizer que a lei reconhecia a existência de um título. No entanto, como o decreto de 1939 dispunha sobre a execução dos serviços concernentes aos registros públicos estabelecidos pelo Código Civil, o coerente seria seu artigo referir-se unicamente ao período posterior ao Código. ${ }^{490}$

O decreto de 1939 também foi acusado de prever vários dispositivos, que contrariavam artigos do Código de Processo Civil que, apesar de ainda não estar vigente, havia sido publicado em 18 de setembro de 1939. Essa crítica manteve-se com o decreto de 1940, uma vez que esse não se preocupe em eliminar as discordâncias. ${ }^{491}$

Dessa forma, mais uma vez o legislador brasileiro adiou o aprimoramento do sistema registrário, não atendendo às reivindicações doutrinárias que propiciariam uma maior segurança jurídica, principalmente quanto ao comércio, melhorando a regulamentação referente à transmissão da propriedade imóvel pelo registro do título.

Diante de tantas legislações e de tão pouco ou nenhum aperfeiçoamento, AfrânIO de Carvalho, professor da Universidade Federal do Rio de Janeiro, resolveu preparar um Projeto de Reforma Agrária e, anos depois, um Anteprojeto de Reorganização do Registro de Imóveis. O primeiro, concluído em 1947, foi enviado ao Ministério da Justiça e sem qualquer correção remetido ao Congresso, não chegando a se converter em lei. A sua grande inovação consistia na adoção de um cadastro para cada propriedade rural. ${ }^{492}$

\footnotetext{
${ }^{490}$ Dos registros públicos. Rio de Janeiro: A.Coelho Branco F ${ }^{\circ}$ 1940. p. 127.

${ }^{491}$ VALLim enumera algumas das divergências "mandava esse Regulamento transcrever a partilha decorrente de desquite, quando o Código ordenava averbar; determinava o registro por extrato do bem de família, quando o Código mandava faze-lo integral; não admitia o cancelamento do registro em virtude de sentença sujeita a recurso extraordinário quando o Código dizia que este recurso não suspende a execução da sentença, etc.". Direito Imobiliário Brasileiro (doutrina e prática). São Paulo: Revista dos Tribunais, 1980. p. 62 e 63.

${ }^{492}$ CARvalho, Afrânio de. Prefácio in Registro de Imóveis. $3^{\mathrm{a}}$ ed., Rio de Janeiro: Forense, 1982. p. VII e VIII.
} 
O segundo foi entregue ao mesmo Ministério, em fevereiro de 1969, que enviou a obra às Corregedorias de Justiça dos Estados. ${ }^{493}$ Algumas delas se mostraram animadas com a iniciativa, já que chegaram a analisar o trabalho. No entanto, todo empreendimento frustrou-se com o surgimento de um decreto-lei, que visando regular os registros públicos, nunca entrou em vigor. ${ }^{494}$ Trata-se do decreto-lei n. 1.000, de 21 de outubro de 1969, que diante de suas falhas e imperfeições teve sua vigência sucessivamente prorrogada por seis vezes, ${ }^{495}$ sendo por fim, substituído pela lei n. 6.015 de 1973.

Abandonou-se assim, sem muita explicação o anteprojeto de Afrânio de Carvalho, mesmo este constituindo um avanço ao sistema imobiliário brasileiro, diferentemente do que representava o decreto-lei de 1969. O professor buscava conciliar em seu trabalho a segurança da propriedade e do comércio, o que, conseqüentemente, melhorava o modo de aquisição de propriedade imóvel pelo registro do título. Para isso previu o cadastro, que realizado com base na cobertura aerofotográfica do País, teria como objetivo determinar o espaço geográfico que ocupava cada imóvel submetido à inscrição (art. 22). As informações existentes no cadastro poderiam ser utilizadas para o levantamento da planta do imóvel, que realizada por topógrafo habilitado, instruiria o título que fosse apresentado para inscrição. Da mesma maneira, essas plantas renovariam o cadastro, projetando nele todas as transformações ocorridas.

Com a previsão de um cadastro mapeando a situação imobiliária do país, sistema registrário brasileiro aproximava-se do alemão e, como conseqüência, poder-se-ia pensar em admitir o princípio da fé pública. E foi nesse sentido que o Anteprojeto caminhava. Previa expressamente em seu artigo 12, a presunção absoluta do registro para aquele que, desconhecendo a sua inexatidão, adquirisse o imóvel a título oneroso. Assim, o ordenamento não protegeria o adquirente de boa-fé a título gratuito nem aquele que estivesse de má-fé.

Além da previsão do cadastro e do princípio da fé pública, que permitiriam obter em longo prazo a conciliação entre a segurança do direito de propriedade e do comércio, o anteprojeto inovava com o uso apenas do termo "inscrição", acabando com a divisão histórica entre ele e "transcrição" (art. 27). Ainda previa que cada folha do livro fundiário fosse

\footnotetext{
${ }^{493} \mathrm{O}$ anteprojeto foi obtido no apêndice do livro do autor. Ibidem., p. 562 a 568.

${ }^{494}$ Ibidem., p. VII e VIII.

${ }^{495}$ O decreto-lei n. 1.000 de 1969 e os seis decretos que prorrogaram sua execução foram obtidos na obra FrançA, Limongi R. Legislação dos Registros Públicos. São Paulo: Revista dos Tribunais, 1976. p. 241-305.
} 
destinada a um único imóvel. Em seu cabeçalho deveria constar o título aquisitivo com a descrição do bem, seguido por todos os atos posteriores que lhe dissessem respeito. (art. 18, caput). A essa inscrição aquisitiva dava-se o nome de matrícula do imóvel que era independente e distinta do cadastro (art. $18, \S 1^{\circ}$ e $\S 4^{\circ}$ ).

Assim que um título fosse apresentado na vigência da lei, o sistema de folha única e de matrícula deveriam ser aplicados. Caso esse primeiro título não fosse aquisitivo, seria transladado o último ato de aquisição (art. 18, $\$ 1^{\circ}$ ). Esse dispositivo demonstrava a preocupação do autor em aplicar imediatamente o novo regime, evitando confusões, como aconteceria se a matrícula fosse exigida apenas com a primeira inscrição de um título aquisitivo, o que levando todos os outros a serem inscritos ou transcritos nos moldes do decreto de 1939. Uma execução imediata diminuiria o prazo de convivência dos dois sistemas, o que era indispensável para a adoção do princípio da fé pública.

Por fim, o anteprojeto previa a extinção do Registro Torrens (art. 33) o que se mostrava coerente com a adoção do cadastro e do princípio da fé pública no sistema imobiliário comum. Afinal, a presença dessas características no modelo ordinário esvaziava o sentido do Registro Torrens, salvo no que dizia respeito à mobilidade da propriedade imóvel.

Apontados os principais aspectos do Anteprojeto, vale fazer algumas considerações.

É questionável a possibilidade de aplicação desse sistema inovador diante da caótica realidade imobiliária do país Tanto a adoção do princípio da fé pública, nos casos do adquirente de boa-fé a título oneroso, quanto a instituição de um cadastro, parecem um pouco precipitadas. A realização de um cadastro nacional com base na cobertura aerofográfica da forma como previa o anteprojeto provavelmente demoraria alguns anos, senão vários, para se concretizar. E enquanto não houvesse o mapeamento de todo o país, proteger o direito do adquirente de boa-fé a título oneroso seria privilegiar a segurança do comércio, em detrimento do direito de domínio do real proprietário, uma vez que eram grandes as chances de não haver correspondência entre a situação fática e as características contidas no assento. 
A idéia de criação de um cadastro nacional dos imóveis é louvável, sendo mesmo o que se esperava de uma legislação que viesse aprimorar o sistema de registro. O problema estava na aplicação imediata do princípio da fé pública. O ideal seria que o Anteprojeto previsse o cadastro e a matrícula como fez, mas mantivesse a força probante relativa do registro para todas as situações. Apenas muitos anos mais tarde, quando o cadastro e a matricula do bem fosse a realidade imobiliária do país, poder-se-ia pensar em adotar o princípio, obtendo-se dessa forma, quem sabe, a convivência pacífica entre as tão almejadas seguranças do comércio e do direito de propriedade.

Apesar da possível necessidade de correções pontuais, o Anteprojeto de AfRÂNIO DE Carvalho apresentava inovações significativas. Assim, é estranho que as discussões ao seu redor tenham sido afastadas para o surgimento do decreto-lei n. 1.000 de 1969 que não trazia nenhum benefício ao sistema imobiliário brasileiro. Maior progresso haveria no campo registral, se os legisladores tivessem se centrado no projeto do professor fluminense e aperfeiçoado-o, de acordo com as possibilidades nacionais.

O intuito do decreto-lei n. 1.000 de 1969 era modificar e atualizar o infeliz decreto n. 4.857 de 1939, tendo-o como base. Pela exposição de motivos, seus autores justificavam a elaboração da nova norma em basicamente dois fatores. O primeiro seria a necessidade de concentrar em um único monumento legislativo todas as alterações que os registros públicos haviam sofrido após a publicação do decreto de 1939. O segundo, a necessidade de simplificar a escrituração e arquivamento dos livros e documentos dos cartórios de notas e registro, conciliando o sistema com as novas tecnologias. ${ }^{496}$

Entre as modificações trazidas pelo decreto-lei (que, destaca-se, nunca chegou a vigorar) pode-se apontar a possibilidade dos livros possuírem folhas soltas, o que facilitaria a utilização de meios mecânicos de escrituração, não mais exigindo que todos os registros e averbações fossem feitos à mão (art. $5^{\circ}$, parágrafo único). Ademais, diminuía a diversidade dos livros registrais, concentrando os atos realizados nos livros 2, 3 e 4 do decreto de 1939, no livro de registro geral. (art. 170, b). A iniciativa tinha como objetivo preparar o sistema para

${ }^{496}$ Trecho da Exposição de Motivos transcrito in Batalha, Wilson de Souza Campos. Comentários à Lei de Registros Públicos. $4^{\mathrm{a}}$ ed., Rio de Janeiro: Forense, 1997. p. 15 e 16/vol.I. 
um regime de "registro próprio" para cada imóvel, facilitando uma futura adoção do cadastro. $^{497}$

Por fim, o decreto-lei ampliava os requisitos para o registro da transmissão da propriedade imóvel, aprimorando o princípio da especialidade inclusive em seu aspecto subjetivo, que por tanto tempo tinha sido negligenciado pelos legisladores pátrios. Dessa forma, incluiu entre as condições necessárias para a realização do registro, a referência ao estado civil e nacionalidade do adquirente e do transmitente.

A exigência de se constar no registro a nacionalidade do adquirente do imóvel foi conseqüência de políticas nacionais, que buscavam restringir a aquisição de terras rurais por estrangeiros, fazendo com que a transação ficasse condicionada à autorização do Ministério da Agricultura, obtida por meio do Instituto Brasileiro de Reforma Agrária (IBRA) conforme previsto no art. $1^{\circ}, \S 3^{\circ}$ do decreto-lei n. 494 de 10 de março de 1969.

Já no relativo à exigência do estado civil, sua previsão facilitava o trabalho do registrador, uma vez que ficava clara a necessidade ou não de se exigir a outorga uxória na realização de ato pleiteado pelo interessado (art. 235 e 242 do Código Civil de 1916). Mais completo seria se, além do estado civil, a lei previsse, em caso de matrimônio, a referência expressa ao regime de bens adotado pelo casal.

Se por um lado o decreto-lei trazia inovações positivas, por outro, conservava a prática de realizar em uma única folha o registro de tantos imóveis quantos nela coubessem, afastando o princípio da ficha única, que facilitaria as buscas e aproximaria o sistema de uma futura adoção da matrícula. Ademais, manteve a redação de seu artigo 229, semelhante ao artigo 244 do decreto de 1940, que se referindo ao registro do titulo anterior para a formação da cadeia registraria, foi alvo de críticas pelos doutrinadores, como aquela realizada por Melchiades Picanço.

${ }^{497}$ Brasil. Anais da Câmara dos Deputados, vol.12. Sessões de 24 de agosto a 4 de setembro de 1972. Brasília: Oficinas do Serviço Gráfico da fundação IBGE, [s.d.], p. 468. 
A entrada em vigor do decreto-lei foi prorrogada por seis vezes. Na primeira delas, o motivo alegado pelas autoridades foi o exíguo prazo conferido pela norma aos Cartórios para cumprirem as disposições, inclusive para a prepararem os livros de registro. ${ }^{498}$

Na segunda prorrogação, a razão alegada foi outra. Como o Poder Executivo havia enviado um projeto de lei ao Congresso Nacional, alterando vários artigos do decreto-lei, pareceu mais conveniente aguardar a estrutura definitiva da norma, antes de colocá-la em vigência. Quanto aos demais decretos, não havia justificativa do porquê da prorrogação, mas tudo indicava que o último motivo alegado ainda fazia-se presente.

O desejo em corrigir os dispositivos do decreto-lei era tamanho que, em 1972, o senador AcCiOly Filho enviou à Câmara dos Deputados um outro projeto de lei. No parecer da Comissão de Constituição de Justiça pela constitucionalidade, juridicidade e aprovação do projeto ficava clara a preocupação de seu autor (e relator) e da Corregedoria de Justiça do Estado de São Paulo (que apresentou várias sugestões ao esboço legislativo) em retificar os artigos do decreto-lei que contrariavam a própria justificativa que antecedeu sua publicação. Assim, segundo o senador, para que a simplificação dos livros surtisse o efeito esperado, ou seja, preparasse o regime para um futuro cadastro, era fundamental a adoção de prévia matrícula dos imóveis, na qual se realizaria o registro e averbação dos atos e instrumentos que tivessem como objeto aquele bem. Esse novo sistema motivaria a substituição dos livros convencionais por folhas soltas, nas quais seria possível utilizar os meios mecânicos de escrituração e facilitaria a reprodução por processos fotocopiativos. ${ }^{499}$

Outra correção do projeto (pertinente ao objeto desse estudo) referia-se ao uso dos termos "inscrição" e "transcrição", os quais apesar do autor do decreto-lei afirmar que eles seriam englobados na palavra "registro", não o foram. A obra do senador também inovava ao

\footnotetext{
${ }^{498}$ Segundo Regnoberto M. de Melo, a pequena vacatio legis de apenas 60 dias "gerou incompatibilidades insanáveis à boa ordem do serviço público registral. Os registradores não dispunham de tempo para preparar os livros de serviço, aptos a atenderem as novas demandas legais. Agravava a situação o fato de que se tratava de lei a ser cumprida em todo o território nacional. Muitas rotinas assomadas no Decreto-Lei $\mathrm{n}^{\circ} 1.000$ eram novidadeiras, gerando inseguranças e incertezas na execução dos serviços registrais até então baseados no Decreto Legislativo $\mathrm{n}^{\circ} 4.827$ de 1924 . O governo viu-se, então, obrigado a prorrogar o prazo para a execução das exigências e preparar urgente projeto de lei que curassem defeitos já então revelados”. Lei de Registros Públicos Comentada. Rio de Janeiro: Freitas Bastos, 2003. p. 22 e 23.

${ }^{499}$ Brasil. Anais da Câmara dos Deputados, vol.12. Sessões de 24 de agosto a 4 de setembro de 1972. Brasília: Oficinas do Serviço Gráfico da fundação IBGE, [s.d.], p. 468 e 475.
} 
excluir o livro de Indicador Real, omissão que era justificada pela existência do livro de registro geral, que contendo a matricula, os registros e averbações de cada bem, faria às vezes daquele (bastando unicamente confeccionar um índice, para que a identificação fosse perfeita). ${ }^{500}$

Accioly Filho criticava o artigo 229 do decreto-lei, que repetindo a redação de 1940, cogitava a possibilidade de não existir a transcrição do título que antecedia aquele que se procurava lançar no livro. Para o autor, em 1972, essa situação era inadmissível, uma vez que a falta do registro poderia ser suprimida pela declaração judicial de usucapião. Logo, era fundamental que a legislação exigisse a matrícula e o registro de todos os títulos anteriores sem qualquer ressalva. ${ }^{501}$

Por fim, o projeto eliminava as repetições inúteis encontradas ao longo da norma de 1969, como, por exemplo, a reprodução do texto relativo às atribuições gerais do registro de imóveis, no capitulo referente aos atos que eram realizados em cada um dos livros. Com as modificações, o senador Accioly FiLHo entendia que o problema da redação deficiente do decreto-lei, que até então impedia sua vigência, seria solucionado. ${ }^{502}$

A tentativa de correção do decreto-lei de 1969 mostrava a inclinação dos legisladores brasileiros pela adoção de um sistema registrário que pudesse preparar o regime para um futuro cadastro. Tratava-se de um plano intermediário entre o direito vigente e a sugestão apresentada por AfRÂNIO DE CARVALHO em seu Anteprojeto, pois apesar de prever a matrícula de todos os imóveis e o sistema de folha única, não admitia o cadastro ou mesmo o princípio da fé pública.

Mesmo com as inúmeras tentativas de correção do decreto-lei de 1969, ele acabou sendo revogado. Pareceu melhor aos legisladores elaborar uma nova norma, ao invés de insistir naquele que, por apresentar falhas e imperfeições, tinha sido alvo de tantas críticas.

\footnotetext{
${ }^{500}$ Brasil. Anais da Câmara dos Deputados, vol.12. Sessões de 24 de agosto a 4 de setembro de 1972. Brasília: Oficinas do Serviço Gráfico da fundação IBGE, [s.d.] p. 472 e 474.

${ }^{501}$ Brasil. Anais da Câmara dos Deputados, vol.12. Sessões de 24 de agosto a 4 de setembro de 1972. Brasília: Oficinas do Serviço Gráfico da fundação IBGE, [s.d.] p. 476 e 477.

502 Brasil. Anais da Câmara dos Deputados, vol.12. Sessões de 24 de agosto a 4 de setembro de 1972. Brasília: Oficinas do Serviço Gráfico da fundação IBGE, [s.d.], p. 469 e 473.
} 
Assim, em 31 de dezembro de 1973 surgiu a Lei de Registros Públicos para substituir o decreto-lei de 1969. Antes mesmo de entrar em vigor, a norma sofreu severas críticas de AfrâNIO DE CARVALHo, para quem a lei não satisfazia a cultura jurídica nacional. ${ }^{503}$

A nova lei trazia algumas modificações, mas conservava dispositivos sobre os quais vinham-se pleiteando mudanças. Quanto às alterações, destacava-se a previsão da possibilidade dos livros serem escriturados mecanicamente, em folhas soltas, facilitando o serviço registrario (art. $3^{\circ}, \S 2^{\circ}$ ). Pregava-se ainda, a permanência do livro n. 5 Indicador Real, que facilitava as buscas de informações sobre o imóvel e seu proprietário, apesar de iniciativas anteriores para sua abolição, como aquela defendida pelo senador AcCIOLy FilHo em 1972. Mas a grande inovação ficou com a instituição da matrícula, que nada mais era do que a primeira inscrição da propriedade no assento $^{504}$ (capítulo VI - artigos. 244 a 233).

Segundo Wilson de Souza Campos Batalha, a matrícula consiste em um assentamento básico da propriedade imóvel, que sem compor um cadastro imobiliário propriamente dito, constitui a "história de cada imóvel, com as transformações, limitações e onerações por que passou", ${ }^{505}$

Quando as aquisições de imóveis eram feitas no livro de transcrição, toda vez que um registro fosse realizado era necessário definir com precisão o bem, já que naquela folha constavam diferentes imóveis. Com a instituição da matrícula, o cabeçalho da folha recebe todas as informações do imóvel, suas características físicas e as qualificações de seu proprietário. Em seguida, são lançadas as transcrições, inscrições e averbações sobre aquele bem, podendo ser suprimidas algumas informações já existentes no alto do livro. Assim, os dados sobre a propriedade ficam concentrados em uma única folha, facilitando as buscas e aumentando a segurança nas transações.

Além de concentrar todos os dados sobre o imóvel, facilitando a sua particularização e a obtenção de informações a seu respeito, o que amplia a estabilidade

\footnotetext{
${ }^{503}$ Registro de Imóveis: última versão (Lei n. 6.015, de 1973). Revista dos Tribunais, São Paulo, v. 459, ano 63, p. $24,1974$.

${ }^{504}$ Ibidem.,p. 25.

${ }^{505}$ Comentários à Lei de Registros Públicos. $4^{\mathrm{a}}$ ed., Rio de Janeiro: Forense, 1997. p. 385 e 719/vol. I.
} 
jurídica, a matrícula simboliza uma aproximação ao sistema cadastral, indispensável para conciliar a segurança do direito de propriedade e do comércio.

Não apenas a instituição da matrícula marcou a nova lei. Pela primeira vez, uma norma referente ao registro de imóveis previu expressamente a possibilidade de retificar-se ou anular registro decorrente de ato jurídico nulo, anulável ou resultante de fraude à execução (art. 217). A previsão é importante na medida em que contraria qualquer tentativa doutrinária de acolher o princípio da fé pública no sistema registral brasileiro. Sem dúvida, como no ordenamento pátrio o registro sempre foi causal, era claro que a nulidade do título levava à nulidade do registro; no entanto, não havendo dispositivo expresso, era comum que se ressalvassem as hipóteses, envolvendo terceiro de boa-fé a título oneroso, admitindo a força probante absoluta do assento. Com a previsão na Lei de Registros Públicos, uma interpretação nesse sentido passou a ir além do que parecia desejar o legislador, uma vez que o artigo não previa qualquer exceção. ${ }^{506}$

Como assinala VALMIR Pontes, toda matrícula, transcrição, inscrição ou averbação que se seguissem ao ato, cujo título fosse reconhecido nulo por sentença judicial transitada em julgado, eram "automaticamente" atingidas e deveriam ser canceladas "por não poderem agüentar-se no ar ou sem base de sustentação real". Quanto ao direito adquirido, ele só poderia ser alegado nesse caso para obtenção de indenização. ${ }^{507}$

Mesmo com a nova disposição da lei, houve quem mantivesse a defesa do terceiro adquirente de boa-fé. Para AnTÔNIO MACEDo DE CAMPos, a nulidade do registro derivada ou não da nulidade do título não poderia prejudicar terceiros de boa-fé, que com base em certidões do registro de imóveis haviam adquirido o bem. O autor não fazia distinção nos casos de aquisição a título oneroso ou gratuito, parecendo estender a proteção também para esse grupo. $^{508}$

\footnotetext{
${ }^{506}$ Assim, por exemplo, se utilizando procuração falsa "A" vendesse a seu amigo "B" um imóvel que não lhe pertencesse e "B" sabendo da fraude o transferisse a um terceiro de boa-fé, quando a fraude fosse descoberta, o último adquirente não teria direito ao imóvel, restando-lhe apenas uma ação obrigacional. Afinal, com o reconhecimento judicial da nulidade do primeiro título, o registro também se tornava nulo e a cadeia posterior era totalmente comprometida.

${ }^{507}$ Registro de imóveis: comentários aos arts. 167 a 288 da Lei n. 6.015 de 31 de dezembro de 1973. São Paulo: Saraiva, 1982. p. 137.

${ }^{508}$ Comentários à Lei de Registros Públicos. $3^{\circ}$ vol., Bauru: Jalovi Ltda, 1977. p. 348.
} 
Destaca-se que a nulidade ou anulabilidade do registro podem ou não derivar da invalidade do título. É possível que o registro seja por si só nulo, sem que haja qualquer defeito no título que lhe deu origem. Como exemplo desse último caso, tem-se a realização do ato registral sem o cumprimento de todos os requisitos legais, o que leva à sua nulidade, mas não a do título. Nesse caso, como o erro deriva unicamente de culpa ou dolo do oficial de registro, que não cumpriu todas as exigências legais (apesar de ser sua obrigação funcional), parece injusto prejudicar terceiro de boa-fé. O ideal é que sendo possível a retificação do erro ou inclusão de dados, este seja corrigido e o adquirente de boa-fé permaneça com o domínio sobre o bem. A grande diferença para os casos de nulidade ou anulabilidade do título é que não há ninguém que seja prejudicado com a decisão de retificar o registro.

Além de dispor sobre a matrícula e a possibilidade de cancelar o registro decorrente de ato jurídico nulo, anulável ou resultante de fraude à execução, a Lei de Registros Públicos previu a utilização de folhas soltas e fichas. A medida foi severamente censurada por Afrânio Carvalho, para quem o legislador trouxe a inovação sem analisar se essa mobilidade não prejudicaria a segurança dos direitos, já que a possibilidade de "perdas, extravios e substituições fraudulentas" seria muito mais recorrente em folhas soltas e fichas do que nos antigos livros. $^{509}$

O autor apontava outros aspectos negativos da Lei. Primeiro, a determinação de que as averbações seriam feitas no corpo da folha, seguindo inscrições e transcrições, e não mais à margem do assento. Além de a mudança infringir o próprio significado da palavra "averbar" que significa escrito "por verba", à margem de outro, a nova previsão tumultuava o livro e dificultava sua análise pelo oficial. Segundo aspecto negativo, a manutenção de alguns dispositivos anacrônicos, como a separação entre os atos que seriam "transcritos" e "inscritos" (art. 168, I e II), com o agravamento de incluir na designação "registro" os dois termos e excluir o ato de averbação, apesar do significado comum daquela palavra ser "todo e qualquer assento" (art. 168, $\S 8^{\circ}$ ). Terceiro, o fato da própria lei que restringiu o conceito de "registro" ter utilizado em alguns dispositivos a sua designação comum, ou seja, que tenha incluído o ato de averbação (exemplo, os artigos 255 e 257). ${ }^{510}$

\footnotetext{
${ }^{509}$ Registro de Imóveis: última versão (Lei n. 6.015, de 1973). Revista dos Tribunais, São Paulo, v. 459, ano 63, p. 26 e $27,1974$.

${ }^{510}$ Ibidem.,p. 27.
} 
Essas não eram as únicas críticas feitas por Afrânio CARvalho à nova lei. Referindo-se ao título destinado ao registro imobiliário, o autor afirmava que ela reunia todas as informações sobre a matéria, inclusive aquelas que por serem "miúdas e mutáveis" deveriam ser reservadas a um diploma de maior "maleabilidade" como o regulamento, que dependia apenas do ato do Poder Executivo. Ademais, além de tratar do registro de imóveis, a lei dedicava-se a matérias reguladas pelos Códigos de Processo Civil e Civil. Assim, discorria sobre bem de família (Capitulo IX), remição de imóvel hipotecado (Capitulo X), registro Torrens (Capítulo XI) e criava um procedimento especial para a dúvida registraria e a retificação, ignorando aquele constante no Código de Processo Civil. O autor ressaltava que, apesar de dedicar-se a temas já disciplinados no ordenamento, a Lei de Registros Públicos não aprimorava nenhuma dessas matérias, ${ }^{511}$ o que demonstrava ainda mais a impertinência da previsão.

Quanto ao fato da Lei dispor sobre o Registro Torrens, VALmir Pontes tinha

opinião diversa, entendia que por ser a matéria menos processual do que de direito material imobiliário, mais coerente seria que fosse tratada em uma lei referente aos registros públicos e não em um no Código de Processo Civil..$^{512}$

Afrânio de Carvalho continuava suas críticas, destacando o uso exagerado do termo "registro" e tímido da palavra "matricula" que acabavam por confundir os estudiosos da Lei. Assim, elegia o capítulo relativo à matrícula como aquele que menos ordem e clareza possuía, já que o entendimento do artigo 224 de que a matrícula era o primeiro ato no assento imobiliário e que deveria ser elaborada assim que fosse apresentado qualquer título à inscrição ou averbação ${ }^{513}$ era expressamente contrariado com a previsão de que a abertura da matrícula ocorria apenas quando do primeiro registro, ou seja, da inscrição (art. 225). Essa disposição levava ao inconveniente de se averbarem as modificações que diziam respeito ao imóvel, às margens dos antigos livros de transcrição já encerrados, mantendo por prazo indeterminado o regime anterior. $\mathrm{O}$ autor afirmava que a situação ficava ainda mais séria quando o cartório era

${ }^{511}$ Ibidem., p. 24.

${ }^{512}$ Registro de imóveis: comentários aos arts. 167 a 288 da Lei n. 6.015 de 31 de dezembro de 1973. São Paulo: Saraiva, 1982. p. 228.

${ }^{513}$ A averbação é o ato que se destina a informar a existência de uma situação superveniente que não constitua domínio nem ônus real, mas que em algum aspecto altera o assento. Assim, averba-se o casamento do proprietário do bem e o regime adotado, a construção, a mudança no nome da rua e etc. 
desmembrado, uma vez que o livro de transcrição continuava na serventia antiga ofendendo a competência do oficial de registro que, por ser territorial, alterava-se assim que o desmembramento ocorria. Dessa maneira, um registrador sem atribuição na circunscrição onde estava situado o imóvel era responsável pelos atos de averbação daquele bem. ${ }^{514}$

Uma outra possibilidade de abertura de matrícula ocorria nos casos em que não mais houvesse espaço para averbações ou anotações nos Livros de Transcrição das Transmissões (art. 308, parágrafo único), medida insuficiente para a propagação da nova figura jurídica.

Todos esses problemas seriam solucionados com a previsão de que a matrícula fosse aberta quando da realização do primeiro registro, englobando este não apenas os atos de inscrição e transcrição, mas também as averbações. Essa mudança aceleraria o processo de introdução do novo sistema registrário, estimulando a abertura de matrículas, e, conseqüentemente, aprimorando a segurança dos assentos registrais com a concentração dos atos relativos aos imóveis.

Além de todas as questões indicadas por AfrÂnIO DE CARvalho destacam-se outras.

A lei reorganizou os livros registrários, determinando que a inscrição hipotecária e a transcrição das transmissões fossem realizadas no livro 2 (Registro Geral). Porém, não simplificou o processo de registro (art. 171), mantendo sem necessidade vários livros que ao distribuírem as informações sobre o mesmo imóvel, diminuíam a segurança dos direitos.

Ademais, a lei era extremamente repetitiva, como por exemplo, o caput do art. 173 com redação praticamente igual a do caput do art. 235 (acerca dos atos sujeitos ao Livro 2), o mesmo ocorrendo entre o caput do art. 197 e o parágrafo único do art. 235 (exigência do registro do título anterior para a manutenção do princípio da continuidade), semelhança entre o $\S \S 1^{\circ}$ e $2^{\circ}$ do art. 197 e o $\S 1^{\circ}$ do art. 225 (necessidade de constar na matrícula os elementos do título e do registro anterior, estando ele registrado ou não naquele Cartório).

\footnotetext{
${ }^{514}$ Registro de Imóveis: última versão (Lei n. 6.015, de 1973). Revista dos Tribunais, São Paulo, v. 459, ano 63, p. 25,1974 . Isso também acontecia nos casos em que o imóvel já com matrícula própria passasse a pertencer a outra circunscrição, pois todo título que surgisse para averbação continuaria a ser inscrito no cartório antigo, apenas em caso de registro é que era aberta uma nova matrícula na serventia competente.
} 
Algumas das críticas apresentadas à Lei de Registros Públicos contribuíram para a elaboração das leis n. 6.140 de 28 de novembro de 1974 e a n. 6.216 de 30 de junho de 1975 , que corrigiram falhas do texto original de 1973. A primeira, não interessa ao objeto deste estudo, já que se refere ao registro civil de pessoas naturais, a segunda altera, entre outros dispositivos, aqueles concernentes ao registro de imóveis, como será estudado no próximo item.

\subsection{Lei de Registros Públicos: a instituição da matrícula.}

Como visto no item acima, a lei n. 6.015 de 1973 (Lei de Registros Públicos) sofreu alterações antes mesmo de entrar em vigor. A análise do texto original pelos juristas e a indicação de possíveis incorreções foram fundamentais para o aprimoramento do diploma, destacando-se a colaboração de Afrânio CARvalho nesse sentido. Com as modificações, a

publicação da Lei de Registros Públicos constituiu um novo marco no registro imobiliário, atingindo diretamente a transmissão da propriedade imóvel pelo registro do título.

A lei n. 6.015 de 1973, após as alterações em 1974 e 1975, passou a vigorar em $1^{\circ}$ de janeiro de 1976, tendo expressamente revogado a lei n. 4.827 de 1924, o decreto n. 4.857 de 1939 e aqueles de 1940, n. 5.318 e n. 5.553.

Entre as alterações trazidas pela lei n. 6.216 de 1975 ao texto original, destaca-se a exclusão dos termos "inscrição" e "transcrição" que foram substituídos pela palavra "registro" (art. 167, I). No entanto, ela continuou não englobando o ato de "averbação", em uma falha clara do legislador. Houve ainda a diminuição no número de livros, reduzidos dos oito previstos no texto original para cinco, o que sem dúvida contribuiu para aumentar a segurança das informações (art. 173). Os requisitos da matrícula passaram a ser tratados no Título referente à escrituração, junto com os dispositivos sobre as exigências para o registro no Livro n. 2 (art. 176, II). Essa modificação foi totalmente desnecessária, uma vez que o capítulo relativo à matrícula foi mantido, tornando a lei ainda mais confusa. Ademais, a releitura crítica da Lei pelos próprios legisladores não foi suficiente para retirar alguns dispositivos repetitivos, 
como o artigo 237, que reproduz idéia semelhante àquela já apresentada pelo artigo 195 do mesmo diploma, ou seja, a necessidade do registro do título anterior, antes da realização do novo, para manter a continuidade dos atos no assento.

Como pode ser visto, das objeções apontadas por Afrânio CARvalho, poucas foram acatadas. Manteve-se o uso de fichas e folhas soltas, a abertura de matrícula apenas nos casos de título para registro, não englobando este a averbação, e esta continuou a ser realizada no corpo do assento, e não à sua margem. Ademais, aquelas matérias que para o autor não deveriam estar em uma lei sobre registros públicos, nela permaneceram, como os referentes ao bem de família (art. 260 a 265), à remição do imóvel hipotecado (art. 266 a 276) e ao Registro Torrens (art. 277 a 288).

Quanto ao uso dos sistemas de folhas soltas e fichas, ressalta-se que o receio de Afrânio de Carvalho, de que tal medida pudesse diminuir a segurança dos assentos registrais (aumentam a possibilidade de perdas, deteriorações e fraudes), não era acompanhado pelos legisladores nem pela Corregedoria de Justiça de São Paulo que, em novembro de 1975, emitiu o Provimento n. 2 recomendando aos oficiais a utilização do novo sistema, com escrituração mecânica, no lugar dos livros encadernados $\left(\operatorname{art} .5, \S 1^{\circ}\right) .{ }^{515}$

Tratava-se apenas de uma recomendação porque o oficial tinha total liberdade em escolher manter o sistema antigo de livros encadernados, ou adotar o sistema de folhas soltas ou fichas (art. $3^{\circ}$ caput e $\S 2^{\circ}$ ). A única exigência legal era a exclusão do Livro de Protocolo do sistema de fichas (art. 173, parágrafo único). Provavelmente, a justificativa para essa restrição fundamenta-se na diferença existente entre os dois modos de escrituração, já que aumenta ou diminui a possibilidade de extravios. No sistema de folhas soltas, atingindo certo número de folhas, estas são encadernadas, compondo um livro semelhante ao que era adotado. Com as fichas, estas permanecem sempre "soltas" o que parece contribuir para uma possível perda. Como no Livro de Protocolo são prenotados todos os títulos que ingressam na Serventia e nele consta a realização ou não do ato pleiteado, com remissão ao livro ou arquivo respectivo, seria importante que houvesse maior cuidado na sua manutenção.

${ }^{515}$ França, Limongi R. Legislação dos Registros Públicos. São Paulo: Revista dos Tribunais, 1976. p. 416. 
Para João Pedro Lamana Paiva, a principal inovação da Lei foi o fim da escrituração manuscrita, proporcionada pela utilização de folhas soltas e fichas, afinal, a realização de todos os atos registrais à mão, consistia em um "esforço e perda de recursos desnecessários", além de não acompanhar os "progressos da ciência". 516 Outra vantagem desse regime é tornar mais rápida a expedição de informações sobre a situação jurídica do imóvel, com a fácil reprodução das folhas e fichas por processo fotocopiativos.

Já no relativo à substituição dos termos "inscrição" e "transcrição" por "registro", não há dúvidas de que, como destacava VALMIR Pontes apesar da unificação das figuras, elas continuam tendo distinção no direito material, como sempre expressou o Código Civil. Assim, a transcrição referia-se aos títulos ou atos translativos de propriedade e a inscrição àqueles de oneração real. ${ }^{517}$

O interessante é que, no mesmo momento em que o legislador corrigiu uma imprecisão terminológica histórica (transcrição versus inscrição), ele adotou outra, ou seja, excluiu do termo "registro" o ato de averbação. O mais grave é que apesar da própria lei trazer em seu artigo 168 o que estaria englobado na palavra "registro", ela se confunde ao tratar de algumas matérias. Por exemplo, ao dispor sobre a retificação afirma "se o teor do registro não exprimir a verdade, poderá o prejudicado reclamar sua retificação...”. Nesse caso, o termo "registro" refere-se também à averbação, afinal, caso contrário, esta jamais poderia ser corrigida. Erro semelhante repete-se no artigo 252, que trata sobre a eficácia do registro, sendo que mais uma vez esse vocábulo deverá incluir o ato de averbação. O mesmo pode-se dizer dos artigos $217,218,220$ e outros.

Outra medida prevista pela lei que atinge a averbação e traz prejuízos ao sistema registral é a que determina que este ato seja realizado no corpo do assento e não em sua margem, como o significado etimológico da palavra e a tradição pudessem levar o intérprete a entender. Dessa forma, a averbação deve ser inscrita logo após o último ato, sendo precedida pelas letras AV e o número de ordem daquele lançamento (art. 232). Essa inovação é prejudicial, por dificultar a pesquisa dos assentos pelo registrador. Se o intuito dos legisladores

\footnotetext{
${ }^{516}$ A sistemática do Registro de Imóveis. $3^{\mathrm{a}}$ ed., Porto Alegre: Síntese, 1980. p. 17.

${ }^{517}$ Registro de imóveis: comentários aos arts. 167 a 288 da Lei n. 6.015 de 31 de dezembro de 1973. São Paulo: Saraiva, 1982. p. 8 e 9.
} 
era aprimorar o sistema, facilitando as buscas e fornecendo com maior rapidez e precisão todas as informações relativas ao imóvel, pecaram ao complicar o trabalho do oficial. A visualização do assento e, conseqüentemente, de todos os direitos que envolvem o imóvel, seria mais clara se a folha ou ficha única do Livro Geral mantivesse a coluna de averbação, como já havia sugerido AfrânIo de CARvalho. ${ }^{518}$

Concretizando previsão iniciada em 1928, a lei dispôs sobre o princípio da continuidade (art. 237). No entanto, provavelmente pelo adiantado dos anos, não fez qualquer

referência às hipóteses em que, devido a não exigência de transcrição de atos judiciais ou causa mortis antes do Código Civil de 1916, não houvesse registro do título anterior. Para Valmir Pontes, apesar da lei de registros públicos não trazer nenhuma ressalva ao princípio da continuidade, as providências que os oficiais até então tomavam nesses casos deveriam continuar a serem aplicadas. Assim, o registrador tinha que exigir a apresentação do título anterior ou sua especificação no novo título. Caso não houvesse título, o registro não poderia ser feito, exceto se apresentada sentença declaratória de usucapião. ${ }^{519}$

Dando andamento à abordagem que se fez ao longo do trabalho sobre os títulos, a nova Lei de Registros Públicos, enumera no artigo 221 todos aqueles que podem ingressar no Registro de Imóveis. Apesar de o dispositivo afirmar que "somente" os títulos arrolados serão submetidos ao registro, levando à impressão de que se trata de um rol taxativo, a própria lei no artigo 291 desmente a assertiva, ao dispor que nos casos de incorporação ou transferência de

\footnotetext{
${ }^{518}$ Esse entendimento fica claro com a situação apresentada por esse autor "Tome-se como exemplo a promessa de venda de imóvel, tratado em três números da lista (art. 167, n. I, 9, 18 e 20) para cobrir o imóvel não loteado, o condominial (apartamento) e o loteado, pois em todos eles é submetida à inscrição (registro) tanto a promessa como a subseqüente cessão ou promessa de cessão do direito aquisitivo, que devia ser subordinada à averbação. Daí decorre que, havendo sempre numerosos lotes ou apartamentos, cada qual com a sua promessa de venda, cessão de promessa ou promessa de cessão, lançadas seguidamente no livro, as promessa derivadas ficarão desgarradas das originais, perdidas na obscuridade trazida pela distância entre elas e pela mesmice da letra (R), que lhes é anteposta.

A não ser a promessa de venda, que realmente deve ser inscrita (registrada), por importar na constituição de direito real, as demais promessas, dela dependentes, devem ser averbadas, seja pela maneira indicada na lei ... seja pela maneira tradicional e corrente - de preferência esta - do lançamento à margem daquela. A verdade é que, se não houver um retorno à única e verdadeira averbação, para possibilitar pelo contato espacial, o estabelecimento de uma ligação direta entre promessas da mesma linhagem, não poderá evitar que a multiplicidade dos assentos torne inextricável a folha do livro". Registro de Imóveis(Lei n. 6.015, de 31.12.1973, com as alterações da Lei n. 6.216, de 30.6.1975). Revista dos Tribunais, São Paulo, v. 481, ano 64, p.20, 1975.

${ }^{519}$ Registro de imóveis: comentários aos arts. 167 a 288 da Lei n. 6.015 de 31 de dezembro de 1973. São Paulo: Saraiva, 1982. p. 168.
} 
bens imóveis do patrimônio público para a formação ou integralização do capital de sociedade por ações da administração indireta, ou para a formação de patrimônio de empresa pública, sirva como título hábil para o novo registro o instrumento pelo qual a incorporação ou transferência verificou-se, em cópia autêntica, ou exemplar do órgão oficial no qual foi aquele publicado.

Assim, melhor seria se a norma tivesse conceituado "título", deixando ao oficial concluir pela caracterização ou não do instrumento apresentado ao registro no caso concreto. Apenas dessa maneira seria possível garantir à matéria o aprimoramento legislativo necessária a matéria. Segundo Afrânio de Carvalho, ao optar pela taxatividade, a Lei de Registros Públicos excluiu instrumentos que outras normas admitem como suficientes para a transferência de bens, como por exemplo, todo título transmissivo de propriedade imóvel emanado do Poder Público acolhido como válido pelo decreto n. 19.924 de 27 de abril de 1931.520

Por fim, a lei manteve a previsão do Registro Torrens para imóveis rurais, repetindo dispositivos já existentes no ordenamento e ignorando todas as críticas que ao longo dos anos foram feitas ao regime.

Apesar de apresentar alguns defeitos e omissões, a lei n. 6.015 de 1973, corrigida pela de 1975, trouxe melhorias significativas para a matéria de Registro Público no que se refere ao registro imobiliário, assunto pertinente ao estudo da dissertação.

Como já apontado no item anterior, a grande inovação da lei consistiu na instituição da matrícula, ou seja, a primeira medida para a futura adoção daquele cadastro da propriedade imóvel que por tantos anos os juristas brasileiros invejaram do sistema registral alemão.

Pela previsão do art. $176, \S 1^{\circ}$, inciso I, cada imóvel teria sua própria matrícula, que seria aberta quando do primeiro registro a ser realizado na vigência da nova lei. Assim, caso o título trouxesse mais de um imóvel, seria aberta uma matrícula para cada um. Nessa matrícula, constariam todas as informações sobre o imóvel, suas características e confrontações,

${ }^{520}$ Registro de Imóveis (Lei n. 6.015, de 31.12.1973, com as alterações da Lei n. 6.216, de 30.6.1975). Revista dos Tribunais, São Paulo, v. 481, ano 64, p. 26, 1975. 
individualizando-o. Para obter todos esses dados, o oficial deveria analisar o título apresentado e a última transcrição do imóvel (art. 228). Quando esses dados eram insuficientes, impedindo uma clara identificação do bem, o oficial negava-se a realizar o registro, cabendo ao interessado buscar o meio judicial competente para obtê-lo.

Com a matrícula, adotou-se também o princípio da folha única, fazendo com que cada folha do livro de registro fosse destinada a um único imóvel. Assim, as buscas eram sensivelmente facilitadas, com a concentração dos dados em um único local e as informações não precisavam ser repetidas de forma idêntica em livros diversos. ${ }^{521}$

Ressalta-se que a instituição da matrícula consistiu apenas em um aprimoramento técnico, não representando alteração na presunção do registro que continuou relativa. Assim, segundo Valmir Pontes, apesar de ser correto o entendimento que a criação da matrícula visou estabelecer no Brasil, em um futuro distante, um sistema similar ao alemão, continua sendo possível retificar ou anular os registros. ${ }^{522}$ Em outras palavras, o desejo expresso por AFRÂNIO De Carvalho em seu projeto de 1969, de adotar no Brasil o princípio da fé pública registral, mais uma vez foi afastado, assim com a instituição de um cadastro.

Perceba-se que a matrícula não é o mesmo que cadastro. O cadastro imobiliário tem como característica fundamental o fato de ser elaborado com base em informações emitidas apenas por órgãos oficiais, ou seja, a Prefeitura, o Fisco entre outros. Já a matrícula é elaborada com base nos dados presentes no título apresentado pelo interessado e nos dados contidos no assento, ou seja, informações fornecidas pelo próprio particular. Nos últimos anos, a diferenciação entre cadastro e matrícula tem-se estreitado. De um lado, o oficial vem exigindo uma série de documentos oficiais que comprovem os dados apresentados pelos contratantes, de outro, a previsão legal do georreferenciamento para imóveis rurais tem

\footnotetext{
${ }^{521}$ Como destaca Gilberto Valente da Silva, antes da nova lei, ao se registrar uma escritura de compra e venda com pacto adjeto de hipoteca era necessário primeiro registrar a escritura no livro 3 das Transcrições das Transmissões e depois, o pacto no livro 2 destinado ao Registro Geral de Hipoteca. Em ambos os livros havia uma coluna destinada as características do imóvel e confrontações, o que fazia com que houvesse uma mera repetição em um livro e outro. Com a lei de 1973, abaixo da matricula, em uma mesma folha, era feito primeiro a escritura de transmissão e depois o pacto adjeto de hipoteca. As modificações introduzidas na nova lei de registros públicos. In: Cenneviva, Walter (Org.). A lei de Registros Públicos e o Direito Imobiliário. São Paulo: Associação dos Advogados de São Paulo, 1976. p. 71.

${ }^{522}$ Registro de imóveis: comentários aos arts. 167 a 288 da Lei n. 6.015 de 31 de dezembro de 1973. São Paulo: Saraiva, 1982. p. 66.
} 
tornado muito mais precisa a delimitação desse bem (art. 225, $\S 3^{\circ}$ da Lei de Registros Públicos).

Segundo Ari Álvares Pires Neto, o georreferenciamento consiste em uma nova maneira de descrever os imóveis rurais, a partir de dados geodésicos de seus vértices obtidos por satélite ${ }^{523}$. Assim, com informações técnicas precisas é mais fácil estabelecer os limites e dimensões dos imóveis rurais. ${ }^{524}$

Mesmo com as cautelas tomadas pelo registrador e as novas tecnologias visando a maior identificação entre o assento e a realidade física do bem, não há como negar que a matrícula da maneira como regulada na lei brasileira, e devido ao seu pouco tempo de existência, está longe de poder ser igualada ao cadastro alemão.

Interessante que, se por um lado a Lei de Registros Públicos, ao instituir a matrícula aproximou o sistema brasileiro do modelo cadastral alemão, por outro afastou-o desse regime, ao admitir expressamente e sem ressalvas que o registro baseado em título nulo ou anulável seja cancelado diante de determinação judicial. Essa disposição, ao não ressalvar os direitos de terceiros adquirentes de boa-fé, concretiza a segurança do direito de propriedade em detrimento da segurança do comércio, desviando o sistema registrario pátrio do alemão.

Apesar de todas as correções apresentadas pela lei n. 6.216 de 1975 ao texto original de 1973, elas foram vistas como insuficientes por AfrÂNIO CARVALHO. O autor, que já havia apontado erros na primeira versão da lei, não poupou críticas às alterações, afirmando que os dispositivos destinados ao Registro de Imóveis haviam abandonado a tradição e o objetivo do registro, desviando a instituição do caminho do progresso que ela vinha seguindo. O motivo dessa mudança de direção teria decorrido da grande vontade do legislador de modernizar os serviços registrais, que o levou a se descuidar da própria razão de ser do registro, ou seja, daquelas estruturas que protegem os direitos inscritos e que levam o público a confiar na instituição. ${ }^{525}$

\footnotetext{
${ }^{523}$ Georreferenciamento e retificação extrajudicial de imóveis urbanos e rurais. Revista de Direito Imobiliário, São Paulo, n. 58, ano 28, p. 60, jan. e jun. 2006.

${ }^{524} \mathrm{O}$ novo sistema de descrição ainda é pouco abrangente. Segundo informações obtidas na página eletrônica do INCRA, até 19 de janeiro de 2009, apenas 11.842 imóveis tinham sua identificação georreferenciada e certificada

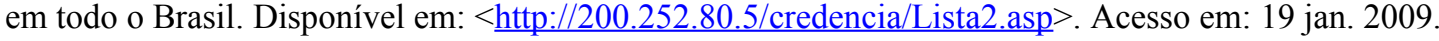


Bem menos crítico mostrou-se Walter Ceneviva, para quem a nova lei trazia modificações (como a matrícula e novas formas de realização do registro) que possivelmente levariam a um conceito de registro "seguro, como livre de risco". Para esse autor, ao levar-se um ato ao registro ele era munido de "característicos de segurança" para o titular, que tinha garantido o direito sobre a coisa, e para terceiros, que podiam obter informações sobre a situação jurídica de seu interesse, em relação a bens imóveis e pessoas. Esses "característicos de segurança" eram resultado de uma rigorosa particularização do bem e da precisa qualificação do titular do imóvel e de detentores de créditos sobre ele, informações exigidas para a constituição da matrícula. ${ }^{526}$

Apesar dos elogios de Ceneviva, não há como ignorar que a Lei deixou a desejar em alguns pontos. No entanto, afirmar, como fez Afrânio de Carvalho, que ela seja um retrocesso não condiz com as inovações que, apesar de tímidas, caracterizaram a nova Lei. Na verdade, manteve-se a tradição de alterações pequenas e graduais que acompanharam a legislação registrária brasileira desde os seus primórdios e afastou-se a possibilidade de rupturas, como teria ocorrido com a adoção do Anteprojeto apresentado por AfRÂNIO DE Carvalho em 1969.

\subsection{Antecedentes do Código Civil de 2002}

Concomitante às discussões sobre possíveis alterações na Lei de Registros Públicos, ocorreram iniciativas de reforma do Código Civil de 1916. Logo após sua promulgação, o texto legislativo passou a sofrer modificações e inclusões por leis esparsas que, em muitos casos, não acompanhavam o espírito do código. Como já abordado no item 4.1, as tristes experiências sofridas pelo mundo, inclusive pelo Brasil, levaram à mudança gradativa na maneira de se regular as relações jurídicas, buscando-se conciliar os interesses individuais com os da coletividade.

\footnotetext{
${ }^{525}$ Registro de Imóveis (Lei n. 6.015, de 31.12.1973, com as alterações da Lei n. 6.216, de 30.6.1975). Revista dos Tribunais, São Paulo, vol. 481, ano 64, p.18, 1975.

${ }^{526}$ Apontamentos sobre o novo direito imobiliário brasileiro. 1977. 92f. Dissertação apresentada como exigência para obtenção do grau de Mestre em direito à Comissão Julgadora da Pontifícia Universidade Católica de São Paulo - Área do Direito Civil.
} 
A primeira vez que se cogitou reformar o Código Civil foi em 1931, resultado da iniciativa do governo criado após o golpe de 1930 de modernizar toda legislação nacional. No campo do direito civil foi formada a primeira sub-comissão legislativa (decreto n. 19. 684 de 10 de fevereiro de 1931), composta por Clóvis Bevilaqua, Eduardo Espínola e Alfredo Bernardes. O intuito do grupo não era substituir o Código Civil vigente, mas sim atualizá-lo, integrando-o com a legislação posterior à sua publicação, corrigindo falhas e alterando alguns institutos que não mais atendiam as necessidades sociais. Apesar de apresentadas algumas emendas, o trabalho não foi concluído. ${ }^{527}$

Dez anos mais tarde, outro grupo de juristas foi organizado para a empreitada. A Comissão composta por Orozimbo Nonato, Philadelpho Azevedo e Hahneman Guimarães entendeu que o campo das Obrigações era o que mais havia sofrido modificações e, portanto, era o que precisava de revisão urgente. Ademais, acreditavam que ao se centrarem na atualização das relações obrigacionais, resolveriam o problema da reforma do direito mercantil, tão indispensável naquele momento. Após a revisão do Livro referente às Obrigações, a Comissão planejava modernizar as outras matérias civis, acreditando ser totalmente possível substituir o Código de Direito Privado, por vários códigos que tratariam separadamente das obrigações, da propriedade e na mesma obra da família e sucessões. ${ }^{528}$

Interessante como os membros da Comissão defenderam, em 1941, o que seria os primórdios dos "códigos temáticos", tão sustentados por ANTÔNIO JUNQUeIRA DE AzEvedo ${ }^{529}$ às vésperas da publicação do novo Código Civil. Em outras palavras, entendiam que a vasta matéria de direito civil deveria ser revisada por grupos de assunto, cada qual dando origem a uma lei distinta.

Outra inovação da Comissão nomeada para revisar o Código Civil de 1916, consistiu na proposta de reduzir ou mesmo eliminar a Parte Geral, tendo em vista que ela “dificultava o ensino e a apreensão imediata do sentido das normas jurídicas”. Além de dispor sobre preceitos de aplicação privativa ou predominante de certas matérias, a Parte Geral traz ${ }^{527}$ Espinola, Eduardo e Espinola Filho, Eduardo. Tratado de Direito Civil Brasileiro. Rio de Janeiro: Freitas Bastos, 1939. p. 554 e 555/vol.II.

${ }^{528}$ Brasil. Código Civil: anteprojetos. Brasília: Senado Federal, Subsecretaria de Edições Técnicas, 1989. p. 55 e 56/vol.1.

${ }^{529}$ O direito pós-moderno e a codificação. Revista de Direito do Consumidor, São Paulo, n. 33, ano 9, p.128, jan.-mar. 2000. 
termos que muitas vezes acabavam por conflitar com os conceitos desenvolvidos pela doutrina em evolução. ${ }^{530}$

No entanto, a tentativa não obteve êxito, uma vez que a Comissão centrava-se na análise do direito obrigacional, e havia necessidade de uma revisão que englobasse todo o código, disciplinando as novas relações sociais que surgiam. ${ }^{531}$

Como essa Comissão apenas chegou a apresentar a proposta de revisão do Código das Obrigações, não houve a elaboração de qualquer dispositivo que tratasse da transmissão da propriedade imóvel pelo registro do título.

Entretanto, havia artigos referentes à escritura pública, que deveria ser levada a registro para a transferência da propriedade imóvel. Nas disposições gerais do Título I

referente à "Constituição das Obrigações" no Capítulo I sobre a "Declaração de vontade" ficou definido que a escritura pública seria essencial à validade da declaração nas obrigações que visassem a constituição ou transferência de direitos reais sobre imóveis de valor superior a um conto de réis, salvo as exceções expressas (art. $\left.4^{\mathrm{o}}\right) .{ }^{532} \mathrm{O}$ dispositivo manteve a quantia exigida para a obrigatoriedade de escritura pública prevista no artigo 237 da lei n. 4.857 de 1939 (alterado pelo decreto n. 5.318 de 1940).

Assim, nos demais casos, era suficiente o instrumento particular, além é claro daquelas hipóteses em que a transcrição era feita com base em outros títulos como os atos autênticos de países estrangeiros (com caráter de instrumento público, legalizados e traduzidos no idioma nacional) e as cartas de sentença, mandados, formais de partilha e certidões extraídas de processo, conforme previa as alíneas "c" e "d" do artigo 237 da lei n. 4.857 de 1939.

Em 1961, houve nova tentativa de atualização do Código Civil, mas dessa vez envolvendo toda a matéria nele prevista. O projeto inovava ao buscar a unificação do Direito

\footnotetext{
${ }_{530}$ Brasil. Código Civil: anteprojetos. Brasília: Senado Federal, Subsecretaria de Edições Técnicas, 1989, p. 56/vol.1.

${ }^{531}$ Brasil. Novo Código Civil. Exposição de Motivos e texto sancionado. Brasília: Senado Federal. Secretaria Especial de Editoração e Publicações, 2002. p. 24.

${ }^{532}$ Brasil. Código Civil: anteprojetos. Brasília: Senado Federal, Subsecretaria de Edições Técnicas, 1989, p.15/vol.1.
} 
Privado com a elaboração de dois códigos, o Civil, que regeria as relações de propriedade, família e sucessão, e o das Obrigações, que trataria não só das obrigações civis, mas também das comerciais.

Oscar Pedroso d'Horta, Ministro da Justiça do Governo de Jânio Quadros, convidou Orlando Gomes para elaborar o Anteprojeto de Código Civil que serviria como base aos trabalhos de uma Comissão que se encarregaria do Projeto definitivo. ${ }^{533}$ Já o Código das Obrigações foi confiado a Caio Mário da Silva Pereira, que teria a colaboração de Sylvio Marcondes, Theophilo de Azevedo Santos e Nehemias Gueiros. ${ }^{534}$

Com a renúncia do presidente Jânio Quadros, o Serviço de Coordenação de Reforma dos Códigos sofreu pequeno abalo, o que interrompeu por um breve período a elaboração dos projetos. Já em 1962, o novo Governo sinalizou por meio de seu Ministro da Justiça, João Mangabeira, o interesse em manter os trabalhos de reforma dos Códigos. Por meio de contrato de locação de serviços, Orlando Gomes comprometeu-se a entregar o Anteprojeto no prazo de 4 meses, o que foi rigorosamente cumprido em 31 de março de 1963.535

Na elaboração do Anteprojeto de Código Civil, Orlando Gomes buscou auxílio nas legislações estrangeiras, trazendo novidades ao ordenamento brasileiro. Uma delas, de criação suíça, consistiu em iniciar todos os artigos do código civil com uma epígrafe, uma frase que resumisse o conteúdo do dispositivo em poucas palavras, a fim de tornar o texto legislativo mais claro. ${ }^{536}$ Assim, por exemplo, o artigo 421 que dispunha sobre a necessidade da transcrição para a transferência de titularidade de bem imóvel tinha como epígrafe "Eficácia da transcrição", 537

Outra inovação, esta amparada na doutrina brasileira e estrangeira, foi a eliminação da parte geral. Seus preceitos passaram a ser regulados ao lado dos institutos que

${ }^{533}$ Gomes, Orlando. A Reforma do Código Civil. Salvador: Publicações da Universidade da Bahia, 1965. p. 1.

${ }_{534}^{53}$ Roque, Sebastião José. História do Direito. São Paulo: Ícone, 2007. p. 292.

${ }^{535}$ Gomes, Orlando. A Reforma do Código Civil. Salvador: Publicações da Universidade da Bahia, 1965. p. 2.

${ }_{536}$ Idem. Memória Justificativa de Reforma do Código Civil. Rio de Janeiro: Departamento de Imprensa Nacional, 1963. p. 20.

${ }^{537}$ Brasil. Anteprojeto de Código Civil. Apresentado ao Exmo. Sr. João Mangabeira, Ministro da Justiça e Negócios Interiores, em 31 de março de 1963, pelo prof. Orlando Gomes. Rio de Janeiro: Departamento de Imprensa Nacional, 1963. p. 51. 
mais os utilizavam e sem que houvesse muito "doutrinarismo" e "formulações abstratas" como defendia Gomes. Para o autor, a obra legislativa não devia conter definições e classificações em suas disposições normativas, cabendo a doutrina abordar estas matérias. ${ }^{538}$

Quanto ao conteúdo do Anteprojeto, a transmissão da propriedade imóvel pelo registro do título veio disciplinada em seu terceiro capítulo. No geral, manteve os dispositivos do Código Civil de 1916, sendo poucas as alterações ou inclusões. Primeiramente, previu expressamente o princípio da continuidade, ao dispor que nenhuma transcrição ou inscrição poderia ser feita sem o prévio registro do título anterior. Em segundo lugar, admitiu que qualquer interessado pudesse registrar o título, não sendo necessário novo consentimento do alienante (art. 425) Para Orlando Gomes, esse último dispositivo buscava evitar uma injustiça que o Código antigo deixava em aberto. A injustiça acontecia quando, logo após a elaboração da escritura ou contrato de transmissão da propriedade imóvel, e antes da realização de seu registro, o alienante morria, colocando em dúvida a possibilidade ou não da transcrição. Como ainda não havia ocorrido a mudança da titularidade e a sucessão era aberta no momento do óbito, tudo levava à inclusão do bem na herança deixada pelo de cujus. Para o autor, como o ato de registro não exigia novo consentimento do alienante, o adquirente poderia realizar a transcrição mesmo depois da morte do outro contratante. ${ }^{539}$

O Anteprojeto ainda tentava solucionar um debate antigo, que buscava desvendar a extensão do artigo 859 do Código Civil, ou seja, a adoção pelo sistema registrário brasileiro do princípio da fé pública e da força probante do registro. Segundo OrLANDO GOMES, a previsão de dois artigos visava justamente impedir qualquer controvérsia acerca da eficácia da transcrição ${ }^{540}$. Os dispositivos eram os seguintes:

“Art. 428. Presunção de Propriedade - Até prova em contrário, o imóvel pertence àquele em cujo nome estiver inscrito ou transcrito."

\footnotetext{
${ }^{538}$ Memória Justificativa de Reforma do Código Civil. Rio de Janeiro: Departamento de Imprensa Nacional, 1963. p. 14 e 15.

${ }_{539}$ Memória Justificativa de Reforma do Código Civil. Rio de Janeiro: Departamento de Imprensa Nacional, 1963. p. 79 e 80.

${ }^{540}$ Ibidem., p. 79.
} 
“Art. 429. Transcrição de Título Inválido - Se o título de transmissão fôr inválido, será nula a transcrição." ${ }^{541}$

Assim, o valor do registro seria limitado, dependeria da validade do título e admitiria a correção da transcrição quando se provasse que aquele que aparecia como titular no assento registrário não era o real proprietário. Em outras palavras, a presunção de domínio era sempre relativa. Priorizava-se o direito de propriedade do titular do domínio, mesmo que por qualquer engano no assento, ou nulidade do título, terceiro de boa-fé tivesse adquirido o bem.

Não parece que nesse aspecto o Anteprojeto tenha abandonado o excesso de individualismo do Código de 1916 e, conseqüentemente, a cega proteção da propriedade. Apesar de Orlando Gomes ter sinalizado que o tempo de predominância do individualismo tinha sido superado, e que havia chegado o momento de conciliá-lo com o interesse da coletividade, não era bem isso que se via nos dispositivos referentes à transmissão da propriedade pela transcrição. Uma legislação que estivesse realmente comprometida em conciliar os interesses do indivíduo e da sociedade, deveria apresentar um sistema registrario que também buscasse a harmonia entre a segurança do direito de propriedade e da segurança do comércio. No entanto, diferentemente do que a justificativa do anteprojeto indicava, Orlando Gomes conservou as mesmas bases do Código Civil de 1916, não criando nem mesmo figuras que pudessem aproximar o sistema brasileiro de um regime cadastral.

Quanto aos títulos que pudessem ser levados a registro, nenhum dispositivo tratou sobre o assunto, uma vez que por determinação do governo o Anteprojeto de OrLANDo Gomes não incluiu a matéria referente às Obrigações. Coube a CAIO MÁRIO apresentar o Anteprojeto de Código das Obrigações referente ao negócio jurídico, obrigações em geral, contratos e outros títulos e, conseqüentemente, tratar sobre os casos em que se exigia a escritura pública. ${ }^{542}$

$\overline{541}$ Brasil. Anteprojeto de Código Civil. Apresentado ao Exmo. Sr. João Mangabeira, Ministro da Justiça e Negócios Interiores, em 31 de março de 1963, pelo prof. Orlando Gomes. Rio de Janeiro: Departamento de Imprensa Nacional, 1963. p. 52.

${ }^{542}$ A parte do Anteprojeto de Código de Obrigações relativa a sociedades e exercício da atividade mercantil (1964) ficou sob responsabilidade de Sylvio Marcondes. E aquela referente aos títulos de créditos coube a Theophilo de Azeredo Santos (1964). Brasil. Código Civil: anteprojetos. Brasília: Senado Federal, Subsecretaria de Edições Técnicas, 1989. p. 137 e 243/vol.3. 
Pelo Anteprojeto a escritura pública era essencial à validade da declaração de vontade nas obrigações que visassem à constituição ou transferência de direitos reais sobre imóveis de valor superior a duas vezes o mais elevado salário mínimo vigorante no País, salvo previsão legal em contrário. Era indispensável nos casos em que a parte era incapaz e, quando ela não soubesse ou não pudesse escrever (art. $\left.8^{\circ}\right){ }^{543}$ A substituição de um valor fixo, como previsto no Anteprojeto de 1941, por um valor móvel do negócio jurídico para a exigência de escritura pública era para CAIO MÁrIO “convinhável” uma vez que a atualização de um código era difícil e demorada. Assim, atrelando o valor ao salário mínimo, o autor acreditava que a quantia representaria por mais tempo o que havia sido imaginado pelo legislador. ${ }^{544}$

Assim, tentava-se adequar as exigências da lei às necessidades sociais, desonerando negócios jurídicos de baixo valor que poderiam ser registrados com a simples apresentação de um instrumento particular.

Quanto ao Anteprojeto de ORLANDO Gomes, com apenas pequenas alterações relativas à transferência da propriedade imóvel ele foi enviado em 13 de maio de 1963 à Comissão Revisora que, após 43 sessões, finalizou o trabalho, encaminhando-o ao Ministro da Justiça Milton Campos (governo do presidente Castello Branco) em 28 de setembro de $1964 .^{545}$

A Comissão Revisora, composta por Orlando Gomes, Orosimbo Nonato e Caio MARIO, realizou pequenas alterações nos artigos relativos à transmissão da propriedade imóvel pelo registro do título e, essencialmente, quanto à redação dos dispositivos. Um artigo foi eliminado, o que tratava sobre a não exigência de ação direta para invalidar registro nulo, e outro passou ao status de parágrafo único, contabilizando um total de 10 artigos sobre a matéria, dos 12 do anteprojeto de 1963.

Os artigos já transcritos acima depois de revistos passaram a seguinte redação:

\footnotetext{
${ }_{543}$ Brasil. Código Civil: anteprojetos. Brasília: Senado Federal, Subsecretaria de Edições Técnicas, 1989. p. 14/vol.3.

${ }^{544}$ Brasil. Código Civil: anteprojetos. Brasília: Senado Federal, Subsecretaria de Edições Técnicas, 1989. p. 116 e 117/vol.3.

${ }^{545}$ Brasil. Código Civil: anteprojetos. Brasília: Senado Federal, Subsecretaria de Edições Técnicas, 1989. p. 435/ vol.2.
} 
Art. 421. Presunção de propriedade - O imóvel presume-se pertencer, até prova em contrário, àquele em cujo nome estiver transcrito.

Art. 422. Transcrição de título inválido - A transcrição não convalesce título inválido. ${ }^{546}$

O Anteprojeto revisto enviado à Câmara dos Deputados pela mensagem presidencial n. 804 de 12 de outubro de 1965 teve sua tramitação interrompida por solicitação do próprio Presidente da República, em 23 de junho de 1966. Castello Branco achava necessário reexaminar o assunto, o que frustrou mais uma vez a tentativa de reforma do Código Civil. ${ }^{547}$

No entanto, no pequeno tempo em que foi debatido na Câmara, o deputado Celestino Filho propôs emendas alterando e incluindo artigos referentes à aquisição da propriedade imóvel. Pela emenda 52 incluía entre os modos de aquisição "a matrícula no registro Torrens" e pela emenda 53 propunha uma seção destinada a este sistema, dispondo entre outras coisas sobre a possibilidade da inscrição nesse regime não só de imóveis rurais, mas também de urbanos. Para o deputado a incorporação desse modelo ao Código Civil era fundamental, uma vez que o registro Torrens vinha se mostrando de grande relevância ao país por garantir segurança absoluta de domínio, evitando inúmeras demandas judiciais. ${ }^{548}$

Interessante como apesar das críticas contínuas e intensas ao Registro Torrens havia sempre aqueles que defendiam sua utilidade e importância, lutando pela sua manutenção no ordenamento brasileiro. Mais uma vez a previsão do Registro Torrens surgia como a maneira mais fácil de se resolver o problema da insegurança nas transmissões da propriedade imóvel, já que facultativo. Lembre-se que nesta época ainda não havia nenhum projeto de lei que previsse a adoção de um cadastro imobiliário, uma vez que AfrÂNIO de CARVAlHo somente apresentou seu anteprojeto em 1969.

Como já foi visto, o Anteprojeto de Código Civil de 1965 e as emendas foram abandonados por solicitação do Presidente da República, sendo a atualização da lei civil

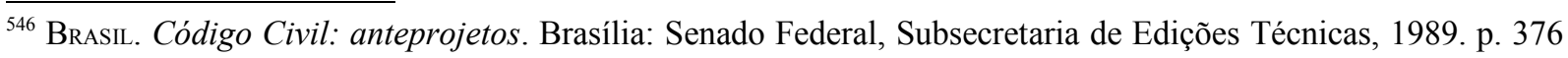
e 377/vol.2.

${ }^{547}$ Brasil. Código Civil: anteprojetos. Brasília: Senado Federal, Subsecretaria de Edições Técnicas, 1989. p. 144/ vol.4.

${ }^{548}$ BRAsil. Código Civil: anteprojetos. Brasília: Senado Federal, Subsecretaria de Edições Técnicas, 1989. p. 180 a $183 /$ vol.4. 
postergada mais uma vez. O mesmo aconteceu com o Anteprojeto do Código das Obrigações que, após breve passagem pela Câmara dos Deputados, teve sua tramitação interrompida, em 5 de setembro de 1967 , para reexame do assunto. ${ }^{549}$

Apenas na quarta tentativa de reforma do Código Civil, e após anos de discussão, obteve-se o êxito esperado. Em 23 de maio de 1969, foi criada a Comissão Revisora e elaboradora do Código Civil, que composta de seis juristas sob a supervisão de Miguel Reale, prepararam um novo Anteprojeto, ficando a parte relativa ao "Direito das Coisas" sob responsabilidade de Erbert Chamoun. ${ }^{550}$

Três anos após a sua criação, em 1972, a Comissão entregou o Anteprojeto de Código Civil ao Ministro da Justiça Alfredo Buzaid acompanhado de uma apresentação, na qual Miguel Reale, além de apontar os principais aspectos de cada livro que compunha a obra, indicava as diretrizes fundamentais, o processo de trabalho, a estrutura e a linguagem do Anteprojeto.

Entre as diretrizes, destacava-se a unificação do Código Civil, não se acolhendo a iniciativa de 1941 e 1963 de separar a matéria referente às obrigações, divisão que parecia para os novos projetistas injustificada. Essa atitude não era totalmente inesperada, principalmente porque a separação do livro das obrigações já havia sido severamente criticada em 1963 pelo próprio OrLando Gomes, para quem o objetivo da cisão, ou seja, a unificação do direito privado poderia ser obtida conservando-se a unidade do código. Ademais, o autor ressaltava que a separação poderia gerar divergências entre o Código das Obrigações e o Código Civil, principalmente pelo fato de que os projetos haviam sido confiados a juristas diferentes. Por fim, haveria "quebra" da sistemática, o que dificultaria uma maior determinação do conteúdo dos institutos e das relações que se estabelecem entre as várias figuras jurídicas. ${ }^{551}$

Como outra diretriz fundamental do Anteprojeto, sobressaía a preservação da Parte Geral que havia sido eliminada pelos projetistas de 1963. Para a novo grupo de juristas

\footnotetext{
${ }^{549}$ BRASIL. Código Civil: anteprojetos. Brasília: Senado Federal, Subsecretaria de Edições Técnicas, 1989. p. 444/ vol.4.

${ }^{550}$ Roque. Sebastião José. História do Direito. São Paulo: Ícone, 2007. p. 292.

${ }^{551}$ Memória Justificativa de Reforma do Código Civil. Rio de Janeiro: Departamento de Imprensa Nacional, 1963. p. 16 e 17.
} 
responsáveis pela atualização do Código Civil, não era possível ignorar a tradição jurídica brasileira de adoção da Parte Geral, para assumir modelos estrangeiros, distantes da realidade pátria. Ademais, a existência deste livro impedia a repetição desnecessária de preceitos jurídicos ao longo do Código, que por serem reproduzidos em contextos distintos poderiam se tornar objetos de inúmeras divergências. ${ }^{552}$

Ainda como orientação aos membros da Comissão, aproveitou-se a idéia já adotada no Anteprojeto do Código das Obrigações de 1941 e no Anteprojeto de Código Civil de 1963 de reunir no mesmo texto normativo as obrigações civis e mercantis. A partir de então, as atividades negociais e empresarias deveriam ser vistas como um desdobramento natural do Direito das Obrigações. ${ }^{553}$

Não foi essa a única contribuição dos Anteprojetos anteriores. Na enumeração das

diretrizes fundamentais, ReAle deixava claro que esses trabalhos tinham sido utilizados na elaboração do futuro Código, assim como todos os estudos e críticas levantados quando de suas publicações, aproveitando-se todo o esforço já despedido até então sobre a matéria. ${ }^{554}$

No relativo à transmissão da propriedade imóvel pelo registro do título, não foram aproveitados todos os artigos do Anteprojeto de Orlando Gomes. A Seção I "Da aquisição pela transcrição do titulo" ficou mais concisa, trazendo apenas três artigos, no lugar dos dez que tratavam sobre a matéria em 1964. O Anteprojeto de 1972 fixou-se unicamente na importância da transcrição, sua eficácia e possibilidade de retificação. Tentando evitar dúvidas quanto aos efeitos do registro previu:

“Art. 1.442. Se o teor da transcrição não exprimir a verdade poderá o interessado reclamar que a retifique, ou anule.

Parágrafo único. Cancelada a transcrição, poderá o proprietário reivindicar o imóvel, independentemente da boa-fé, ou do título do terceiro adquirente”.

Dessa maneira, se aprovado o dispositivo do Anteprojeto nesses termos, ficaria clara a adoção pelo sistema imobiliário brasileiro do princípio da presunção relativa de

\footnotetext{
${ }^{552}$ Brasil. Anteprojeto de Código Civil. Brasília. Departamento de Imprensa Nacional, 1972. p. 14.

${ }^{553}$ Brasil. Anteprojeto de Código Civil. Brasília. Departamento de Imprensa Nacional, 1972. p. 8.

${ }^{554}$ Brasil. Anteprojeto de Código Civil. Brasília. Departamento de Imprensa Nacional, 1972. p. 8.
} 
domínio, mesmo diante de terceiro adquirente de boa-fé, o que comprovaria a tendência histórica de prevalência da segurança do direito de propriedade em detrimento da segurança do comércio.

O Anteprojeto não foi levado à análise do Congresso Nacional antes de serem feitas modificações com base em críticas e sugestões apresentadas por diversos setores da sociedade logo após sua divulgação.

REALE ressaltou diversas vezes o papel fundamental da sociedade na elaboração do projeto de Código Civil. Responsável pela "ordenação sistemática da matéria”, afirmou ter organizado o texto legal e realizado as modificações pertinentes, com base nos Anteprojetos apresentados por cada um dos juristas contratados e pelas sugestões recebidas por diversos grupos sociais e por pessoas comuns. ${ }^{555}$

Apesar do supervisor da reforma do Código Civil destacar a importância que a Comissão conferiu às opiniões de vários setores da sociedade, não foi essa a impressão que teve Caio Mário. Para esse autor, o Anteprojeto de Código Civil não foi alvo de muitas criticas, pois era de conhecimento comum a má vontade dos membros da Comissão em acatar qualquer sugestão. ${ }^{556}$

Respondendo diretamente à declaração de CAIO MÁrio, Reale afirmou que diferentemente do que dizia o jurista da Guanabara, as críticas e sugestões haviam sido muitas, de juristas, órgão oficiais, entidades de classe, e outros, o que demonstrava o interesse que o trabalho de atualização da lei civil havia despertado nos diversos grupos. Ademais, a preocupação da Comissão em ouvir a sociedade ficava clara com a ampla divulgação do Anteprojeto e pela participação freqüente de seus membros em debates e seminários sobre a matéria. Por fim, o autor destacava que não faltava à Comissão "probidade científica para apreciar essa colaboração de valor inestimável". ${ }^{557}$

\footnotetext{
${ }_{555}$ Brasil. Anteprojeto de Código Civil. Brasília. Departamento de Imprensa Nacional, 1972. p. 10 e 11.

${ }^{556}$ As declarações de Caio Mario da Silva Pereira foram obtidas no texto publicado por Miguel Reale no jornal "O Estado de São Paulo" nos dias 30 e 31 de dezembro de 1972 e 5, 7 e 9 de janeiro de 1973.

${ }^{557}$ Declaração do Prof. Miguel Reale, na qualidade de Supervisor da "Comissão Elaboradora e Revisora do Código Civil", em resposta à entrevista do Prof. Caio Mario da Silva Pereira, publicada em "O Estado de São Paulo", de 20, 21 e 23 de dezembro de 1972. Essas declarações foram publicadas pelo mesmo jornal, nos dias 30 e 31 de dezembro de 1972 e 5, 7 e 9 de janeiro de 1973.
} 
Independentemente do uso ou não pelos projetistas das sugestões de vários setores da sociedade, não há como negar que o Anteprojeto publicado e amplamente divulgado, em 18 de junho de 1974, apresentava diferenças se comparado ao de $1972 .{ }^{558}$

Nas considerações, que antecederam o Anteprojeto de 1974, foram acrescentadas quatro diretrizes aquelas indicadas em 1972. Entre elas destacam-se duas: a que previa a inclusão, no futuro Código Civil, de institutos novos almejados pela sociedade, como matérias tratadas por legislações civis publicadas após 1916 e modelos jurídicos desenvolvidos pela jurisprudência, e aquela diretriz que alertava os codificadores sobre a necessidade de diminuir as formalidades que oneravam excessivamente certas figuras jurídicas, como a exigência de escritura pública em casos nos quais o instrumento particular registrado era suficiente.

Quase um ano depois de sua divulgação, o Anteprojeto foi encaminhado ao Congresso Nacional pela mensagem presidencial n. 160 de 10 de junho de 1975, onde seria mais uma vez objeto de debates e aperfeiçoamentos.

Segundo Reale, a atualização e o aprimoramento do projeto de Código Civil continuaram durante todo trâmite legislativo, o que tornou errônea a afirmação de alguns juristas de que a nova legislação civil por estar vinculada a um projeto de 1975, teria nascido velha. ${ }^{559}$

Sem dúvida, durante a passagem pelas Casas legislativas, o projeto sofreu alterações que visavam adequá-lo às necessidades sociais do momento. $\mathrm{Na}$ Câmara dos Deputados foram oferecidas 1.063 emendas ao projeto que continha 2.009 artigos. Não foram criados empecilhos no relativo à sua estrutura, ou seja, à previsão de uma Parte Geral e a unificação das obrigações civis e mercantis. Após o exame de cada uma das emendas, alguns dispositivos do projeto foram modificados, dando-se relevância maior às mudanças de conteúdo do que de redação. ${ }^{560}$

\footnotetext{
${ }_{558}$ Brasil. Novo Código Civil. Exposição de motivos e texto sancionado. Brasília: Senado Federal. Secretaria Especial de Editoração e Publicações, 2002. p. 32.

${ }^{559}$ História do Novo Código Civil. São Paulo: Tribunais, 2005. p. 25.

${ }^{560}$ Deputado Ernani Satyro. Parecer do Relatório Geral na Câmara dos Deputados. Reale, Miguel; Costa, Judith Martins (coord.). História do Novo Código Civil. São Paulo: Tribunais, 2005. p. 118, 119 e 121.
} 
Foi apenas em 1984 que a Câmara dos Deputados aprovou a redação final do Projeto, enviando-o em 12 de junho do mesmo ano para a análise do Senado Federal. Já nos primeiros três meses, 331 emendas foram apresentadas pelos Senadores, o que levou à impressão de que o processo de análise e aprovação nessa Casa seria mais rápido. No entanto, não foi o que aconteceu. $\mathrm{O}$ estudo do projeto acabou prolongando-se por anos, em grande parte pelo momento histórico de democratização por que passava o país. Com a convocação da Assembléia Nacional Constituinte, os senadores acharam mais correto esperar a publicação da nova Carta Magna, uma vez que os dispositivos constitucionais poderiam alterar significativamente as bases da legislação nacional. ${ }^{561}$

No entanto, a Constituição de 1988 não trouxe modificações que justificassem a paralisação do trâmite legislativo do projeto de Código Civil. A grande alteração ocorreu no Direito de Família, no qual a Constituição acatou a emenda que o senador Nelson Carneiro já havia formulado para o projeto do novo Código Civil, de prever a igualdade entre os cônjuges e entre os filhos. ${ }^{562}$ Assim, em nada adiantou esperar a publicação da Carta Magna; na realidade, a suspensão dos trabalhos legislativos só atrasou ainda mais a aprovação de uma lei que a sociedade tanto almejava.

Foi apenas em 1995 que o projeto retornou à sua tramitação no Senado. As 331 emendas foram analisadas, abrindo-se a possibilidade de juristas e entidades manifestarem-se sobre as diversas matérias, o que consistiu um grande auxilio aos congressistas no aprimoramento dos dispositivos. Algumas emendas aditivas foram apresentadas pelo Relator Geral Josaphat Marinho, o que foi fundamental para a atualização do projeto. ${ }^{563}$

Realizada a discussão no Plenário, a redação final foi aprovada, sendo o projeto enviado à Câmara dos Deputados, em 16 de dezembro de 1997, para a ratificação das novas emendas oferecidas pelo Senado. Em regra, os deputados deveriam analisar unicamente as modificações introduzidas pelo Senado Federal; no entanto, diante do fato de que o projeto já tramitava por três legislaturas e havendo receio de que o Código Civil contrariasse em algum ponto a Constituição Federal recém promulgada ou mesmo não incluísse preceitos legais ${ }^{561}$ Ibidem., p. 30 .

${ }^{562}$ Reale, Miguel. In: Reale, Miguel ; Costa, Judith Martins (coord.). História do Novo Código Civil. São Paulo: Tribunais, 2005. p. 30 e 31 .

${ }^{563}$ Ibidem., p. 32. 
surgidos após sua apresentação, os membros da Câmara acharam prudente revisar todo projeto, mesmo aqueles dispositivos que não tinham sofrido qualquer alteração. Assim, pela Resolução CN 01/2000, de 31 de janeiro de 2000, que mudou o Regimento Geral do Congresso Nacional, ficou decidido que antes da discussão final na Casa que enviaria o projeto à sanção presidencial, ele seria revisto, para adequação às novas mudanças constitucionais e legais. ${ }^{564}$

Assim, o projeto passou por uma nova análise realizada pelas Comissões de Constituição e Justiça das duas Casas. Mais uma vez, foram ouvidas as manifestações de juristas e entidades de classe. Após a aprovação do projeto e a sanção do Presidente da República, Fernando Henrique Cardoso, foi finalmente promulgada a lei n. 10. 406 de 10 de janeiro de 2002, o Novo Código Civil, entrando em vigor um ano mais tarde, em 11 de janeiro de $2003 .^{565}$

\subsection{Código Civil de 2002}

Depois de mais de meio século de tentativas de atualização e substituição do Código Civil de 1916, o ordenamento pátrio recebeu a lei 10. 406 de 2002. A nova legislação trouxe mudanças significativas à disciplina da transmissão da propriedade pelo registro do título e as seguranças que devem envolvê-la.

Antes de tratar do conteúdo dos dispositivos propriamente dito, importante analisar a organização estrutural da matéria, já que a forma como vem disciplinada pode ou não facilitar sua aplicação e interpretação.

Como foi visto no item 3.3, as matérias relativas à transmissão da propriedade imóvel pelo registro do título e ao registro de imóveis vinham reguladas no Código Civil de 1916 em Títulos distintos; o primeiro, naquele referente à propriedade e o segundo no Título que dispunha sobre direitos reais sobre coisas alheias, o que levava o intérprete à falsa

\footnotetext{
${ }^{564}$ Reale, Miguel. In: Reale, Miguel ; Costa, Judith Martins (coord.). História do Novo Código Civil. São Paulo: Tribunais, 2005. p. 260.

${ }^{565}$ Reale, Miguel. In: Reale, Miguel ; Costa, Judith Martins (coord.). História do Novo Código Civil. São Paulo: Tribunais, 2005. p. 260.
} 
impressão de que o registro de imóveis dizia respeito unicamente à hipoteca. Esse entendimento mostrava-se equivocado, na medida em que o próprio código enumerava no artigo 856 os atos sobre os quais o registro de imóveis recaía, tratando muito mais do que daquele direito de garantia. ${ }^{566}$

Diante dessa má organização estrutural da matéria, não foi difícil para o Novo Código Civil apresentar avanços nesse sentido. A lei de 2002 acertou ao inserir os dispositivos referentes à transferência da propriedade imóvel pelo registro do título no Título III (da propriedade), Capítulo II (da aquisição da propriedade imóvel), Seção II (da aquisição pela transcrição do título) e a não mais prever uma seção destinada ao registro de imóveis, que passou a ser disciplinado unicamente pela legislação específica de Registros Públicos.

No entanto, apesar de não ter qualquer seção especialmente destinada ao registro de imóveis, o Novo Código Civil acabou interferindo na legislação específica ao tratar sobre matérias a ela pertinentes. A interferência acabou incluindo desnecessariamente dispositivos na nova legislação civil que em nada contribuíram para o aprimoramento do sistema registral imobiliário, uma vez que simplesmente repetiu regras que deveriam ficar restritas a Lei de Registros Públicos. Não há nenhum problema em o Código prever que o título de transferência da propriedade imóvel seja registrado, porém não há necessidade de que ele disponha sobre a possibilidade de retificação ou ainda sobre o momento em que o registro se torna eficaz. Estas matérias, além de já serem previstas pela Lei de Registros Públicos de 1973 (artigos 212 a 214,216 e artigos 182, 183, 186, 205, respectivamente) são essencialmente registrarias. ${ }^{567}$

Dessa forma, sob o aspecto da sistemática, apesar de ter havido avanços no relativo ao Código de 1916, o Código de 2002 ainda deixou a desejar, já que previu matérias de natureza meramente registrária, ou melhor, repetiu previsões da Lei de Registros Públicos de 1973, sem que houvesse qualquer motivo ou necessidade para isso.

${ }^{566}$ CARVAlHo, Afrânio de. Registro de Imóveis. $3^{\text {a }}$ ed., Rio de Janeiro: Forense, 1982. p. 21.

${ }^{567}$ Destaca-se que a maior interferência na regulamentação registraria ocorreu em outros pontos do Código Civil de 2002, como por exemplo, no relativo a hipoteca. Esta lei teve a infelicidade de destinar uma seção unicamente ao registro da hipoteca na qual praticamente reproduziu a Lei de Registros Públicos de 1973, dispondo inclusive sobre direito formal registrário (como competência dos oficiais no art. 1492, procedimento de inscrição da hipoteca no art. 1.495, procedimento de dúvida registraria no art. 1496). Para se referir ao registro de hipoteca bastaria dispor unicamente que "a hipoteca $\mathrm{X}$ só terá validade se registrada" ou "a hipoteca $\mathrm{Y}$ e $\mathrm{Z}$ só serão oponíveis a terceiros se registradas", já que são pontos não tratados pela lei de Registros Públicos. A mera reprodução da lei ou a disposição de direito formal e material registrário não parece de grande valia. 
Outro ponto a se frisar é quanto ao uso do termo "registro". Como já foi visto no item 3.3, o Código Civil de 1916 fazia grande confusão entre os termos transcrição e inscrição, não utilizando essas palavras de acordo com as suas definições. O Novo Código Civil terminou com qualquer imprecisão terminológica a este respeito, ao utilizar unicamente a palavra "registro", 568

Quanto ao conteúdo propriamente dito, o Novo Código Civil não tratou sobre o Registro Torrens ${ }^{569}$, dedicando-se unicamente ao sistema registrário comum. No relativo a esse regime, reproduziu a maioria dos dispositivos do antigo e inovou apenas na matéria que por tantos anos havia gerado controvérsias na doutrina, ou seja, a proteção ao terceiro adquirente de boa-fé. Como já visto, o Anteprojeto de Código Civil de 1972 consagrava a segurança do direito de propriedade ao permitir o cancelamento do registro, mesmo nos casos em que o adquirente estivesse de boa-fé. $\mathrm{O}$ artigo do projeto foi aprovado com apenas uma pequena alteração; substituiu-se a palavra "transcrição" por registro, como ocorreu com outros dispositivos do Código, a fim de que se mantivesse a coerência com a Lei de Registros Públicos de 1973. A redação do artigo então ficou:

"Art. 1.247. Se o teor do registro não exprimir a verdade, poderá o interessado reclamar que se retifique ou anule.

Parágrafo único. Cancelado o registro, poderá o proprietário reivindicar o imóvel, independentemente da boa-fé ou do título do terceiro adquirente."

Com esta previsão, não havia mais como defender que o registro tinha presunção absoluta de domínio em relação ao adquirente de boa-fé a título oneroso. A presunção do registro era relativa, admitia retificação ou anulação, mesmo que estes atos prejudicassem terceiro que confiando nas informações do assento registral havia adquirido o bem imóvel. Assim, diante de vícios substanciais, como no caso de compra a non domino, negócio jurídico nulo ou anulável, ou formais, por ofensa ao procedimento registrario, o assento poderia ser cancelado, prejudicando aquele que ignorava o obstáculo que impedia a aquisição do imóvel.

\footnotetext{
${ }^{568}$ Ressalta-se que a substituição das palavras "transcrição e inscrição" por "registro" ocorreu momentos antes da publicação do novo Código, ou seja, no projeto original a imprecisão terminológica histórica se mantinha, apesar da Lei de Registros Públicos a ter superado. Graças aos juristas que revisaram o Novo Código Civil, não houve retrocessos, uma vez que a Lei de Registros Públicos foi acompanhada e, conseqüentemente, a imprecisão abolida.

${ }^{569}$ Atualmente, o Registro Torrens é disciplinado pela Lei de Registros Públicos de 1973 (art. 277 a 288).
} 
No entanto, a fim de que o terceiro adquirente não ficasse totalmente desamparado pelo ordenamento, ele poderia utilizar o instituto jurídico do usucapião para a aquisição do imóvel desde que cumprisse o requisito do prazo. O Novo Código Civil facilitou a aquisição do bem pelo terceiro adquirente de boa-fé a título oneroso nos casos de cancelamento do registro, prevendo dispositivo específico para essa situação. O artigo dispõe:

“Art. 1.242. Adquire também a propriedade do imóvel aquele que, contínua e incontestadamente, com justo título e boa-fé, o possuir por dez anos.

Parágrafo único. Será de cinco anos o prazo previsto neste artigo se o imóvel houver sido adquirido, onerosamente, com base no registro constante do respectivo cartório, cancelada posteriormente, desde que os possuidores nele tiverem estabelecido a sua moradia, ou realizado investimentos de interesse social e econômico."

Perceba-se como se trata de um usucapião diferenciado, uma vez que não tem a função ordinária de modo de aquisição originária de propriedade, mas sim visa unicamente sanar os vícios originais de um negócio jurídico de aquisição derivada já existente. ${ }^{570}$

Em 2004, a lei n. 10.931 de 2 de agosto reforçou o entendimento ao incluir no artigo 214 da Lei de Registros Públicos o seguinte parágrafo:

“ $§ 5^{\circ}$. A nulidade não será decretada se atingir terceiro de boa-fé que já tiver preenchido as condições de usucapião."

Dessa maneira, sem que o ordenamento previsse a presunção absoluta de domínio do registro consagrando a segurança do comércio, ele não deixou totalmente desprotegido aquele que, confiando nas informações contidas no livro registral, adquiriu um bem imóvel a título oneroso. Ao impedir a nulidade do registro, quando presentes os requisitos do usucapião, o legislador garantiu maior segurança às transações comerciais e, conseqüentemente, ao crédito. E isso significou possibilidade de maiores investimentos, redução das taxas de juros e dos empréstimos usurários.

Interessante perceber como a tão sonhada coexistência das seguranças do crédito, do direito de propriedade e do comércio acabou sendo alcançada por via diferente daquela

${ }^{570}$ Peluzo, César (Coord.). Código Civil Comentado: doutrina e jurisprudência, 2a ed., Barueri-SP: Manole, 2008. p. 1.180. 
imaginada pelos autores do final do século XIX e início do século XX. Estes entendiam que a existência concomitante das três acepções da segurança jurídica dependeria da aplicação, pelo Brasil, do sistema cadastral germânico o que acabou não ocorrendo apesar da intensa luta travada por diversos juristas ao longo dos anos. O sistema registral brasileiro acabou adotando a matrícula dos imóveis que, apesar de trazer maior segurança aos assentos registrais, não foi suficiente para eliminar as discordâncias entre a situação fática e jurídica do imóvel, principalmente pelo fato de muitos imóveis ainda não a possuírem. O problema parecia sem solução, até que o legislador, de outra maneira, acabou por atingir o resultado esperado ao conciliar as seguranças.

Assim, a partir do momento em que o adquirente de boa-fé a título oneroso preenche todas as condições do usucapião, a presunção de seu domínio torna-se absoluta, não havendo possibilidade de cancelamento do registro por nulidade do título anterior. Em outras palavras, durante o prazo de cinco anos, o ordenamento garante a segurança do direito de propriedade; passado esse tempo e não tendo o real proprietário reivindicado o bem, nada mais justo que se priorize a segurança do comércio e, conseqüentemente, a segurança do crédito.

No entanto, não se pode esquecer que em alguns casos, para se obter a segurança do comércio serão necessários muito mais que cinco anos. Isso porque, de acordo com o artigo 1.244 do Novo Código Civil, as causas que obstam, suspendem e interrompem a prescrição extintiva também devem ser aplicados para a prescrição aquisitiva (art. 197 a 200 do Código Civil de 2002) o que prolongará o tempo em que prepondera a segurança do direito de propriedade.

Mesmo com a possibilidade do prazo para a consolidação do vício superar os cinco anos, não há como negar que, afastando-se da linha histórica que parecia aproximar cada vez mais o sistema registrário brasileiro do germânico, ao procurar garantir as três seguranças de maneira concomitantemente por meio de um cadastro imobiliário, o legislador brasileiro inovou positivamente, ao conciliar as seguranças por meio do usucapião, priorizando uma e outra em momentos distintos. 


\section{CONCLUSÃO}

A normatização da transferência da propriedade imóvel inter vivos no Brasil decorreu da necessidade, em momentos distintos, de garantir-se a segurança jurídica do crédito, do direito de propriedade e do comércio.

Ao perseguir a segurança do crédito, a intenção do legislador era utilizar o bem imóvel como garantia de empréstimos, o que permitiria a negociação de maiores quantias a menores taxas, aumentando a quantidade de capital circulante. 
$\mathrm{Na}$ segurança do direito de propriedade, o objetivo era garantir ao senhor do domínio, que ele não perderia a titularidade sobre o bem imóvel, sem que fosse sua vontade ou sem seu conhecimento.

Na segurança do comércio, o intuito era tornar seguras as relações comerciais de aquisição de bens imóveis. Permitir que o adquirente de boa-fé pudesse confiar nas informações obtidas por meio das certidões emitidas pela Serventia de Registro Imobiliário, não perdendo a titularidade sobre o bem quando averiguado que o assento registral não exprimia a verdade.

Um sistema imobiliário que tornasse seguro o comércio de bens imóveis, com maior razão forneceria certeza ao crédito imobiliário, já que os dados presentes no assento registral seriam mantidos independentemente da descoberta de fraudes nas transações passadas.

A dificuldade maior sempre foi conciliar a segurança do comércio e, conseqüentemente, do crédito, com a segurança do direito de propriedade. A convivência no ordenamento jurídico de duas seguranças que eram em sua essência contrárias, dependia de um sistema de registro imobiliário fiel às características físicas e jurídicas do bem.

Verificando que as seguranças almejadas somente seriam obtidas com a definição física do imóvel, a qualificação de seu titular e a indicação dos ônus reais, o legislador passou a construir um sistema de registro imobiliário, o que fez surgir no ordenamento figuras jurídicas como a transcrição, inscrição, princípio da especialidade, da continuidade entre outros.

Como a transmissão da propriedade imóvel inter vivos consiste em um ato complexo, que envolve o título e o registro, ao disciplinar o sistema registral imobiliário, o legislador também aperfeiçoou esse modo de aquisição derivada.

O desenvolvimento do instituto da transmissão no Brasil foi impressionante. Apesar das mudanças terem sido gradativas e exigido o decurso de tempo significativo, o resultado foi animador, destacando-se a criação da matrícula e a iniciativa do legislador de 
facilitar a aquisição do bem pelo usucapião àquele que de boa-fé e a título oneroso obtivesse imóvel de quem apesar de inscrito não era dono.

Esse tipo de usucapião foi a solução encontrada pelo legislador brasileiro para priorizar não só a segurança do direito de propriedade, como também a do comércio. Em princípio, a intenção era que a matrícula proporcionasse a formação de um cadastro real. Assim, ao trazer todos os dados sobre o imóvel, permitiria em um futuro próximo a convivência das seguranças. Contudo, como anos passaram-se e muitos imóveis ainda não possuíam matrícula, previu-se uma medida conciliatória. A partir de então, passou-se a preferir uma ou outra segurança em momentos distintos. Primeiramente, o foco ocorre na segurança do direito de propriedade; depois, transcorrido o prazo do usucapião, destaca-se o direito do comércio e, conseqüentemente, o do crédito.

Tomadas todas as providências legais para garantir um sistema seguro de transmissão da propriedade imóvel, hoje, o desafio é outro.

A vastidão do território nacional, o desconhecimento de parte da população sobre o modo de aquisição do bem imóvel e os altos custos de transação (principalmente com tributos) são os novos obstáculos a serem transpostos.

Afinal, não há que se falar em segurança do crédito, do direito de propriedade e do comércio, se grande parte dos imóveis ainda são transmitidos e onerados à margem do sistema registrário. As seguranças apenas existirão de fato, quando ultrapassarem o texto legislativo e atingirem a realidade nacional, incluindo no sistema todas as propriedades imóveis, ou melhor, todas as classes sociais. 


\section{REFERÊNCIAS}

ALMEIDA, Francisco de Paula Lacerda de. Direito das Cousas. Rio de Janeiro: Jacintho Ribeiro dos Santos, 1908.

ALVES, João Luiz. Código Civil da Republica dos Estados Unidos do Brasil annotado. $2^{\mathrm{a}} \mathrm{ed}$., São Paulo: Saraiva \& Cia, 1935. vol.1 ${ }^{\circ}$. 
ARARIPE, Tristão de Alencar. Código Civil brazileiro ou Leis Civis do Brazil. Rio de Janeiro: Laemmert \& C., 1885.

ASSIS, Jacy de. Do Registro Torrens. Revista dos Tribunais, São Paulo, v. 371, ano 55, set. 1966.

ASSOCIAÇÂO BRASILEIRA DE NORMAS TÈCNICAS. NBR 10520/2002: informação e documentação - apresentação de citações em documentos. Rio de Janeiro, 2002.

. NBR 6023: informação e documentação - referências - elaboração. Rio de Janeiro, 2002.

- NBR 14724/2005:informação e documentação - trabalhos acadêmicos apresentação. Rio de Janeiro, 2005.

ÁVILA, Humberto (Org.). Fundamentos do Estado de Direito. Estudos em homenagem ao professor Almiro do Couto e Silva. São Paulo: Malheiros, 2005.

AZEVEDO, Luiz Carlos de. Introdução à história do direito. São Paulo: Revista dos Tribunais, São Paulo, 2005.

AZEVEDO, Philadelpho. Registros Públicos. Lei $n .4 .827$ de 7 de fevereiro de 1924 (commentario e desenvolvimento). Rio de Janeiro: Litho- Tupo Fluminense (S.A), 1924.

Registros Públicos. Archivo Judiciário/Jornal do Commercio. Rio de Janeiro: Rodrigues e CIA, 1940. vol.LII.

. Registro de Imóveis (Valor da Transcrição). Rio de Janeiro: Jacintho, 1942. 
BATALHA, Wilson de Souza Campos. Comentários à Lei de Registros Públicos. $4^{\mathrm{a}}$ ed., Rio de Janeiro: Forense, 1997. vol.I.

BEVILAQUA, Clóvis. Em Defeza do projecto de Código Civil Brazileiro. Rio de Janeiro: Francisco Alves, 1906.

. Direito das Coisas, vol.I. In: Coleção da História do Direito Brasileiro. Direito Civil. Obra fac-similar. Brasília: Senado Federal, Conselho Editorial, 2003.

BORGES, João Afonso, O Registro Torrens no Direito Brasileiro. São Paulo: Saraiva, 1960.

BRASIL. Anais da Câmara dos Deputados, vol.12. Sessões de 24 de agosto a 4 de setembro de 1972. Brasília: Oficinas do Serviço Gráfico da fundação IBGE, [s.d.].

Annaes do Parlamento Brazileiro. Camara dos Srs. Deputados. Sessão de 1864. Tomo Quarto, 1864.

. Annaes do Senado do Império do Brasil, $1^{\mathrm{a}}$ sessão de 1864, vol. III. Rio de Janeiro: Typ. do Correio Mercantil de M. Barreto, Mendes Campos, e Comp.,1864.

. Annaes do Senado do Império do Brasil, $2^{\mathrm{a}}$ sessão de 1864, vol I. Rio de Janeiro: Typ. do Correio do Comercio Mercantil de M. Barreto, Mendes Campos, e Comp., 1864.

Annaes do Parlamento Brazileiro. Câmara dos Srs. Deputados. Sessão de 1855. Tomo Segundo. Rio de Janeiro: Typographia de Hyppolito José Pinto \& C., 1875.

. Annaes do Parlamento Brazileiro. Câmara dos Srs. Deputados. Sessão de 1856. Tomo Quarto. Rio de Janeiro: Typographia de - Hyppolito José Pinto \& C. ${ }^{\mathrm{a}}, 1875$. 
.Annaes do Parlamento Brazileiro. Câmara dos Srs. Deputados. Sessão de 1854. Tomo Terceiro. Rio de Janeiro: Typographia de - Hyppolito José Pinto \& C. a , 1876.

.Annaes do Parlamento Brazileiro. Câmara dos Srs. Deputados. Segunda sessão de 1850. Tomo Quarto. Rio de Janeiro. Typographia de H.J. Pinto, 1880.

Annaes do Parlamento Brazileiro. Camara dos Srs. Deputados. Primeira Sessão de 1843. Tomo Segundo. Rio de Janeiro: Typographia da Viúva Pinto \& Filho, 1882.

Anteprojeto de Código Civil. Apresentado ao Exmo. Sr. João Mangabeira, Ministro da Justiça e Negócios Interiores, em 31 de março de 1963, pelo prof. Orlando Gomes. Rio de Janeiro: Departamento de Imprensa Nacional, 1963.

. Anteprojeto de Código Civil. Brasília. Departamento de Imprensa Nacional, 1972.

. Câmara dos Deputados. Projecto do Código Civil Brazileiro do Dr. Joaquim Felício dos Santos. Organizado pelo Conselheiro José Thomaz Nabuco de Araújo. Rio de Janeiro: Typographia Nacional, 1882.

Código Civil: anteprojetos, vol.1, Brasília: Senado Federal, Subsecretaria de Edições Técnicas, 1989.

. Código Civil: anteprojetos, vol.2, Brasília: Senado Federal, Subsecretaria de Edições Técnicas, 1989.

. Código Civil: anteprojetos, vol.3, Brasília: Senado Federal, Subsecretaria de Edições Técnicas, 1989. 
Técnicas, 1989.

Código Civil: anteprojetos, vol4, Brasília: Senado Federal, Subsecretaria de Edições

. Decreto n.482 - de 14 de novembro de 1846. Estabelece o Regulamento para o Registro geral das hypothecas. Disponível em: $<$ http://www6.senado.gov.br/legislacao/ListaPublicacoes.action?id=81506 $>$. Acesso em: 30 abr. 2008.

Setemb

Decreto n.1.318 - de 30 de janeiro de 1854. Manda executar a Lei $N^{o} 601$ de 18 de

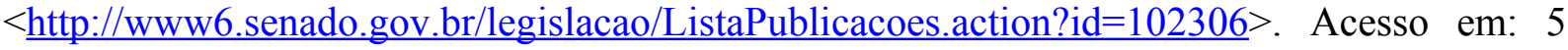
maio 2008.

. Decreto n.3453 - de 26 de abril de 1865. Manda observar o Regulamento para execução da Lei $n^{\circ} 1237$ de 24 de Setembro de 1854, que reformou a legislação hypothecaria. Dispoanível em: < $\underline{\text { http://www6.senado.gov.br/legislacao/ListaPublicacoes.action?id=75814> }}$. Acesso em: 1 maio 2008.

execuções

Decreto n. 3272 - de 5 de outubro de 1885. Altera diversas disposições referentes ás

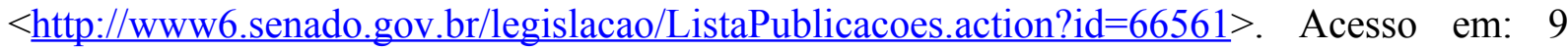
jun. 2008.

. Decreto n. 169 A - de 19 de janeiro de 1890. Substitue as leis n. 1237 de 24 de setembro de 1864 e $n .3272$ de 5 de outubro de 1885. Disponível em:

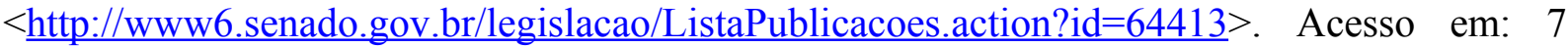
maio 2008.

. Decreto n. 370 - de 2 de maio de 1890 . Manda observar o regulamento para execução do decreto $n$. 169 A de 19 de janeiro de 1890, que substituiu as leis n. 1237 de 24 de setembro de 1864 e n. 3272 de 5 de outubro de 1885, e do decreto $n .165$ A de 17 de janeiro de 1890, sobre operações de credito movel. Disponível em: $<$ http://www6.senado.gov.br/legislacao/ListaPublicacoes.action?id=64404 $>$. Acesso em: 20 maio 2008. 
$\begin{array}{ccccc}\text {. Decreto n. } 451 \mathrm{~B}-\text { de } & 31 \text { de maio de } & \text { 1890. Estabelece o registro e transmissão de } \\ \text { immovei } & \text { pelo } & \text { systema } & \text { Torrens. } & \text { Disponível }\end{array}$ $<$ http://www6.senado.gov.br/legislacao/ListaPublicacoes.action?id=66177 $>$. Acesso em: 2 jun. 2008.

. Decreto n.. 955 A - de 5 de novembro de 1890. Promulga o regulamento para execução do decreto $n .451 \mathrm{~B}$, de 31 de maio do corrente anno, que estabeleceu o registro e transmissão de immoveis pelo systema Torrens. Capital Federal. Disponível em: $<$ http://www6.senado.gov.br/legislacao/ListaPublicacoes.action?id=65182>. Acesso em: 2 jun. 2008.

. Lei n.317, de 21 de outubro de 1843. Fixando a Despeza e orçando a Receita para os

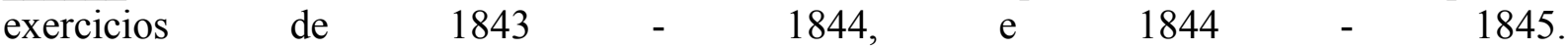
< http://www.planalto.gov.br/ccivil 03/Leis/LIM/LIM317.htm>. Acesso em: 28 abr. 2008.

. Lei n.601, de 18 de setembro de 1850. Dispõe sobre as terras devolutas no Império, e acerca das que são possuídas por titulo de sesmaria sem preenchimento das condições legais. bem como por simples titulo de posse mansa e pacifica; e determina que, medidas e demarcadas as primeiras, sejam elas cedidas a titulo oneroso, assim para empresas particulares, como para o estabelecimento de colonias de nacionaes e de extrangeiros, autorizado o Governo a promover a colonisação extrangeira na forma que se declara. $<\underline{\mathrm{https}}$ :// www.planalto.gov.br/ccivil 03/leis/lim/lim601.htm $>$. Acesso em: 2 maio 2008.

. Lei n. 1.237 de 24 de setembro de 1864. Dispõe sobre a "Reforma a Legislação Hypothecaria, e estabelece as bases da sociedade de credito real". Disponível em:

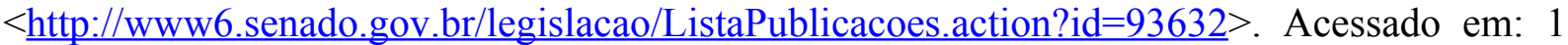
maio 2008.

- Novo Código Civil. Exposição de Motivos e texto sancionado. Brasília: Senado Federal. Secretaria Especial de Editoração e Publicações, 2002.

. Projecto do Codigo Civil Brazileiro. Trabalhos da Comissão Especial da Camara dos Deputados, vol. VI. Rio de Janeiro: Imprensa Nacional, 1902. 
Projecto do Codigo Civil Brazileiro. Trabalhos da Commissão Especial do Senado, vol. III. Pareceres e emendas enviados á Commissão. Rio de Janeiro: Imprensa Nacional, 1904.

BUENO, Fernando Euler. Effeitos da transcripção no regime do Código Civil Brasileiro. São Paulo: Revista dos Tribunais, 1941.

CALDEIRA, Jorge. Mauá: empresário do Império. São Paulo: Companhia das Letras, 1995.

CAMPOS, Antônio Macedo de. Comentários à Lei de Registros Públicos. $3^{\circ}$ vol., Bauru: Jalovi Ltda, 1977.

CANOTILHO, José Joaquim Gomes. Direito Constitucional. $6^{\mathrm{a}}$ ed., Coimbra: Almedina, 1993.

Direito Constitucional e Teoria da Constituição. Coimbra: Almedina, 1998.

CARNEIRO, Andrea Flávia Tenório. Cadastro Imobiliário e Registro Imobiliário. Porto Alegre: Sérgio Antônio Fabris, 2003.

CARVALHO, Afrânio. Registro de Imóveis: última versão (Lei n. 6.015, de 1973). Revista dos Tribunais, São Paulo, v. 459, ano 63, 1974.

. Registro de Imóveis (Lei n. 6.015, de 31.12.1973, com as alterações da Lei n. 6.216, de 30.6.1975). Revista dos Tribunais, São Paulo, v. 481, ano 64, 1975.

. Registro de Imóveis. $3^{\mathrm{a}}$ ed., Rio de Janeiro: Forense, 1982. 
CARVALHO, José Murilo de. A formação das almas: o imaginário da República no Brasil. São Paulo: Companhia das Letras, 1990.

- A construção da ordem: a elite política imperial. Teatro de Sombras: a política imperial. $3^{\text {a }}$ ed., Rio de Janeiro: Civilização Brasileira, 2003.

. Perfis Brasileiros: D. Pedro II. São Paulo: Companhia das Letras, 2007.

CENEVIVA, Walter (Org.). A lei de Registros Públicos e o Direito Imobiliário. São Paulo: Associação dos Advogados de São Paulo, 1976.

. Apontamentos sobre o novo direito imobiliário brasileiro. 1977. 92f. Dissertação apresentada como exigência para obtenção do grau de Mestre em direito à Comissão Julgadora da Pontifícia Universidade Católica de São Paulo - Área do Direito Civil.

CESAR, José Augusto. Ensaio sobre os actos jurídicos. Campinas: Typ da Casa Genoud, 1913.

- Sobre o Registro de Imóveis. Revista da Faculdade de Direito de São Paulo, São Paulo, n. 31, set. 1935.

COÊLHO RODRIGUES, Antônio. Projecto do Codigo Civil Brazileiro. Rio de Janeiro: Imprensa Nacional, 1893.

COSTA, Emília Viotti da. Da Monarquia à República: momentos decisivos. $8^{\mathrm{a}}$ ed., São Paulo: Fundação UNESP, 2007. 
COSTA PORTO, José da. O sistema sesmarial no Brasil. Brasília: Universidade de Brasília, [s.d.].

DAVATZ, Thomas. Memórias de um colono no Brasil. São Paulo: Martins, 1972.

DIP, Ricardo Henry Marques (Org). Registros Públicos e segurança jurídica. Porto Alegre: Sergio Antonio Fabris, 1998.

. Sobre a crise contemporânea da segurança jurídica. Revista de Direito Imobiliário, São Paulo, n. 54, ano 26, 2003.

ERPEN, Décio Antônio Paiva; LAMANA, João Pedro. Panorama histórico do registro de imóveis no Brasil. Revista de Direito Imobiliário, São Paulo, n. 43, ano 21, 1998.

ESPINOLA, Eduardo e ESPINOLA FILHO, Eduardo. Tratado de Direito Civil Brasileiro. Rio de Janeiro: Freitas Bastos, 1939. vol.II

FAORO, Raymundo. Os Donos do Poder; formação do patronato político brasileiro. Porto Alegre: Globo, 1958.

FAUSTO, Boris. História do Brasil. $6^{\mathrm{a}}$ ed., São Paulo: Universidade de São Paulo: Fundação para o desenvolvimento da Educação, 1999.

FELÍCIO DOS SANTOS, Joaquim. Projecto do Codigo Civil Brazileiro e Commentario. Rio de Janeiro: Laemmert \& C, 1887. Tomo V

FONSECA, Arnoldo Medeiros. Effeitos da transcripção. Revista dos Tribunais, São Paulo, v. 107, ano 26, maio de 1937. 
- O registro immobiliário e sua força probante em face do Código Civil. Archivo/Jornal do Commercio. Rio de Janeiro: Rodrigues \& C., 1937. vol.XLII.

FRANÇA, Rubens Limongi. Legislação dos Registros Públicos. São Paulo: Revista dos Tribunais, 1976.

FURTADO, Celso. Formação Econômica do Brasil. 23ª ed., São Paulo: Nacional, 1989.

GARCIA, Lysippo. O Registro de Imóveis: a transcrição. Rio de Janeiro: Francisco Alves, 1922. vol.1.

. O Registro de Imóvei: a inscrição. Rio de Janeiro: Francisco Alves, 1927. vol.2.

GILISSEN, Jonh. Introdução Histórica ao Direito. $3^{\mathrm{a}}$ ed., Lisboa: Calouste Gulbenkian, 2001.

GOMES, Orlando. Memória Justificativa de Reforma do Código Civil. Rio de Janeiro: Departamento de Imprensa Nacional, 1963.

. A Reforma do Código Civil. Salvador: Publicações da Universidade da Bahia, 1965.

. A introdução do princípio da continuidade do registro. Revista de Direito Imobiliário, São Paulo, n.1, 1978.

. Raízes históricas e sociológicas do Código Civil Brasileiro. São Paulo: Martins Fontes, 2003. 
GUERREIRO, José Augusto G. Mouteira, O Registro imobiliário: Necessário instrumento do progresso econômico-social. Revista de Direito Imobiliário, São Paulo, n. 45, ano 21, 1998.

GUIMARÃES, Otávio Moreira. A Boa-Fé no Direito Civil Brasileiro. São Paulo: Emprêsa Gráfica da "Revista dos Tribunais", 1938.

. In: Comentário a acórdão do Tribunal de Apelação de S. Paulo. Revista dos Tribunais, v. CXXXIII, n. 496, ano XXX, set 1941.

INSTITUTO DE REGISTRO IMOBILIÁRIO BRASILEIRO: Aviso de 8 de Maio de 1854. Dá Regulamento provisorio para mediação e demarcação das terras devolutas e particulares, em execucção do $\S 2 .^{\circ}$ do Art. 3. ${ }^{\circ}$ do Decreto n. 1.318 de 30 de Janeiro do corrente anno. <http://www.irib.org.br/leis_imperio/aviso08051854.asp. $>$. Acesso em: 30 abr. 2008.

JACOB, François et al. Code Civil. 101ª ed., Paris: Dalloz, 2002.

JARDIM, Mônica. O sistema registral germânico. Revista de Direito Imobiliário, São Paulo, n. 59, ano $28,2005$.

JUNQUEIRA DE AZEVEDO, Antônio. O direito pós-moderno e a codificação. Revista de Direito do Consumidor,São Paulo, n. 33, ano 9, jan-mar 2000.

LINS, Jair. Pareceres e Razões. Revista Forense, Rio de Janeiro, n. 55, [s.d.], 1930.

LOPEZ, Adriana e MOTA, Carlos Guilherme. História do Brasil: uma interpretação. São Paulo: Senac São Paulo, 2008. 
KONNO, Alyne Yumi. Registro de Imóveis, teoria e prática. São Paulo: Memória Jurídica, 2007.

LACERDA, Paulo de. Codigo Civil Brasileiro. Rio de Janeiro: Jacintho Ribeiro dos Santos, 1916.

LIMA, Ruy Cirne. Pequena História Territorial do Brasil: Sesmarias e Terras Devolutas. $2^{a}$ ed., Porto Alegre: Sulina, 1954.

LIRA, Ricardo Pereira. Campo e cidade no ordenamento jurídico brasileiro. Rio de Janeiro: Riex, 1991.

LISTA DE IMÓVEIS CERTIFICADOS. <http://200.252.80.5/credencia/Lista2.asp>. Acesso em: 19 jan. 2009.

LOPES, Américo, LOPES, Cícero. Commentarios, Notas e Formulários sobre o Registro Torrens. Rio de Janeiro: Jacintho Ribeiro dos Santos, 1925.

LOPES, José Reinaldo de Lima. O direito na história. São Paulo: Max Limonad, 2000.

LOUREIRO, Waldemar. Registro da Propriedade Imóvel. 6ed., Rio de Janeiro: Revista Forense, 1968. vol.I.

MEIRA, Francisco de. Pareceres. Revista Forense, Rio de Janeiro, v. 78, ano 36, 1939.

MELO JR., Regnoberto Marques de. Lei de Registros Públicos Comentada. Rio de Janeiro: Freitas Bastos, 2003. 
MENDES DE ALMEIDA, Cândido. Código Philippino. Rio de Janeiro: Typographia do Instituto Philomathico, 1870. vol.3. vol.4.

. Código Philippino. Rio de Janeiro: Typographia do Instituto Philomathico, 1870.

MILTON, Aristides A. A Constituição do Brazil. Noticia histórica, texto e commentario. $2^{\mathrm{a}}$ ed., Rio de Janeiro: Imprensa Nacional, 1898.

MONTES, Angel Cristóbal. Direito Imobiliário Registral. Tradução de Francisco Tost. Porto Alegre: Sergio Antonio Fabris, 2005.

OLIVEIRA, Altino Antoine de. Registro de Immoveis. Comprehensão, execução e melhoramentos. [s.n.], 1938.

OLIVEIRA, A. Gonçalves de. Valor probante do registro de immoveis. Archivo Judiciário/ Jornal do Commercio. Rio de Janeiro: Rodrigues \& CIA, 1939. vol. LII.

PAIVA, João Pedro Lamana. A sistemática do Registro de Imóveis. $3^{\mathrm{a}} \mathrm{ed}$., Porto Alegre: Síntese, 1980.

PELUZO, César (Coord.). Código Civil Comentado: doutrina e jurisprudência. 2a ed., Barueri-SP: Manole, 2008.

PERDIGÃO MALHEIROS, Augustinho Marques. Repertório ou Índice Alphabetico da Reforma Hypothecaria e sobre sociedades de credito real. Rio de Janeiro: Typographia Nacional, 1865.

PEREIRA, Lafayette Rodrigues. Direito das Cousas. Rio de Janeiro: Jacintho Ribeiro dos Santos, [s.d.]. vol.I. 
PICANÇO, Melchiades. O direito das cousas (em face do Código Civil). Rio de Janeiro: Comp. Nac. Artes Graphicas, 1926. . Dos registros públicos. Rio de Janeiro: A.Coelho Branco Fº 1940.

PIMENTA BUENO, José Antônio. Direito Público Brasileiro e análise da Constituição do Império. Rio de Janeiro: José Bushatsky, 1958.

PINHEIRO, Paulo Sérgio. Classes médias urbanas: formação, natureza, intervenção na vida política. In: PINHEIRO, Paulo Sérgio et al. O Brasil Republicano: sociedade e instituições (1889-1930). 8a ed., Rio de Janeiro: Betrand Brasil, 2006. vol.9.

PIRES NETO, Ari Álvares. Georreferenciamento e retificação extrajudicial de imóveis urbanos e rurais. Revista de Direito Imobiliário, São Paulo, n. 58, ano 28, jan e jun 2006.

PONTES DE MIRANDA. Fontes e evolução do Direito Civil Brasileiro. Rio de Janeiro: Pimenta de Mello \& C., 1928.

. Tratado de Direito Predial. Rio de Janeiro: José Konfino, 1947. vol.I.

PONTES, Valmir. Registro de imóveis: comentários aos arts. 167 a 288 da Lei n. 6.015 de 31 de dezembro de 1973. São Paulo: Saraiva, 1982.

POVEDA VELASCO, Ignácio Maria. Ordenações do Reino de Portugal. Revista da Faculdade de Direito da Universidade de São Paulo, v.89, 1994. 
. Os esponsais no direito luso-brasileiro. São Paulo: Quartier Latin, 2003.

. Três vultos da cultura jurídica brasileira: Augusto Teixeira de Freitas, Tobias Barreto de Menezes e Clóvis Bevilaqua. In: BITTAR, Eduardo C. B. (Org). História do Direito Brasileiro. Leituras da Ordem Jurídica Nacional. São Paulo: Atlas, 2003.

PRADO, Francisco Bertino de Almeida. Transmissão da propriedade imóvel. São Paulo: Saraiva \& Comp., 1934.

QUEIROZ, Maria Isaura Pereira de. O coronelismo numa interpretação sociológica. FAUSTO, Boris (direção). O Brasil Republicano: estrutura de poder e economia (1889-1930). Rio de Janeiro: Bertrand Brasil, 2006/vol.8.

REALE, Miguel e COSTA, Judith Martins (Coord.). História do Novo Código Civil. São Paulo: Editora dos Tribunais, 2005.

. Em defesa do anteprojeto do Código Civil. O Estado de São Paulo, São Paulo, dias 30 e 31 dez. 1972 e dias 5, 7 e 9 jan. 1973.

RICHTER, Luiz Ergon. A trajetória do título no Registro de Imóveis: considerações gerais. Revista de Direito Imobiliário, São Paulo, n 56, ano 27, 2004.

RODRIGUES, Sílvio. Registro de Imóveis. In: FRANÇA, R. Limongi (Coord.). Enciclopédia Saraiva do Direito. São Paulo: Saraiva, 1977. vol.64.

ROQUE. Sebastião José. História do Direito. São Paulo: Ícone, 2007. 
RUI BARBOSA. Obras Completas de Rui Barbosa. Parecer sobre a redação do Código Civil. Rio de Janeiro: Oficina Gráfica do Departamento de Imprensa Nacional, 1949. vol.XXIX, Tomo I.

Obras Completas de Rui Barbosa. Relatório do Ministro da Fazenda. Rio de Janeiro: $\overline{\text { Oficina }}$ Gráfica do Departamento de Imprensa Nacional, 1949. vol.XVIII, Tomo II.

Obras Completas de Rui Barbosa. Parecer Jurídico. Rio de Janeiro: Oficina Gráfica do Departamento de Imprensa Nacional, 1968. vol.XXXII, Tomo III.

. Obras Completas de Rui Barbosa. Anexos ao Relatório do Ministro da Fazenda. Rio de Janeiro: Oficina Gráfica do Departamento de Imprensa Nacional, 1949. vol.XVIII, Tomo IV.

SÁ PEREIRA, Virgilio de. Direito das Cousas. Art. 524-678. In: LACERDA,Paulo de. Manual do Código Civil Brasileiro.Rio de Janeiro: Jacintho Ribeiro dos Santos, 1924.vol.VIII.

SANTOS, Sydney M.G. dos. André Rebouças e seu tempo. Rio de Janeiro: Vozes Ltda, 1985.

SEGURADO, Milton Duarte. O Direito no Brasil. São Paulo: José Bushatsky, 1972.

SERPA LOPES, Miguel Maria de. Tratado de Registros Públicos. Rio de Janeiro: Jacintho Ribeiro dos Santos, 1938. vol.I. vol.IV. . Tratado de Registros Públicos. Rio de Janeiro: Jacintho Ribeiro dos Santos, 1938. Tratado de Registros Públicos. $3^{\mathrm{a} e d ., ~ R i o ~ d e ~ J a n e i r o: ~ F r e i t a s ~ B a s t o s, ~ 1955 . ~ v o l . I I I . ~}$ 
SKIDMORE, Thomas E. Uma história do Brasil. São Paulo: Paz e Terra, 1998.

SORIANO DE SOUZA NETO, José. Publicidade Material do Registro Imobiliário: efeitos da transcrição. Recife: [s.n.], 1940.

SOUZA DINIZ. Código Napoleão ou Código Civil dos Franceses. Rio de Janeiro: Distribuidora Record, 1962.

TEIXEIRA DE FREITAS, Augusto. Consolidação das Leis Civis. Rio de Janeiro: Typographia Universal de Laemmert, 1865.

Esboço do Código Civil. Brasília: Fundação Universidade de Brasília, 1983. vol.I.

Esboço do Código Civil. Brasília: Fundação Universidade de Brasília, 1983. vol.2.

TRÍPOLI, César. História do Direito Brasileiro. São Paulo: Revista dos Tribunaes, 1947. vol.2.

VALLIM, João Rabello de Aguiar. Direito Imobiliário Brasileiro (doutrina e prática). São Paulo: Revista dos Tribunais, 1980.

VAMPRÉ, Spencer. Pareceres e Razões. Registro Torrens - Sua Inconstitucionalidade. [s.n.] 1922. vol.39.

VARELA, Laura Beck. Das Sesmarias à propriedade moderna: um estudo de história do direito brasileiro. Rio de Janeiro: Renovar, 2005. 
VEIGA, Didimo Agapito da. Direito Hypothecario commentario ao decreto $169-A$ de 19 de janeiro de 1890. Rio de Janeiro: Laemmert \& C., 1899. 